Prepared in cooperation with the U.S. Environmental Protection Agency

\title{
Water-Quality, Bed-Sediment, and Biological Data (October 2016 through September 2017) and Statistical Summaries of Data for Streams in the Clark Fork Basin, Montana
}

Open-File Report 2019-1060

U.S. Department of the Interior

U.S. Geological Survey 
Cover. The Little Blackfoot River entering the Clark Fork, just downstream from the sampling site Clark Fork above the Little Blackfoot River near Garrison, Montana. Photograph by Hannah Nilges, U.S. Geological Survey. 


\section{Water-Quality, Bed-Sediment, and \\ Biological Data (October 2016 through September 2017) and Statistical Summaries of Data for Streams in the Clark Fork Basin, Montana}

By Thomas E. Cleasby, Michelle I. Hornberger, Terry L. Heinert, and Matthew A. Turner

Prepared in cooperation with the U.S. Environmental Protection Agency

Open-File Report 2019-1060 


\title{
U.S. Department of the Interior DAVID BERNHARDT, Secretary
}

\author{
U.S. Geological Survey \\ James F. Reilly II, Director
}

U.S. Geological Survey, Reston, Virginia: 2019

For more information on the USGS - the Federal source for science about the Earth, its natural and living resources, natural hazards, and the environment-visit https://www.usgs.gov or call 1-888-ASK-USGS.

For an overview of USGS information products, including maps, imagery, and publications, visit https://store.usgs.gov.

Any use of trade, firm, or product names is for descriptive purposes only and does not imply endorsement by the U.S. Government.

Although this information product, for the most part, is in the public domain, it also may contain copyrighted materials as noted in the text. Permission to reproduce copyrighted items must be secured from the copyright owner.

Suggested citation:

Cleasby, T.E., Hornberger, M.I., Heinert, T.L., and Turner, M.A., 2019, Water-quality, bed-sediment, and biological data (October 2016 through September 2017) and statistical summaries of data for streams in the Clark Fork Basin, Montana: U.S. Geological Survey Open-File Report 2019-1060, 110 p., https://doi.org/10.3133/ofr20191060.

ISSN 2331-1258 (online) 


\section{Contents}

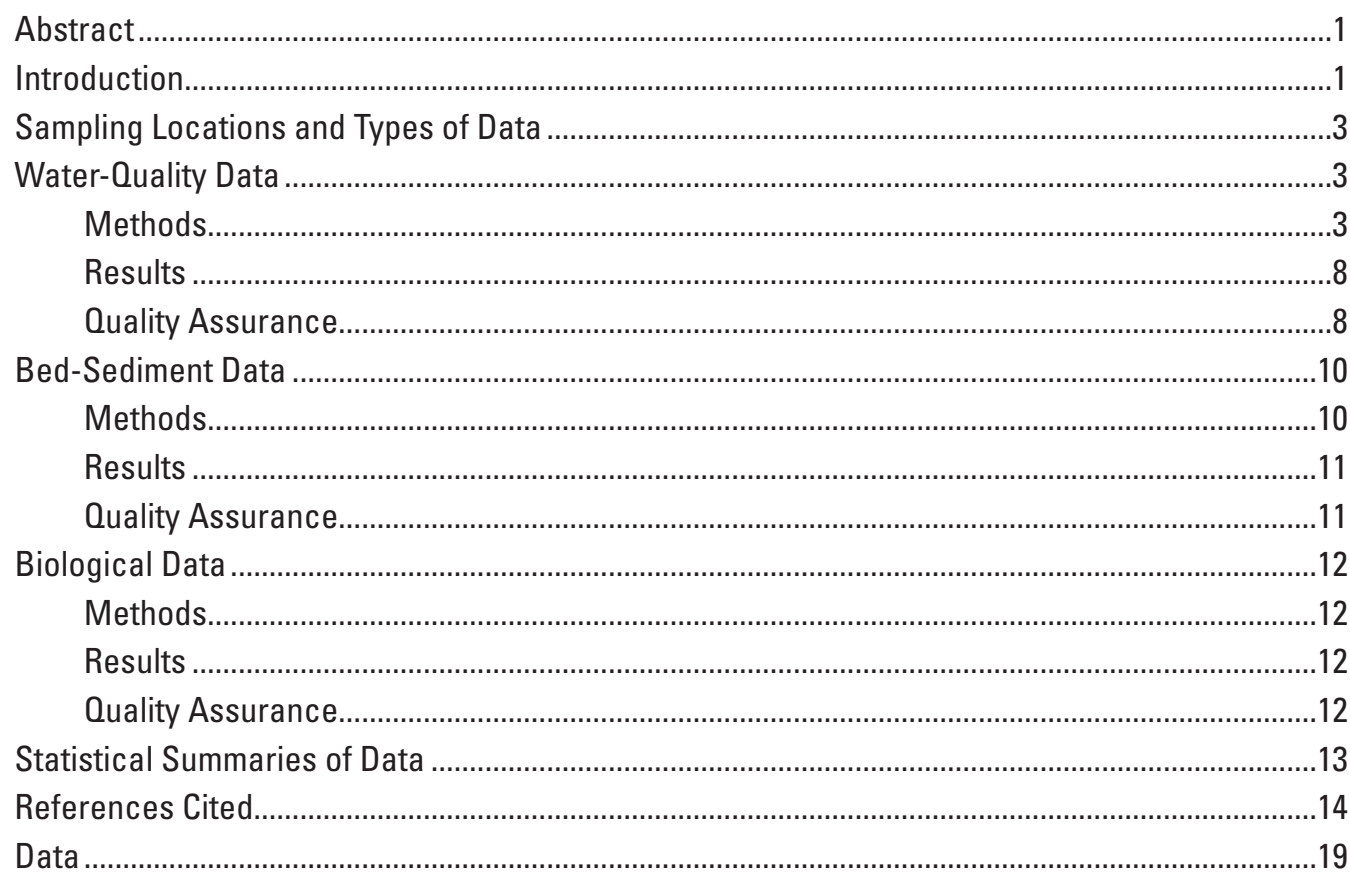

\section{Figure}

1. Map showing location of the study area in the Clark Fork Basin, Montana ....................2

\section{Tables}

1. Type and period of data collection at sampling sites in the Clark Fork Basin, Montana

2. Properties and constituents measured onsite or analyzed in water, bed-sediment, and biota samples from the Clark Fork Basin, Montana.....

3. Data-quality objectives for analyses of water samples collected in the Clark Fork Basin, Montana....

4. Water-quality data for the Clark Fork Basin, Montana, October 2016 through September 2017

5. Seasonal daily maximum, minimum, and mean turbidity, with monthly summary statistics, at Mill Creek at Opportunity, Montana, March through September 2017

6. Seasonal daily maximum, minimum, and mean turbidity, with monthly summary statistics, at Willow Creek at Opportunity, Montana, March through September 2017

7. Seasonal daily maximum, minimum, and mean turbidity, with monthly summary statistics, at Warm Springs Creek at Warm Springs, Montana, March through September 2017. 
8. Seasonal daily maximum, minimum, and mean turbidity, with monthly summary statistics, at Lost Creek near Anaconda, Montana, March through September 2017

9. Analyses of field replicates for water samples, Clark Fork Basin, Montana .48

10. Precision of analyses of field replicates for stream water samples, Clark Fork Basin, Montana.

11. Precision of analyses of laboratory replicates for stream water samples, Clark Fork Basin, Montana

12. Recovery efficiency for analyses of laboratory-spiked deionized-water blank samples

13. Recovery efficiency for analyses of laboratory-spiked stream samples, Clark Fork Basin, Montana

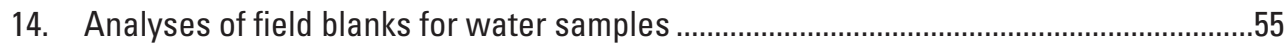

15. Bed-sediment data for the Clark Fork Basin, Montana, August 2017 …...........................56

16. Recovery efficiency for analyses of standard reference materials for bed-sediment samples....................................................................................................57

17. Analyses of procedural blanks for bed-sediment samples ........................................58

18. Biological data for the Clark Fork Basin, Montana, August 2017 .....................................59

19. Recovery efficiency for analyses of certified reference material for biota samples

20. Analyses of procedural blanks for biota samples

21. Statistical summary of long-term water-quality data for the Clark Fork Basin, Montana, March 1985 through September 2017

22. Statistical summary of long-term bed-sediment data for the Clark Fork Basin, Montana, August 1986 through August 2017

23. Statistical summary of long-term biological data for the Clark Fork Basin, Montana, August 1986 through August 2017.

\section{Conversion Factors}

U.S. customary units to International System of Units

\begin{tabular}{|c|c|c|}
\hline Multiply & By & To obtain \\
\hline \multicolumn{3}{|c|}{ Length } \\
\hline mile (mi) & 1.609 & kilometer (km) \\
\hline \multicolumn{3}{|c|}{ Area } \\
\hline square mile $\left(\mathrm{mi}^{2}\right)$ & 2.590 & square kilometer $\left(\mathrm{km}^{2}\right)$ \\
\hline
\end{tabular}

Temperature in degrees Celsius $\left({ }^{\circ} \mathrm{C}\right)$ may be converted to degrees Fahrenheit $\left({ }^{\circ} \mathrm{F}\right)$ as follows:

$$
{ }^{\circ} \mathrm{F}=\left(1.8 x^{\circ} \mathrm{C}\right)+32
$$




\section{Datum}

Horizontal coordinate information is referenced to the North American Datum of 1927 (NAD 27).

\section{Supplemental Information}

Concentrations of chemical constituents in water are given either in milligrams per liter $(\mathrm{mg} / \mathrm{L})$ or micrograms per liter $(\mu \mathrm{g} / \mathrm{L})$.

Pore size is given in micrometers $(\mu \mathrm{m})$.

Suspended-sediment sizes are given in millimeters $(\mathrm{mm})$ and weights are given in grams $(\mathrm{g})$.

Bottle capacities or liquid measurements are given in milliliters $(\mathrm{mL})$.

Liquid-phase trace-element concentrations are given in micrograms per milliliter $(\mu \mathrm{g} / \mathrm{mL})$, and solid-phase concentrations are given in micrograms per gram $(\mu \mathrm{g} / \mathrm{g})$.

A water year is the 12-month period from 0ctober 1 through September 30 and is designated by the calendar year in which it ends. For example, water year 2017 is the period from 0ctober 1 , 2016, through September 30, 2017.

\section{Abbreviations}

$\begin{array}{ll}\text { CRM } & \text { certified reference material } \\ \text { ICP-MS } & \text { inductively coupled plasma-mass spectrometry } \\ \text { LRL } & \text { laboratory reporting level } \\ \text { MRL } & \text { minimum reporting level } \\ \text { NIST } & \text { National Institute of Standards and Technology } \\ \text { NRP } & \text { National Research Program } \\ \text { NWIS } & \text { National Water Information System } \\ \text { NWOL } & \text { National Water Quality Laboratory } \\ \text { RSD } & \text { relative standard deviation } \\ \text { SPp. } & \text { species } \\ \text { SRM } & \text { standard reference material } \\ \text { USGS } & \text { U.S. Geological Survey }\end{array}$





\title{
Water-Quality, Bed-Sediment, and Biological Data (October 2016 through September 2017) and Statistical Summaries of Data for Streams in the Clark Fork Basin, Montana
}

\author{
By Thomas E. Cleasby, Michelle I. Hornberger, Terry L. Heinert, and Matthew A. Turner
}

Abstract

Water, bed sediment, and biota were sampled in selected streams from Butte to near Missoula, Montana, as part of a monitoring program in the Clark Fork Basin of western Montana. The sampling program was led by the U.S. Geological Survey, in cooperation with the U.S. Environmental Protection Agency, to characterize aquatic resources in the Clark Fork Basin and emphasize trace elements associated with historic mining and smelting activities. Sampling sites were on the Clark Fork and selected tributaries. Water samples were collected periodically at 20 sites from October 2016 through September 2017. Bed-sediment and biota samples were collected once at 13 sites during August 2017.

This report presents the analytical results and qualityassurance data for water-quality, bed-sediment, and biota samples collected at sites from October 2016 through September 2017. Water-quality data include concentrations of selected major ions, dissolved organic carbon, turbidity, nitrogen (nitrate plus nitrite), trace elements, and suspended sediment. Seasonal daily values of turbidity were determined at four sites. Bed-sediment data include trace-element concentrations in the fine-grained (less than 0.063 millimeter) fraction. Biological data include trace-element concentrations in wholebody tissue of aquatic benthic insects. Statistical summaries of water-quality, bed-sediment, and biological data for sites in the Clark Fork Basin are provided for the period of record.

\section{Introduction}

The Clark Fork originates near the town of Warm Springs in western Montana at the confluence of Silver Bow and Warm Springs Creeks (fig. 1). Along the 148-mile (mi) reach of stream from Silver Bow Creek in Butte to the Clark Fork near Missoula, six major tributaries enter: Blacktail Creek, Warm Springs Creek, Little Blackfoot River, Flint Creek, Rock Creek, and Blackfoot River. Principal surface-water uses in the 6,000-square-mile $\left(\mathrm{mi}^{2}\right)$ Clark Fork Basin above Missoula include irrigation, stock watering, small-scale industry (Cannon and Johnson, 2004), and habitat for trout fisheries. Current (as of 2018) land uses are primarily cattle production, logging, mining, residential development, and recreation. Large-scale mining and smelting were prevalent land uses in the basin for more than 100 years but are now either discontinued or substantially reduced in scale.

Copper, gold, silver, and lead ores were extensively mined, milled, and smelted in the drainages of Silver Bow and Warm Springs Creeks from about the 1860s to the 1980s (U.S. Environmental Protection Agency, 2004). Moderate- and small-scale mining also took place in the basins of most of the major tributaries to the upper Clark Fork. Tailings produced during past mineral processing commonly contained large quantities of trace elements such as arsenic, cadmium, copper, lead, and zinc. Eroded tailings mixed with stream sediment and deposited downstream in stream channels, on flood plains, in the Warm Springs Ponds, and at the former Milltown Reservoir (fig. 1; Andrews, 1987), whose dam (Milltown Dam, not shown in figure) was breached on March 28, 2008. The presence of elevated trace-element concentrations in water and bed sediment can pose a health risk to aquatic biota and humans (U.S. Environmental Protection Agency, 2004).

Concern about the toxicity of trace elements to aquatic biota and human health has resulted in a comprehensive effort by State, Federal, Tribal, and private entities to characterize the aquatic resources in the Clark Fork Basin. This effort was designed to guide and monitor remedial cleanup activities and to evaluate the effectiveness of remediation. Water-quality data have been collected by the U.S. Geological Survey (USGS) at selected sites in the Clark Fork Basin since 1985 (Lambing, 1987-1991; Lambing and others, 1994, 1995; Dodge and others, 1996-2010, 2012, 2013, 2014a, 2014b, 2017, 2018; Dodge and Hornberger, 2015). Trace-element data for bed sediment and biota (aquatic benthic insects) have been collected intermittently at selected sites since 1986 as part of studies on the contamination of bed-sediment quality and bioaccumulation of metals led by the USGS National Research Program 

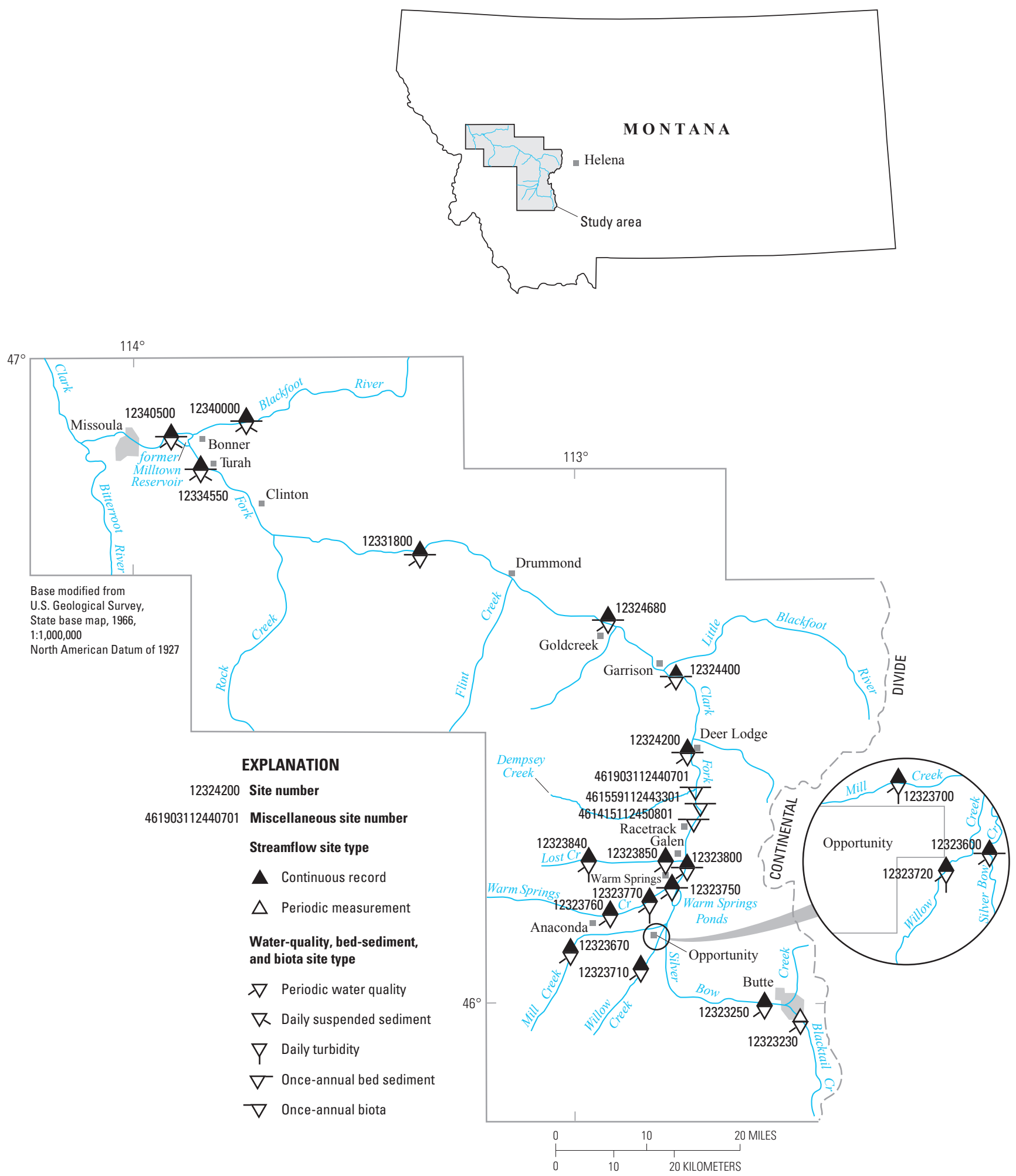

Figure 1. Location of the study area in the Clark Fork Basin, Montana. 
(NRP; Axtmann and Luoma, 1991; Cain and others, 1992, 1995; Axtmann and others, 1997; Hornberger and others, 1997). In March 1993, a long-term monitoring program for water, bed sediment, and biota in the basin was implemented by the USGS, in cooperation with the U.S. Environmental Protection Agency, to systematically quantify the seasonal and annual variability in selected constituents.

The purpose of this report is to present water-quality data from samples collected at 20 sites and bed-sediment and biological data from samples collected at 13 sites in the Clark Fork Basin from October 2016 through September 2017 (fig. 1). Quality-assurance data are presented for water-quality, bed-sediment, and biota samples collected during the same period. Statistical summaries also are provided for all data collected for the period of record.

\section{Sampling Locations and Types of Data}

Sampling sites for the monitoring program in the Clark Fork Basin from Butte to near Missoula (fig. 1) are on the Clark Fork main stem (including Silver Bow Creek), three major tributaries (Blacktail Creek, Warm Springs Creek, and Blackfoot River), and three smaller tributaries (Mill Creek, Willow Creek, and Lost Creek). The sites, types of data collected, and period of record for each data type are listed in table 1. Main-stem sampling sites were selected to divide the Clark Fork into reaches of approximate uniform length and to have each reach encompassing either a major tributary or depositional environment (that is, Warm Springs Ponds or the former Milltown Reservoir). Major tributaries were sampled to describe water-quality, bed-sediment, and biological characteristics of important hydrologic sources in the Clark Fork Basin and to provide reference comparisons to the main stem. The three smaller tributaries were sampled to gain better spatial resolution on sources of trace elements entering the Clark Fork in an area of historical metal-processing activities near Anaconda, Montana. Water-quality samples were collected at 20 sites, 6 to 8 times a year on a schedule designed to describe seasonal and hydrological variability. Seasonal daily turbidity values were computed using data measured by continuous turbidity monitors recording every 15 minutes at four sites. Bed-sediment and biological samples were collected annually at 13 sites, and 1 additional site (Warm Springs Creek at Warm Springs [12323770]) was sampled every 3 years. Continuous streamflow data were collected at 19 sites.

Properties measured onsite and constituents for which water, bed-sediment, and biota samples were analyzed are listed in table 2. Data-quality objectives for analyses of water samples are listed in table 3 . Results of onsite measurements of stream properties; laboratory analyses of water-quality, bed-sediment, and biota samples; and quality-assurance data for water year 2017 (October 1, 2016, through September 30, 2017) are listed in tables 4 through 23 at the back of the report. Statistical summaries of long-term water-quality, bed-sediment, and biological data collected between March 1985 and September 2017 are listed in tables 21 through 23 at the back of the report.

Quality assurance of data was maintained using documented procedures described in the following sections. These quality-assurance data were designed to provide environmentally representative data. Acceptable results of the procedures were verified with quality-control samples that were collected systematically to provide a measure of the accuracy, precision, and bias of the environmental data and to identify problems associated with sampling, processing, or analysis.

\section{Water-Quality Data}

Water-quality data consist of onsite measurements of selected stream properties and laboratory determination of concentrations of chemical and physical constituents (listed in table 2) in periodically collected stream samples. Water samples were collected at 20 sites in the Clark Fork Basin 6 to 8 times per year on a schedule designed to describe seasonal and hydrologic variability. Continuous turbidity monitors were operated seasonally (March to September 2017) at four sites; turbidity data (recorded every 15 minutes) were used to compute daily mean turbidity values (table 1). Water-quality data are available through the USGS National Water Information System (NWIS) database at https://waterdata.usgs.gov/nwis/ qw (U.S. Geological Survey, 2018).

\section{Methods}

Water samples were collected and composited from vertical transits throughout the entire stream depth at multiple locations across the stream using depth- and width-integration methods described by Ward and Harr (1990), Edwards and Glysson (1999), and the U.S. Geological Survey (variously dated). These methods provided vertically and laterally discharge-weighted composite samples that represent the entire flow passing through the cross section of the stream. Samples were collected with isokinetic depth-integrating water-quality samplers (Davis and the Federal Interagency Sedimentation Project, 2005) constructed of plastic or coated with a nonmetallic rubber-coating paint and equipped with polytetrafluoroethylene nozzles.

Instantaneous streamflow was determined at the time of water sampling either by direct measurement or from stagedischarge rating tables (Rantz and others, 1982). Daily mean streamflow values during ice periods were labeled as estimated because backwater affected the stage-discharge relation. Onsite measurements of $\mathrm{pH}$, specific conductance, and water temperature were measured during water sample collection. Sample processing, including filtration and preservation, was completed according to procedures described by Ward and Harr (1990), Horowitz and others (1994), and the U.S. Geological Survey (variously dated). 


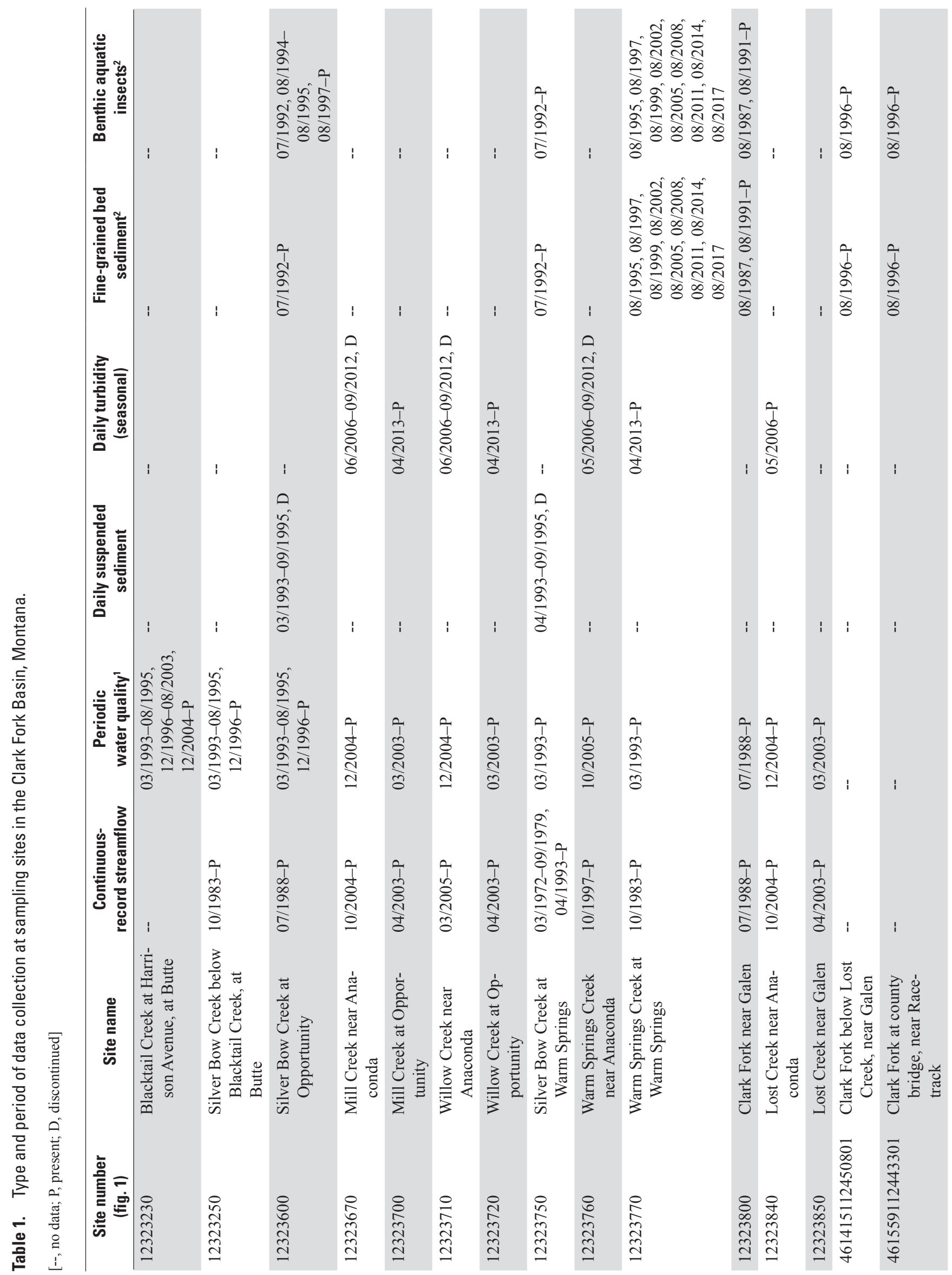




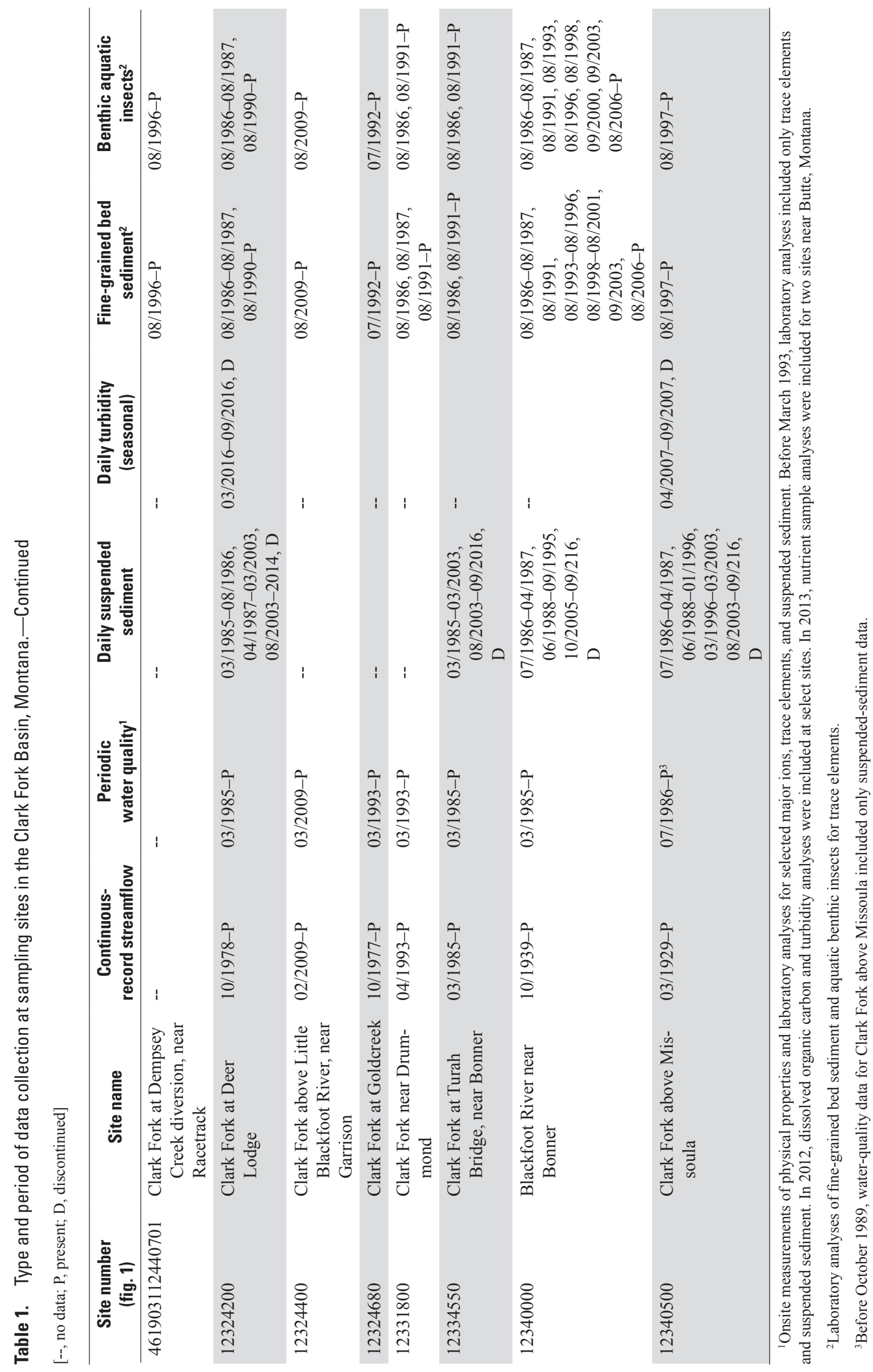


Table 2. Properties and constituents measured onsite or analyzed in water, bed-sediment, and biota samples from the Clark Fork Basin, Montana.

\begin{tabular}{|c|c|c|c|}
\hline \multicolumn{2}{|c|}{ Water } & \multirow{2}{*}{$\begin{array}{c}\text { Bed sediment } \\
\text { Constituent }\end{array}$} & \multirow{2}{*}{$\begin{array}{c}\text { Benthic aquatic insects } \\
\text { Constituent }\end{array}$} \\
\hline Property & Constituent & & \\
\hline Streamflow & Hardness (calculated) & Arsenic & Arsenic \\
\hline $\mathrm{pH}$ & Calcium & Cadmium & Cadmium \\
\hline Specific conductance & Magnesium & Chromium & Chromium \\
\hline Temperature & Potassium & Copper & Copper \\
\hline \multirow[t]{16}{*}{ Turbidity } & Sodium & Iron & Iron \\
\hline & Alkalinity & Lead & Lead \\
\hline & Chloride & Manganese & Manganese \\
\hline & Fluoride & Nickel & Nickel \\
\hline & Silica & Zinc & Zinc \\
\hline & Sulfate & & \\
\hline & Nitrate plus nitrite & & \\
\hline & Cadmium & & \\
\hline & Copper & & \\
\hline & Iron & & \\
\hline & Lead & & \\
\hline & Manganese & & \\
\hline & Zinc & & \\
\hline & Arsenic & & \\
\hline & Dissolved organic carbon & & \\
\hline & Suspended sediment & & \\
\hline
\end{tabular}

Concentrations of arsenic, cadmium, copper, lead, manganese, and zinc in filtered samples $(0.45$-micrometer $[\mu \mathrm{m}]$ pore size) were measured using inductively coupled plasmamass spectrometry (ICP-MS; Garbarino and others, 2006). Concentrations of calcium, magnesium, and iron in filtered samples were measured using inductively coupled plasmaatomic emission spectrometry (Fishman and Friedman, 1989). Calcium and magnesium concentrations were used to calculate water hardness. Concentrations of potassium, sodium, alkalinity, chloride, fluoride, silica, sulfate, nitrogen (nitrate plus nitrite), and dissolved organic carbon were measured in filtered samples collected at select sites in the upper Clark Fork Basin. Potassium was measured by Standard Method 3120 (American Public Health Association, 1998); sodium and silica were analyzed by inductively coupled plasmaatomic emission spectrometry (Fishman, 1993); alkalinity was measured by electrometric titration (Fishman and Friedman, 1989); chloride, fluoride, and sulfate were measured by ion chromatography (Fishman and Friedman, 1989); nitrogen (nitrate plus nitrite) was measured by colorimetric enzymatic reduction (Patton and Kryskalla, 2011); and dissolved organic carbon was measured by persulfate oxidation and infrared spectrometry (Brenton and Arnett, 1993). Recoverable concentrations of trace elements were measured in unfiltered samples that were first digested with dilute hydrochloric acid (Hoffman and others, 1996). For cadmium, iron, lead, and manganese, the digested samples were analyzed by ICP-MS as described by Garbarino and Struzeski (1998). For arsenic, copper, and zinc, the digested samples were analyzed by ICP-MS as described by Garbarino and others (2006). Turbidity was measured using Standard Method 2130 (American Public Health Association, 1998) in selected unfiltered samples. All samples were analyzed at the USGS National Water Quality Laboratory (NWQL) in Denver, Colorado.

Water samples for analysis of suspended sediment also were collected from multiple vertical transits when periodic water samples were collected. Water samples were analyzed for suspended-sediment concentration and the percentage of suspended-sediment mass finer than 0.062-millimeter (mm) diameter (silt size and smaller) by the USGS WyomingMontana Water Science Center Sediment Laboratory (hereinafter referred to as the "Wyoming-Montana Sediment Laboratory") in Helena, Mont., according to methods described by Guy (1969) and Dodge and Lambing (2006). 
Table 3. Data-quality objectives for analyses of water samples collected in the Clark Fork Basin, Montana.

[lab, laboratory; NTRU, nephelometric turbidity ratio unit; --, not determined; mg/L, milligram per liter; $\mu \mathrm{g} / \mathrm{L}$, microgram per liter; mm, millimeter]

\begin{tabular}{|c|c|c|c|}
\hline \multirow[b]{3}{*}{ Constituent } & \multicolumn{3}{|c|}{ Data-quality objectives } \\
\hline & Detectability & Precision & Bias \\
\hline & $\begin{array}{l}\text { Laboratory } \\
\text { reporting } \\
\text { level }\end{array}$ & $\begin{array}{l}\text { Maximum relative standard } \\
\text { deviation of replicate analyses } \\
\text { (percent) }\end{array}$ & $\begin{array}{l}\text { Maximum deviation of spike } \\
\text { recovery (percent) }\end{array}$ \\
\hline Turbidity, unfiltered, lab, NTRU & 2.0 units & 20 & -- \\
\hline Calcium, filtered & $0.022 \mathrm{mg} / \mathrm{L}$ & 20 & -- \\
\hline Magnesium, filtered & $0.011 \mathrm{mg} / \mathrm{L}$ & 20 & -- \\
\hline Potassium, filtered & $0.03-0.1 \mathrm{mg} / \mathrm{L}$ & 20 & -- \\
\hline Sodium, filtered & $0.06-0.1 \mathrm{mg} / \mathrm{L}$ & 20 & -- \\
\hline Alkalinity, filtered, lab & $4.0 \mathrm{mg} / \mathrm{L}$ & 20 & -- \\
\hline Chloride, filtered & $0.02 \mathrm{mg} / \mathrm{L}$ & 20 & -- \\
\hline Fluoride, filtered & $0.01 \mathrm{mg} / \mathrm{L}$ & 20 & -- \\
\hline Silica, filtered & $0.018 \mathrm{mg} / \mathrm{L}$ & 20 & -- \\
\hline Sulfate, filtered & $0.02 \mathrm{mg} / \mathrm{L}$ & 20 & -- \\
\hline Nitrate plus nitrite, filtered & $0.01 \mathrm{mg} / \mathrm{L}$ & 20 & -- \\
\hline Cadmium, filtered & $0.03 \mu \mathrm{g} / \mathrm{L}$ & 20 & 25 \\
\hline Cadmium, unfiltered recoverable & $0.03 \mu \mathrm{g} / \mathrm{L}$ & 20 & 25 \\
\hline Copper, filtered & $0.2 \mu \mathrm{g} / \mathrm{L}$ & 20 & 25 \\
\hline Copper, unfiltered recoverable & $0.2 \mu \mathrm{g} / \mathrm{L}$ & 20 & 25 \\
\hline Iron, filtered & $4-10 \mu \mathrm{g} / \mathrm{L}$ & 20 & 25 \\
\hline Iron, unfiltered recoverable & $4.6-10 \mu \mathrm{g} / \mathrm{L}$ & 20 & 25 \\
\hline Lead, filtered & $0.02 \mu \mathrm{g} / \mathrm{L}$ & 20 & 25 \\
\hline Lead, unfiltered recoverable & $0.02 \mu \mathrm{g} / \mathrm{L}$ & 20 & 25 \\
\hline Manganese, filtered & $0.4 \mu \mathrm{g} / \mathrm{L}$ & 20 & 25 \\
\hline Manganese, unfiltered recoverable & $0.4 \mu \mathrm{g} / \mathrm{L}$ & 20 & 25 \\
\hline Zinc, filtered & $2 \mu \mathrm{g} / \mathrm{L}$ & 20 & 25 \\
\hline Zinc, unfiltered recoverable & $2 \mu \mathrm{g} / \mathrm{L}$ & 20 & 25 \\
\hline Arsenic, filtered & $0.05 \mu \mathrm{g} / \mathrm{L}$ & 20 & 25 \\
\hline Arsenic, unfiltered recoverable & $0.05 \mu \mathrm{g} / \mathrm{L}$ & 20 & 25 \\
\hline Organic carbon, filtered & $0.23 \mathrm{mg} / \mathrm{L}$ & 20 & -- \\
\hline Sediment, suspended, percent finer than $0.062 \mathrm{~mm}$ & 1 percent & 20 & -- \\
\hline Sediment, suspended & $1 \mathrm{mg} / \mathrm{L}$ & 20 & -- \\
\hline
\end{tabular}

Real-time turbidity was measured from early spring (after ice breakup) to early fall (before stream freezeup) using model 6136 turbidity sensors (Yellow Springs Instruments, Yellow Springs, Ohio) at four tributary sites in the upper Clark Fork Basin near Anaconda (table 1). Turbidity values were recorded every 15 minutes and are stored in the USGS NWIS database (U.S. Geological Survey, 2018) at https://waterdata.usgs.gov/mt/nwis/current?type=quality. The in situ values differ from the results of laboratory-measured turbidity in discrete water-quality samples because of differences in the instrumentation and sampling procedures. Continuous recordings enable determination of the minimum and maximum turbidity values for each day as well as a daily mean turbidity, which is based on the average of all values in a 24-hour period. Procedures for the operation of continuous turbidity monitors and for daily record computations are described by Wagner and others (2006). 


\section{Results}

Water-quality data from samples collected periodically during water year 2017 (October 1, 2016, through September 30,2017 ) are listed in table 4 . In water year 2017 , there was one water-quality sample at Mill Creek near Anaconda (12323670) on April 17, 2017, with missing values for filtered and unfiltered copper. These copper values did not pass review because the filtered value was greater than the unfiltered value, and this issue could not be resolved by reruns. Daily maximum, minimum, and mean turbidity at four sites are listed in tables 5 through 8 along with monthly summary statistics. Water-quality data are available in the USGS NWIS database (U.S. Geological Survey, 2018).

\section{Quality Assurance}

Quality-assurance procedures used for the collection and field processing of water samples were described by Ward and Harr (1990), Horowitz and others (1994), Edwards and Glysson (1999), Lambing (2006), and the U.S. Geological Survey (variously dated). Standard procedures used by the NWQL for internal sample handling and quality assurance were described by Friedman and Erdmann (1982), Jones (1987), and Pritt and Raese (1995). Quality-assurance procedures used by the Wyoming-Montana Sediment Laboratory were described by Dodge and Lambing (2006). Standard procedures used for the calibration, measurement, and quality assurance of turbidity monitors were described by Anderson (2005).

The quality of analytical results reported for water samples was evaluated using quality-control samples that were sampled and analyzed concurrently with primary environmental samples. These quality-control samples consisted of replicates, spikes, and blanks that provided quantitative information on the precision and bias of the overall field and laboratory processes. Each type of quality-control sample was submitted at a proportion equivalent to about 5 percent of the total number of water samples; therefore, the total number of quality-control samples represented about 15 percent of the total number of water samples.

Replicate data can be collected in different ways to provide an assessment of the precision (reproducibility) of analytical results. Replicate samples are two or more samples considered to be essentially identical in composition. Replicate samples can be collected in the field (field replicate) either by repeating the collection process (sequential or concurrent replicate) to obtain two or more independent composite samples or by splitting a single composite sample into two or more subsamples (split replicate). The individual replicate samples are then analyzed separately. Likewise, a single sample can be analyzed two or more times in the laboratory to obtain a measure of analytical precision (laboratory replicate).

Precision of analytical results for field replicates can be affected by numerous sources of variability within the field and laboratory environments, including sample collection, processing, and analysis. Data on overall precision for samples exposed to field and laboratory sources of variability were provided by obtaining replicate stream samples for chemical analysis by splitting a composite stream sample. Replicate stream samples for suspended-sediment analysis were obtained in the field by collecting two independent cross-sectional samples. Analyses of field replicate samples indicate the reproducibility of environmental data that are affected by the combined potential variability introduced by field and laboratory processes.

In addition to analyzing quality-control samples submitted from the field, internal quality-assurance practices are performed systematically by the NWQL to provide quality control of analytical procedures (D.L. Stevenson, U.S. Geological Survey, written commun., 2012). These internal practices include analyses of quality-control samples such as calibration standard samples, standard reference water samples, replicate samples, deionized-water blank samples, or spiked samples at a proportion equivalent to at least 10 percent of the sample load. The NWQL participates in a blind-sample program in which standard reference water samples prepared by the USGS Branch of Quality Systems are routinely inserted into the sample line for each analytical method at a frequency proportional to the sample load. The laboratory also participates in external evaluation studies and audits with the National Environmental Laboratory Accreditation Program, the U.S. Environmental Protection Agency, Environment Canada, and the USGS Branch of Quality Systems to assess analytical performance.

Precision of analytical results for laboratory replicates, which exclude field sources of variability, was determined using two independent chemical analyses of aliquots from a single sample selected from the group of samples constituting each analytical run. A separate analysis of the sample was made at the beginning and end of each analytical run to provide information on the reproducibility of laboratory analytical results independent of variability caused by field sample collection and processing. Laboratory replicates of suspendedsediment samples were not obtainable because the samples were consumed during the analysis.

Spiked samples (Boughton, 2019) were used to evaluate bias, which measures the ability of an analytical method to accurately quantify a known amount of analyte added to a sample. In the laboratory, deionized-water blank samples and aliquots of stream samples were spiked with known amounts of the same trace elements for which water samples were being analyzed. Analyses of spiked blanks indicate if the spiking procedure and analytical method are within control for water that is presumably free of chemical interference. Analyses of spiked aliquots of stream samples indicate if the chemical matrix of the stream water interferes with the analytical measurement and if these interferences could contribute substantial bias to reported trace-element concentrations for stream samples.

Field blank samples were submitted for every field trip and analyzed to identify the presence and magnitude of contamination that could potentially bias analytical results. Field 
blanks consist of deionized water that is certified as constituent free and is processed in the field through clean sampling equipment used to collect stream samples. These blanks then are subjected to the same processing (sample splitting, filtration, preservation, transportation, and laboratory handling) as stream samples. Blank samples are analyzed for the same constituents as stream samples to detect contamination.

All water samples were handled in accordance with chain-of-custody procedures that provide documentation of sample identity, shipment, receipt, and laboratory handling (Driscoll and Hatcher, 2010). All environmental and qualitycontrol samples submitted from a sampling episode were stored in a secure area of the NWQL and analyzed as a discrete sample group, independent of other samples submitted to the NWQL. Therefore, the quality-control data apply solely to the analytical results for stream samples reported herein and provide a direct measure of data quality for this study.

Data-quality objectives (table 3 ) were established by the USGS and U.S. Environmental Protection Agency as part of the study plan for the expanded long-term monitoring program started in 1993. The objectives identify the analytical requirements of detectability and serve as a guide for identifying questionable data by establishing acceptable limits for precision and bias of laboratory results. Comparisons of qualitycontrol data to data-quality objectives were used to evaluate if sampling and analytical procedures produced environmentally representative data in a consistent manner. Data that did not meet the objectives were evaluated for acceptability; if necessary, additional quality-control samples were submitted and corrective action was taken.

The precision of analytical results was determined by calculating the standard deviation of the differences in concentrations between replicate analyses. These replicate analyses consisted of pairs of field replicate samples and laboratory replicates. Standard deviations were calculated according to the following equation (Taylor, 1987):

$$
S=\sqrt{\frac{\Sigma^{d^{2}}}{2 k}}
$$

where

$$
\begin{aligned}
& S \quad \text { is the standard deviation of the difference in } \\
& \text { concentration between replicate analyses, } \\
& d \quad \text { is the difference in concentration between } \\
& \text { each pair of replicate analyses, and } \\
& k \quad \text { is the number of pairs of replicate analyses. }
\end{aligned}
$$

Precision also was expressed as a relative standard deviation (RSD), in percent, which was computed from the standard deviation and the mean concentration for all the replicate analyses. Expressing precision relative to a mean concentration standardized the comparison of precision among individual constituents. The RSD was calculated according to the following equation (Taylor, 1987):

$$
R S D=\frac{S}{\bar{x}} \times 100
$$

where

$$
\begin{aligned}
& R S D \text { is the relative standard deviation, } \\
& S \text { is the standard deviation, and } \\
& \bar{x} \text { is the mean concentration for all replicate } \\
& \text { analyses. }
\end{aligned}
$$

Sample results and the corresponding field replicate data are listed in table 9, and the precision for each constituent estimated from field replicate analyses is listed in table 10. Precision estimates for the analytical results of field replicates were within the acceptable RSD limit of 20 percent for all constituents except filtered cadmium (table 10), which was 21 percent. This one exceedance of the data-quality objective resulted from a statistical artifact of calculating the difference between one replicate sample pair for which one value is less than the laboratory reporting level (LRL).

The precision for each constituent estimated from laboratory replicate analyses is listed in table 11. Statistics summarizing the precision of analytical results for laboratory replicates were calculated using unrounded values stored in laboratory data files. Precision estimates for the laboratory replicates were within the acceptable 20-percent RSD limit for all constituents (table 11), so no adjustments were made to analytical data based on replicate analyses precision. Recovery efficiencies for analyses of constituents was determined by comparing a sample and a spiked aliquot of the same sample. The data-quality objective for acceptable spike recoveries of trace elements in water samples was a maximum deviation of 25 percent from a theoretical 100-percent recovery of an added constituent (table 3). At NWQL, a spiked deionizedwater blank sample and a spiked aliquot of a stream sample were prepared and analyzed along with the original unspiked sample. The differences between the spiked and unspiked sample concentrations were determined and used to compute recovery, in percent, according to equation 3 :

$$
R=\frac{D}{C} \times 100
$$

where

$$
\begin{aligned}
& R \quad \text { is the spike recovery, in percent; } \\
& D \quad \text { is the difference between the spiked and } \\
& \text { unspiked sample concentrations; and } \\
& C \quad \text { is the concentration of material used to spike } \\
& \text { the sample. }
\end{aligned}
$$

If the spike recovery of a trace element was outside a range of 75 to 125 percent, the instrument was recalibrated and the entire sample set and all spiked samples were reanalyzed for that element until recoveries were improved to the extent possible. Recovery efficiency for individual trace elements in 
spiked blank samples and in spiked stream samples is listed in tables 12 and 13, respectively. The mean recovery for spiked blank samples (table 12) ranged from 81.5 to 108 percent. The smallest individual constituent recovery was lead, filtered, at 53.4 percent, and the largest was cadmium, filtered, at 122 percent. The 95-percent confidence intervals (Taylor, 1987) for the mean recovery for each constituent for which spiked blank samples were analyzed (table 12) did not exceed a 25-percent deviation from an expected 100-percent recovery except for lead, filtered (53.4 percent). The mean recovery for spiked stream samples (table 13) ranged from 85.9 to 106 percent. The smallest constituent recovery was arsenic, unfiltered recoverable, at 43.4 percent, and the largest was arsenic, unfiltered recoverable, at 128 percent. The 95 -percent confidence intervals for the mean spike recovery for each constituent for which stream water samples were analyzed (table 13) did not exceed a 25-percent deviation from an expected 100-percent recovery except for arsenic, filtered (63.9 percent) and arsenic, unfiltered recoverable (43.4 and 128 percent). No adjustments were made to analytical data based on the mean spike recovery.

High or low bias is indicated if the 95-percent confidence interval does not include 100-percent recovery, thereby indicating a consistent deviation or bias, either high or low. Confidence intervals for percent recovery include 100 percent for all laboratory-spiked blank samples (table 12). Confidence intervals for percent recovery include 100 percent for all laboratory-spiked stream samples (table 13) except for iron, filtered (96.6-99.8 percent) and iron, unfiltered recoverable (79.3-96.3 percent). No adjustments were made to analytical results for stream samples based on spike recoveries.

Analytical results for field blanks are listed in table 14. Field blanks with constituent concentrations less than or equal to the LRL indicate that the entire process of sample collection, field processing, and laboratory analysis is presumably free of contamination. If detectable concentrations of trace elements in field blanks were greater than or equal to twice the LRL, the concentrations were noted during data review. Analytical results from the field blank were evaluated for evidence of a consistent trend that could indicate systematic contamination. Sporadic, infrequent, nonconsecutive exceedances of twice the LRL most likely represented random contamination or laboratory-instrument calibration error that was not persistent in the process and was not likely to cause positive bias in a long-term record of analytical results; however, if concentrations for a particular constituent exceeded twice the LRL in field blanks from two consecutive field trips, additional blank samples were collected and submitted for analysis to identify the source of contamination.

Constituent concentrations in field blanks (table 14) almost always were less than the LRL. Three sample concentrations of copper, filtered $(0.22,0.21$, and 0.26 micrograms per liter $[\mu \mathrm{g} / \mathrm{L}]$ ) exceeded the LRL of $0.20 \mu \mathrm{g} / \mathrm{L}$. One sample concentration of copper, unfiltered recoverable $(0.2 \mu \mathrm{g} / \mathrm{L})$ matched the LRL of $0.2 \mu \mathrm{g} / \mathrm{L}$. No adjustments were made to water-quality sample data based on a review of these results.

\section{Bed-Sediment Data}

Bed-sediment data for the long-term monitoring program in the Clark Fork Basin consist of trace-element concentrations in the fine-grained (less than $0.063 \mathrm{~mm}$ ) fraction of bedsediment samples. Bed-sediment samples were collected once annually at 13 sites (fig. 1; table 1) during low, stable flow conditions at about the same time of year as previous samples (typically in August) to facilitate data comparisons among years. Warm Springs Creek at Warm Springs is sampled once every 3 years rather than once annually and was sampled during water year 2017. The 2017 bed-sediment data are available in a machine-readable data release (Boughton, 2019). For prior years, bed-sediment data can be obtained in a Microsoft Excel format from the authors.

\section{Methods}

Fine-grained bed-sediment samples were collected in August 2017 using protocols described by Axtmann and Luoma (1991). Samples were collected from the surfaces of streambed deposits in areas near the edge of the stream using an acid-washed polypropylene scoop. Whenever possible, samples were collected from both sides of the stream.

Individual samples of bed sediment were collected by scooping material from the surfaces of three to five randomly selected deposits along pools or low-velocity areas. The three to five individual samples were combined to form a single composite sample. This collection process was repeated three times to obtain three composite samples. Each composite sample was wet sieved onsite through a $0.063-\mathrm{mm}$ polyester-mesh sieve using ambient stream water. The fraction of bed sediment in each composite sample that was finer than $0.063 \mathrm{~mm}$ was collected in an acid-washed 500-milliliter $(\mathrm{mL})$ polyethylene bottle and transported to the laboratory on ice.

Bed-sediment samples were processed and analyzed at the USGS NRP Ecology and Contaminants Project Laboratory in Menlo Park, California. Bed-sediment samples were ovendried at 60 degrees Celsius $\left({ }^{\circ} \mathrm{C}\right)$ and ground into smaller particle sizes using an acid-washed, ceramic mortar and pestle. Single aliquots of about 0.5-0.6 gram (g) of sediment from each of the three composite bed-sediment samples were digested using a hot, concentrated nitric acid reflux according to methods described by Luoma and Bryan (1981). Laboratory replicates were analyzed by taking an aliquot from one of the three sieved replicate samples at each site. After a 2-week digestion period, the aliquots were evaporated to dryness on a hot plate. The dry residue was reconstituted in $10 \mathrm{~mL}$ of $0.6 \mathrm{~N}$ (normal) hydrochloric acid. The reconstituted aliquots were then filtered through a $0.45-\mu \mathrm{m}$ pore-size filter using a syringe and an in-line disposable filter cartridge. The filtrate was diluted to a $1-10$ ratio with $0.6 \mathrm{~N}$ hydrochloric acid. These final solutions were analyzed for arsenic, cadmium, chromium, copper, iron, lead, manganese, nickel, and zinc using inductively coupled plasma-optical emission spectrometry 
(Hornberger and others, 1997). The smallest concentration of a constituent that can be reliably reported for analyses of bed sediment is termed the minimum reporting level (MRL).

\section{Results}

Solid-phase concentrations of trace elements measured in samples of fine-grained bed sediment collected during August 2017 are listed in table 15. Liquid-phase concentrations, measured in micrograms per milliliter, were analyzed in the reconstituted aliquots of digested bed sediment. Solid-phase concentrations, measured in micrograms per gram, were calculated using the following equation:

$\mu \mathrm{g} / \mathrm{g}=\frac{(\mu \mathrm{g} / \mathrm{mL})(\text { volume of digested sample, } \text { in } \mathrm{mL})}{(\text { dry weight of sample, in grams })(\text { dilution ratio })}$

where

$\mu \mathrm{g} / \mathrm{g} \quad$ is micrograms of trace element per gram, $\mu \mathrm{g} / \mathrm{mL} \quad$ is micrograms per milliliter of liquid-phase trace element, and

$\mathrm{mL} \quad$ is milliliters.

The reported solid-phase concentrations (table 15) are the means of all analyses for replicate aliquots from each composite bed-sediment sample collected at the site. Because the conversion from liquid-phase to solid-phase concentration is dependent on the dilution ratio and the dry weight of the sample, MRLs for some trace elements might differ among sites and among years.

\section{Quality Assurance}

The USGS protocols for field collection and processing of bed-sediment samples are designed to prevent contamination from metal sources. Nonmetallic sampling and processing equipment (white plastic scoop, funnel-frame apparatus, and $500-\mathrm{mL}$ sample bottles) were acid-washed and rinsed with deionized water before the collection of the first sample. Polyester-mesh sieves were washed in laboratory-grade detergent and rinsed with deionized water. All equipment received a field rinse onsite with stream water. Sampling equipment used at more than one site was field rinsed thoroughly between sites with site-specific stream water. Separate sieves were used at each site and, therefore, did not require between-site cleaning. Bed-sediment samples were collected sequentially at sites along a general increasing concentration gradient (that is, downstream sites have lower concentrations of contaminated bed sediments compared to upstream sites) to minimize effects from potential site-to-site carryover contamination (Axtmann and Luoma, 1991).

Quality assurance of analytical results for bed-sediment samples included laboratory-instrument calibration with standard solutions and analysis of quality-control samples designed to identify the presence and magnitude of bias (Ellen V. Axtmann, U.S. Geological Survey, written commun., 1994).
Quality-control samples consisted of standard reference materials (SRMs) issued by the National Institute of Standards and Technology (NIST) and procedural blanks. In total, 10 low-concentration SRMs, 10 high-concentration SRMs, and 13 procedural blanks were analyzed.

SRMs are commercially prepared materials that have certified concentrations of trace elements. Analyses of SRMs are used to indicate the ability of the method to accurately measure a known quantity of a constituent. Multiple analyses of SRMs are made to derive a mean and 95-percent confidence interval for recovery. Recovery efficiency for trace-element analyses of SRMs for bed sediment is listed in table 16. Two SRMs, consisting of agricultural soils and representing low and high concentrations of trace elements, were analyzed to test recovery efficiency for a range of concentrations like those discovered in the bed sediment in streams in the upper Clark Fork Basin.

The digestion process used to analyze bed-sediment samples is not a "total" digestion (does not liberate elements associated with crystalline lattices); therefore, 100-percent recovery may not be achieved for elements strongly bound to the sediment. The percent recovery of trace elements for SRM analyses that use less than a total digestion is useful to indicate which trace elements display strong sediment-binding characteristics in the SRM and if analytical recovery is consistent between multiple sets of analyses.

Although data-quality objectives have not been established for bed sediment, percent recoveries for individual trace elements (table 16) illustrate analytical performance. Metal recoveries of sediment digests were evaluated with NIST 2709a San Joaquin soils (hereinafter referred to as "SRM sample 2709A") and NIST 2711a Montana soil II (hereinafter referred to as "SRM sample 2711a"). Mean recoveries in SRM sample 2709a ranged from 45.0 to 90.0 percent of the certified concentrations (table 16). The mean recoveries were within 22 percent of the 95 -percent confidence interval for copper, iron, manganese, nickel, and zinc. Elements with low certified concentrations (cadmium, $0.371 \mu \mathrm{g} / \mathrm{g}$ ) or with a strong association with crystalline lattices (arsenic, chromium, lead) had lower percent recoveries (from 45.0 to 67.6 percent). Mean recoveries in SRM sample 2711a ranged from 55.6 to 97.7 percent (table 16). The percent recoveries were within 15.2 percent of the 95-percent confidence interval for arsenic, cadmium, copper, iron, lead, nickel, and zinc; and 19.1 percent for manganese. Chromium had the lowest mean recovery (55.6 percent) because of the strong binding nature of the crystalline lattice of chromium-bearing minerals. No adjustments were made to trace-element concentrations in bed-sediment samples based on recovery efficiencies.

Procedural blanks for bed-sediment samples consisted of the analysis of the same reagents used for sample digestion and reconstitution. Concentrated nitric acid used for sample digestion was heated and evaporated to dryness. After evaporation, $0.6 \mathrm{~N}$ hydrochloric acid was added to reconstitute the dry residue. Analytical results of procedural blanks for bed sediment (table 17) are reported as a liquid-phase 
concentration, in micrograms per milliliter. A procedural blank was prepared and analyzed concurrently with bed-sediment samples for each site. Concentrations of trace elements in all procedural blanks were less than the MRL for all elements. No adjustments were made to analytical data based on procedural blanks.

\section{Biological Data}

Biological data for the long-term monitoring program in the Clark Fork Basin consist of trace-element concentrations in the whole-body tissue of aquatic benthic insects. Insect samples are collected once annually at the same 13 sites and on the same dates as bed-sediment samples (fig. 1; table 1), 10 of which have streamgages, allowing for a direct comparison of biological data with bed-sediment data and water-quality data through the years. Warm Springs Creek at Warm Springs is sampled once every 3 years rather than once annually and was sampled during water year 2017. Biological data for water year 2017 are available in a machine-readable data release (Boughton, 2019). Biological data for prior years are available by request in Microsoft Excel format from the authors.

\section{Methods}

Insect samples were collected using protocols described in Hornberger and others (1997). Benthic insects at immature stages were collected with a large nylon-mesh kick net. A single riffle at each site was sampled repeatedly until an adequate number of individual insects were collected to provide sufficient mass for analysis (for example, about 10 stoneflies, about 100-200 caddisflies). Two caddisfly species of the genus Hydropsyche (Hydropsyche cockerelli and Hydropsyche occidentalis) were targeted for collection in this study because of their occurrence at most sites. Hydropsyche species (spp.) that could not be positively identified were categorized as Hydropsyche spp. or Hydropsyche morosa group. On the few occasions when Hydropsyche were not present, other caddisflies, including Brachycentrus spp. and Rhyacophila spp., were collected. The caddisfly Arctopsyche grandis and the stoneflies Claassenia sabulosa and Hesperoperla spp. were collected where available to represent additional insect taxa commonly distributed in the Clark Fork Basin but with different feeding traits.

Samples of each taxon were sorted by genus in the field and placed in acid-washed plastic containers. Samples were frozen in a small amount of ambient stream water on dry ice within 30 minutes of collection. Between 1986 and 1998, macroinvertebrate containers were kept on ice to allow the insects to evacuate their gut contents (depurate) for 6 to 8 hours. Excess water was drained and insects were frozen for transport to the laboratory. Since 1999, samples were immediately frozen on dry ice in the field to reduce the possibility of metal loss through intracellular breakdown during depuration. A comparison of immediately frozen to depurated samples indicated that although no substantial difference occurred for most metals, concentrations of copper were about 20 percent lower in the depurated samples than in the samples that were immediately frozen. The data were not adjusted for this difference.

Insect samples were processed and analyzed at the USGS NRP Ecology and Contaminants Project Laboratory in Menlo Park, Calif. Insects were thawed and rinsed with ultrapure deionized water to remove particulate matter and then sorted to their lowest possible taxonomic level. If large numbers of specimens were collected at a site, similar-sized individuals were composited into replicate subsamples. Subsamples were placed in tared scintillation vials and ovendried at $70{ }^{\circ} \mathrm{C}$. Subsamples were weighed to obtain a final dry weight and digested by reflux using concentrated nitric acid (Cain and others, 1992). After digestion, insect samples were evaporated to dryness on a hot plate. The dry residue was reconstituted in $0.6 \mathrm{~N}$ hydrochloric acid, filtered through a $0.45-\mu \mathrm{m}$ pore-size filter, and analyzed undiluted by using inductively coupled plasma-optical emission spectrometry (Hornberger and others, 1997) for arsenic, cadmium, chromium, copper, iron, lead, manganese, nickel, and zinc. The smallest concentration of a constituent that can be reliably reported for analyses of biota is termed the MRL.

\section{Results}

Concentrations of trace elements in whole-body tissue of aquatic insects collected during August 2017 are listed in table 18 . The variability in the number of composite samples among species and among sites reflects differences in insect abundance (the number of composite samples increases with the relative abundance of insects). Liquid-phase concentrations, in micrograms per milliliter, analyzed in the reconstituted samples were converted to solid-phase concentrations, in micrograms per gram, using equation 4 (used earlier in this report to calculate solid-phase concentrations of trace elements in bed sediment). All tissue samples were analyzed undiluted (the dilution ratio was 1-1). As with MRLs for trace elements in bed sediment, MRLs for trace elements in insects may differ among sites because of varied sample weights. In general, the smaller the biological-sample weight (primarily a function of insect abundance), the higher the MRL; therefore, higher MRLs do not necessarily imply a higher trace-element concentration in tissue.

\section{Quality Assurance}

The USGS protocols for field collection and processing of biota samples are designed to prevent contamination from metal sources. Nonmetallic nets, sampling equipment, and processing equipment were used in all sample collection. Equipment was acid-washed and rinsed in ultrapure deionized water before the first sample collection. Nets and equipment 
were thoroughly rinsed in stream water at each main-stem site. Clean nets were used at each tributary site. Biota samples were collected sequentially at sites along an increasing concentration gradient, which was from downstream sites to upstream sites, to minimize effects from potential site-to-site carryover contamination (Hornberger and others, 1997).

Quality control of analytical results for biota samples included laboratory-instrument calibration with standard solutions and analyses of quality-control samples designed to quantify precision and to identify the presence and magnitude of bias. Quality-control samples consisted of 12 replicates of the certified reference material (CRM) TORT-3 (lobster hepatopancreas) purchased from the National Research Council Canada. Quality-control samples were analyzed in a proportion equivalent to about 20 percent of the total number of biota samples.

Recovery efficiencies for trace-element analyses of the TORT-3 CRM are listed in table 19. Data-quality objectives have not been established for analytical recovery in biota, but percent recoveries indicate analytical performance. Mean CRM recoveries for TORT-3 ranged from 80.4 to 185 percent for all constituents. The mean recoveries were within 14 percent (based on the 95-percent confidence interval) for arsenic, cadmium, chromium, copper, iron, manganese, and zinc; 20 percent for nickel; and 185 percent for lead (likely because of the low certified concentrations in the standard). No adjustments were made to trace-element concentrations in biota samples based on recovery efficiencies.

Procedural blanks for biota consisted of undiluted aliquots of the same reagents used to digest and reconstitute tissue of aquatic insects. Analytical results of procedural blanks for biota (table 20) are reported as a liquid-phase concentration, in micrograms per milliliter. A procedural blank was prepared and analyzed concurrently with biota samples for each site. Concentrations of trace elements in all procedural blanks were less than the MRL; therefore, no adjustments to the data were necessary.

\section{Statistical Summaries of Data}

Statistical summaries of long-term water-quality, bedsediment, and biological data for the Clark Fork Basin are listed in tables 21 through 23 for the period of record at each site. The summaries include the period of record; number of samples; and maximum, minimum, mean, and median concentrations.

Statistical summaries of water-quality data (table 21) are based on results of cross-section samples collected periodically by the USGS for the long-term monitoring program in the Clark Fork Basin during the period of record for each site. The summaries do not include data for supplemental samples collected at selected sites that targeted high-flow conditions or maintenance drawdowns of Milltown Reservoir, which might disproportionately skew the long-term statistics relative to the other sites in the network. Sample results at sites that have been sampled for other projects can be accessed in the NWIS database at https://waterdata.usgs.gov/mt/nwis/qw. Statistical summaries of long-term bed-sediment (table 22) and biological data (table 23) are based on results of samples collected once each year during the indicated years. Because not all sites were sampled for bed sediment and biota every year, the data for some sites do not represent a consecutive annual record. Statistical summaries are not presented for discontinued sites.

Statistics for long-term bed-sediment data (table 22) are based on the mean trace-element concentrations determined for each year from the mean of the analyses of composite samples; therefore, the number of samples for bed sediment represents the number of years that the constituent was analyzed. The number of samples for arsenic for bed sediment is smaller than the number for other trace elements because sampling for arsenic began in September 2003. In addition, the number of samples analyzed for silver in bed sediment is smaller because analysis for this constituent was discontinued in 2004.

In contrast, statistics for long-term biological data (table 23) are based on individual analyses for each composite sample collected rather than on a single mean concentration for each year. Differences in the number of composited insect samples among species reflect differences in species abundance, both within and between sites and among years. As a result, the statistics for insects describe a wider range of variation in trace-element concentrations than would be evident if results from individual composite samples were averaged. Also, the number of samples for arsenic in insect samples is smaller than the number for other trace elements because sampling for arsenic began in September 2003. The abundance of aquatic insects at a site in a given year limits the biomass of the sample, which in turn, may result in varied MRLs. When MRLs vary among years, differences in concentration with time are difficult to determine, especially when a large percentage of the samples have concentrations less than MRLs.

The presence or absence of insect species at a given site can vary among years and may result in different taxa being analyzed in the long-term period of record. Because Hydropsyche insects were not sorted to the species level during 1986-89, statistics for sites sampled during those years are based on the results of all Hydropsyche species combined. At some sites, statistics for the Hydropsyche morosa group are based on the combined results for two or more species because these samples could not clearly be identified to the species level, but the individual insects had morosa characteristics. 


\section{References Cited}

American Public Health Association, 1998, Standard methods for the examination of water and wastewater (20th ed.): Washington, D.C., American Public Health Association, American Water Works Association, and Water Environment Federation.

Anderson, C.W., 2005, Turbidity (ver. 2.0): U.S. Geological Survey Techniques of Water-Resources Investigations, book 9, chap. A6, sec. 6.7, 64 p. [Also available at https://pubs.water.usgs.gov/twri9A6/.]

Andrews, E.D., 1987, Longitudinal dispersion of trace metals in the Clark Fork River, Montana, in Averett, R.C., and McKnight, D.M., eds., Chemical quality of water and the hydrologic cycle: Chelsea, Mich., Lewis Publishers, p. 179-191.

Axtmann, E.V., Cain, D.J., and Luoma, S.N., 1997, Effect of tributary inflows on the distribution of trace metals in fine-grained sediment and benthic insects of the Clark Fork River, Montana: Environmental Science \& Technology, v. 31, no. 3, p. 750-758. [Also available at https://doi.org/10.1021/es960417y.]

Axtmann, E.V., and Luoma, S.N., 1991, Large scale distribution of metal contamination in the fine-grained sediment of the Clark Fork River, Montana: Applied Geochemistry, v. 6, no. 1, p. 75-88. [Also available at https://doi.org/10.1016/0883-2927(91)90064-V.]

Boughton, G.K., 2018, Water-quality, bed-sediment, and biological data (October 2015 through September 2016) and statistical summaries of data for streams in the Clark Fork Basin, Montana: U.S. Geological Survey data release, accessed March 2018 at https://doi.org/10.5066/ F79C6WDM.

Boughton, G.K., 2019, Water-quality, bed-sediment, and biological data (October 2016 through September 2017) and statistical summaries of data for streams in the Clark Fork Basin, Montana: U.S. Geological Survey data release, https://doi.org/10.5066/P9YX9400.

Brenton, R.W., and Arnett, T.L., 1993, Methods of analysis by the U.S. Geological Survey National Water Quality Laboratory-Determination of dissolved organic carbon by UVpromoted persulfate oxidation and infrared spectrometry: U.S. Geological Survey Open-File Report 92-480, 12 p. [Also available at https://doi.org/10.3133/ofr92480.]

Cain, D.J., Luoma, S.N., and Axtmann, E.V., 1995, Influence of gut content in immature aquatic insects on assessments of environmental metal contamination: Canadian Journal of Fisheries and Aquatic Sciences, v. 52, no. 12, p. 2736-2746. [Also available at https://doi.org/10.1139/f95-862.]
Cain, D.J., Luoma, S.N., Carter, J.L., and Fend, S.V., 1992, Aquatic insects as bioindicators of trace element contamination in cobble-bottom rivers and streams: Canadian Journal of Fisheries and Aquatic Sciences, v. 49, no. 10, p. 21412154. [Also available at https://doi.org/10.1139/f92-237.]

Cannon, M.R., and Johnson, D.R., 2004, Estimated water use in Montana in 2000: U.S. Geological Survey Scientific Investigations Report 2004-5223, 61 p. [Also available at https://doi.org/10.3133/sir20045223.]

Davis, B.E., and the Federal Interagency Sedimentation Project, 2005, A guide to the proper selection and use of federally approved sediment and water-quality samplers: U.S. Geological Survey Open-File Report 2005-1087, 20 p. [Also available at https://doi.org/10.3133/ofr20051087.]

Dodge, K.A., and Hornberger, M.I., 2015, Water-quality, bed-sediment, and biological data (October 2013 through September 2014) and statistical summaries of data for streams in the Clark Fork Basin, Montana: U.S. Geological Survey Open-File Report 2015-1223, 125 p. [Also available at https://doi.org/10.3133/ofr20151223.]

Dodge, K.A., Hornberger, M.I., and Axtmann, E.V., 1996, Water-quality, bed-sediment, and biological data (October 1994 through September 1995) and statistical summaries of data for streams in the upper Clark Fork Basin, Montana: U.S. Geological Survey Open-File Report 96-432, 109 p. [Also available at https://doi.org/10.3133/ofr96432.]

Dodge, K.A., Hornberger, M.I., and Axtmann, E.V., 1997, Water-quality, bed-sediment, and biological data (October 1995 through September 1996) and statistical summaries of data for streams in the upper Clark Fork Basin, Montana: U.S. Geological Survey Open-File Report 97-552, 91 p. [Also available at https://doi.org/10.3133/ofr97552.]

Dodge, K.A., Hornberger, M.I., and Axtmann, E.V., 1998, Water-quality, bed-sediment, and biological data (October 1996 through September 1997) and statistical summaries of data for streams in the upper Clark Fork Basin, Montana: U.S. Geological Survey Open-File Report 98-407, 102 p. [Also available at https://doi.org/10.3133/ofr98407.]

Dodge, K.A., Hornberger, M.I., and Bouse, R.M., 1999, Water-quality, bed-sediment, and biological data (October 1997 through September 1998) and statistical summaries of data for streams in the upper Clark Fork Basin, Montana: U.S. Geological Survey Open-File Report 99-251, 102 p. [Also available at https://doi.org/10.3133/ofr99251.]

Dodge, K.A., Hornberger, M.I., and David, C.P.C., 2000, Water-quality, bed-sediment, and biological data (October 1998 through September 1999) and statistical summaries of data for streams in the upper Clark Fork Basin, Montana: U.S. Geological Survey Open-File Report 00-370, 102 p. [Also available at https://doi.org/10.3133/ofr00370.] 
Dodge, K.A., Hornberger, M.I., and David, C.P.C., 2001, Water-quality, bed-sediment, and biological data (October 1999 through September 2000) and statistical summaries of data for streams in the upper Clark Fork Basin, Montana: U.S. Geological Survey Open-File Report 01-379, 95 p. [Also available at https://doi.org/10.3133/ofr01379.]

Dodge, K.A., Hornberger, M.I., and David, C.P.C., 2002, Water-quality, bed-sediment, and biological data (October 2000 through September 2001) and statistical summaries of data for streams in the upper Clark Fork Basin, Montana: U.S. Geological Survey Open-File Report 02-358, 94 p. [Also available at https://doi.org/10.3133/ofr02358.]

Dodge, K.A., Hornberger, M.I., and Dyke, J.L., 2005, Waterquality, bed-sediment, and biological data (October 2003 through September 2004) and statistical summaries of data for streams in the upper Clark Fork Basin, Montana: U.S. Geological Survey Open-File Report 20051356, 124 p. [Also available at https://doi.org/10.3133/ ofr20051356.]

Dodge, K.A., Hornberger, M.I., and Dyke, J.L., 2006, Water-quality, bed-sediment, and biological data (October 2004 through September 2005) and statistical summaries of data for streams in the upper Clark Fork Basin, Montana: U.S. Geological Survey Open-File Report 2006-1266, 109 p. [Also available at https://pubs.usgs.gov/ of/2006/1266.]

Dodge, K.A., Hornberger, M.I., and Dyke, J.L., 2007, Waterquality, bed-sediment, and biological data (October 2005 through September 2006) and statistical summaries of long-term data for streams in the Clark Fork Basin, Montana: U.S. Geological Survey Open-File Report 20071301, 124 p. [Also available at https://doi.org/10.3133/ ofr20071301.]

Dodge, K.A., Hornberger, M.I., and Dyke, J.L., 2008, Waterquality, bed-sediment, and biological data (October 2006 through September 2007) and statistical summaries of long-term data for streams in the Clark Fork Basin, Montana: U.S. Geological Survey Open-File Report 20081318, 132 p. [Also available at https://doi.org/10.3133/ ofr20081318.]

Dodge, K.A., Hornberger, M.I., and Dyke, J.L., 2009, Water-quality, bed-sediment, and biological data (October 2007 through September 2008) and statistical summaries of long-term data for streams in the Clark Fork Basin, Montana: U.S. Geological Survey Open-File Report 2009-1178, 139 p. [Also available at https://pubs.usgs.gov/of/2009/1178.]
Dodge, K.A., Hornberger, M.I., and Dyke, J.L., 2010, Waterquality, bed-sediment, and biological data (October 2008 through September 2009) and statistical summaries of long-term data for streams in the Clark Fork Basin, Montana: U.S. Geological Survey Open-File Report 20101267, 137 p. [Also available at https://doi.org/10.3133/ ofr20101267.]

Dodge, K.A., Hornberger, M.I., and Dyke, J.L., 2012, Waterquality, bed-sediment, and biological data (October 2009 through September 2010) and statistical summaries of data for streams in the Clark Fork Basin, Montana: U.S. Geological Survey Open-File Report 2011-1314, 120 p. [Also available at https://doi.org/10.3133/ofr20111314.]

Dodge, K.A., Hornberger, M.I., and Dyke, J.L., 2013, Waterquality, bed-sediment, and biological data (October 2010 through September 2011) and statistical summaries of data for streams in the Clark Fork Basin, Montana: U.S. Geological Survey Open-File Report 2013-1017, 132 p. [Also available at https://doi.org/10.3133/ofr20131017.]

Dodge, K.A., Hornberger, M.I., and Dyke, J.L., 2014a, Waterquality, bed-sediment, and biological data (October 2011 through September 2012) and statistical summaries of data for streams in the Clark Fork Basin, Montana: U.S. Geological Survey Open-File Report 2014-1034, 121 p. [Also available at https://doi.org/10.3133/ofr20141034.]

Dodge, K.A., Hornberger, M.I., and Dyke, J.L., 2014b, Waterquality, bed-sediment, and biological data (October 2012 through September 2013) and statistical summaries of data for streams in the Clark Fork Basin, Montana: U.S. Geological Survey Open-File Report 2014-1244, 133 p. [Also available at https://doi.org/10.3133/ofr20141244.]

Dodge, K.A., Hornberger, M.I., and Lavigne, I.R., 2003, Water-quality, bed-sediment, and biological data (October 2001 through September 2002) and statistical summaries of data for streams in the upper Clark Fork Basin, Montana: U.S. Geological Survey Open-File Report 03-356, 95 p. [Also available at https://doi.org/10.3133/ofr03356.]

Dodge, K.A., Hornberger, M.I., and Lavigne, I.R., 2004, Water-quality, bed-sediment, and biological data (October 2002 through September 2003) and statistical summaries of data for streams in the upper Clark Fork Basin, Montana: U.S. Geological Survey Open-File Report 20041340, 107 p. [Also available at https://doi.org/10.3133/ ofr20041340.]

Dodge, K.A., Hornberger, M.I., and Turner, M.A., 2017, Water-quality, bed-sediment, and biological data (October 2014 through September 2015) and statistical summaries of data for streams in the Clark Fork Basin, Montana: U.S. Geological Survey Open-File Report 2016-1201, 122 p. [Also available at https://doi.org/10.3133/ ofr20161201.] 
Dodge, K.A., Hornberger, M.I., and Turner, M.A., 2018, Water-quality, bed-sediment, and biological data (October 2015 through September 2016) and statistical summaries of data for streams in the Clark Fork Basin, Montana: U.S. Geological Survey Open-File Report 2017-1136, 118 p. [Also available at https://doi.org/10.3133/ ofr20171136.]

Dodge, K.A., and Lambing, J.H., 2006, Quality-assurance plan for the analysis of suspended sediment by the U.S. Geological Survey in Montana: U.S. Geological Survey Open-File Report 2006-1242, 25 p. [Also available at https://doi.org/10.3133/ofr20061242.]

Driscoll, A., and Hatcher, J., 2010, Chain of custody: U.S. Geological Survey National Water Quality Laboratory, SOP QUAX0030.4, effective May 5, 2010, 17 p. [Also available at http://wwwnwql.cr.usgs.gov/USGS/htmls/ QUAX0030.4controlled.pdf.]

Edwards, T.K., and Glysson, G.D., 1999, Field methods for measurement of fluvial sediment: U.S. Geological Survey Techniques of Water-Resources Investigations, book 3, chap. C2, 89 p. [Also available at https://pubs.usgs.gov/ twri/twri3-c2/.]

Fishman, M.J., ed., 1993, Methods of analysis by the U.S. Geological Survey National Water Quality Laboratory-Determination of inorganic and organic constituents in water and fluvial sediments: U.S. Geological Survey Open-File Report 93-125, 217 p. [Also available at https://doi.org/10.3133/ofr93125.]

Fishman, M.J., and Friedman, L.C., 1989, Methods for determination of inorganic substances in water and fluvial sediments: U.S. Geological Survey Techniques of WaterResources Investigations, book 5, chap. A1, 545 p. [Also available at https://doi.org/10.3133/twri05A1.]

Friedman, L.C., and Erdmann, D.E., 1982, Quality assurance practices for the chemical and biological analyses of water and fluvial sediments: U.S. Geological Survey Techniques of Water-Resources Investigations, book 5, chap. A6, 181 p. [Also available at https://pubs.usgs.gov/twri/twri5a6/.]

Garbarino, J.R., Kanagy, L.K., and Cree, M.E., 2006, Determination of elements in natural-water, biota, sediment, and soil samples using collision/reaction cell inductively coupled plasma-mass spectrometry: U.S. Geological Survey Techniques and Methods, book 5, chap. B1, 88 p. [Also available at https://pubs.usgs.gov/tm/2006/tm5b1/.]
Garbarino, J.R., and Struzeski, T.M., 1998, Methods of analysis by the U.S. Geological Survey National Water Quality Laboratory-Determination of elements in whole-water digests using inductively coupled plasma-optical emission spectrometry and inductively coupled plasma-mass spectrometry: U.S. Geological Survey Open-File Report 98-165, 101 p. [Also available at https://doi.org/10.3133/ ofr98165.]

Guy, H.P., 1969, Laboratory theory and methods for sediment analysis: U.S. Geological Survey Techniques of WaterResources Investigations, book 5, chap. C1, 58 p. [Also available at https://pubs.usgs.gov/twri/twri5c1/.]

Helsel, D.R., and Cohn, T.A., 1988, Estimation of descriptive statistics for multiply censored water quality data: Water Resources Research, v. 24, no. 12, p. 1997-2004. [Also available at https://doi.org/10.1029/WR024i012p01997.]

Hoffman, G.L., Fishman, M.J., and Garbarino, J.R., 1996, Methods of analysis by the U.S. Geological Survey National Water Quality Laboratory_-In-bottle acid digestion of whole-water samples: U.S. Geological Survey Open-File Report 96-225, 28 p. [Also available at https://doi.org/10.3133/ofr96225.]

Hornberger, M.I., Lambing, J.H., Luoma, S.N., and Axtmann, E.V., 1997, Spatial and temporal trends of trace metals in surface water, bed sediment, and biota of the upper Clark Fork Basin, Montana, 1985-95: U.S. Geological Survey Open-File Report 97-669, 84 p. [Also available at https://doi.org/10.3133/ofr97669.]

Horowitz, A.J., Demas, C.R., Fitzgerald, K.K., Miller, T.L., and Rickert, D.A., 1994, U.S. Geological Survey protocol for the collection and processing of surface-water samples for the subsequent determination of inorganic constituents in filtered water: U.S. Geological Survey Open-File Report 94-539, 57 p. [Also available at https://doi.org/10.3133/ ofr94539.]

Jones, B.E., 1987, Quality control manual of the U.S. Geological Survey's National Water Quality Laboratory: U.S. Geological Survey Open-File Report 87-457, 17 p.

Lambing, J.H., 1987, Water-quality data for the Clark Fork and selected tributaries from Deer Lodge to Milltown, Montana, March 1985 through June 1986: U.S. Geological Survey Open-File Report 87-110, 48 p. [Also available at https://doi.org/10.3133/ofr87110.] 
Lambing, J.H., 1988, Water-quality data (July 1986 through September 1987) and statistical summaries (March 1985 through September 1987) for the Clark Fork and selected tributaries from Deer Lodge to Missoula, Montana: U.S. Geological Survey Open-File Report 88-308, 55 p. [Also available at https://doi.org/10.3133/ofr88308.]

Lambing, J.H., 1989, Water-quality data (October 1987 through September 1988) and statistical summaries (March 1985 through September 1988) for the Clark Fork and selected tributaries from Galen to Missoula, Montana: U.S. Geological Survey Open-File Report 89-229, 51 p. [Also available at https://doi.org/10.3133/ofr89229.]

Lambing, J.H., 1990, Water-quality data (October 1988 through September 1989) and statistical summaries (March 1985 through September 1989) for the Clark Fork and selected tributaries from Galen to Missoula, Montana: U.S. Geological Survey Open-File Report 90-168, 68 p. [Also available at https://doi.org/10.3133/ofr90168.]

Lambing, J.H., 1991, Water-quality and transport characteristics of suspended sediment and trace elements in streamflow of the upper Clark Fork Basin from Galen to Missoula, Montana, 1985-90: U.S. Geological Survey WaterResources Investigations Report 91-4139, 73 p. [Also available at https://doi.org/10.3133/wri914139.]

Lambing, J.H., comp., 2006, Quality-assurance plan for water-quality activities of the U.S. Geological Survey Montana Water Science Center: U.S. Geological Survey Open-File Report 2006-1275, 39 p. [Also available at https://pubs.usgs.gov/of/2006/1275/.]

Lambing, J.H., Hornberger, M.I., Axtmann, E.V., and Dodge, K.A., 1995, Water-quality, bed-sediment, and biological data (October 1993 through September 1994) and statistical summaries of data for streams in the upper Clark Fork Basin, Montana: U.S. Geological Survey Open-File Report 95-429, 104 p. [Also available at https://doi.org/10.3133/ ofr95429.]

Lambing, J.H., Hornberger, M.I., Axtmann, E.V., and Pope, D.A., 1994, Water-quality, bed-sediment, and biological data (October 1992 through September 1993) and statistical summaries of water-quality data (March 1985 through September 1993) for streams in the upper Clark Fork Basin, Montana: U.S. Geological Survey Open-File Report 94-375, 85 p. [Also available at https://doi.org/10.3133/ ofr94375.]

Luoma, S.N., and Bryan, G.W., 1981, A statistical assessment of the form of trace metals in oxidized estuarine sediments employing chemical extractants: Science of the Total Environment, v. 17 , no. 2, p. 165-196. [Also available at https://doi.org/10.1016/0048-9697(81)90182-0.]
Patton, C.J., and Kryskalla, J.R., 2011, Colorimetric determination of nitrate plus nitrite in water by enzymatic reduction, automated discrete analyzer methods: U.S. Geological Survey Techniques and Methods, book 5, chap. B8, 34 p. [Also available at https://pubs.usgs.gov/tm/05b08/.]

Pritt, J.W., and Raese, J.W., eds., 1995, Quality assurance/ quality control manual-National Water Quality Laboratory: U.S. Geological Survey Open-File Report 95-443, 35 p. [Also available at https://doi.org/10.3133/ofr95443.]

Rantz, S.E., and others, 1982, Measurement and computation of streamflow: U.S. Geological Survey Water-Supply Paper 2175, v. 2, $631 \mathrm{p}$.

Taylor, J.K., 1987, Quality assurance of chemical measurements: Chelsea, Mich., Lewis Publishers, 328 p.

U.S. Environmental Protection Agency, 2004, Clark Fork River Operational Unit of the Milltown Reservoir/ Clark Fork River Superfund site-Record of decisionPart 2-Decision summary: Helena, Mont., U.S. Environmental Protection Agency, 141 p. [Also available at https://www2.epa.gov/sites/production/files/documents/ Pt2DecisionSummary.pdf.]

U.S. Geological Survey, 2018, USGS water data for the Nation: U.S. Geological Survey National Water Information System database, accessed November 2018 at https://doi.org/10.5066/F7P55KJN.

U.S. Geological Survey, variously dated, National field manual for the collection of water-quality data: U.S. Geological Survey Techniques of Water-Resources Investigations, book 9, chaps. A1-A10. [Also available at https://water.usgs.gov/owq/FieldManual/.]

Wagner, R.J., Boulger, R.W., Jr., Oblinger, C.J., and Smith, B.A., 2006, Guidelines and standard procedures for continuous water-quality monitors - Station operation, record computation, and data reporting: U.S. Geological Survey Techniques and Methods, book 1, chap. D3, 51 p., 8 attachments. [Also available at https://pubs.usgs.gov/tm/2006/ tm1D3/.]

Ward, J.R., and Harr, C.A., eds., 1990, Methods for collection and processing of surface-water and bed-material samples for physical and chemical analyses: U.S. Geological Survey Open-File Report 90-140, 71 p. [Also available at https://doi.org/10.3133/ofr90140.] 

Data 
Table 4. Water-quality data for the Clark Fork Basin, Montana, October 2016 through September 2017.

[hh, hours; mm, minutes; $\mathrm{ft}^{3} / \mathrm{s}$, cubic foot per second; $\mu \mathrm{S} / \mathrm{cm}$, microsiemens per centimeter at 25 degrees Celsius; ${ }^{\circ} \mathrm{C}$, degrees Celsius; lab, laboratory; NTRU, nephelometric turbidity ratio unit; $\mathrm{mg} / \mathrm{L}$, milligram per liter; $\mathrm{CaCO}_{3}$, calcium carbonate; $\mathrm{E}$, estimated; <, less than laboratory reporting level; $\mu \mathrm{g} / \mathrm{L}$, microgram per liter; mm, millimeter; ton/d, ton per day; --, no data]

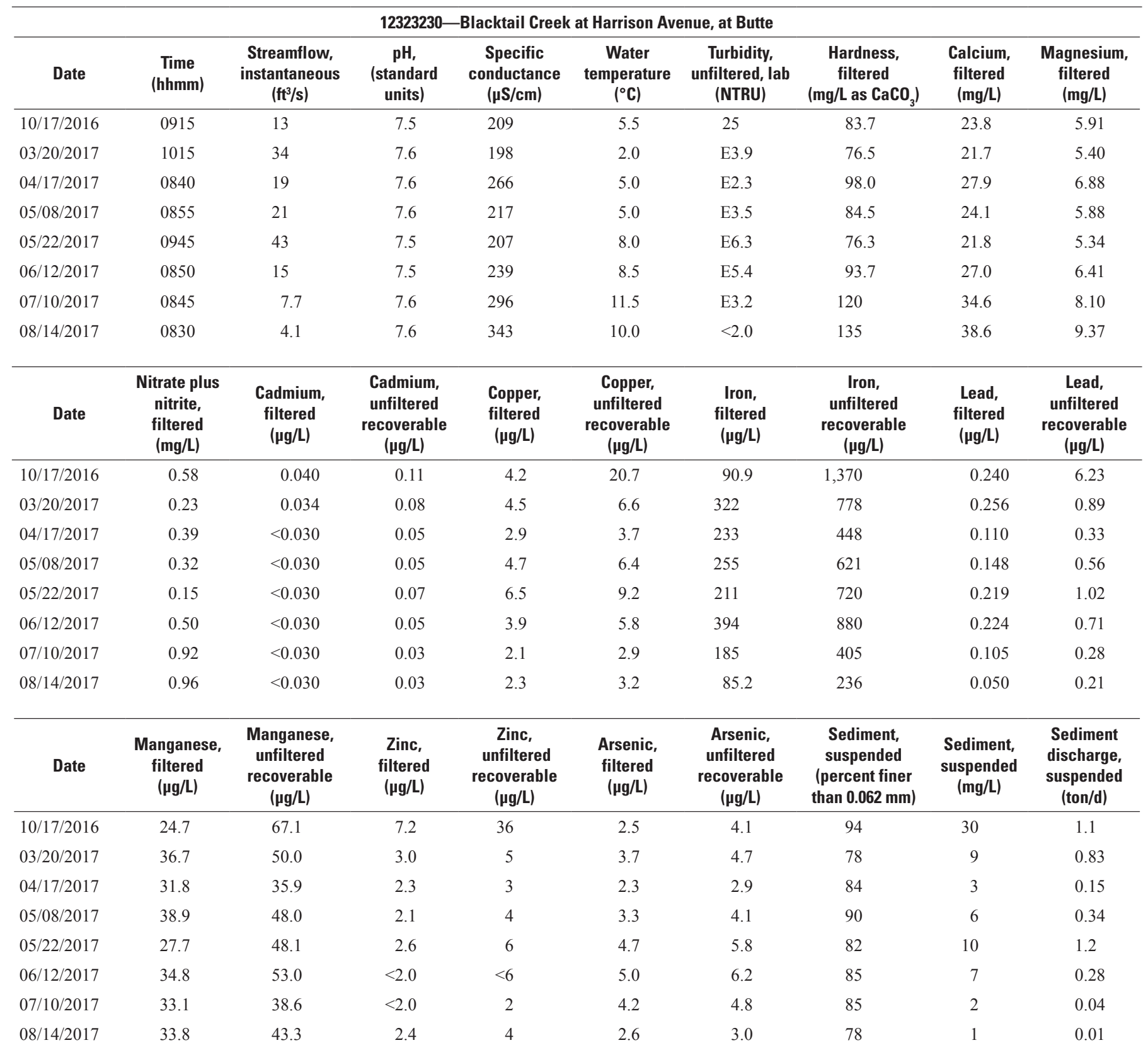


Table 4. Water-quality data for the Clark Fork Basin, Montana, October 2016 through September 2017.—Continued

[hh, hours; mm, minutes; $\mathrm{ft}^{3} / \mathrm{s}$, cubic foot per second; $\mu \mathrm{S} / \mathrm{cm}$, microsiemens per centimeter at 25 degrees Celsius; ${ }^{\circ} \mathrm{C}$, degrees Celsius; lab, laboratory; $\mathrm{NTRU}$, nephelometric turbidity ratio unit; $\mathrm{mg} / \mathrm{L}$, milligram per liter; $\mathrm{CaCO}_{3}$, calcium carbonate; E, estimated; $<$, less than laboratory reporting level; $\mu \mathrm{g} / \mathrm{L}$, microgram per liter; mm, millimeter; ton/d, ton per day; --, no data]

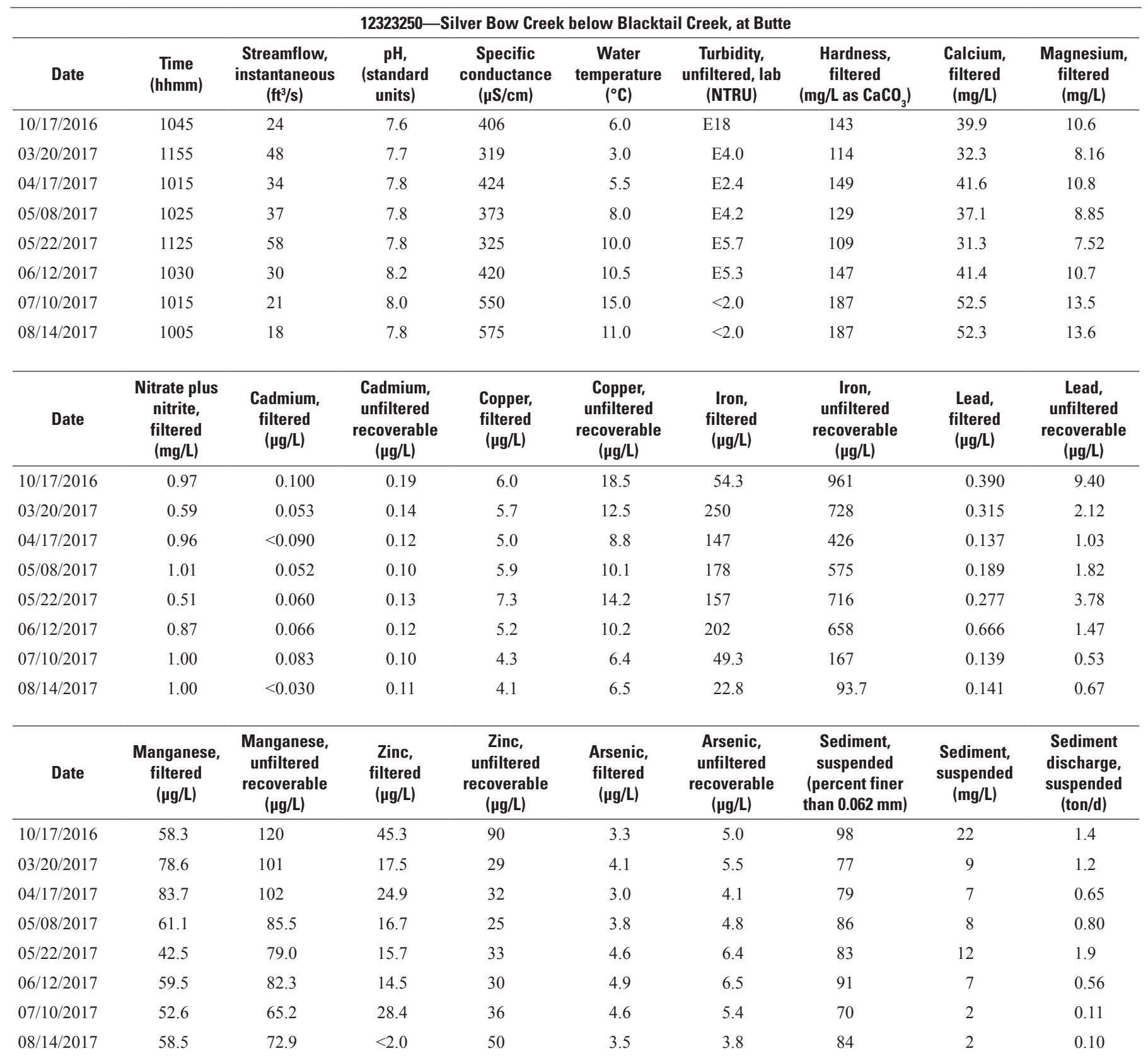


Table 4. Water-quality data for the Clark Fork Basin, Montana, October 2016 through September 2017.-Continued

[hh, hours; mm, minutes; $\mathrm{ft}^{3} / \mathrm{s}$, cubic foot per second; $\mu \mathrm{S} / \mathrm{cm}$, microsiemens per centimeter at 25 degrees Celsius; ${ }^{\circ} \mathrm{C}$, degrees Celsius; lab, laboratory; NTRU, nephelometric turbidity ratio unit; $\mathrm{mg} / \mathrm{L}$, milligram per liter; $\mathrm{CaCO}_{3}$, calcium carbonate; $\mathrm{E}$, estimated; <, less than laboratory reporting level; $\mu \mathrm{g} / \mathrm{L}$, microgram per liter; mm, millimeter; ton/d, ton per day; --, no data]

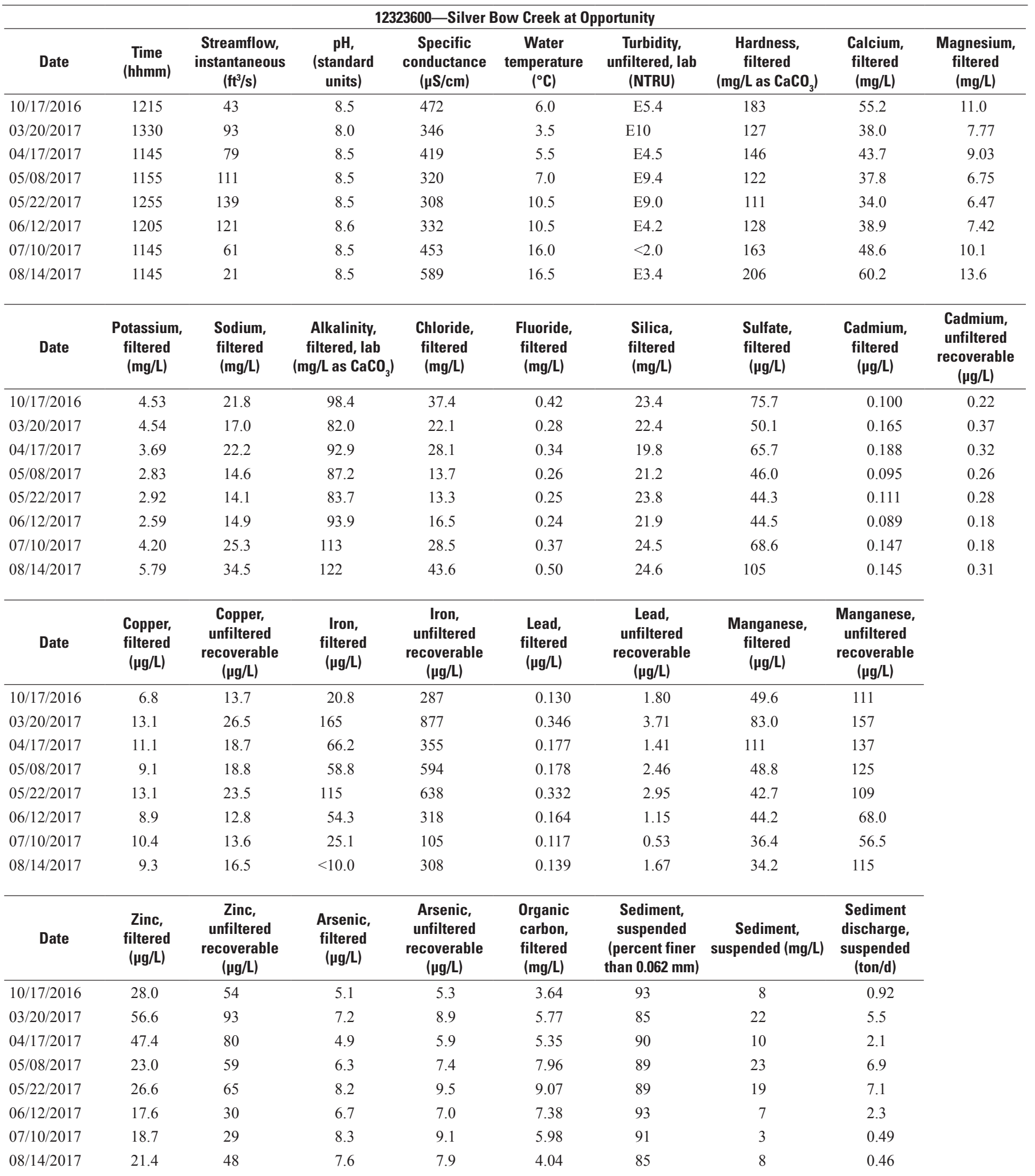


Table 4. Water-quality data for the Clark Fork Basin, Montana, October 2016 through September 2017.—Continued

[hh, hours; mm, minutes; $\mathrm{ft}^{3} / \mathrm{s}$, cubic foot per second; $\mu \mathrm{S} / \mathrm{cm}$, microsiemens per centimeter at 25 degrees Celsius; ${ }^{\circ} \mathrm{C}$, degrees Celsius; lab, laboratory; $\mathrm{NTRU}$, nephelometric turbidity ratio unit; $\mathrm{mg} / \mathrm{L}$, milligram per liter; $\mathrm{CaCO}_{3}$, calcium carbonate; E, estimated; $<$, less than laboratory reporting level; $\mu \mathrm{g} / \mathrm{L}$, microgram per liter; mm, millimeter; ton/d, ton per day; --, no data]

\begin{tabular}{|c|c|c|c|c|c|c|c|c|c|}
\hline \multicolumn{10}{|c|}{ 12323670—Mill Creek near Anaconda } \\
\hline Date & $\begin{array}{c}\text { Time } \\
\text { (hhmm) }\end{array}$ & $\begin{array}{c}\text { Streamflow, } \\
\text { instantaneous } \\
\left(\mathrm{ft}^{3} / \mathrm{s}\right)\end{array}$ & $\begin{array}{c}\mathrm{pH}, \\
\text { (standard } \\
\text { units) }\end{array}$ & $\begin{array}{c}\text { Specific } \\
\text { conductance } \\
(\mu \mathrm{S} / \mathrm{cm})\end{array}$ & $\begin{array}{c}\text { Water } \\
\text { temperature } \\
\left({ }^{\circ} \mathrm{C}\right)\end{array}$ & $\begin{array}{c}\text { Turbidity, } \\
\text { unfiltered, lab } \\
\text { (NTRU) }\end{array}$ & $\begin{array}{c}\text { Hardness, } \\
\text { filtered } \\
\text { (mg/L as } \mathrm{CaCO}_{3} \text { ) }\end{array}$ & $\begin{array}{l}\text { Calcium, } \\
\text { filtered } \\
\text { (mg/L) }\end{array}$ & $\begin{array}{l}\text { Magnesium, } \\
\text { filtered } \\
\text { (mg/L) }\end{array}$ \\
\hline 03/20/2017 & 1630 & 37 & 7.7 & 125 & 3.0 & E4.9 & 54.2 & 15.3 & 3.91 \\
\hline 04/17/2017 & 1455 & 30 & 7.8 & 144 & 7.5 & E2.5 & 60.4 & 16.6 & 4.63 \\
\hline 05/08/2017 & 1515 & 120 & 7.6 & 84 & 8.5 & E5.5 & 35.4 & 10.4 & 2.31 \\
\hline $06 / 12 / 2017$ & 1535 & 119 & 7.7 & 82 & 8.0 & E2.6 & 35.5 & 10.4 & 2.31 \\
\hline 07/10/2017 & 1445 & 55 & 7.9 & 106 & 14.0 & $<2.0$ & 48.4 & 14.0 & 3.25 \\
\hline 08/14/2017 & 1545 & 21 & 7.9 & 160 & 14.0 & $<2.0$ & 74.9 & 20.6 & 5.69 \\
\hline Date & $\begin{array}{l}\text { Potassium, } \\
\text { filtered } \\
\text { (mg/L) }\end{array}$ & $\begin{array}{l}\text { Sodium, } \\
\text { filtered } \\
\text { (mg/L) }\end{array}$ & $\begin{array}{c}\text { Alkalinity, } \\
\text { filtered, lab } \\
\text { (mg/L as } \mathrm{CaCO}_{3} \text { ) }\end{array}$ & $\begin{array}{l}\text { Chloride, } \\
\text { filtered } \\
\text { (mg/L) }\end{array}$ & $\begin{array}{l}\text { Fluoride, } \\
\text { filtered } \\
\text { (mg/L) }\end{array}$ & $\begin{array}{l}\text { Silica, } \\
\text { filtered } \\
\text { (mg/L) }\end{array}$ & $\begin{array}{c}\text { Sulfate, } \\
\text { filtered } \\
\text { ( } \mu \mathrm{g} / \mathrm{L})\end{array}$ & $\begin{array}{c}\text { Cadmium, } \\
\text { filtered } \\
(\mu \mathrm{g} / \mathrm{L})\end{array}$ & $\begin{array}{c}\text { Cadmium, } \\
\text { unfiltered } \\
\text { recoverable } \\
(\mu \mathrm{g} / \mathrm{L})\end{array}$ \\
\hline 03/20/2017 & 0.79 & 5.11 & 54.5 & 0.47 & 0.35 & 16.0 & 8.93 & 0.043 & 0.10 \\
\hline $04 / 17 / 2017$ & 0.71 & 5.72 & 62.6 & 0.41 & 0.31 & 15.5 & 8.69 & 0.038 & 0.10 \\
\hline 05/08/2017 & 0.63 & 3.70 & 36.8 & 0.29 & 0.27 & 14.7 & 4.48 & 0.038 & 0.15 \\
\hline $05 / 22 / 2017$ & 0.62 & 3.66 & 46.0 & 0.25 & 0.28 & 14.8 & 4.83 & 0.038 & 0.09 \\
\hline $06 / 12 / 2017$ & 0.45 & 2.45 & 37.5 & 0.17 & 0.29 & 10.9 & 3.54 & 0.032 & 0.07 \\
\hline $07 / 10 / 2017$ & 0.52 & 2.64 & 48.9 & 0.17 & 0.29 & 10.0 & 4.44 & 0.037 & 0.06 \\
\hline 08/14/2017 & 0.66 & 3.40 & 75.1 & 0.24 & 0.32 & 12.2 & 6.20 & $<0.030$ & 0.06 \\
\hline Date & $\begin{array}{c}\text { Copper, } \\
\text { filtered } \\
\text { ( } \mu \mathrm{g} / \mathrm{L})\end{array}$ & $\begin{array}{l}\text { Copper, } \\
\text { unfiltered } \\
\text { recoverable } \\
(\mu \mathrm{g} / \mathrm{L})\end{array}$ & $\begin{array}{l}\text { Iron, } \\
\text { filtered } \\
(\mu \mathrm{g} / \mathrm{L})\end{array}$ & $\begin{array}{c}\text { Iron, } \\
\text { unfiltered } \\
\text { recoverable } \\
(\mu \mathrm{g} / \mathrm{L})\end{array}$ & $\begin{array}{l}\text { Lead, } \\
\text { filtered } \\
(\mu \mathrm{g} / \mathrm{L})\end{array}$ & $\begin{array}{l}\text { Lead, } \\
\text { unfiltered } \\
\text { recoverable } \\
(\mu \mathrm{g} / \mathrm{L})\end{array}$ & $\begin{array}{l}\text { Manganese, } \\
\text { filtered } \\
(\mu \mathrm{g} / \mathrm{L})\end{array}$ & $\begin{array}{c}\text { Manganese, } \\
\text { unfiltered } \\
\text { recoverable } \\
(\mu \mathrm{g} / \mathrm{L})\end{array}$ & \\
\hline 07/10/2017 & 2.0 & 3.0 & 49.1 & 132 & 0.118 & 0.40 & 8.73 & 14.0 & \\
\hline 08/14/2017 & 1.5 & 2.2 & 80.0 & 147 & 0.119 & 0.36 & 10.0 & 13.7 & \\
\hline Date & $\begin{array}{c}\text { Zinc, } \\
\text { filtered } \\
(\mu \mathrm{g} / \mathrm{L})\end{array}$ & $\begin{array}{c}\text { Zinc, } \\
\text { unfiltered } \\
\text { recoverable } \\
(\mu \mathrm{g} / \mathrm{L})\end{array}$ & $\begin{array}{c}\text { Arsenic, } \\
\text { filtered } \\
\text { ( } \mu \mathrm{g} / \mathrm{L})\end{array}$ & $\begin{array}{c}\text { Arsenic, } \\
\text { unfiltered } \\
\text { recoverable } \\
(\mu \mathrm{g} / \mathrm{L})\end{array}$ & $\begin{array}{c}\text { Organic } \\
\text { carbon, } \\
\text { filtered } \\
(\mathrm{mg} / \mathrm{L})\end{array}$ & $\begin{array}{c}\text { Sediment, } \\
\text { suspended } \\
\text { (percent finer } \\
\text { than } 0.062 \mathrm{~mm} \text { ) }\end{array}$ & $\begin{array}{c}\text { Sediment, } \\
\text { suspended } \\
\text { (mg/L) }\end{array}$ & $\begin{array}{l}\text { Sediment } \\
\text { discharge, } \\
\text { suspended } \\
\text { (ton/d) }\end{array}$ & \\
\hline $10 / 17 / 2016$ & $<2.0$ & 2 & 13.2 & 13.6 & 1.59 & 75 & 1 & 0.05 & \\
\hline $03 / 20 / 2017$ & 2.5 & 4 & 18.0 & 19.9 & 4.06 & 97 & 2 & 0.2 & \\
\hline $04 / 17 / 2017$ & $<2.0$ & 3 & 18.8 & 20.5 & 2.89 & 81 & 4 & 0.32 & \\
\hline 05/08/2017 & 2.7 & 7 & 15.4 & 17.6 & 5.10 & 75 & 14 & 4.5 & \\
\hline $05 / 22 / 2017$ & $<2.0$ & 3 & 17.6 & 18.3 & 4.08 & 86 & 4 & 0.84 & \\
\hline $06 / 12 / 2017$ & $<2.0$ & 3 & 10.1 & 11.3 & 2.58 & 76 & 6 & 1.9 & \\
\hline 07/10/2017 & $<2.0$ & $<2$ & 13.3 & 14.2 & 2.11 & 60 & 3 & 0.45 & \\
\hline 08/14/2017 & $<2.0$ & $<2$ & 15.9 & 16.0 & 1.40 & 62 & 2 & 0.11 & \\
\hline
\end{tabular}


Table 4. Water-quality data for the Clark Fork Basin, Montana, October 2016 through September 2017.-Continued

[hh, hours; mm, minutes; $\mathrm{ft}^{3} / \mathrm{s}$, cubic foot per second; $\mu \mathrm{S} / \mathrm{cm}$, microsiemens per centimeter at 25 degrees Celsius; ${ }^{\circ} \mathrm{C}$, degrees Celsius; lab, laboratory; NTRU, nephelometric turbidity ratio unit; $\mathrm{mg} / \mathrm{L}$, milligram per liter; $\mathrm{CaCO}_{3}$, calcium carbonate; E, estimated; <, less than laboratory reporting level; $\mu \mathrm{g} / \mathrm{L}$, microgram per liter; mm, millimeter; ton/d, ton per day; --, no data]

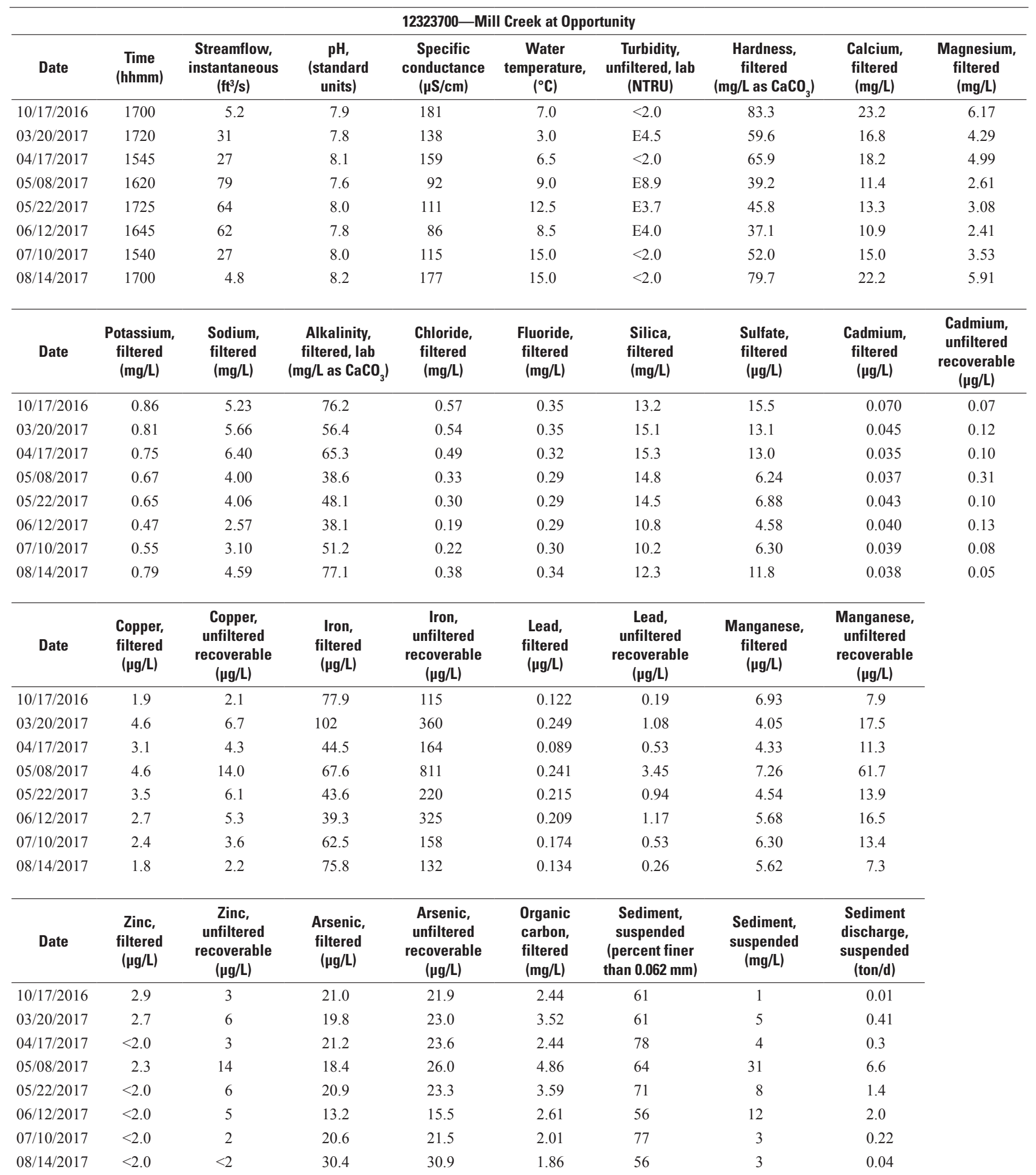


Table 4. Water-quality data for the Clark Fork Basin, Montana, October 2016 through September 2017.—Continued

[hh, hours; mm, minutes; $\mathrm{ft}^{3} / \mathrm{s}$, cubic foot per second; $\mu \mathrm{S} / \mathrm{cm}$, microsiemens per centimeter at 25 degrees Celsius; ${ }^{\circ} \mathrm{C}$, degrees Celsius; lab, laboratory; $\mathrm{NTRU}$, nephelometric turbidity ratio unit; $\mathrm{mg} / \mathrm{L}$, milligram per liter; $\mathrm{CaCO}_{3}$, calcium carbonate; E, estimated; $<$, less than laboratory reporting level; $\mu \mathrm{g} / \mathrm{L}$, microgram per liter; mm, millimeter; ton/d, ton per day; --, no data]

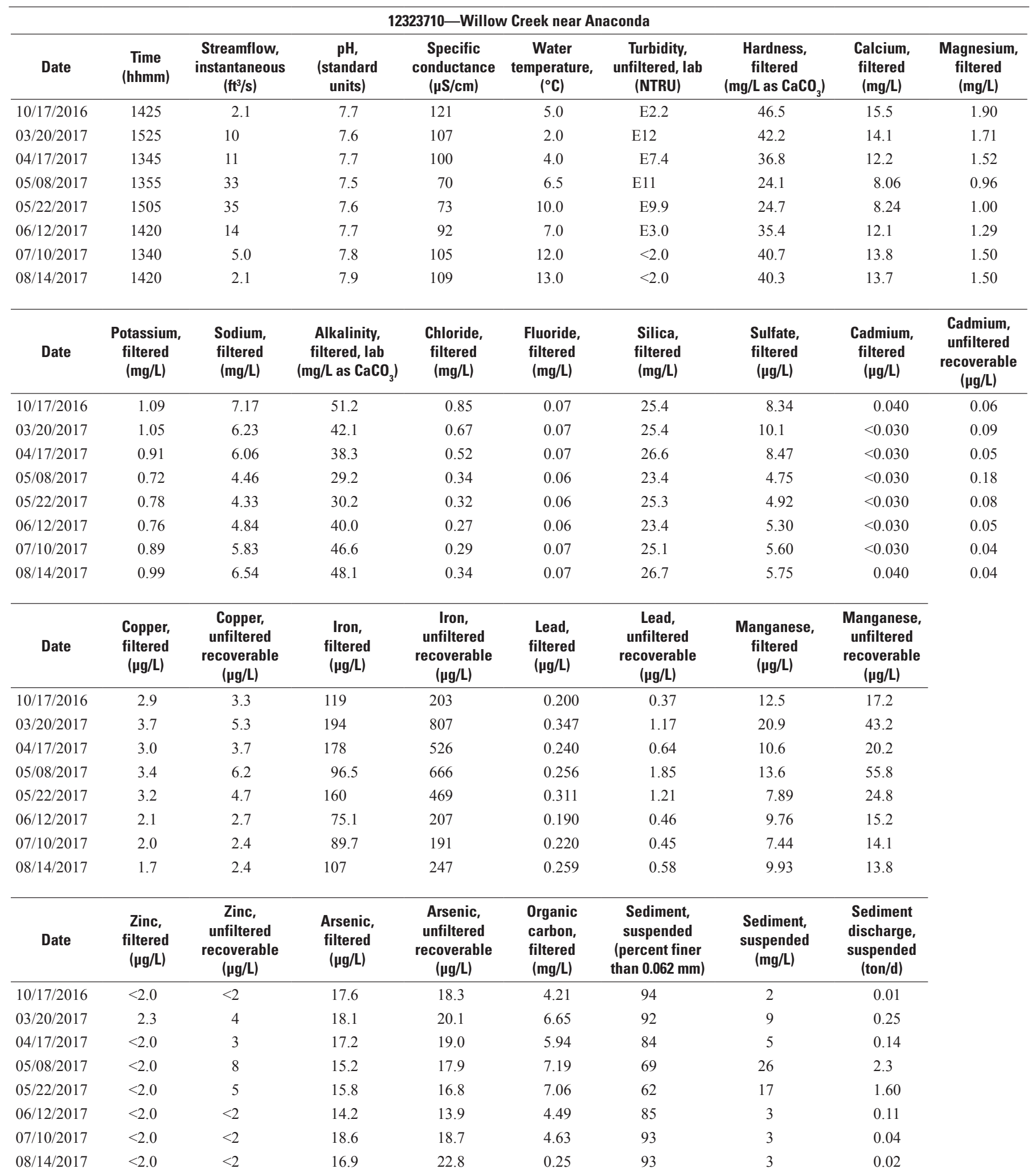


Table 4. Water-quality data for the Clark Fork Basin, Montana, October 2016 through September 2017.-Continued

[hh, hours; mm, minutes; $\mathrm{ft}^{3} / \mathrm{s}$, cubic foot per second; $\mu \mathrm{S} / \mathrm{cm}$, microsiemens per centimeter at 25 degrees Celsius; ${ }^{\circ} \mathrm{C}$, degrees Celsius; lab, laboratory; NTRU, nephelometric turbidity ratio unit; $\mathrm{mg} / \mathrm{L}$, milligram per liter; $\mathrm{CaCO}_{3}$, calcium carbonate; $\mathrm{E}$, estimated; <, less than laboratory reporting level; $\mu \mathrm{g} / \mathrm{L}$, microgram per liter; mm, millimeter; ton/d, ton per day; --, no data]

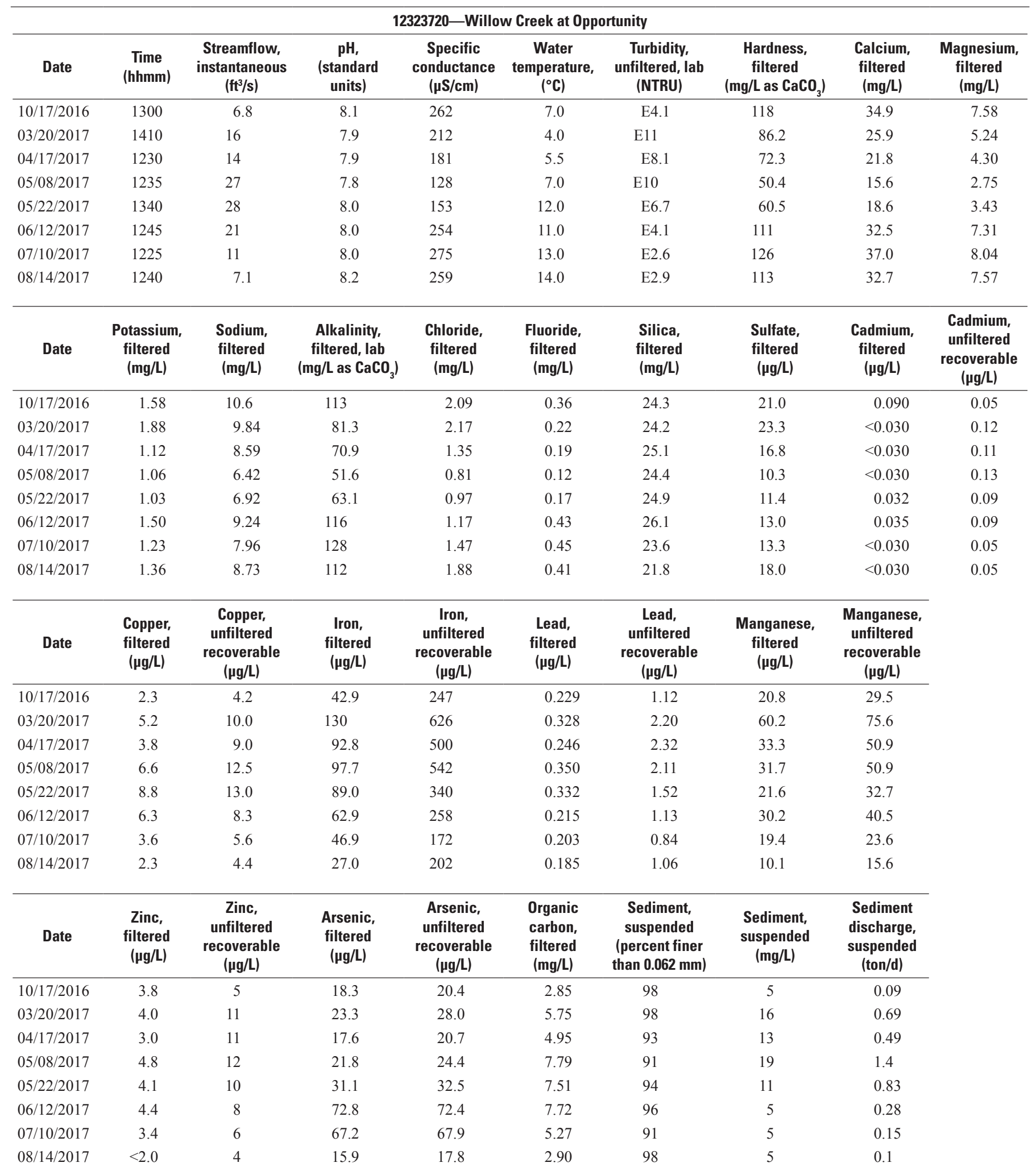


Table 4. Water-quality data for the Clark Fork Basin, Montana, October 2016 through September 2017.—Continued

[hh, hours; mm, minutes; $\mathrm{ft}^{3} / \mathrm{s}$, cubic foot per second; $\mu \mathrm{S} / \mathrm{cm}$, microsiemens per centimeter at 25 degrees Celsius; ${ }^{\circ} \mathrm{C}$, degrees Celsius; lab, laboratory; $\mathrm{NTRU}$, nephelometric turbidity ratio unit; $\mathrm{mg} / \mathrm{L}$, milligram per liter; $\mathrm{CaCO}_{3}$, calcium carbonate; E, estimated; $<$, less than laboratory reporting level; $\mu \mathrm{g} / \mathrm{L}$, microgram per liter; mm, millimeter; ton/d, ton per day; --, no data]

\begin{tabular}{|c|c|c|c|c|c|c|c|c|c|}
\hline \multicolumn{10}{|c|}{ 12323750 — Silver Bow Creek at Warm Springs } \\
\hline Date & $\begin{array}{c}\text { Time } \\
\text { (hhmm) }\end{array}$ & $\begin{array}{c}\text { Streamflow, } \\
\text { instantaneous } \\
\left(\mathrm{ft}^{3} / \mathrm{s}\right)\end{array}$ & $\begin{array}{c}\text { pH, } \\
\text { (standard } \\
\text { units) }\end{array}$ & $\begin{array}{c}\text { Specific } \\
\text { conductance } \\
\text { ( } \mathrm{SS} / \mathrm{cm})\end{array}$ & $\begin{array}{c}\text { Water } \\
\text { temperature, } \\
\left({ }^{\circ} \mathrm{C}\right)\end{array}$ & $\begin{array}{c}\text { Turbidity, } \\
\text { unfiltered, lab } \\
\text { (NTRU) }\end{array}$ & $\begin{array}{c}\text { Hardness, } \\
\text { filtered } \\
\left(\mathrm{mg} / \mathrm{L} \text { as } \mathrm{CaCO}_{3}\right)\end{array}$ & $\begin{array}{c}\text { Calcium, } \\
\text { filtered } \\
\text { (mg/L) }\end{array}$ & $\begin{array}{c}\text { Magnesium, } \\
\text { filtered } \\
(\mathrm{mg} / \mathrm{L})\end{array}$ \\
\hline $03 / 21 / 2017$ & 0930 & 161 & 8.7 & 407 & 3.5 & E6.4 & 160 & 46.3 & 10.7 \\
\hline $04 / 18 / 2017$ & 1035 & 121 & 8.3 & 431 & 6.0 & E3.8 & 165 & 48.1 & 10.9 \\
\hline $06 / 13 / 2017$ & 0945 & 385 & 7.9 & 406 & 9.5 & E7.7 & 167 & 48.4 & 11.1 \\
\hline $07 / 11 / 2017$ & 1010 & 89 & 9.2 & 317 & 14.0 & $\mathrm{E} 2.8$ & 134 & 39.3 & 8.60 \\
\hline $08 / 15 / 2017$ & 1150 & 29 & 9.4 & 418 & 15.0 & $<2.0$ & 180 & 52.2 & 12.0 \\
\hline Date & $\begin{array}{l}\text { Potassium, } \\
\text { filtered } \\
\text { (mg/L) }\end{array}$ & $\begin{array}{c}\text { Sodium, } \\
\text { filtered } \\
\text { (mg/L) }\end{array}$ & $\begin{array}{c}\text { Alkalinity, } \\
\text { filtered, lab } \\
\text { (mg/L as } \mathrm{CaCO}_{3} \text { ) }\end{array}$ & $\begin{array}{c}\text { Chloride, } \\
\text { filtered } \\
\text { (mg/L) }\end{array}$ & $\begin{array}{c}\text { Fluoride, } \\
\text { filtered } \\
\text { (mg/L) }\end{array}$ & $\begin{array}{l}\text { Silica, } \\
\text { filtered } \\
(\mathrm{mg} / \mathrm{L})\end{array}$ & $\begin{array}{c}\text { Sulfate, } \\
\text { filtered } \\
(\mu \mathrm{g} / \mathrm{L})\end{array}$ & $\begin{array}{l}\text { Cadmium, } \\
\text { filtered } \\
(\mu \mathrm{g} / \mathrm{L})\end{array}$ & $\begin{array}{c}\text { Cadmium, } \\
\text { unfiltered } \\
\text { recoverable } \\
(\mu \mathrm{g} / \mathrm{L})\end{array}$ \\
\hline $03 / 21 / 2017$ & 3.91 & 18.7 & 90.3 & 23.2 & 0.55 & 11.5 & 75.2 & 0.036 & 0.15 \\
\hline $04 / 18 / 2017$ & 3.94 & 18.4 & 97.7 & 21.5 & 0.58 & 14.1 & 79.5 & $<0.030$ & 0.12 \\
\hline 05/09/2017 & 2.97 & 14.5 & 77.0 & 15.6 & 0.47 & 15.3 & 55.6 & 0.037 & 0.14 \\
\hline $05 / 23 / 2017$ & 2.88 & 14.2 & 89.7 & 15.6 & 0.43 & 15.6 & 57.8 & 0.103 & 0.21 \\
\hline $06 / 13 / 2017$ & 3.76 & 15.5 & 98.1 & 10.2 & 0.54 & 17.1 & 88.1 & 0.065 & 0.21 \\
\hline $07 / 11 / 2017$ & 1.91 & 11.7 & 89.2 & 8.97 & 0.48 & 13.5 & 56.8 & $<0.030$ & 0.05 \\
\hline $08 / 15 / 2017$ & 2.46 & 15.2 & 102 & 11.9 & 0.63 & 17.8 & 94.8 & $<0.090$ & 0.04 \\
\hline Date & $\begin{array}{c}\text { Copper, } \\
\text { filtered } \\
\text { ( } \mu \mathrm{g} / \mathrm{L})\end{array}$ & $\begin{array}{c}\text { Copper, } \\
\text { unfiltered } \\
\text { recoverable } \\
(\mu \mathrm{g} / \mathrm{L}) \\
\end{array}$ & $\begin{array}{l}\text { Iron, } \\
\text { filtered } \\
(\mu \mathrm{g} / \mathrm{L})\end{array}$ & $\begin{array}{c}\text { Iron, } \\
\text { unfiltered } \\
\text { recoverable } \\
(\mu \mathrm{g} / \mathrm{L}) \\
\end{array}$ & $\begin{array}{l}\text { Lead, } \\
\text { filtered } \\
(\mu \mathrm{g} / \mathrm{L})\end{array}$ & $\begin{array}{c}\text { Lead, } \\
\text { unfiltered } \\
\text { recoverable } \\
(\mu \mathrm{g} / \mathrm{L})\end{array}$ & $\begin{array}{l}\text { Manganese, } \\
\text { filtered } \\
(\mu \mathrm{g} / \mathrm{L})\end{array}$ & $\begin{array}{c}\text { Manganese, } \\
\text { unfiltered } \\
\text { recoverable } \\
(\mu \mathrm{g} / \mathrm{L})\end{array}$ & \\
\hline $07 / 11 / 2017$ & 4.1 & 5.2 & 30.0 & 101 & 0.115 & 0.39 & 39.2 & 57.8 & \\
\hline 08/15/2017 & 2.4 & 2.8 & 24.7 & 85.3 & 0.088 & 0.29 & 31.0 & 64.9 & \\
\hline Date & $\begin{array}{c}\text { Zinc, } \\
\text { filtered } \\
(\mu \mathrm{g} / \mathrm{L})\end{array}$ & $\begin{array}{c}\text { Zinc, } \\
\text { unfiltered } \\
\text { recoverable } \\
(\mu \mathrm{g} / \mathrm{L})\end{array}$ & $\begin{array}{c}\text { Arsenic, } \\
\text { filtered } \\
\text { ( } \mu \mathrm{g} / \mathrm{L})\end{array}$ & $\begin{array}{c}\text { Arsenic, } \\
\text { unfiltered } \\
\text { recoverable } \\
(\mu \mathrm{g} / \mathrm{L})\end{array}$ & $\begin{array}{c}\text { Organic } \\
\text { carbon, } \\
\text { filtered } \\
(\mathrm{mg} / \mathrm{L})\end{array}$ & $\begin{array}{c}\text { Sediment, } \\
\text { suspended } \\
\text { (percent finer } \\
\text { than } 0.062 \mathrm{~mm} \text { ) }\end{array}$ & $\begin{array}{l}\text { Sediment, } \\
\text { suspended } \\
\text { (mg/L) }\end{array}$ & $\begin{array}{c}\text { Sediment } \\
\text { discharge, } \\
\text { suspended } \\
\text { (ton/d) }\end{array}$ & \\
\hline $10 / 18 / 2016$ & $<2.0$ & 4 & 17.8 & 18.8 & 4.04 & 84 & 1 & 0.1 & \\
\hline $03 / 21 / 2017$ & 4.5 & 22 & 11.7 & 14.9 & 3.84 & 95 & 10 & 4.3 & \\
\hline $04 / 18 / 2017$ & 3.8 & 15 & 10.9 & 13.9 & 4.76 & 92 & 7 & 2.3 & \\
\hline 05/09/2017 & 2.2 & 12 & 18.0 & 20.7 & 5.23 & 82 & 12 & 6.1 & \\
\hline $05 / 23 / 2017$ & 12 & 23 & 17.4 & 19.5 & 6.08 & 89 & 5 & 3.4 & \\
\hline 06/13/2017 & 7.1 & 21 & 47.5 & 48.0 & 9.29 & 83 & 20 & 21 & \\
\hline $07 / 11 / 2017$ & $<2.0$ & 3 & 26.8 & 27.6 & 4.89 & 90 & 2 & 0.48 & \\
\hline $08 / 15 / 2017$ & $<6.0$ & 2 & 25.9 & 26.9 & 4.71 & 35 & 6 & 0.46 & \\
\hline
\end{tabular}


Table 4. Water-quality data for the Clark Fork Basin, Montana, October 2016 through September 2017.-Continued

[hh, hours; mm, minutes; $\mathrm{ft}^{3} / \mathrm{s}$, cubic foot per second; $\mu \mathrm{S} / \mathrm{cm}$, microsiemens per centimeter at 25 degrees Celsius; ${ }^{\circ} \mathrm{C}$, degrees Celsius; lab, laboratory; NTRU, nephelometric turbidity ratio unit; $\mathrm{mg} / \mathrm{L}$, milligram per liter; $\mathrm{CaCO}_{3}$, calcium carbonate; $\mathrm{E}$, estimated; <, less than laboratory reporting level; $\mu \mathrm{g} / \mathrm{L}$, microgram per liter; mm, millimeter; ton/d, ton per day; --, no data]

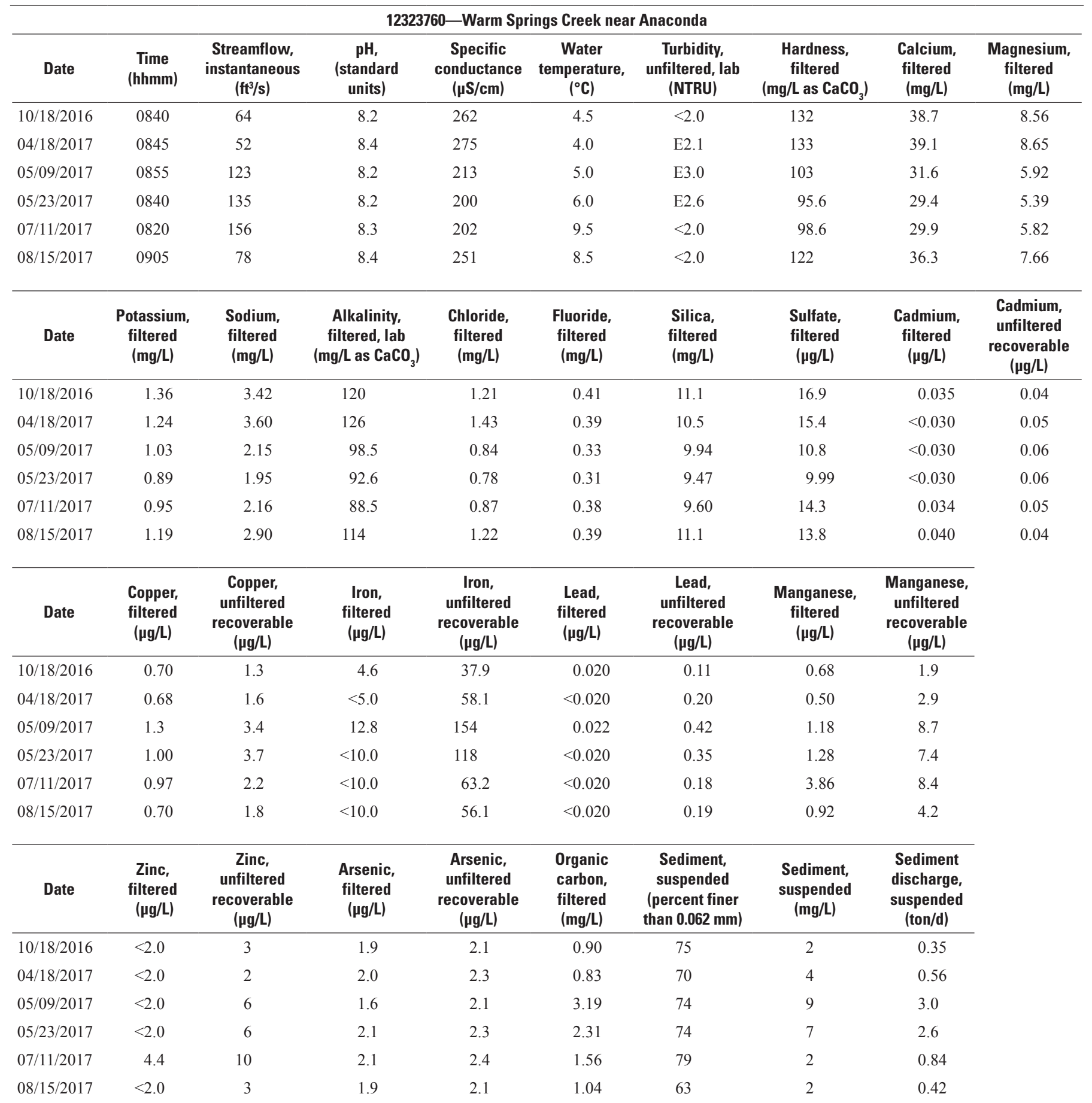


Table 4. Water-quality data for the Clark Fork Basin, Montana, October 2016 through September 2017.—Continued

[hh, hours; mm, minutes; $\mathrm{ft}^{3} / \mathrm{s}$, cubic foot per second; $\mu \mathrm{S} / \mathrm{cm}$, microsiemens per centimeter at 25 degrees Celsius; ${ }^{\circ} \mathrm{C}$, degrees Celsius; lab, laboratory; $\mathrm{NTRU}$, nephelometric turbidity ratio unit; $\mathrm{mg} / \mathrm{L}$, milligram per liter; $\mathrm{CaCO}_{3}$, calcium carbonate; E, estimated; $<$, less than laboratory reporting level; $\mu \mathrm{g} / \mathrm{L}$, microgram per liter; mm, millimeter; ton/d, ton per day; --, no data]

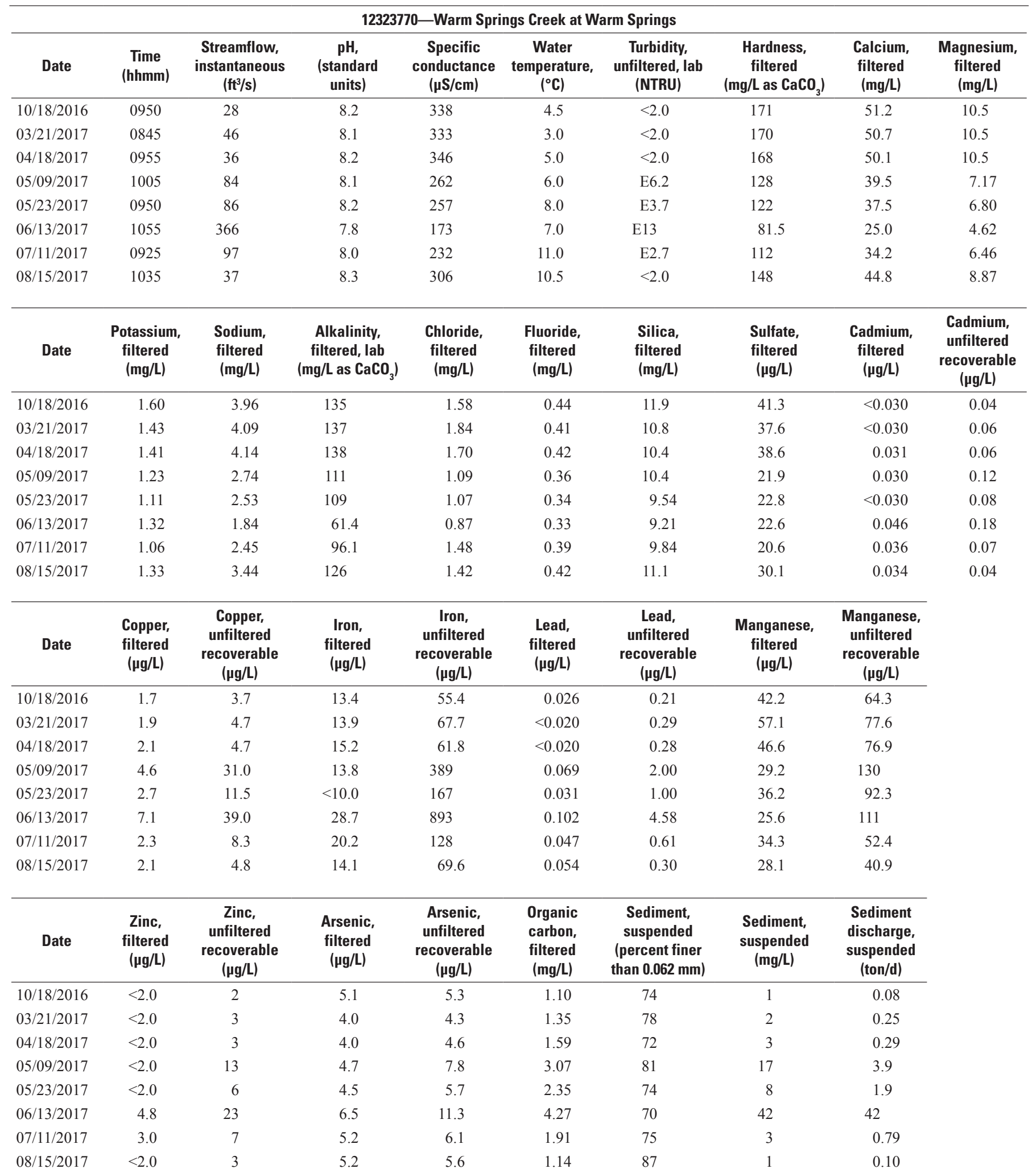


Table 4. Water-quality data for the Clark Fork Basin, Montana, October 2016 through September 2017.-Continued

[hh, hours; mm, minutes; $\mathrm{ft}^{3} / \mathrm{s}$, cubic foot per second; $\mu \mathrm{S} / \mathrm{cm}$, microsiemens per centimeter at 25 degrees Celsius; ${ }^{\circ} \mathrm{C}$, degrees Celsius; lab, laboratory; NTRU, nephelometric turbidity ratio unit; $\mathrm{mg} / \mathrm{L}$, milligram per liter; $\mathrm{CaCO}_{3}$, calcium carbonate; $\mathrm{E}$, estimated; <, less than laboratory reporting level; $\mu \mathrm{g} / \mathrm{L}$, microgram per liter; mm, millimeter; ton/d, ton per day; --, no data]

\begin{tabular}{|c|c|c|c|c|c|c|c|c|c|}
\hline \multicolumn{10}{|c|}{ 12323800 —Clark Fork near Galen } \\
\hline Date & $\underset{\text { (hhmm) }}{\text { Time }}$ & $\begin{array}{c}\text { Streamflow, } \\
\text { instantaneous } \\
\left(\mathrm{ft}^{3} / \mathrm{s}\right)\end{array}$ & $\begin{array}{c}\text { pH, } \\
\text { (standard } \\
\text { units) }\end{array}$ & $\begin{array}{c}\text { Specific } \\
\text { conductance } \\
(\mu \mathrm{S} / \mathrm{cm})\end{array}$ & $\begin{array}{c}\text { Water } \\
\text { temperature, } \\
\left({ }^{\circ} \mathrm{C}\right)\end{array}$ & $\begin{array}{c}\text { Hardness, } \\
\text { filtered } \\
\left.\text { (mg/L as } \mathrm{CaCO}_{3}\right)\end{array}$ & $\begin{array}{c}\text { Calcium, } \\
\text { filtered } \\
\text { (mg/L) }\end{array}$ & $\begin{array}{c}\text { Magnesium, } \\
\text { filtered } \\
\text { (mg/L) }\end{array}$ & \\
\hline $10 / 18 / 2016$ & 1205 & 80 & 8.4 & 434 & 6.0 & 190 & 55.0 & 12.9 & \\
\hline $03 / 21 / 2017$ & 1115 & 203 & 8.5 & 391 & 4.5 & 161 & 47.3 & 10.4 & \\
\hline $04 / 18 / 2017$ & 1210 & 155 & 8.3 & 405 & 7.0 & 168 & 49.3 & 10.9 & \\
\hline $05 / 23 / 2017$ & 1215 & 337 & 8.9 & 315 & 13.0 & 127 & 38.5 & 7.40 & \\
\hline 06/13/2017 & 1220 & 725 & 7.9 & 319 & 9.0 & 131 & 38.8 & 8.37 & \\
\hline 07/11/2017 & 1150 & 186 & 8.9 & 273 & 15.5 & 123 & 36.8 & 7.48 & \\
\hline $08 / 15 / 2017$ & 1400 & 69 & 9.0 & 363 & 16.5 & 163 & 47.7 & 10.6 & \\
\hline $10 / 18 / 2016$ & 0.030 & 0.04 & 4.2 & 5.40 & 9.60 & 57.7 & 0.04 & 0.29 & \\
\hline $03 / 21 / 2017$ & 0.037 & 0.14 & 4.1 & 12.6 & 26.8 & 376 & 0.127 & 2.56 & \\
\hline $04 / 18 / 2017$ & $<0.030$ & 0.11 & 2.9 & 11.8 & 23.5 & 315 & 0.093 & 1.77 & \\
\hline 05/09/2017 & 0.035 & 0.16 & 4.7 & 17.7 & 26.1 & 468 & 0.117 & 2.68 & \\
\hline $05 / 23 / 2017$ & 0.076 & 0.17 & 6.9 & 16.2 & 15.6 & 288 & 0.084 & 1.53 & \\
\hline $06 / 13 / 2017$ & 0.052 & 0.27 & 8.0 & 41.9 & 66.8 & 1,270 & 0.252 & 5.74 & \\
\hline $07 / 11 / 2017$ & 0.032 & 0.06 & 3.9 & 6.8 & 17.8 & 95.5 & 0.070 & 0.42 & \\
\hline 08/15/2017 & $<0.090$ & 0.05 & 3.4 & 5.5 & 13.7 & 77.3 & 0.087 & 0.43 & \\
\hline 05/09/2017 & 47.0 & 142 & $<2.0$ & 17 & 14.1 & 17.3 & 76 & 21 & 16 \\
\hline $05 / 23 / 2017$ & 49.3 & 98.7 & 3.1 & 19 & 14.6 & 16.9 & 75 & 9 & 8.2 \\
\hline $06 / 13 / 2017$ & 65.8 & 179 & 5.4 & 35 & 26.3 & 33.8 & 55 & 59 & 115 \\
\hline $07 / 11 / 2017$ & 25.6 & 45.6 & $<2.0$ & 5 & 15.5 & 16.5 & 90 & 3 & 1.5 \\
\hline $08 / 15 / 2017$ & 23.5 & 48.9 & $<6.0$ & 3 & 15.3 & 15.8 & 76 & 4 & 0.75 \\
\hline
\end{tabular}


Table 4. Water-quality data for the Clark Fork Basin, Montana, October 2016 through September 2017.—Continued

[hh, hours; mm, minutes; $\mathrm{ft}^{3} / \mathrm{s}$, cubic foot per second; $\mu \mathrm{S} / \mathrm{cm}$, microsiemens per centimeter at 25 degrees Celsius; ${ }^{\circ} \mathrm{C}$, degrees Celsius; lab, laboratory; $\mathrm{NTRU}$, nephelometric turbidity ratio unit; $\mathrm{mg} / \mathrm{L}$, milligram per liter; $\mathrm{CaCO}_{3}$, calcium carbonate; E, estimated; $<$, less than laboratory reporting level; $\mu \mathrm{g} / \mathrm{L}$, microgram per liter; mm, millimeter; ton/d, ton per day; --, no data]

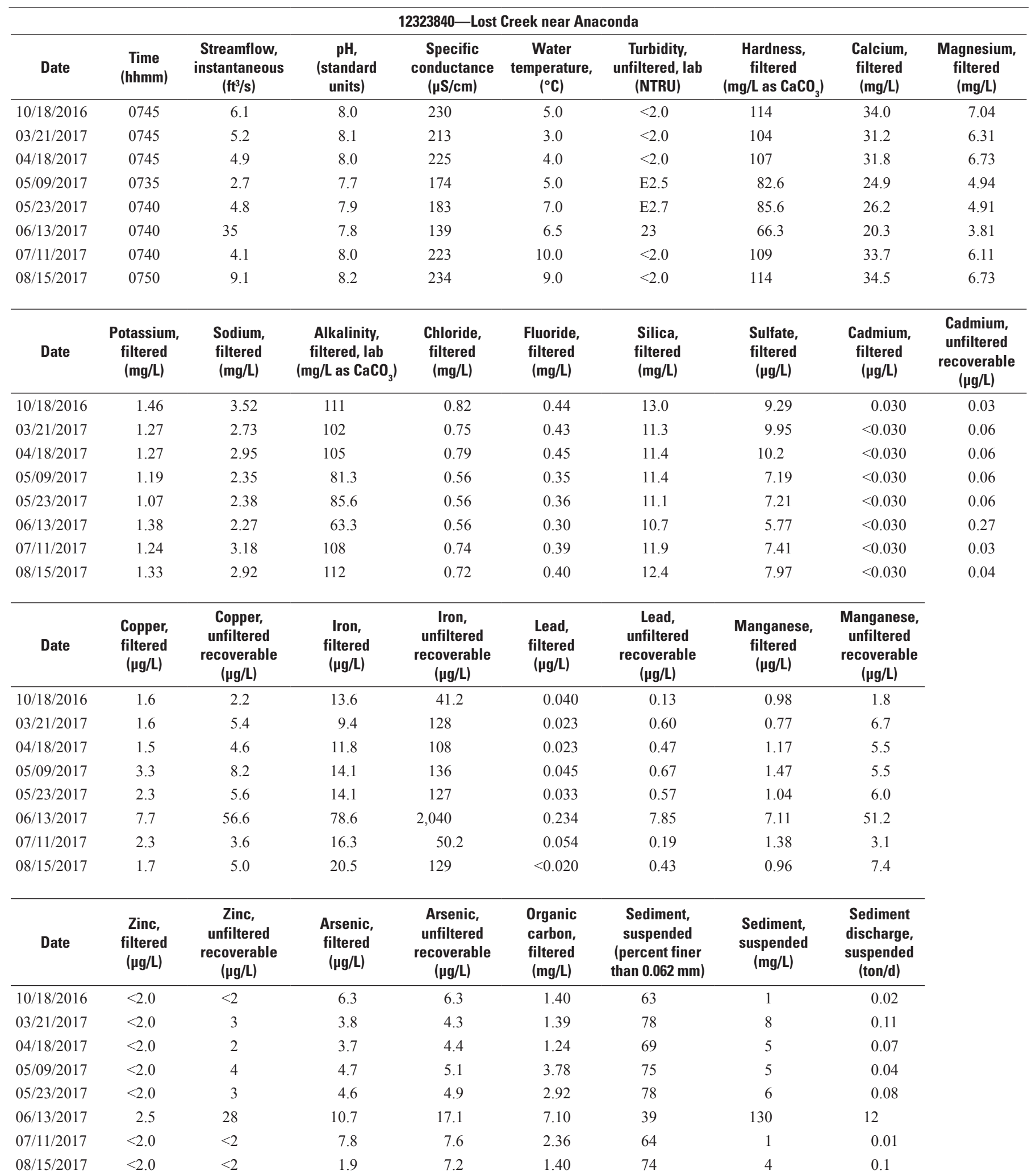


Table 4. Water-quality data for the Clark Fork Basin, Montana, October 2016 through September 2017.-Continued

[hh, hours; mm, minutes; $\mathrm{ft}^{3} / \mathrm{s}$, cubic foot per second; $\mu \mathrm{S} / \mathrm{cm}$, microsiemens per centimeter at 25 degrees Celsius; ${ }^{\circ} \mathrm{C}$, degrees Celsius; lab, laboratory; NTRU, nephelometric turbidity ratio unit; $\mathrm{mg} / \mathrm{L}$, milligram per liter; $\mathrm{CaCO}_{3}$, calcium carbonate; $\mathrm{E}$, estimated; <, less than laboratory reporting level; $\mu \mathrm{g} / \mathrm{L}$, microgram per liter; mm, millimeter; ton/d, ton per day; --, no data]

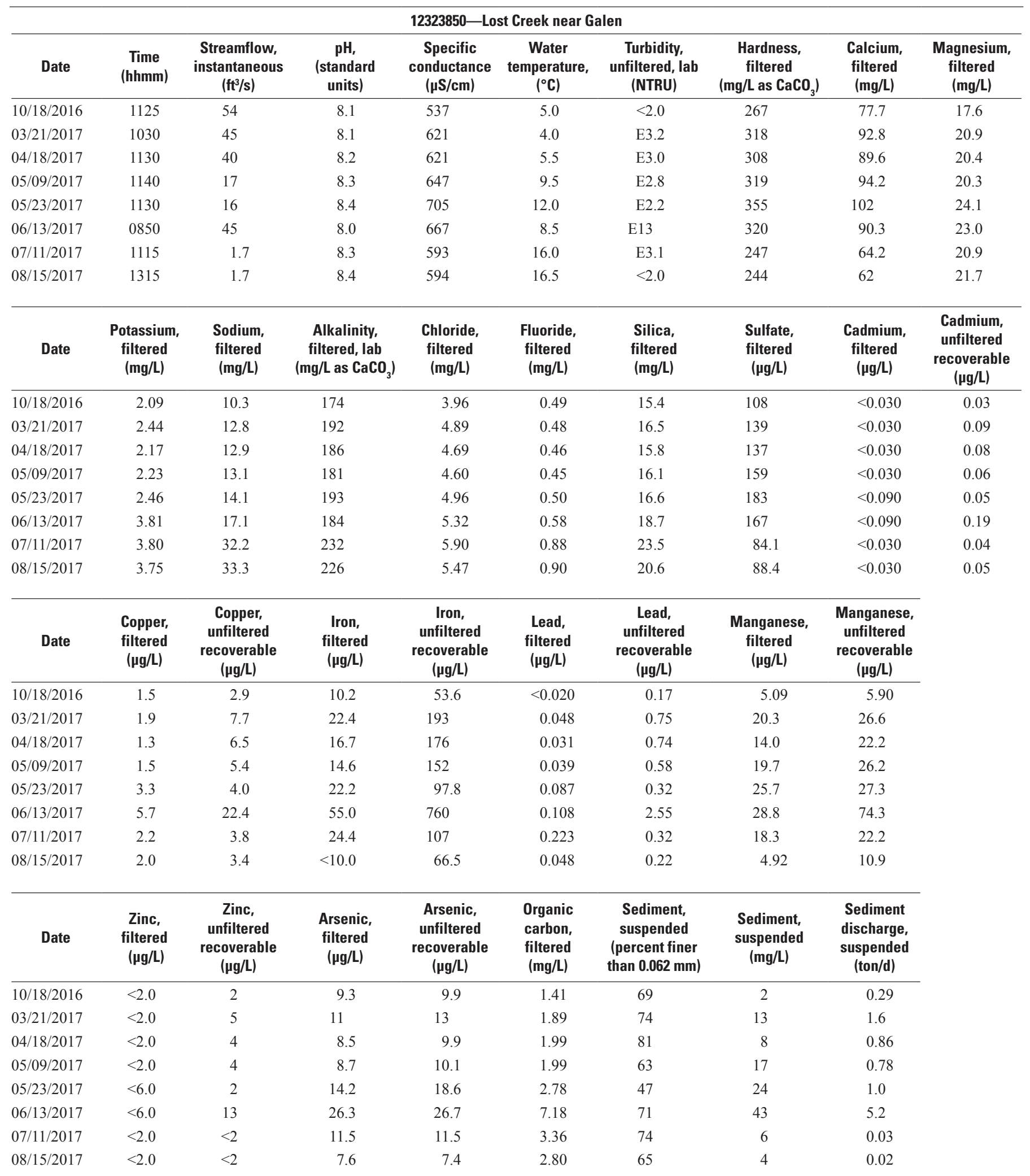


Table 4. Water-quality data for the Clark Fork Basin, Montana, October 2016 through September 2017.—Continued

[hh, hours; mm, minutes; $\mathrm{ft}^{3} / \mathrm{s}$, cubic foot per second; $\mu \mathrm{S} / \mathrm{cm}$, microsiemens per centimeter at 25 degrees Celsius; ${ }^{\circ} \mathrm{C}$, degrees Celsius; lab, laboratory; $\mathrm{NTRU}$, nephelometric turbidity ratio unit; $\mathrm{mg} / \mathrm{L}$, milligram per liter; $\mathrm{CaCO}_{3}$, calcium carbonate; E, estimated; <, less than laboratory reporting level; $\mu \mathrm{g} / \mathrm{L}$, microgram per liter; mm, millimeter; ton/d, ton per day; --, no data]

\begin{tabular}{|c|c|c|c|c|c|c|c|c|c|}
\hline \multirow[b]{2}{*}{ Date } & \multicolumn{8}{|c|}{12324200 —Clark Fork at Deer Lodge } & \\
\hline & $\begin{array}{c}\text { Time } \\
\text { (hhmm) }\end{array}$ & $\begin{array}{c}\text { Streamflow, } \\
\text { instantaneous } \\
\left(\mathrm{ft}^{3} / \mathrm{s}\right)\end{array}$ & $\begin{array}{c}\text { pH, } \\
\text { (standard } \\
\text { units) }\end{array}$ & $\begin{array}{c}\text { Specific } \\
\text { conductance } \\
(\mu \mathrm{S} / \mathrm{cm})\end{array}$ & $\begin{array}{c}\text { Water } \\
\text { temperature, } \\
\left({ }^{\circ} \mathrm{C}\right)\end{array}$ & $\begin{array}{c}\text { Hardness, } \\
\text { filtered } \\
\left(\mathrm{mg} / \mathrm{L} \text { as } \mathrm{CaCO}_{3}\right)\end{array}$ & $\begin{array}{c}\text { Calcium, } \\
\text { filtered } \\
\text { (mg/L) }\end{array}$ & $\begin{array}{c}\text { Magnesium, } \\
\text { filtered } \\
\text { (mg/L) }\end{array}$ & \\
\hline $10 / 18 / 2016$ & 1320 & 212 & 8.4 & 506 & 7.0 & 233 & 67.9 & 15.5 & \\
\hline $03 / 21 / 2017$ & 1225 & 342 & 8.2 & 435 & 5.5 & 197 & 58.1 & 12.5 & \\
\hline $04 / 18 / 2017$ & 1335 & 295 & 8.5 & 470 & 8.0 & 202 & 58.8 & 13.5 & \\
\hline $05 / 23 / 2017$ & 1355 & 369 & 8.3 & 395 & 15.5 & 165 & 48.4 & 10.7 & \\
\hline $06 / 13 / 2017$ & 1440 & 1,180 & 7.9 & 344 & 10.0 & 139 & 41.1 & 8.73 & \\
\hline 07/11/2017 & 1310 & 200 & 8.6 & 356 & 18.0 & 156 & 47.1 & 9.31 & \\
\hline $08 / 15 / 2017$ & 1545 & 83 & 8.3 & 477 & 18.5 & 204 & 60.1 & 13.1 & \\
\hline $10 / 18 / 2016$ & 0.030 & 0.11 & 5.3 & 16.3 & 7.1 & 214 & 0.040 & 1.78 & \\
\hline $03 / 21 / 2017$ & 0.062 & 0.28 & 8.1 & 56.9 & 19.1 & 922 & 0.136 & 7.37 & \\
\hline $04 / 18 / 2017$ & 0.060 & 0.17 & 6.2 & 26.3 & 16.3 & 417 & 0.081 & 3.40 & \\
\hline $05 / 09 / 2017$ & 0.060 & 0.29 & 9.2 & 60.3 & 24.1 & 883 & 0.181 & 6.88 & \\
\hline $05 / 23 / 2017$ & 0.080 & 0.32 & 11.3 & 72.4 & 18.6 & 937 & 0.201 & 7.76 & \\
\hline 06/13/2017 & 0.145 & 1.86 & 41.2 & 538 & 91.4 & 9,990 & 0.753 & 85.1 & \\
\hline $07 / 11 / 2017$ & 0.061 & 0.10 & 10.1 & 19.0 & 11.7 & 158 & 0.162 & 1.34 & \\
\hline $08 / 15 / 2017$ & 0.051 & 0.09 & 8.4 & 15.0 & 16.3 & 122 & 0.154 & 0.97 & \\
\hline $05 / 09 / 2017$ & 23.4 & 157 & 4.9 & 47 & 14.6 & 22.7 & 82 & 36 & 34 \\
\hline $05 / 23 / 2017$ & 21.1 & 127 & 7.1 & 57 & 18.7 & 27.1 & 69 & 37 & 37 \\
\hline $06 / 13 / 2017$ & 91.4 & 714 & 21.8 & 434 & 22.8 & 91.5 & 53 & 469 & 1,490 \\
\hline $07 / 11 / 2017$ & 23.9 & 39.7 & 3.5 & 12 & 17.9 & 18.7 & 87 & 6 & 3.2 \\
\hline 08/15/2017 & 19.5 & 44.0 & 4.9 & 11 & 14.8 & 15.0 & 86 & 5 & 1.1 \\
\hline
\end{tabular}


Table 4. Water-quality data for the Clark Fork Basin, Montana, October 2016 through September 2017.-Continued

[hh, hours; mm, minutes; $\mathrm{ft}^{3} / \mathrm{s}$, cubic foot per second; $\mu \mathrm{S} / \mathrm{cm}$, microsiemens per centimeter at 25 degrees Celsius; ${ }^{\circ} \mathrm{C}$, degrees Celsius; lab, laboratory; NTRU, nephelometric turbidity ratio unit; $\mathrm{mg} / \mathrm{L}$, milligram per liter; $\mathrm{CaCO}_{3}$, calcium carbonate; $\mathrm{E}$, estimated; <, less than laboratory reporting level; $\mu \mathrm{g} / \mathrm{L}$, microgram per liter; mm, millimeter; ton/d, ton per day; --, no data]

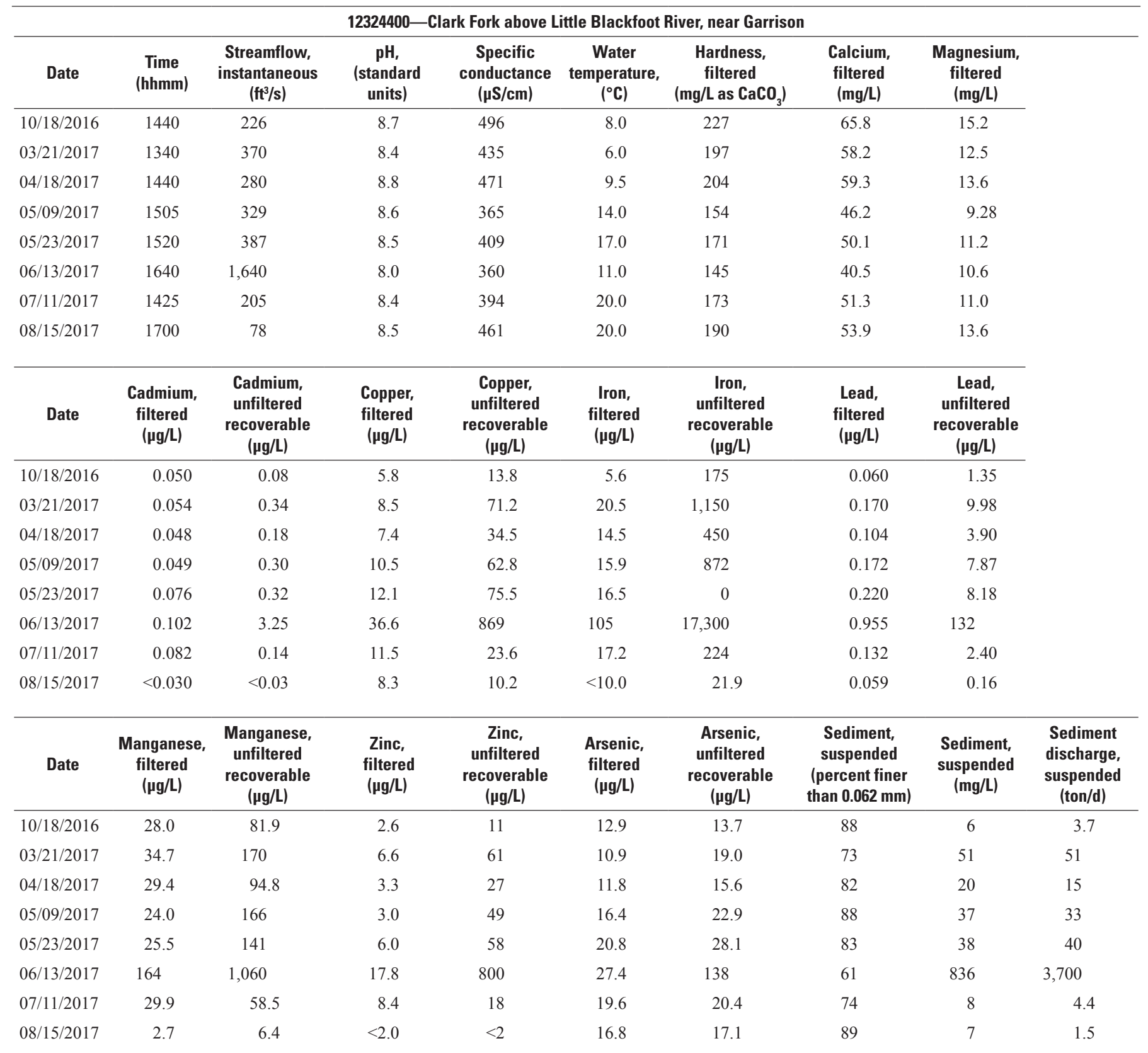


Table 4. Water-quality data for the Clark Fork Basin, Montana, October 2016 through September 2017.—Continued

[hh, hours; mm, minutes; $\mathrm{ft}^{3} / \mathrm{s}$, cubic foot per second; $\mu \mathrm{S} / \mathrm{cm}$, microsiemens per centimeter at 25 degrees Celsius; ${ }^{\circ} \mathrm{C}$, degrees Celsius; lab, laboratory; NTRU, nephelometric turbidity ratio unit; $\mathrm{mg} / \mathrm{L}$, milligram per liter; $\mathrm{CaCO}_{3}$, calcium carbonate; E, estimated; <, less than laboratory reporting level; $\mu \mathrm{g} / \mathrm{L}$, microgram per liter; mm, millimeter; ton/d, ton per day; --, no data]

\begin{tabular}{|c|c|c|c|c|c|c|c|c|c|}
\hline \multicolumn{10}{|c|}{12324680 —Clark Fork at Goldcreek } \\
\hline Date & $\begin{array}{c}\text { Time } \\
\text { (hhmm) }\end{array}$ & $\begin{array}{c}\text { Streamflow, } \\
\text { instantaneous } \\
\left(\mathrm{ft}^{3} / \mathrm{s}\right)\end{array}$ & $\begin{array}{c}\text { pH, } \\
\text { (standard } \\
\text { units) }\end{array}$ & $\begin{array}{c}\text { Specific } \\
\text { conductance } \\
(\mu \mathrm{S} / \mathrm{cm})\end{array}$ & $\begin{array}{c}\text { Water } \\
\text { temperature, } \\
\left({ }^{\circ} \mathrm{C}\right) \\
\end{array}$ & $\begin{array}{c}\text { Hardness, } \\
\text { filtered } \\
\text { (mg/L as } \mathrm{CaCO}_{3} \text { ) }\end{array}$ & $\begin{array}{c}\text { Calcium, } \\
\text { filtered } \\
\text { (mg/L) }\end{array}$ & $\begin{array}{c}\text { Magnesium, } \\
\text { filtered } \\
\text { (mg/L) }\end{array}$ & \\
\hline $10 / 18 / 2016$ & 1545 & 306 & 8.7 & 444 & 8.0 & 205 & 60.0 & 13.5 & \\
\hline $03 / 21 / 2017$ & 1450 & 617 & 8.3 & 352 & 5.5 & 155 & 45.4 & 10.0 & \\
\hline $04 / 18 / 2017$ & 1535 & 519 & 8.8 & 363 & 9.0 & 158 & 46.4 & 10.1 & \\
\hline $05 / 23 / 2017$ & 1640 & 1170 & 8.4 & 282 & 15.0 & 119 & 35.6 & 7.23 & \\
\hline $06 / 14 / 2017$ & 0815 & 3,370 & 7.9 & 305 & 9.5 & 121 & 35.1 & 8.09 & \\
\hline 07/11/2017 & 1520 & 403 & 8.5 & 375 & 20.0 & 169 & 51.0 & 10.1 & \\
\hline 08/16/2017 & 0730 & 161 & 8.1 & 442 & 13.0 & 191 & 56.2 & 12.2 & \\
\hline $10 / 18 / 2016$ & 0.040 & 0.05 & 4.6 & 8.5 & $<4.0$ & 87.2 & 0.040 & 0.68 & \\
\hline $03 / 21 / 2017$ & 0.038 & 0.24 & 6.1 & 45.8 & 49.4 & 906 & 0.216 & 8.03 & \\
\hline $04 / 18 / 2017$ & $<0.030$ & 0.12 & 4.5 & 18.6 & 11.2 & 354 & 0.054 & 2.35 & \\
\hline $05 / 09 / 2017$ & 0.032 & 0.21 & 6.3 & 36.2 & 27.8 & 833 & 0.152 & 4.89 & \\
\hline $05 / 23 / 2017$ & 0.037 & 0.20 & 6.5 & 34.0 & 47.0 & 870 & 0.220 & 4.86 & \\
\hline $06 / 14 / 2017$ & 0.102 & 1.35 & 30.9 & 295 & 106 & 8,760 & 0.734 & 44.1 & \\
\hline $07 / 11 / 2017$ & 0.051 & 0.09 & 7.6 & 14.2 & 15.8 & 184 & 0.094 & 1.13 & \\
\hline $08 / 16 / 2017$ & $<0.030$ & 0.06 & 5.0 & 17.3 & 16.4 & 123 & 0.070 & 0.71 & \\
\hline $05 / 09 / 2017$ & 14.0 & 121 & 2.1 & 35 & 9.8 & 13.8 & 87 & 36 & 76 \\
\hline $05 / 23 / 2017$ & 14.1 & 95.0 & 3.2 & 32 & 10.6 & 14.2 & 74 & 41 & 130 \\
\hline $06 / 14 / 2017$ & 46.6 & 647 & 13.4 & 317 & 19.3 & 49.9 & 60 & 394 & 3,590 \\
\hline $07 / 11 / 2017$ & 18.2 & 45.6 & $<6.0$ & 12 & 13.8 & 13.8 & 89 & 8 & 8.7 \\
\hline 08/16/2017 & 17.7 & 53.1 & 2.5 & 8 & 10.8 & 11.8 & 85 & 9 & 3.9 \\
\hline
\end{tabular}


Table 4. Water-quality data for the Clark Fork Basin, Montana, October 2016 through September 2017.-Continued

[hh, hours; mm, minutes; $\mathrm{ft}^{3} / \mathrm{s}$, cubic foot per second; $\mu \mathrm{S} / \mathrm{cm}$, microsiemens per centimeter at 25 degrees Celsius; ${ }^{\circ} \mathrm{C}$, degrees Celsius; lab, laboratory; NTRU, nephelometric turbidity ratio unit; $\mathrm{mg} / \mathrm{L}$, milligram per liter; $\mathrm{CaCO}_{3}$, calcium carbonate; $\mathrm{E}$, estimated; <, less than laboratory reporting level; $\mu \mathrm{g} / \mathrm{L}$, microgram per liter; mm, millimeter; ton/d, ton per day; --, no data]

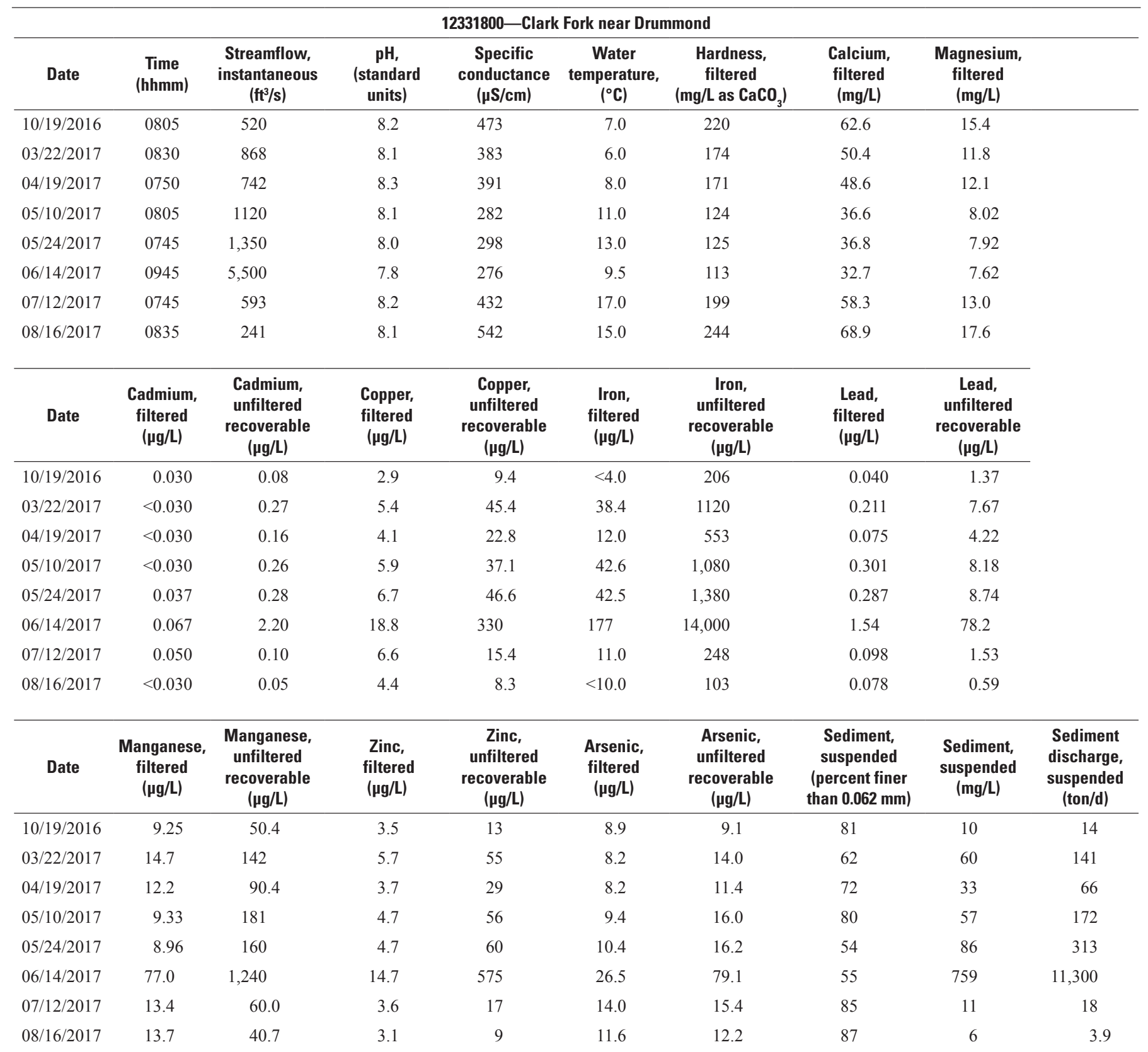


Table 4. Water-quality data for the Clark Fork Basin, Montana, October 2016 through September 2017.-Continued

[hh, hours; mm, minutes; $\mathrm{ft}^{3} / \mathrm{s}$, cubic foot per second; $\mu \mathrm{S} / \mathrm{cm}$, microsiemens per centimeter at 25 degrees Celsius; ${ }^{\circ} \mathrm{C}$, degrees Celsius; lab, laboratory; $\mathrm{NTRU}$, nephelometric turbidity ratio unit; $\mathrm{mg} / \mathrm{L}$, milligram per liter; $\mathrm{CaCO}_{3}$, calcium carbonate; E, estimated; <, less than laboratory reporting level; $\mu \mathrm{g} / \mathrm{L}$, microgram per liter; mm, millimeter; ton/d, ton per day; --, no data]

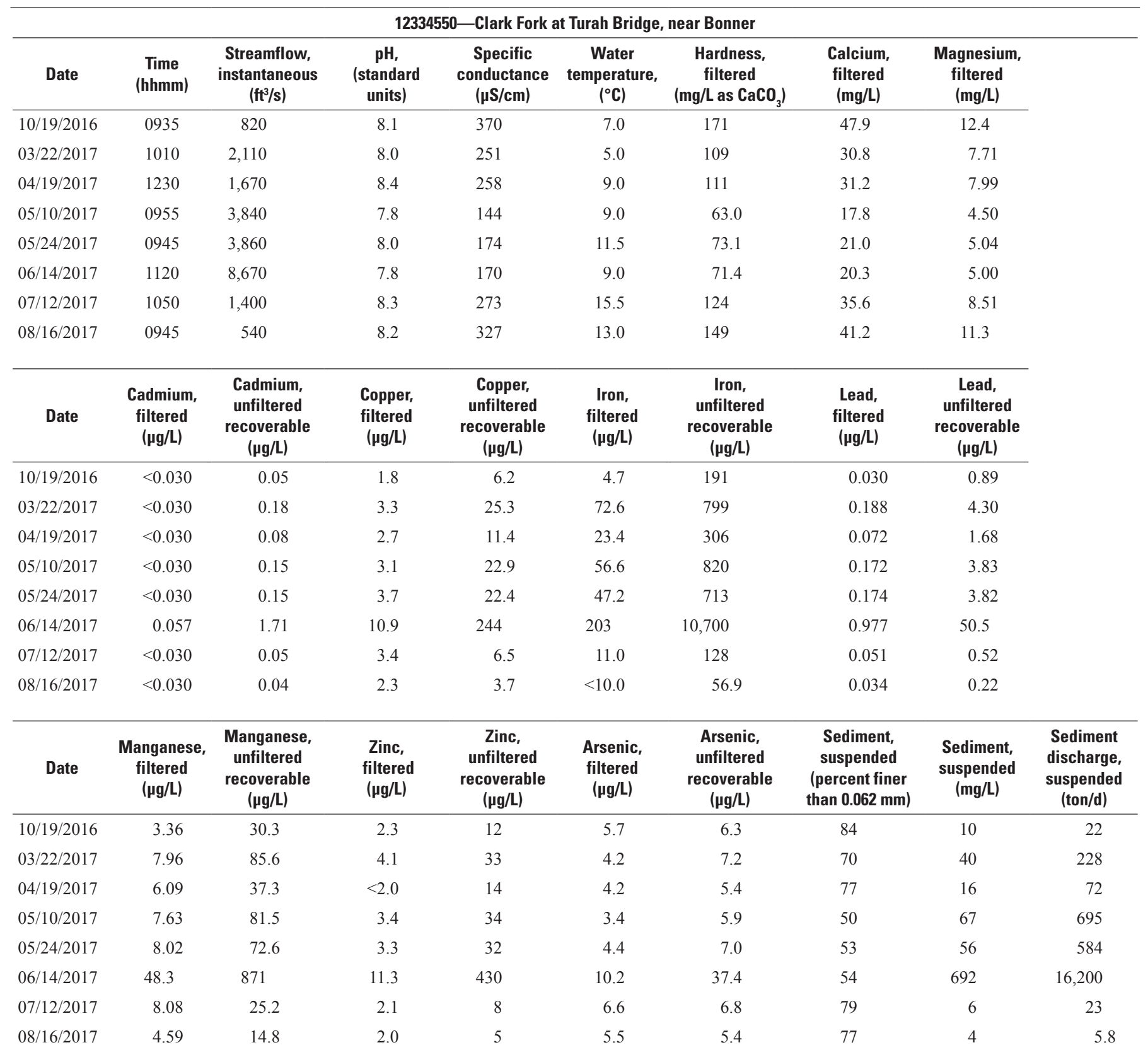


Table 4. Water-quality data for the Clark Fork Basin, Montana, October 2016 through September 2017.-Continued

[hh, hours; mm, minutes; $\mathrm{ft}^{3} / \mathrm{s}$, cubic foot per second; $\mu \mathrm{S} / \mathrm{cm}$, microsiemens per centimeter at 25 degrees Celsius; ${ }^{\circ} \mathrm{C}$, degrees Celsius; lab, laboratory; NTRU, nephelometric turbidity ratio unit; $\mathrm{mg} / \mathrm{L}$, milligram per liter; $\mathrm{CaCO}_{3}$, calcium carbonate; $\mathrm{E}$, estimated; <, less than laboratory reporting level; $\mu \mathrm{g} / \mathrm{L}$, microgram per liter; mm, millimeter; ton/d, ton per day; --, no data]

\begin{tabular}{|c|c|c|c|c|c|c|c|c|c|}
\hline \multicolumn{10}{|c|}{ 12340000—Blackfoot River near Bonner } \\
\hline Date & $\begin{array}{c}\text { Time } \\
\text { (hhmm) }\end{array}$ & $\begin{array}{c}\text { Streamflow, } \\
\text { instantaneous } \\
\left(\mathrm{ft}^{3} / \mathrm{s}\right)\end{array}$ & $\begin{array}{c}\text { pH, } \\
\text { (standard } \\
\text { units) }\end{array}$ & 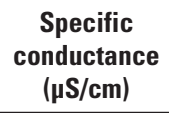 & $\begin{array}{c}\text { Water } \\
\text { temperature, } \\
\left({ }^{\circ} \mathrm{C}\right)\end{array}$ & $\begin{array}{c}\text { Hardness, } \\
\text { filtered } \\
\left(\mathrm{mg} / \mathrm{L} \text { as } \mathrm{CaCO}_{3}\right)\end{array}$ & $\begin{array}{c}\text { Calcium, } \\
\text { filtered } \\
\text { (mg/L) }\end{array}$ & $\begin{array}{c}\text { Magnesium, } \\
\text { filtered } \\
(\mathrm{mg} / \mathrm{L})\end{array}$ & \\
\hline $04 / 19 / 2017$ & 1430 & 3,240 & 8.4 & 182 & 8.0 & 87.9 & 22.7 & 7.55 & \\
\hline $05 / 10 / 2017$ & 1200 & 7,210 & 8.1 & 164 & 9.0 & 82.3 & 21.7 & 6.85 & \\
\hline $07 / 12 / 2017$ & 1255 & 1,330 & 8.5 & 239 & 17.5 & 121 & 30.9 & 10.6 & \\
\hline 08/16/2017 & 1120 & 672 & 8.5 & 264 & 14.0 & 134 & 33.0 & 12.4 & \\
\hline Date & $\begin{array}{l}\text { Cadmium, } \\
\text { filtered } \\
(\mu \mathrm{g} / \mathrm{L})\end{array}$ & $\begin{array}{c}\text { Cadmium, } \\
\text { unfiltered } \\
\text { recoverable } \\
(\mu \mathrm{g} / \mathrm{L})\end{array}$ & $\begin{array}{c}\text { Copper, } \\
\text { filtered } \\
(\mu \mathrm{g} / \mathrm{L})\end{array}$ & $\begin{array}{c}\text { Copper, } \\
\text { unfiltered } \\
\text { recoverable } \\
(\mu \mathrm{g} / \mathrm{L})\end{array}$ & $\begin{array}{c}\text { Iron, } \\
\text { filtered } \\
(\mu \mathrm{g} / \mathrm{L})\end{array}$ & $\begin{array}{c}\text { Iron, } \\
\text { unfiltered } \\
\text { recoverable } \\
(\mu \mathrm{g} / \mathrm{L})\end{array}$ & $\begin{array}{l}\text { Lead, } \\
\text { filtered } \\
(\mu \mathrm{g} / \mathrm{L})\end{array}$ & $\begin{array}{c}\text { Lead, } \\
\text { unfiltered } \\
\text { recoverable } \\
(\mu \mathrm{g} / \mathrm{L})\end{array}$ & \\
\hline $05 / 10 / 2017$ & $<0.030$ & $<0.03$ & 0.80 & 3.3 & 28.8 & 829 & 0.038 & 1.07 & \\
\hline $05 / 24 / 2017$ & $<0.030$ & $<0.03$ & 0.79 & 2.6 & 22.4 & 714 & 0.033 & 0.95 & \\
\hline $07 / 12 / 2017$ & $<0.030$ & $<0.03$ & 0.81 & 0.6 & $<10.0$ & 48.5 & 0.022 & 0.05 & \\
\hline 08/16/2017 & $<0.030$ & $<0.03$ & 0.38 & 0.5 & $<10.0$ & 31.2 & 0.021 & 0.04 & \\
\hline Date & $\begin{array}{c}\text { Manganese, } \\
\text { filtered } \\
(\mu \mathrm{g} / \mathrm{L})\end{array}$ & $\begin{array}{c}\text { Manganese, } \\
\text { unfiltered } \\
\text { recoverable } \\
(\mu \mathrm{g} / \mathrm{L})\end{array}$ & $\begin{array}{l}\text { Zinc, } \\
\text { filtered } \\
(\mu \mathrm{g} / \mathrm{L})\end{array}$ & $\begin{array}{c}\text { Zinc, } \\
\text { unfiltered } \\
\text { recoverable } \\
(\mu \mathrm{g} / \mathrm{L})\end{array}$ & $\begin{array}{c}\text { Arsenic, } \\
\text { filtered } \\
\text { ( } \mu \mathrm{g} / \mathrm{L})\end{array}$ & $\begin{array}{c}\text { Arsenic, } \\
\text { unfiltered } \\
\text { recoverable } \\
(\mu \mathrm{g} / \mathrm{L})\end{array}$ & $\begin{array}{c}\text { Sediment, } \\
\text { suspended } \\
\text { (percent finer } \\
\text { than } 0.062 \mathrm{~mm} \text { ) }\end{array}$ & $\begin{array}{l}\text { Sediment, } \\
\text { suspended } \\
\text { (mg/L) }\end{array}$ & $\begin{array}{c}\text { Sediment } \\
\text { discharge, } \\
\text { suspended } \\
\text { (ton/d) }\end{array}$ \\
\hline $10 / 19 / 2016$ & 1.51 & 5.1 & $<2.0$ & $<2$ & 1.1 & 1.1 & 80 & 3 & 5 \\
\hline
\end{tabular}


Table 4. Water-quality data for the Clark Fork Basin, Montana, October 2016 through September 2017.—Continued

[hh, hours; mm, minutes; $\mathrm{ft}^{3} / \mathrm{s}$, cubic foot per second; $\mu \mathrm{S} / \mathrm{cm}$, microsiemens per centimeter at 25 degrees Celsius; ${ }^{\circ} \mathrm{C}$, degrees Celsius; lab, laboratory; $\mathrm{NTRU}$, nephelometric turbidity ratio unit; $\mathrm{mg} / \mathrm{L}$, milligram per liter; $\mathrm{CaCO}_{3}$, calcium carbonate; E, estimated; <, less than laboratory reporting level; $\mu \mathrm{g} / \mathrm{L}$, microgram per liter; mm, millimeter; ton/d, ton per day; --, no data]

\begin{tabular}{|c|c|c|c|c|c|c|c|c|c|}
\hline \multicolumn{10}{|c|}{12340500 —Clark Fork above Missoula } \\
\hline Date & $\begin{array}{c}\text { Time } \\
\text { (hhmm) }\end{array}$ & $\begin{array}{c}\text { Streamflow, } \\
\text { instantaneous } \\
\left(\mathrm{ft}^{3} / \mathrm{s}\right)\end{array}$ & $\begin{array}{c}\text { pH } \\
\text { (standard } \\
\text { units) }\end{array}$ & $\begin{array}{c}\text { Specific } \\
\text { conductance } \\
(\mu \mathrm{S} / \mathrm{cm})\end{array}$ & $\begin{array}{c}\text { Water } \\
\text { temperature, } \\
\left({ }^{\circ} \mathrm{C}\right)\end{array}$ & $\begin{array}{c}\text { Hardness, } \\
\text { filtered } \\
\left(\mathrm{mg} / \mathrm{L} \text { as } \mathrm{CaCO}_{3}\right) \\
\end{array}$ & $\begin{array}{c}\text { Calcium, } \\
\text { filtered } \\
\text { (mg/L) }\end{array}$ & $\begin{array}{c}\text { Magnesium, } \\
\text { filtered } \\
(\mathrm{mg} / \mathrm{L})\end{array}$ & \\
\hline $10 / 19 / 2016$ & 1320 & 1,480 & 8.4 & 318 & 7.5 & 155 & 41.8 & 12.3 & \\
\hline 03/22/2017 & 1240 & 5,490 & 8.0 & 207 & 5.0 & 94.2 & 25.6 & 7.36 & \\
\hline $04 / 19 / 2017$ & 1030 & 5,070 & 8.2 & 209 & 6.5 & 95.2 & 25.6 & 7.60 & \\
\hline $05 / 24 / 2017$ & 1145 & 10,400 & 8.1 & 170 & 11.0 & 79.1 & 21.6 & 6.14 & \\
\hline $06 / 14 / 2017$ & 1345 & 15,400 & 7.9 & 173 & 10.5 & 78.6 & 21.6 & 5.96 & \\
\hline 07/12/2017 & 0930 & 2,730 & 8.2 & 255 & 15.5 & 122 & 33.4 & 9.34 & \\
\hline 08/16/2017 & 1225 & 1170 & 8.5 & 287 & 14.5 & 134 & 35.0 & 11.4 & \\
\hline $10 / 19 / 2016$ & $<0.030$ & 0.03 & 1.5 & 3.5 & 7.0 & 120 & 0.020 & 0.48 & \\
\hline $03 / 22 / 2017$ & $<0.030$ & 0.08 & 2.0 & 10.4 & 87.5 & 559 & 0.144 & 1.89 & \\
\hline 04/19/2017 & $<0.030$ & 0.05 & 1.4 & 4.4 & 24.2 & 260 & 0.041 & 0.75 & \\
\hline $05 / 10 / 2017$ & $<0.030$ & 0.08 & 1.8 & 9.2 & 38.4 & 848 & 0.093 & 1.94 & \\
\hline $05 / 24 / 2017$ & $<0.030$ & 0.08 & 2.2 & 9.8 & 31.6 & 707 & 0.088 & 1.92 & \\
\hline $06 / 14 / 2017$ & 0.033 & 1.02 & 8.0 & 155 & 150 & 5,770 & 0.724 & 27.8 & \\
\hline $07 / 12 / 2017$ & $<0.030$ & 0.03 & 2.2 & 4.3 & 10.9 & 95.2 & 0.037 & 0.33 & \\
\hline $08 / 16 / 2017$ & $<0.030$ & $<0.03$ & 1.5 & 2.1 & $<10.0$ & 70.8 & 0.036 & 0.14 & \\
\hline Date & $\begin{array}{l}\text { Manganese, } \\
\text { filtered } \\
(\mu \mathrm{g} / \mathrm{L})\end{array}$ & $\begin{array}{c}\text { Manganese, } \\
\text { unfiltered } \\
\text { recoverable } \\
(\mu \mathrm{g} / \mathrm{L})\end{array}$ & $\begin{array}{l}\text { Zinc, } \\
\text { filtered } \\
(\mu \mathrm{g} / \mathrm{L})\end{array}$ & $\begin{array}{c}\text { Zinc, } \\
\text { unfiltered } \\
\text { recoverable } \\
(\mu \mathrm{g} / \mathrm{L})\end{array}$ & $\begin{array}{c}\text { Arsenic, } \\
\text { filtered } \\
\text { ( } \mu \mathrm{g} / \mathrm{L})\end{array}$ & $\begin{array}{c}\text { Arsenic, } \\
\text { unfiltered } \\
\text { recoverable } \\
(\mu \mathrm{g} / \mathrm{L})\end{array}$ & $\begin{array}{c}\text { Sediment, } \\
\text { suspended } \\
\text { (percent finer } \\
\text { than } 0.062 \mathrm{~mm} \text { ) }\end{array}$ & $\begin{array}{c}\text { Sediment, } \\
\text { suspended } \\
\text { (mg/L) }\end{array}$ & $\begin{array}{c}\text { Sediment } \\
\text { discharge, } \\
\text { suspended } \\
\text { (ton/d) }\end{array}$ \\
\hline $05 / 10 / 2017$ & 6.80 & 62.9 & $<2.0$ & 15 & 1.9 & 3.1 & 76 & 65 & 1,910 \\
\hline $05 / 24 / 2017$ & 5.50 & 50.6 & $<2.0$ & 19 & 2.4 & 3.5 & 75 & 50 & 1,400 \\
\hline $06 / 14 / 2017$ & 44.6 & 479 & 8.6 & 259 & 7.2 & 23.7 & 65 & 350 & 14,600 \\
\hline $07 / 12 / 2017$ & 6.28 & 18.6 & $<2.0$ & 5 & 4.0 & 4.0 & 86 & 6 & 44 \\
\hline 08/16/2017 & 5.62 & 12.6 & $<2.0$ & 3 & 3.1 & 3.4 & 84 & 2 & 6.3 \\
\hline
\end{tabular}


Table 5. Seasonal daily maximum, minimum, and mean turbidity, with monthly summary statistics, at Mill Creek at Opportunity, Montana (12323700), March through September 2017.

[Turbidity values are based on near-infrared monochrome light emitted at wavelengths of 780 to 900 nanometers with a detection angle of 90 plus or minus 2.5 degrees to incident beam, reported in formazin nephelometric units (FNU). --, no data]

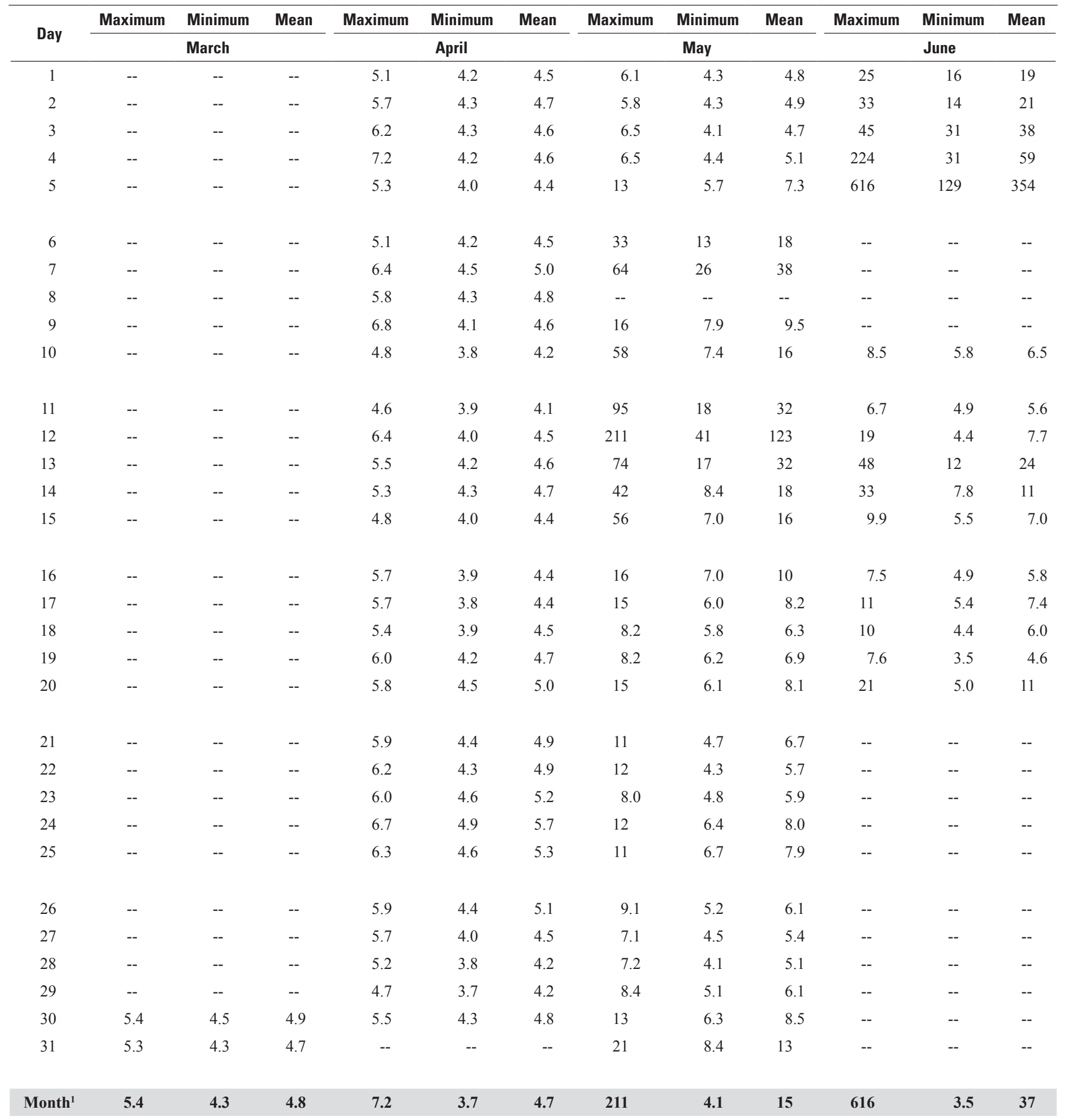


Table 5. Seasonal daily maximum, minimum, and mean turbidity, with monthly summary statistics, at Mill Creek at Opportunity, Montana (12323700), March through September 2017.-Continued

[Turbidity values are based on near-infrared monochrome light emitted at wavelengths of 780 to 900 nanometers with a detection angle of 90 plus or minus 2.5 degrees to incident beam, reported in formazin nephelometric units (FNU). --, no data]

\begin{tabular}{|c|c|c|c|c|c|c|c|c|c|}
\hline \multirow{2}{*}{ Day } & Maximum & Minimum & Mean & Maximum & Minimum & Mean & Maximum & Minimum & Mean \\
\hline & \multicolumn{3}{|c|}{ July } & \multicolumn{3}{|c|}{ August } & \multicolumn{3}{|c|}{ September } \\
\hline 1 & -- & -- & -- & 4.0 & 1.5 & 1.9 & 3.8 & 1.6 & 1.8 \\
\hline 2 & -- & -- & -- & 4.0 & 1.7 & 2.0 & 3.5 & 1.7 & 2.3 \\
\hline 3 & -- & -- & -- & 3.1 & 1.8 & 2.2 & 4.6 & 2.1 & 2.4 \\
\hline 4 & -- & -- & -- & 4.3 & 1.9 & 2.2 & 3.6 & 2.1 & 2.4 \\
\hline 5 & -- & -- & -- & 3.7 & 1.8 & 2.1 & 2.5 & 1.9 & 2.1 \\
\hline 6 & -- & -- & -- & 2.5 & 1.6 & 1.9 & 2.7 & 1.7 & 1.8 \\
\hline 7 & 5.5 & 2.5 & 3.2 & 4.9 & 1.7 & 1.9 & 3.7 & 1.5 & 1.8 \\
\hline 8 & 4.5 & 2.2 & 3.0 & 2.5 & 1.5 & 1.8 & 3.3 & 1.7 & 2.0 \\
\hline 9 & 3.9 & 2.5 & 3.1 & 3.5 & 1.6 & 1.8 & 3.5 & 1.7 & 1.9 \\
\hline 10 & 4.5 & 2.3 & 3.0 & 2.8 & 1.6 & 1.8 & 2.6 & 1.7 & 1.9 \\
\hline 11 & 4.1 & 2.3 & 2.9 & 2.3 & 1.6 & 1.8 & 2.5 & 1.8 & 2.0 \\
\hline 12 & 4.3 & 2.3 & 3.0 & 2.5 & 1.6 & 1.8 & 2.7 & 1.8 & 2.1 \\
\hline 13 & 4.2 & 2.2 & 3.0 & 4.1 & 1.7 & 2.1 & 2.4 & 1.2 & 2.1 \\
\hline 14 & 5.1 & 2.3 & 3.1 & 2.6 & 1.6 & 2.0 & 3.3 & 2.1 & 2.5 \\
\hline 15 & 4.9 & 2.4 & 3.1 & 2.2 & 1.6 & 1.7 & 4.1 & 2.2 & 3.1 \\
\hline 16 & 4.6 & 2.1 & 2.8 & 3.0 & 1.6 & 1.8 & 3.6 & 2.1 & 2.6 \\
\hline 17 & 3.6 & 2.1 & 2.7 & 4.4 & 1.6 & 1.8 & 3.3 & 1.4 & 2.3 \\
\hline 18 & 3.1 & 1.8 & 2.4 & 2.9 & 1.4 & 1.7 & 3.4 & 1.9 & 2.2 \\
\hline 19 & 3.7 & 1.8 & 2.3 & 2.7 & 1.4 & 1.6 & 4.7 & 1.9 & 2.3 \\
\hline 20 & 3.1 & 1.9 & 2.3 & 2.6 & 1.4 & 1.6 & 9.8 & 2.2 & 3.9 \\
\hline 21 & 3.0 & 1.8 & 2.3 & 3.9 & 1.4 & 1.8 & 6.7 & 1.5 & 3.0 \\
\hline 22 & 3.1 & 1.6 & 2.0 & 2.8 & 1.5 & 1.8 & 3.7 & 1.6 & 2.1 \\
\hline 23 & 2.8 & 1.6 & 2.0 & 2.7 & 1.4 & 2.1 & 3.7 & 1.6 & 2.0 \\
\hline 24 & 2.9 & 1.5 & 2.1 & 3.3 & 1.8 & 2.3 & 2.5 & 1.1 & 1.8 \\
\hline 25 & 3.4 & 1.5 & 2.1 & 4.4 & 2.0 & 2.4 & 3.7 & 1.4 & 1.7 \\
\hline 26 & 9.0 & 1.5 & 3.1 & 4.5 & 1.9 & 2.2 & 2.8 & 1.6 & 2.0 \\
\hline 27 & 8.5 & 1.4 & 2.7 & 4.7 & 2.0 & 2.5 & 3.0 & 1.8 & 2.2 \\
\hline 28 & 3.8 & 1.4 & 1.9 & 14 & 2.1 & 4.3 & 3.4 & 1.9 & 2.4 \\
\hline 29 & 3.1 & 1.3 & 1.8 & 7.7 & 2.0 & 2.6 & 3.2 & 2.0 & 2.5 \\
\hline 30 & 2.6 & 1.3 & 1.8 & 2.2 & 1.6 & 1.8 & 3.1 & 1.4 & 2.0 \\
\hline 31 & 2.9 & 1.2 & 1.7 & 2.7 & 1.5 & 1.7 & -- & -- & -- \\
\hline Month $^{1}$ & 9.0 & 1.2 & 2.5 & 14 & 1.4 & 2.0 & 9.8 & 1.1 & 2.2 \\
\hline
\end{tabular}

${ }^{1}$ For months with missing daily values, the means are calculated using available values. 
Table 6. Seasonal daily maximum, minimum, and mean turbidity, with monthly summary statistics, at Willow Creek at Opportunity, Montana (12323720), March through September 2017.

[Turbidity values are based on near-infrared monochrome light emitted at wavelengths of 780 to 900 nanometers with a detection angle of 90 plus or minus 2.5 degrees to incident beam, reported in formazin nephelometric units (FNU). --, no data]

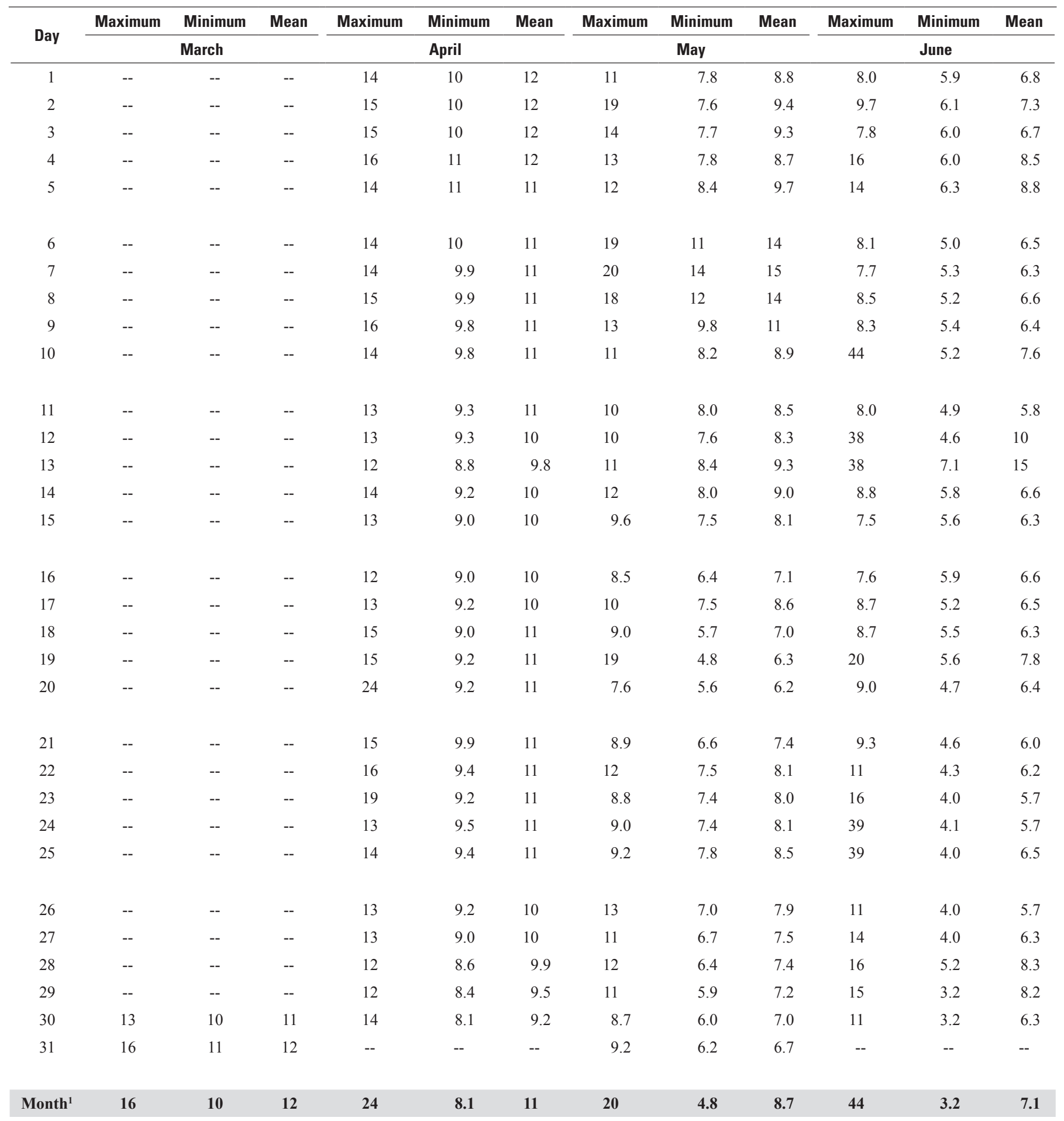


Table 6. Seasonal daily maximum, minimum, and mean turbidity, with monthly summary statistics, at Willow Creek at Opportunity, Montana (12323720), March through September 2017.-Continued

[Turbidity values are based on near-infrared monochrome light emitted at wavelengths of 780 to 900 nanometers with a detection angle of 90 plus or minus 2.5 degrees to incident beam, reported in formazin nephelometric units (FNU). --, no data]

\begin{tabular}{|c|c|c|c|c|c|c|c|c|c|}
\hline \multirow{2}{*}{ Day } & Maximum & Minimum & Mean & Maximum & Minimum & Mean & Maximum & Minimum & Mean \\
\hline & \multicolumn{3}{|c|}{ July } & \multicolumn{3}{|c|}{ August } & \multicolumn{3}{|c|}{ September } \\
\hline 1 & 13 & 3.6 & 6.1 & 5.3 & 3.2 & 4.1 & 4.9 & 2.3 & 3.1 \\
\hline 2 & -- & -- & -- & 5.3 & 3.7 & 4.4 & 4.2 & 2.5 & 3.1 \\
\hline 3 & 8.1 & 3.5 & 4.4 & 6.7 & 3.7 & 4.9 & 4.6 & 2.4 & 3.1 \\
\hline 4 & 7.8 & 3.4 & 5.1 & 6.8 & 3.5 & 4.6 & 4.1 & 2.2 & 2.9 \\
\hline 5 & 14 & 3.3 & 6.2 & 5.9 & 3.6 & 4.5 & 4.4 & 2.5 & 3.2 \\
\hline 6 & 9.6 & 3.2 & 4.3 & 5.5 & 3.7 & 4.4 & 5.8 & 2.4 & 3.5 \\
\hline 7 & 4.9 & 3.0 & 3.8 & 5.9 & 3.3 & 4.5 & 5.8 & 2.3 & 3.5 \\
\hline 8 & 6.3 & 3.1 & 3.9 & 6.2 & 3.2 & 4.4 & 7.7 & 2.4 & 3.6 \\
\hline 9 & 6.4 & 2.8 & 4.4 & 6.8 & 3.4 & 4.1 & 4.4 & 2.3 & 3.0 \\
\hline 10 & 7.0 & 2.9 & 4.0 & 4.8 & 2.9 & 3.7 & 4.6 & 2.4 & 3.1 \\
\hline 11 & 5.9 & 3.1 & 4.2 & 8.7 & 2.9 & 4.1 & 5.1 & 2.8 & 3.5 \\
\hline 12 & 6.7 & 2.7 & 4.2 & 5.7 & 3.2 & 4.2 & 5.2 & 2.4 & 3.5 \\
\hline 13 & 5.2 & 2.5 & 3.6 & 6.0 & 3.0 & 4.1 & 5.3 & 2.6 & 3.4 \\
\hline 14 & 4.2 & 2.8 & 3.3 & 6.5 & 2.9 & 3.6 & 5.2 & 3.0 & 3.7 \\
\hline 15 & 5.4 & 3.1 & 4.1 & 6.0 & 2.7 & 3.7 & 6.7 & 3.7 & 4.8 \\
\hline 16 & 6.1 & 2.8 & 4.0 & 4.4 & 2.9 & 3.5 & 5.6 & 3.2 & 4.3 \\
\hline 17 & 7.8 & 2.7 & 4.2 & 5.1 & 3.1 & 3.8 & 4.5 & 3.3 & 3.8 \\
\hline 18 & 5.8 & 2.6 & 3.9 & 5.0 & 2.9 & 3.3 & 6.0 & 3.1 & 4.0 \\
\hline 19 & 6.5 & 3.9 & 4.7 & 4.5 & 2.8 & 3.3 & 8.6 & 3.3 & 4.3 \\
\hline 20 & -- & -- & -- & 4.9 & 2.9 & 3.5 & 5.9 & 3.5 & 4.3 \\
\hline 21 & -- & -- & -- & 5.7 & 3.0 & 3.6 & 6.7 & 3.3 & 4.3 \\
\hline 22 & -- & -- & -- & 4.5 & 2.9 & 3.4 & 8.3 & 3.2 & 4.6 \\
\hline 23 & -- & -- & -- & 3.7 & 2.6 & 3.1 & 6.8 & 3.3 & 4.3 \\
\hline 24 & -- & -- & -- & 4.9 & 2.6 & 3.1 & 7.0 & 3.4 & 4.8 \\
\hline 25 & -- & -- & -- & 6.3 & 2.6 & 3.2 & 7.0 & 3.5 & 4.5 \\
\hline 26 & 9.0 & 4.4 & 6.0 & 5.9 & 3.0 & 3.5 & 6.2 & 3.5 & 4.9 \\
\hline 27 & 9.0 & 3.9 & 5.3 & 4.3 & 2.6 & 3.1 & 7.6 & 4.1 & 5.5 \\
\hline 28 & 11 & 3.5 & 5.0 & 5.4 & 2.6 & 3.3 & 6.3 & 3.5 & 5.1 \\
\hline 29 & 9.2 & 3.4 & 4.8 & 4.6 & 2.5 & 3.2 & 8.1 & 4.9 & 6.0 \\
\hline 30 & 11 & 3.5 & 5.3 & 3.8 & 2.2 & 2.9 & 8.8 & 4.7 & 6.4 \\
\hline 31 & 9.7 & 3.3 & 5.1 & 4.0 & 2.4 & 2.9 & -- & -- & -- \\
\hline Month $^{1}$ & 14 & 2.5 & 4.6 & 8.7 & 2.2 & 3.7 & 8.8 & 2.2 & 4.1 \\
\hline
\end{tabular}

${ }^{1}$ For months with missing daily values, the means are calculated using available values. 
Table 7. Seasonal daily maximum, minimum, and mean turbidity, with monthly summary statistics, at Warm Springs Creek at Warm Springs, Montana (12323770), March through September 2017.

[Turbidity values are based on near-infrared monochrome light emitted at wavelengths of 780 to 900 nanometers with a detection angle of 90 plus or minus 2.5 degrees to incident beam, reported in formazin nephelometric units (FNU). --, no data]

\begin{tabular}{|c|c|c|c|c|c|c|c|c|c|c|c|c|}
\hline \multirow{2}{*}{ Day } & Maximum & Minimum & Mean & Maximum & Minimum & Mean & Maximum & Minimum & Mean & Maximum & Minimum & Mean \\
\hline & \multicolumn{3}{|c|}{ March } & \multicolumn{3}{|c|}{ April } & \multicolumn{3}{|c|}{ May } & \multicolumn{3}{|c|}{ June } \\
\hline 1 & -- & -- & -- & 2.5 & 1.4 & 1.8 & 5.1 & 3.6 & 4.2 & 32 & 16 & 24 \\
\hline 3 & -- & -- & -- & 2.1 & 1.5 & 1.8 & 5.8 & 3.5 & 4.0 & -- & -- & -- \\
\hline 4 & -- & -- & -- & 3.0 & 1.5 & 1.8 & 5.2 & 3.4 & 4.1 & -- & -- & -- \\
\hline 6 & -- & -- & -- & 2.0 & 1.5 & 1.7 & 9.1 & 4.3 & 6.3 & -- & -- & -- \\
\hline 7 & -- & -- & -- & 2.3 & 1.6 & 1.9 & 29 & 9.1 & 21 & 21 & 11 & 13 \\
\hline 8 & -- & -- & -- & 2.2 & 1.6 & 1.8 & 18 & 7.3 & 11 & 12 & 9.6 & 11 \\
\hline 9 & -- & -- & -- & 2.4 & 1.6 & 1.9 & 11 & 6.1 & 7.5 & 12 & 8.3 & 9.3 \\
\hline 12 & -- & -- & -- & 2.9 & 1.8 & 2.2 & 23 & 10 & 15 & 23 & 5.8 & 8.6 \\
\hline 13 & -- & -- & -- & 2.9 & 1.8 & 2.2 & 26 & 13 & 18 & 47 & 13 & 25 \\
\hline 14 & -- & -- & -- & 3.1 & 1.9 & 2.3 & 13 & 6.6 & 8.6 & 44 & 15 & 24 \\
\hline 15 & -- & -- & -- & 2.5 & 1.8 & 2.1 & 7.3 & 5.0 & 6.0 & 16 & 10 & 12 \\
\hline 16 & -- & -- & -- & 2.9 & 1.6 & 2.1 & 6.1 & 4.3 & 5.0 & 12 & 8.4 & 9.4 \\
\hline 17 & -- & -- & -- & 2.9 & 2.0 & 2.3 & 6.0 & 4.2 & 5.2 & 8.8 & 7.3 & 7.7 \\
\hline 18 & -- & -- & -- & 3.5 & 2.0 & 2.4 & 5.7 & 3.5 & 4.2 & 7.8 & 6.1 & 6.7 \\
\hline 19 & -- & -- & -- & 3.8 & 1.9 & 2.4 & 5.0 & 3.2 & 4.0 & 8.1 & 6.0 & 6.5 \\
\hline 25 & -- & -- & -- & 5.1 & 3.1 & 3.8 & 20 & 9.0 & 14 & 5.7 & 3.9 & 4.6 \\
\hline 26 & -- & -- & -- & 5.1 & 3.2 & 3.7 & 9.1 & 5.7 & 6.8 & 5.8 & 4.0 & 4.7 \\
\hline 27 & -- & -- & -- & 5.3 & 3.4 & 3.8 & 6.4 & 4.3 & 5.2 & 5.9 & 3.8 & 4.4 \\
\hline 28 & -- & -- & -- & 4.7 & 3.5 & 3.9 & 6.0 & 4.6 & 5.2 & 4.8 & 3.5 & 3.9 \\
\hline 29 & -- & -- & -- & 4.7 & 3.4 & 3.9 & 9.4 & 5.7 & 7.4 & 8.6 & 3.3 & 4.3 \\
\hline 30 & 2.9 & 1.7 & 2.1 & 4.6 & 3.4 & 3.8 & 18 & 8.0 & 13 & 5.7 & 3.3 & 3.9 \\
\hline 31 & 3.1 & 1.5 & 1.9 & -- & -- & -- & 31 & 13 & 20 & -- & -- & -- \\
\hline Month $^{1}$ & 3.1 & 1.5 & 2.0 & 7.8 & 1.4 & 2.5 & 49 & 2.8 & 8.1 & 47 & 3.3 & 9.0 \\
\hline
\end{tabular}


Table 7. Seasonal daily maximum, minimum, and mean turbidity, with monthly summary statistics, at Warm Springs Creek at Warm Springs, Montana (12323770), March through September 2017.-Continued

[Turbidity values are based on near-infrared monochrome light emitted at wavelengths of 780 to 900 nanometers with a detection angle of 90 plus or minus 2.5 degrees to incident beam, reported in formazin nephelometric units (FNU). --, no data]

\begin{tabular}{|c|c|c|c|c|c|c|c|c|c|}
\hline \multirow{2}{*}{ Day } & Maximum & Minimum & Mean & Maximum & Minimum & Mean & Maximum & Minimum & Mean \\
\hline & \multicolumn{3}{|c|}{ July } & \multicolumn{3}{|c|}{ August } & \multicolumn{3}{|c|}{ September } \\
\hline 1 & 5.0 & 3.1 & 3.8 & 2.6 & 1.1 & 1.6 & 3.1 & 1.3 & 2.1 \\
\hline 2 & -- & -- & -- & 2.4 & 1.2 & 1.5 & 2.6 & 1.1 & 1.9 \\
\hline 3 & -- & -- & -- & 2.3 & 0.8 & 1.4 & 3.2 & 1.1 & 1.7 \\
\hline 4 & -- & -- & -- & 2.6 & 0.8 & 1.3 & 3.0 & 1.0 & 1.5 \\
\hline 5 & -- & -- & -- & 2.1 & 0.8 & 1.2 & 2.7 & 0.9 & 1.6 \\
\hline 6 & -- & -- & -- & 1.8 & 0.8 & 1.2 & 2.3 & 0.9 & 1.4 \\
\hline 7 & 13 & 2.6 & 3.8 & 2.1 & 0.7 & 1.2 & 2.9 & 0.6 & 1.2 \\
\hline 8 & 3.5 & 2.3 & 2.9 & -- & -- & -- & -- & -- & -- \\
\hline 9 & 3.6 & 2.3 & 2.8 & -- & -- & -- & -- & -- & -- \\
\hline 10 & -- & -- & -- & 3.2 & 1.0 & 1.7 & -- & -- & -- \\
\hline 11 & 4.5 & 2.2 & 2.9 & 2.6 & 1.0 & 1.5 & 2.8 & 1.0 & 1.4 \\
\hline 12 & 3.5 & 2.0 & 2.5 & 2.4 & 0.9 & 1.4 & 2.5 & 1.0 & 1.5 \\
\hline 13 & 4.0 & 1.7 & 2.5 & 2.2 & 1.0 & 1.4 & 2.6 & 0.9 & 1.6 \\
\hline 14 & 3.7 & 1.8 & 2.5 & 3.3 & 0.8 & 1.8 & 3.2 & 1.0 & 1.7 \\
\hline 15 & 980 & 1.8 & 22 & 4.9 & 0.8 & 1.5 & 3.8 & 1.0 & 1.8 \\
\hline 16 & 1,070 & 6.2 & 91 & 2.3 & 0.9 & 1.5 & 2.2 & 0.7 & 1.3 \\
\hline 17 & 7.5 & 4.2 & 5.6 & 2.0 & 0.8 & 1.3 & 2.2 & 0.6 & 1.1 \\
\hline 18 & 5.8 & 3.3 & 4.1 & 2.0 & 0.7 & 1.2 & -- & -- & -- \\
\hline 19 & 4.9 & 2.7 & 3.6 & 2.7 & 0.7 & 1.3 & -- & -- & -- \\
\hline 20 & 5.6 & 2.6 & 3.8 & 2.0 & 0.7 & 1.2 & -- & -- & -- \\
\hline 21 & 4.8 & 2.1 & 2.9 & 2.3 & 0.7 & 1.3 & -- & -- & -- \\
\hline 22 & 4.2 & 1.6 & 2.6 & 3.9 & 1.2 & 2.2 & -- & -- & -- \\
\hline 23 & 4.0 & 1.6 & 2.4 & 4.1 & 0.9 & 1.6 & -- & -- & -- \\
\hline 24 & 5.1 & 2.3 & 2.8 & 1.9 & 0.7 & 1.2 & -- & -- & -- \\
\hline 25 & 5.1 & 2.0 & 3.0 & 2.2 & 0.6 & 1.1 & 2.4 & 0.6 & 1.2 \\
\hline 26 & 10 & 2.4 & 3.5 & 1.9 & 0.5 & 1.0 & 4.1 & 0.7 & 1.7 \\
\hline 27 & 5.9 & 2.5 & 3.6 & -- & -- & -- & 6.1 & 0.9 & 1.7 \\
\hline 28 & 3.3 & 1.5 & 2.2 & -- & -- & -- & 2.3 & 0.7 & 1.2 \\
\hline 29 & 2.9 & 1.3 & 1.9 & -- & -- & -- & 2.0 & 0.5 & 1.0 \\
\hline 30 & 2.8 & 1.3 & 1.8 & 1.9 & 0.5 & 0.9 & 1.9 & 0.6 & 1.1 \\
\hline 31 & 2.6 & 1.3 & 1.7 & 3.8 & 0.7 & 1.6 & -- & -- & -- \\
\hline Month $^{1}$ & 1,070 & 1.3 & 7.3 & 4.9 & 0.5 & 1.4 & 6.1 & 0.5 & 1.5 \\
\hline
\end{tabular}

${ }^{1}$ For months with missing daily values, the means are calculated using available values. 
Table 8. Seasonal daily maximum, minimum, and mean turbidity, with monthly summary statistics, at Lost Creek near Anaconda, Montana (12323840), March through September 2017.

[Turbidity values are based on near-infrared monochrome light emitted at wavelengths of 780 to 900 nanometers with a detection angle of 90 plus or minus 2.5 degrees to incident beam, reported in formazin nephelometric units (FNU). --, no data]

\begin{tabular}{|c|c|c|c|c|c|c|c|c|c|c|c|c|}
\hline \multirow{2}{*}{ Day } & Maximum & Minimum & Mean & Maximum & Minimum & Mean & Maximum & Minimum & Mean & Maximum & Minimum & Mean \\
\hline & \multicolumn{3}{|c|}{ March } & \multicolumn{3}{|c|}{ April } & \multicolumn{3}{|c|}{ May } & \multicolumn{3}{|c|}{ June } \\
\hline 1 & -- & -- & -- & 17 & 3.5 & 5.8 & 6.1 & 1.7 & 3.1 & 70 & 6.9 & 12 \\
\hline 3 & -- & -- & -- & 9.4 & 2.5 & 4.2 & 5.3 & 1.6 & 2.6 & 15 & 6.0 & 8.5 \\
\hline 4 & -- & -- & -- & 15 & 2.8 & 5.1 & 7.7 & 1.4 & 2.7 & 23 & 5.3 & 8.4 \\
\hline 6 & -- & -- & -- & 9.1 & 3.3 & 4.6 & 8.9 & 2.5 & 4.2 & 12 & 5.4 & 8.3 \\
\hline 7 & -- & -- & -- & 6.7 & 2.8 & 3.7 & 259 & 5.2 & 18 & 8.1 & 4.1 & 6.3 \\
\hline 8 & -- & -- & -- & 9.7 & 2.6 & 4.0 & 18 & 4.6 & 8.9 & 9.1 & 4.7 & 5.9 \\
\hline 9 & -- & -- & -- & 16 & 2.8 & 5.0 & 13 & 1.9 & 4.1 & 17 & 4.9 & 7.8 \\
\hline 12 & -- & -- & -- & 12 & 2.9 & 4.3 & 81 & 4.8 & 9.9 & 168 & 4.2 & 21 \\
\hline 13 & -- & -- & -- & 12 & 3.2 & 6.1 & 44 & 5.4 & 9.8 & 88 & 26 & 51 \\
\hline 14 & -- & -- & -- & 4.7 & 2.9 & 3.7 & 12 & 3.4 & 5.2 & 29 & 12 & 18 \\
\hline 15 & -- & -- & -- & 8.6 & 2.4 & 4.0 & 6.3 & 3.2 & 4.1 & 12 & 7.2 & 9.4 \\
\hline 16 & -- & -- & -- & 6.3 & 2.5 & 3.4 & 4.7 & 2.7 & 3.4 & 12 & 5.7 & 7.9 \\
\hline 17 & -- & -- & -- & 6.7 & 2.7 & 3.9 & 13 & 3.2 & 5.3 & 17 & 6.0 & 8.5 \\
\hline 18 & -- & -- & -- & -- & -- & -- & 23 & 2.4 & 4.9 & 14 & 5.4 & 7.1 \\
\hline 19 & -- & -- & -- & 7.7 & 2.7 & 3.5 & 4.1 & 1.4 & 2.6 & 13 & 4.6 & 6.8 \\
\hline 24 & -- & -- & -- & 6.4 & 2.5 & 4.1 & 46 & 5.8 & 11 & 8.7 & 1.7 & 3.1 \\
\hline 25 & -- & -- & -- & 6.5 & 2.1 & 3.5 & 21 & 6.2 & 9.9 & 9.0 & 2.4 & 3.5 \\
\hline 26 & -- & -- & -- & 8.9 & 2.8 & 4.2 & 13 & 4.3 & 6.2 & 6.7 & 2.7 & 3.5 \\
\hline 27 & -- & -- & -- & 107 & 3.3 & 11 & 28 & 3.8 & 6.7 & 6.2 & 1.6 & 3.4 \\
\hline 28 & -- & -- & -- & 24 & 4.4 & 12 & 12 & 2.8 & 4.4 & 4.0 & 1.4 & 2.5 \\
\hline 29 & -- & -- & -- & 25 & 2.7 & 4.6 & 8.1 & 3.4 & 4.9 & 5.2 & 1.8 & 3.3 \\
\hline 30 & 21 & 4.1 & 8.0 & 7.9 & 3.3 & 4.3 & 8.8 & 1.7 & 5.6 & 6.6 & 0.5 & 3.3 \\
\hline 31 & 11 & 3.6 & 5.5 & -- & -- & -- & 14 & 3.9 & 6.4 & -- & -- & -- \\
\hline Month ${ }^{1}$ & 21 & 3.6 & 6.8 & 107 & 2.1 & 4.8 & 259 & 1.4 & 5.6 & 168 & 0.5 & 9.0 \\
\hline
\end{tabular}


Table 8. Seasonal daily maximum, minimum, and mean turbidity, with monthly summary statistics, at Lost Creek near Anaconda, Montana (12323840), March through September 2017.-Continued

[Turbidity values are based on near-infrared monochrome light emitted at wavelengths of 780 to 900 nanometers with a detection angle of 90 plus or minus 2.5 degrees to incident beam, reported in formazin nephelometric units (FNU). --, no data]

\begin{tabular}{|c|c|c|c|c|c|c|c|c|c|}
\hline \multirow{2}{*}{ Day } & Maximum & Minimum & Mean & Maximum & Minimum & Mean & Maximum & Minimum & Mean \\
\hline & \multicolumn{3}{|c|}{ July } & \multicolumn{3}{|c|}{ August } & \multicolumn{3}{|c|}{ September } \\
\hline 1 & 4.3 & 1.4 & 2.2 & 3.7 & 2.4 & 2.9 & 2.4 & 0.5 & 1.5 \\
\hline 2 & 4.9 & 1.9 & 2.6 & 75 & 2.2 & 6.9 & 2.0 & 1.0 & 1.6 \\
\hline 3 & 4.8 & 1.8 & 2.6 & 3.9 & 2.2 & 2.8 & 2.2 & 0.5 & 1.1 \\
\hline 4 & 3.3 & 1.1 & 2.2 & 91 & 2.2 & 8.5 & 2.4 & 0.5 & 1.1 \\
\hline 5 & 3.9 & 1.9 & 2.5 & 7.1 & 4.1 & 5.4 & 3.3 & 0.5 & 1.1 \\
\hline 6 & 3.3 & 1.8 & 2.4 & 8.9 & 3.4 & 4.1 & 2.2 & 0.5 & 0.9 \\
\hline 7 & 4.3 & 1.4 & 2.2 & 6.6 & 3.3 & 3.9 & 1.9 & 0.5 & 1.1 \\
\hline 8 & 3.4 & 1.3 & 1.9 & 5.4 & 3.0 & 3.6 & -- & -- & -- \\
\hline 9 & 4.4 & 1.2 & 2.1 & 5.7 & 3.2 & 3.7 & -- & -- & -- \\
\hline 10 & 2.6 & 1.3 & 1.8 & 4.5 & 2.8 & 3.3 & -- & -- & -- \\
\hline 11 & 3.9 & 1.0 & 2.0 & 5.8 & 3.1 & 3.8 & -- & -- & -- \\
\hline 12 & 3.0 & 1.9 & 2.2 & 13 & 3.3 & 4.1 & -- & -- & -- \\
\hline 13 & 3.3 & 2.0 & 2.3 & 5.4 & 3.3 & 3.9 & -- & -- & -- \\
\hline 14 & 3.3 & 1.6 & 2.3 & 4.4 & 3.0 & 3.5 & -- & -- & -- \\
\hline 15 & 1,080 & 1.8 & 148 & 6.1 & 3.1 & 3.7 & -- & -- & -- \\
\hline 16 & 125 & 8.6 & 18 & 5.3 & 2.9 & 3.7 & -- & -- & -- \\
\hline 17 & 28 & 4.0 & 7.8 & 5.5 & 3.2 & 3.7 & -- & -- & -- \\
\hline 18 & 5.9 & 2.9 & 4.0 & 4.5 & 3.1 & 3.6 & -- & -- & -- \\
\hline 19 & 15 & 2.1 & 5.6 & 4.9 & 3.1 & 3.6 & -- & -- & -- \\
\hline 20 & 5.6 & 1.2 & 3.4 & 4.6 & 2.9 & 3.5 & -- & -- & -- \\
\hline 21 & 5.2 & 2.7 & 3.2 & 5.7 & 3.2 & 3.9 & -- & -- & -- \\
\hline 22 & 6.0 & 2.0 & 2.7 & 5.8 & 3.1 & 4.0 & -- & -- & -- \\
\hline 23 & 6.1 & 2.0 & 2.7 & 6.4 & 2.7 & 3.7 & -- & -- & -- \\
\hline 24 & 3.4 & 1.9 & 2.4 & 3.8 & 2.3 & 2.9 & 8.3 & 0.5 & 1.1 \\
\hline 25 & 4.3 & 1.9 & 2.3 & 5.8 & 2.2 & 2.7 & 5.5 & 0.7 & 1.2 \\
\hline 26 & 3.1 & 1.4 & 2.1 & 3.5 & 2.2 & 2.6 & 2.4 & 1.1 & 1.4 \\
\hline 27 & 3.0 & 1.5 & 1.9 & 2.6 & 2.0 & 2.3 & 2.2 & 1.5 & 1.8 \\
\hline 28 & 5.2 & 1.3 & 1.8 & 3.3 & 1.9 & 2.2 & 3.0 & 1.7 & 2.0 \\
\hline 29 & 3.8 & 1.8 & 2.0 & 3.5 & 1.8 & 2.1 & 4.4 & 2.1 & 2.3 \\
\hline 30 & 6.1 & 1.7 & 2.3 & 2.6 & 1.2 & 1.8 & 2.9 & 2.1 & 2.2 \\
\hline 31 & 6.0 & 2.3 & 3.2 & 2.1 & 1.1 & 1.5 & -- & -- & -- \\
\hline Month $^{1}$ & 1,080 & 1.0 & 7.9 & 91 & 1.1 & 3.6 & 8.3 & 0.5 & 1.5 \\
\hline
\end{tabular}

${ }^{1}$ For months with missing daily values, the means are calculated using available values. 


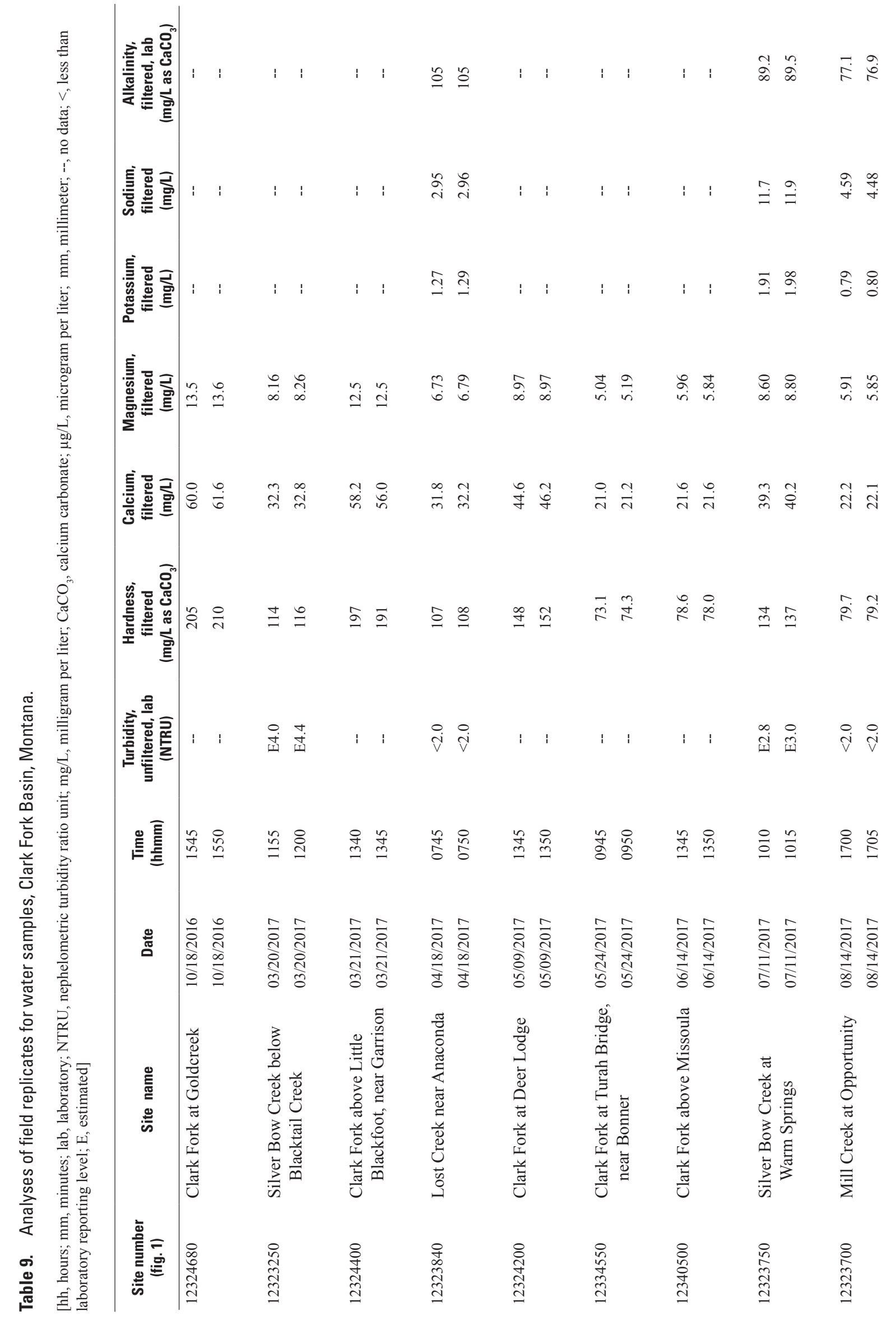




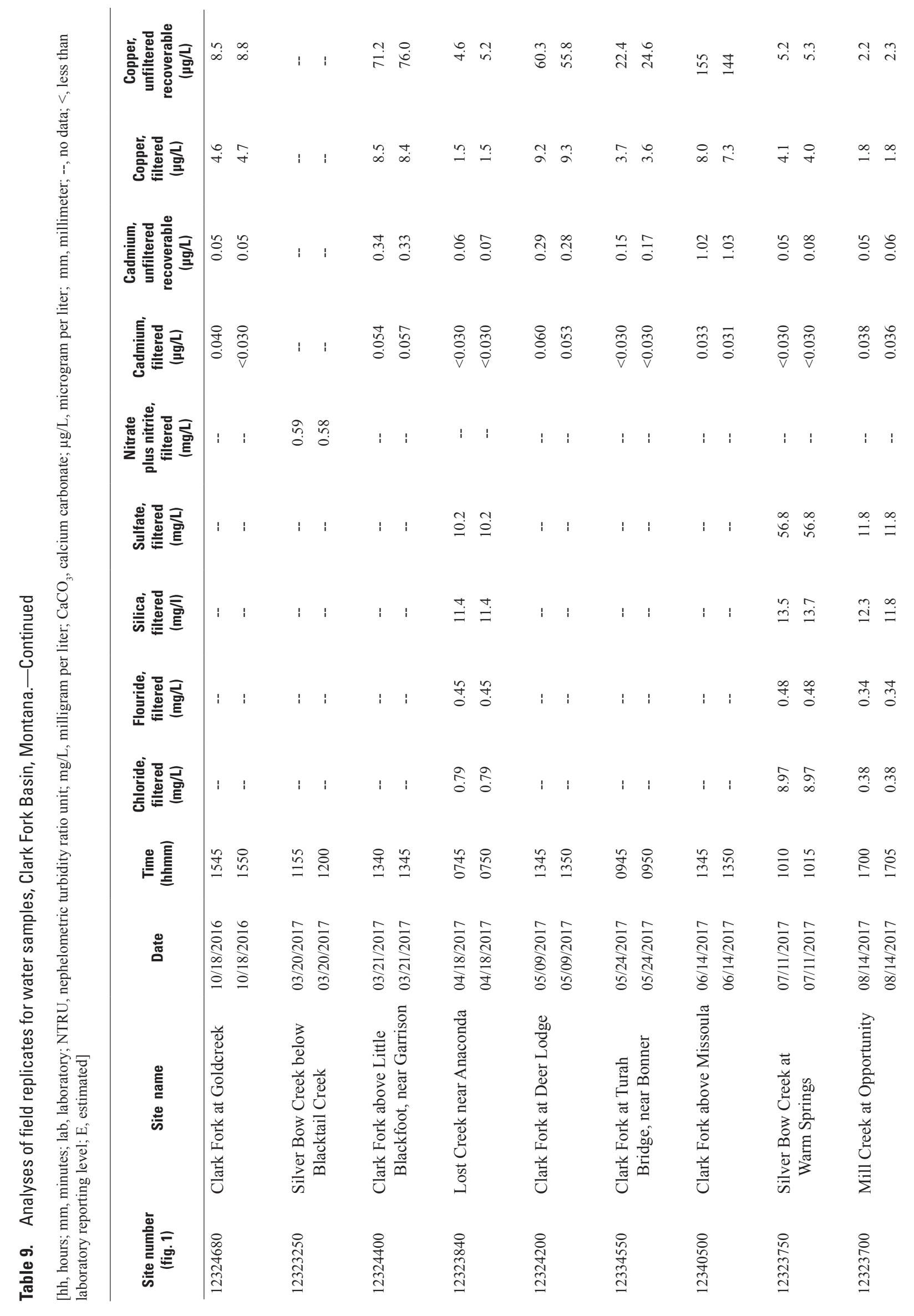




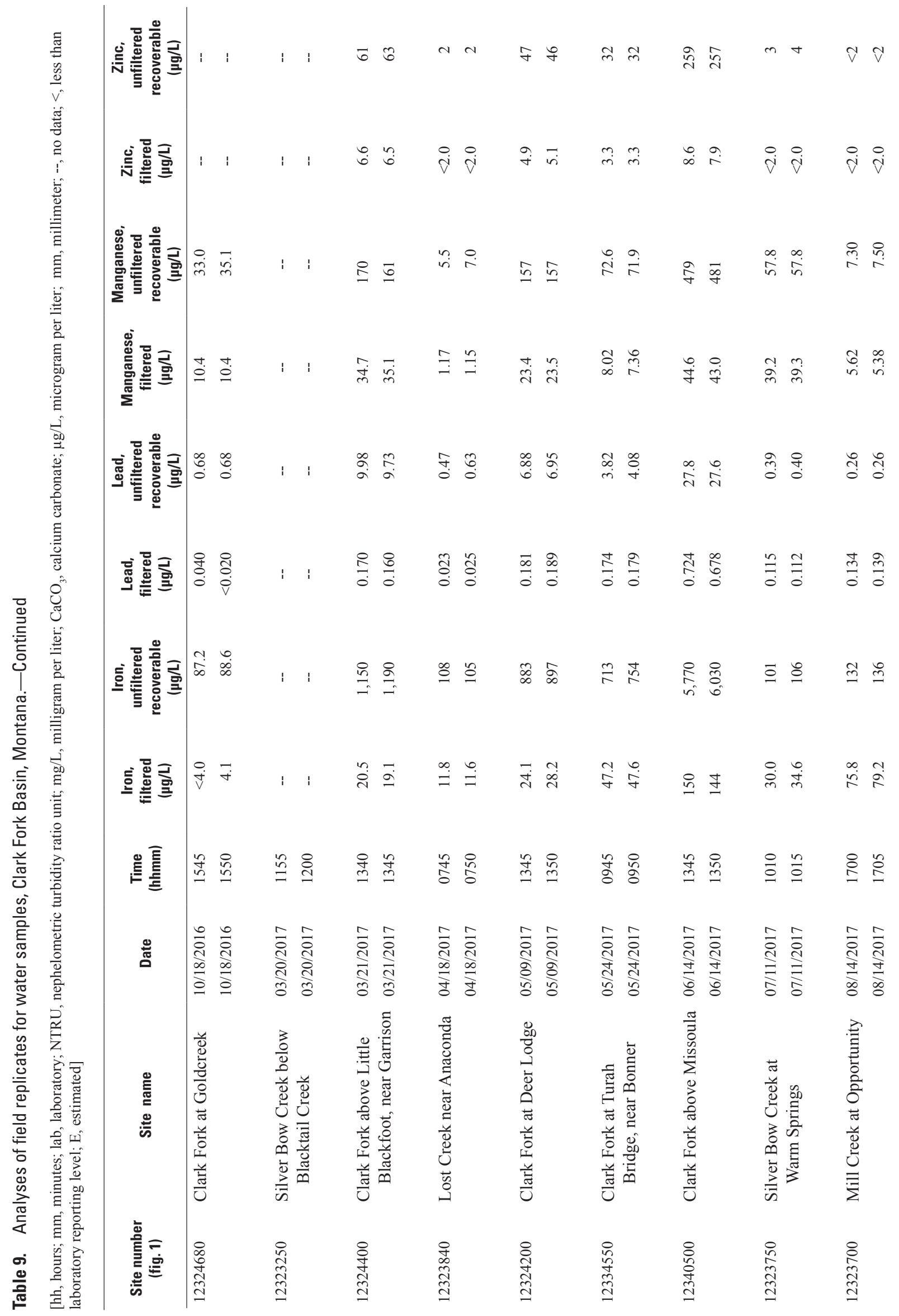




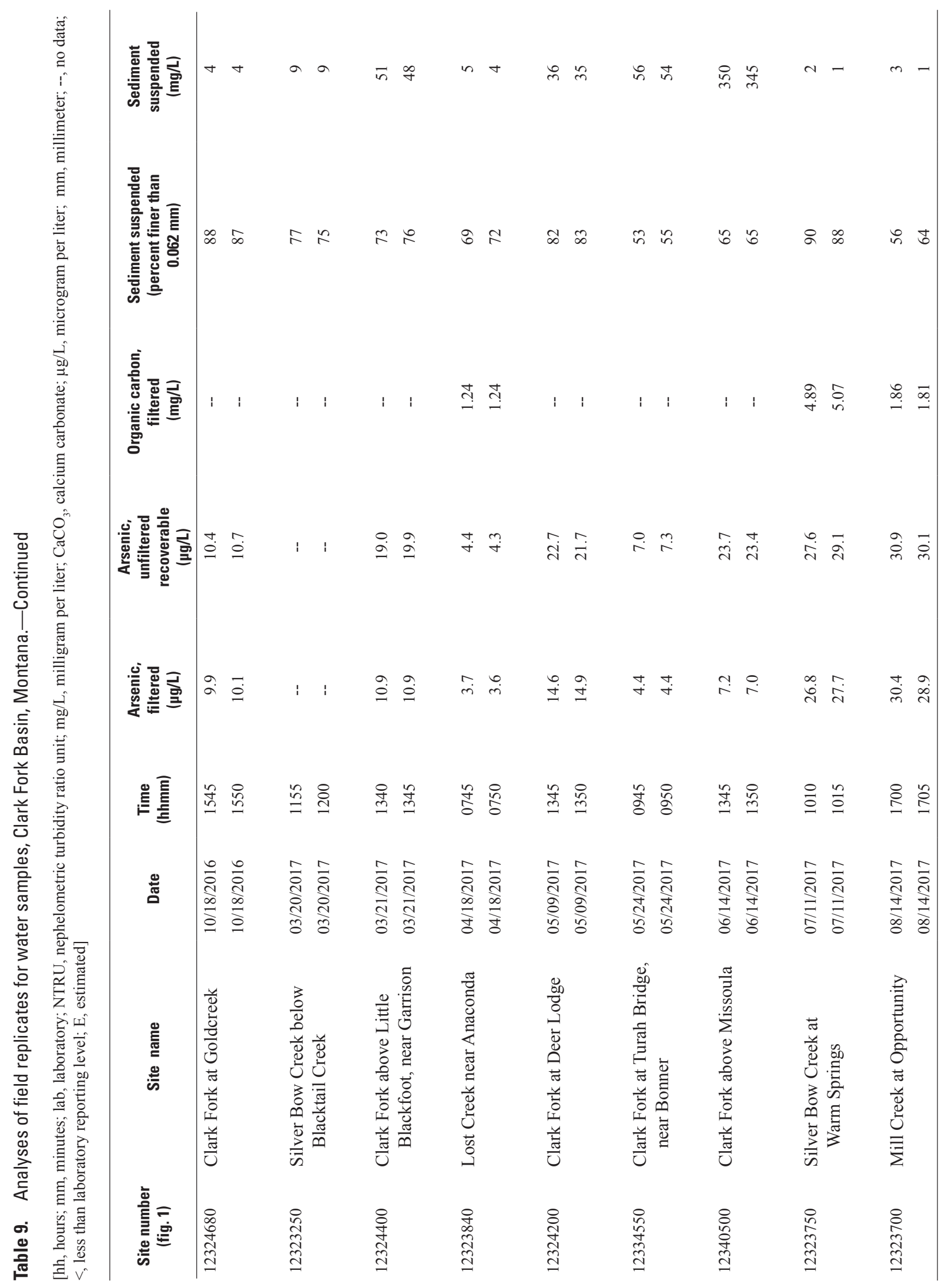


Table 10. Precision of analyses of field replicates for stream water samples, Clark Fork Basin, Montana.

[lab, laboratory; NTRU, nephelometric turbidity ratio unit; mg/L, milligram per liter; $\mu \mathrm{g} / \mathrm{L}$, microgram per liter; mm, millimeter]

\begin{tabular}{|c|c|c|c|c|}
\hline Constituent and reporting unit & $\begin{array}{l}\text { Number of } \\
\text { replicate pairs }\end{array}$ & $\begin{array}{l}\text { Standard deviation' } \\
\quad \text { (listed units) }\end{array}$ & $\begin{array}{l}\text { Relative standard } \\
\text { deviation } \\
\text { (percent) }\end{array}$ & $\begin{array}{c}\text { Within limitss of } \\
\text { data-quality objective }\end{array}$ \\
\hline Turbidity, unfiltered, lab, NTRU & 4 & 0.16 & 7.0 & Yes \\
\hline Calcium, filtered, mg/L & 9 & 0.79 & 2.1 & Yes \\
\hline Magnesium, filtered, mg/L & 9 & 0.08 & 0.91 & Yes \\
\hline Potassium, filtered, mg/L & 3 & 0.03 & 2.2 & Yes \\
\hline Sodium, filtered, mg/L & 3 & 0.09 & 1.5 & Yes \\
\hline Alkalinity, filtered, lab, mg/L & 3 & 0.15 & 0.16 & Yes \\
\hline Chloride, filtered, mg/L & 3 & 0.00 & 0.00 & Yes \\
\hline Fluoride, filtered, mg/L & 3 & 0.00 & 0.00 & Yes \\
\hline Silica, filtered, $\mathrm{mg} / \mathrm{L}$ & 3 & 0.22 & 1.8 & Yes \\
\hline Sulfate, filtered, $\mathrm{mg} / \mathrm{L}$ & 3 & 0.00 & 0.00 & Yes \\
\hline Cadmium, filtered, $\mu \mathrm{g} / \mathrm{L}$ & 8 & 0.01 & 21 & $\mathrm{No}^{3}$ \\
\hline Cadmium, unfiltered recoverable, $\mu \mathrm{g} / \mathrm{L}$ & 8 & 0.01 & 4.2 & Yes \\
\hline Copper, filtered, $\mu \mathrm{g} / \mathrm{L}$ & 8 & 0.18 & 3.6 & Yes \\
\hline Copper, unfiltered recoverable, $\mu \mathrm{g} / \mathrm{L}$ & 8 & 3.3 & 8.0 & Yes \\
\hline Iron, filtered, $\mu \mathrm{g} / \mathrm{L}$ & 8 & 2.4 & 5.3 & Yes \\
\hline Iron, unfiltered recoverable, $\mu \mathrm{g} / \mathrm{L}$ & 8 & 66 & 5.8 & Yes \\
\hline Lead, filtered, $\mu \mathrm{g} / \mathrm{L}$ & 8 & 0.01 & 7.5 & Yes \\
\hline Lead, unfiltered recoverable, $\mu \mathrm{g} / \mathrm{L}$ & 8 & 0.11 & 1.8 & Yes \\
\hline Manganese, filtered, $\mu \mathrm{g} / \mathrm{L}$ & 8 & 0.45 & 2.2 & Yes \\
\hline Manganese, unfiltered recoverable, $\mu \mathrm{g} / \mathrm{L}$ & 8 & 2.4 & 2.0 & Yes \\
\hline Zinc, filtered, $\mu \mathrm{g} / \mathrm{L}$ & 7 & 0.20 & 5.3 & Yes \\
\hline Zinc, unfiltered recoverable, $\mu \mathrm{g} / \mathrm{L}$ & 7 & 0.85 & 1.5 & Yes \\
\hline Arsenic, filtered, $\mu \mathrm{g} / \mathrm{L}$ & 8 & 0.45 & 3.3 & Yes \\
\hline Arsenic, unfiltered recoverable, $\mu \mathrm{g} / \mathrm{L}$ & 8 & 0.56 & 3.1 & Yes \\
\hline Organic carbon, filtered, mg/L & 3 & 0.08 & 2.8 & Yes \\
\hline Sediment, suspended, percent finer than $0.062 \mathrm{~mm}$ & 9 & 2.3 & 3.2 & Yes \\
\hline Sediment, suspended, mg/L & 9 & 1.6 & 2.5 & Yes \\
\hline
\end{tabular}

${ }^{1}$ Standard deviation is calculated using one-half of the laboratory reporting level for censored values (less than the laboratory reporting level).

${ }^{2}$ The data-quality objective for an acceptable level of precision is a maximum relative standard deviation of 20 percent for field replicate analyses (table 3).

${ }^{3}$ Exceedence of the data-quality objective resulted from a statistical artifact of calculating the difference between one replicate sample pair for which one value is less than the laboratory reporting level. Because analytical variation, in percent, can be large at very low concentrations, the precision may not be representative of analytical performance at detectable concentrations. 
Table 11. Precision of analyses of laboratory replicates for stream water samples, Clark Fork Basin, Montana.

$[\mathrm{mg} / \mathrm{L}$, milligram per liter; $\mu \mathrm{g} / \mathrm{L}$, microgram per liter]

\begin{tabular}{|c|c|c|c|c|}
\hline Constituent and reporting unit & $\begin{array}{l}\text { Number of } \\
\text { replicate pairs }\end{array}$ & $\begin{array}{l}\text { Standard deviation, } \\
\text { in listed units }\end{array}$ & $\begin{array}{c}\text { Relative standard deviation, in } \\
\text { percent }\end{array}$ & $\begin{array}{l}\text { Within limits }{ }^{1} \text { of } \\
\text { data-quality objective }\end{array}$ \\
\hline Calcium, filtered, mg/L & 7 & 0.22 & 0.65 & Yes \\
\hline Magnesium, filtered, mg/L & 7 & 0.04 & 0.58 & Yes \\
\hline Cadmium, filtered, $\mu \mathrm{g} / \mathrm{L}$ & 8 & 0.00 & 10 & Yes \\
\hline Cadmium, unfiltered recoverable, $\mu \mathrm{g} / \mathrm{L}$ & 8 & 0.00 & 1.94 & Yes \\
\hline Copper, filtered, $\mu \mathrm{g} / \mathrm{L}$ & 8 & 0.07 & 1.37 & Yes \\
\hline Iron, filtered, $\mu \mathrm{g} / \mathrm{L}$ & 7 & 1.4 & 2.60 & Yes \\
\hline Iron, unfiltered recoverable, $\mu \mathrm{g} / \mathrm{L}$ & 8 & 7.8 & 0.67 & Yes \\
\hline Lead, filtered, $\mu \mathrm{g} / \mathrm{L}$ & 8 & 0.00 & 1.33 & Yes \\
\hline Lead, unfiltered recoverable, $\mu \mathrm{g} / \mathrm{L}$ & 8 & 0.07 & 1.14 & Yes \\
\hline Zinc, unfiltered recoverable, $\mu \mathrm{g} / \mathrm{L}$ & 8 & 1.1 & 2.21 & Yes \\
\hline Arsenic, filtered, $\mu \mathrm{g} / \mathrm{L}$ & 8 & 0.14 & 1.07 & Yes \\
\hline Arsenic, unfiltered recoverable, $\mu \mathrm{g} / \mathrm{L}$ & 8 & 0.22 & 1.21 & Yes \\
\hline
\end{tabular}

${ }^{1}$ The data-quality objective for an acceptable level of precision is a maximum relative standard deviation of 20 percent for laboratory replicate analyses (table 3).

Table 12. Recovery efficiency for analyses of laboratory-spiked deionized-water blank samples.

$[\mu \mathrm{g} / \mathrm{L}$, microgram per liter]

\begin{tabular}{|c|c|c|c|c|}
\hline Constituent and reporting unit & $\begin{array}{l}\text { Number of } \\
\text { samples }\end{array}$ & $\begin{array}{l}\text { 95-percent confidence } \\
\text { interval for spike recovery, } \\
\text { in percent }\end{array}$ & $\begin{array}{c}\text { Mean spike recovery, } \\
\text { in percent }\end{array}$ & $\begin{array}{c}\text { Within limits' of } \\
\text { data-quality objective }\end{array}$ \\
\hline Cadmium, filtered, $\mu \mathrm{g} / \mathrm{L}$ & 5 & $94.0-122$ & 108 & Yes \\
\hline Copper, filtered, $\mu \mathrm{g} / \mathrm{L}$ & 5 & $87.3-117$ & 102 & Yes \\
\hline Copper, unfiltered recoverable, $\mu \mathrm{g} / \mathrm{L}$ & 5 & $99.8-114$ & 107 & Yes \\
\hline Iron, unfiltered recoverable, $\mu \mathrm{g} / \mathrm{L}$ & 5 & $99.4-107$ & 103 & Yes \\
\hline Lead, filtered, $\mu \mathrm{g} / \mathrm{L}$ & 5 & $53.4-110$ & 81.5 & $\mathrm{No}^{2}$ \\
\hline Lead, unfiltered recoverable, $\mu \mathrm{g} / \mathrm{L}$ & 5 & $95.3-103$ & 99.2 & Yes \\
\hline Manganese, filtered, $\mu \mathrm{g} / \mathrm{L}$ & 5 & $88.9-104$ & 96.3 & Yes \\
\hline Manganese, unfiltered recoverable, $\mu \mathrm{g} / \mathrm{L}$ & 5 & $96.4-106$ & 101 & Yes \\
\hline Arsenic, filtered, $\mu \mathrm{g} / \mathrm{L}$ & 5 & $93.6-103$ & 98.5 & Yes \\
\hline Arsenic, unfiltered recoverable, $\mu \mathrm{g} / \mathrm{L}$ & 5 & $96.0-102$ & 99.1 & Yes \\
\hline
\end{tabular}

${ }^{1}$ The data-quality objective for acceptable bias is a maximum deviation of 25 percent from a theoretical 100-percent recovery (table 3 ).

${ }^{2}$ Exceedance of the data-quality objective resulted from two samples having low recoveries of 60.0 and 59.8 percent. 
54 Water-Quality, Bed-Sediment, and Biological Data and Statistical Summaries of Data, Clark Fork Basin, Montana

Table 13. Recovery efficiency for analyses of laboratory-spiked stream samples, Clark Fork Basin, Montana.

$[\mu \mathrm{g} / \mathrm{L}$, microgram per liter]

\begin{tabular}{|c|c|c|c|c|}
\hline Constituent and reporting unit & $\begin{array}{l}\text { Number of } \\
\text { samples }\end{array}$ & $\begin{array}{l}\text { 95-percent confidence } \\
\text { interval for spike recovery, } \\
\text { in percent }\end{array}$ & $\begin{array}{l}\text { Mean spike recovery, } \\
\text { in percent }\end{array}$ & $\begin{array}{c}\text { Within limits' of } \\
\text { data-quality objective }\end{array}$ \\
\hline Cadmium, filtered, $\mu \mathrm{g} / \mathrm{L}$ & 5 & $85.6-108$ & 96.6 & Yes \\
\hline Copper, filtered, $\mu \mathrm{g} / \mathrm{L}$ & 5 & $90.3-108$ & 99.2 & Yes \\
\hline Copper, unfiltered recoverable, $\mu \mathrm{g} / \mathrm{L}$ & 5 & $79.0-106$ & 92.3 & Yes \\
\hline Iron, unfiltered recoverable, $\mu \mathrm{g} / \mathrm{L}$ & 5 & $79.3-96.3$ & 87.8 & Yes \\
\hline Lead, filtered, $\mu \mathrm{g} / \mathrm{L}$ & 5 & $91.9-105$ & 98.3 & Yes \\
\hline Lead, unfiltered recoverable, $\mu \mathrm{g} / \mathrm{L}$ & 5 & $86.2-101$ & 93.4 & Yes \\
\hline Manganese, filtered, $\mu \mathrm{g} / \mathrm{L}$ & 5 & $88.0-106$ & 97.1 & Yes \\
\hline Manganese, unfiltered recoverable, $\mu \mathrm{g} / \mathrm{L}$ & 5 & $92.2-105$ & 98.5 & Yes \\
\hline Arsenic, unfiltered recoverable, $\mu \mathrm{g} / \mathrm{L}$ & 5 & $43.4-128$ & 85.9 & $\mathrm{No}^{3}$ \\
\hline
\end{tabular}

${ }^{1}$ The data-quality objective for acceptable bias is a maximum deviation of 25 percent from a theoretical 100-percent recovery (table 3 ).

${ }^{2}$ Exceedance of the data-quality objective resulted from one sample having a recovery of 65.5 percent. When data from this one spiked-sample set are removed from the 95-percent confidence interval calculation, filtered arsenic meets the data-quality objective limit (78.1-108 percent).

${ }^{3}$ Exceedance of the data-quality objective resulted from one sample having a recovery of 29.6 percent. When data from this one spiked-sample set are removed from the 95-percent confidence interval calculation, filtered arsenic meets the data-quality objective limit (75.2-125 percent). 


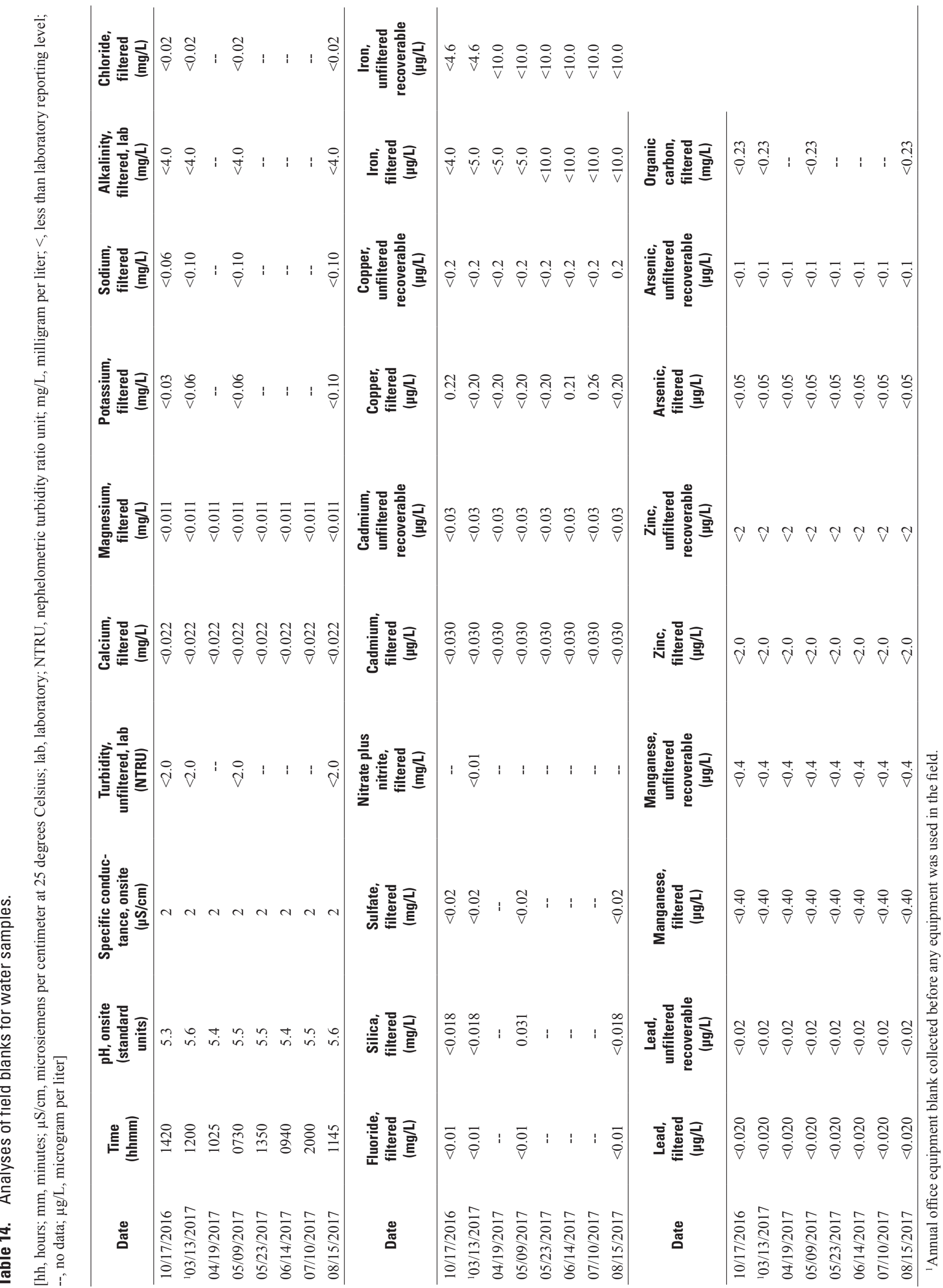




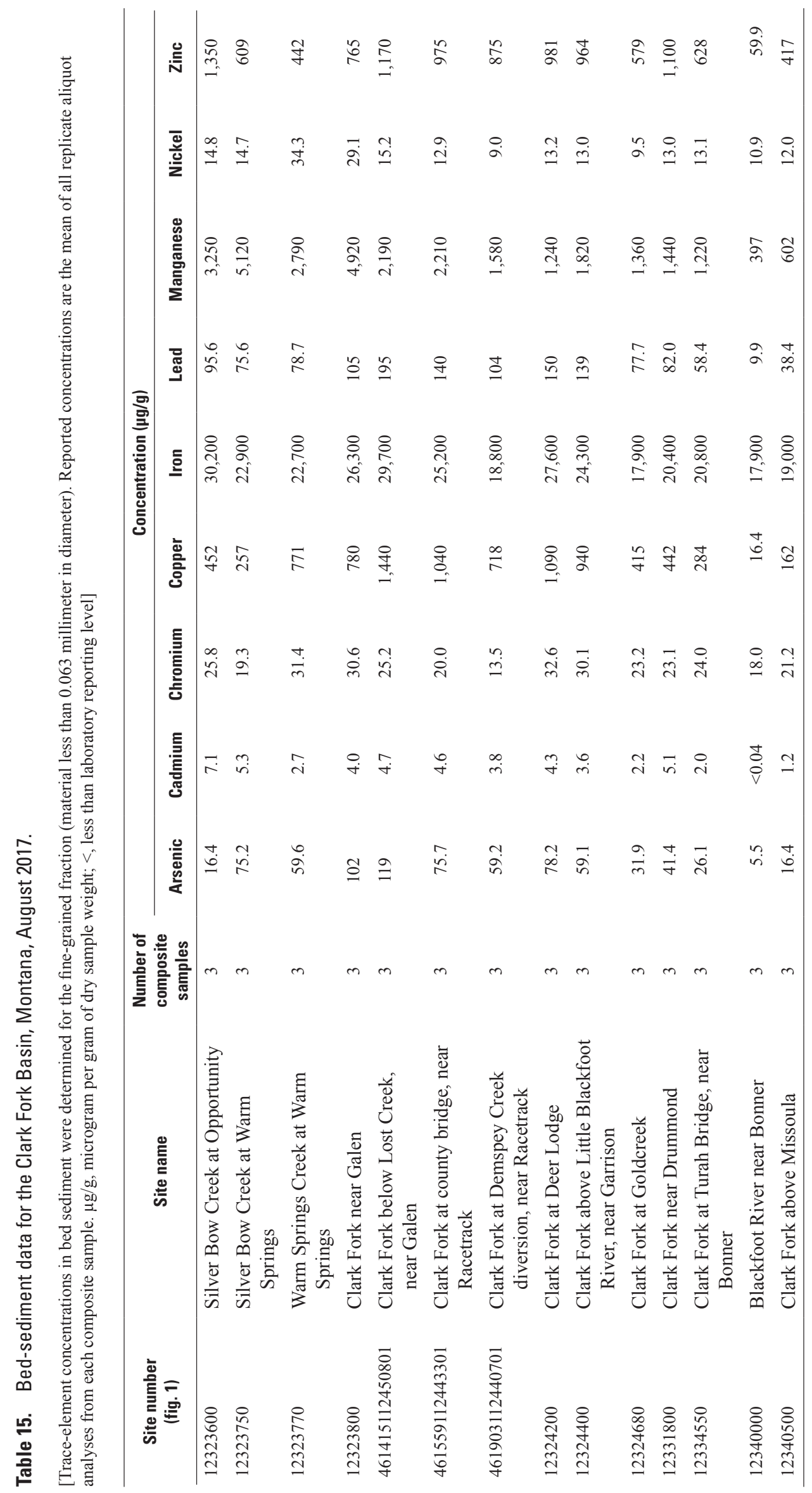


Table 16. Recovery efficiency for analyses of standard reference materials for bed-sediment samples.

[Dilution ratio is the proportion of initial volume of concentrated nitric acid used as a digesting reagent to final volume of solution after addition of $0.6 \mathrm{~N}$ (normal) hydrochloric acid used for reconstituting dried residue. $\mu \mathrm{g} / \mathrm{g}$, microgram per gram of dry sample weight; SRM, standard reference material (agricultural soils)]

\begin{tabular}{|c|c|c|c|c|c|}
\hline Constituent & $\begin{array}{l}\text { Number of } \\
\text { analyses }\end{array}$ & $\begin{array}{c}\text { Dilution } \\
\text { ratio }\end{array}$ & $\begin{array}{c}\text { Certified } \\
\text { concentration } \\
(\mu \mathrm{g} / \mathrm{g})\end{array}$ & $\begin{array}{c}\text { Mean SRM } \\
\text { recovery } \\
\text { (percent) }\end{array}$ & $\begin{array}{l}\text { 95-percent confidence } \\
\text { interval for SRM recovery } \\
\text { (percent) }\end{array}$ \\
\hline \multicolumn{6}{|c|}{ SRM sample 2709a } \\
\hline Arsenic & 10 & $1: 10$ & 10.5 & 50.2 & $47.1-53.3$ \\
\hline Cadmium & 10 & $1: 10$ & 0.371 & 53.6 & $51.7-55.5$ \\
\hline Chromium & 10 & $1: 10$ & 130 & 67.6 & $66.1-69.0$ \\
\hline Copper & 10 & $1: 10$ & 33.9 & 76.4 & $74.8-78.0$ \\
\hline Iron & 10 & $1: 10$ & 33,600 & 87.4 & $86.6-88.3$ \\
\hline Lead & 10 & $1: 10$ & 17.3 & 45.0 & $43.9-46.1$ \\
\hline Manganese & 10 & $1: 10$ & 529 & 84.9 & $83.6-86.3$ \\
\hline Nickel & 10 & $1: 10$ & 85 & 87.7 & $87.2-88.1$ \\
\hline Zinc & 10 & $1: 10$ & 103 & 90.0 & $89.5-90.5$ \\
\hline \multicolumn{6}{|c|}{ SRM sample $2711 \mathrm{a}$} \\
\hline Arsenic & 10 & $1: 10$ & 107 & 89.7 & $86.8-92.5$ \\
\hline Cadmium & 10 & $1: 10$ & 54.1 & 97.7 & $96.6-99.0$ \\
\hline Chromium & 10 & $1: 10$ & 52.3 & 55.6 & $54.3-56.9$ \\
\hline Copper & 10 & $1: 10$ & 140 & 91.9 & $90.6-93.2$ \\
\hline Iron & 10 & $1: 10$ & 28,200 & 83.7 & $82.6-84.8$ \\
\hline Lead & 10 & $1: 10$ & 1,400 & 97.4 & $96.5-98.3$ \\
\hline Manganese & 10 & $1: 10$ & 675 & 79.3 & $77.7-80.9$ \\
\hline Nickel & 10 & $1: 10$ & 21.7 & 88.0 & $87.1-88.9$ \\
\hline Zinc & 10 & $1: 10$ & 414 & 94.6 & $93.6-95.6$ \\
\hline
\end{tabular}




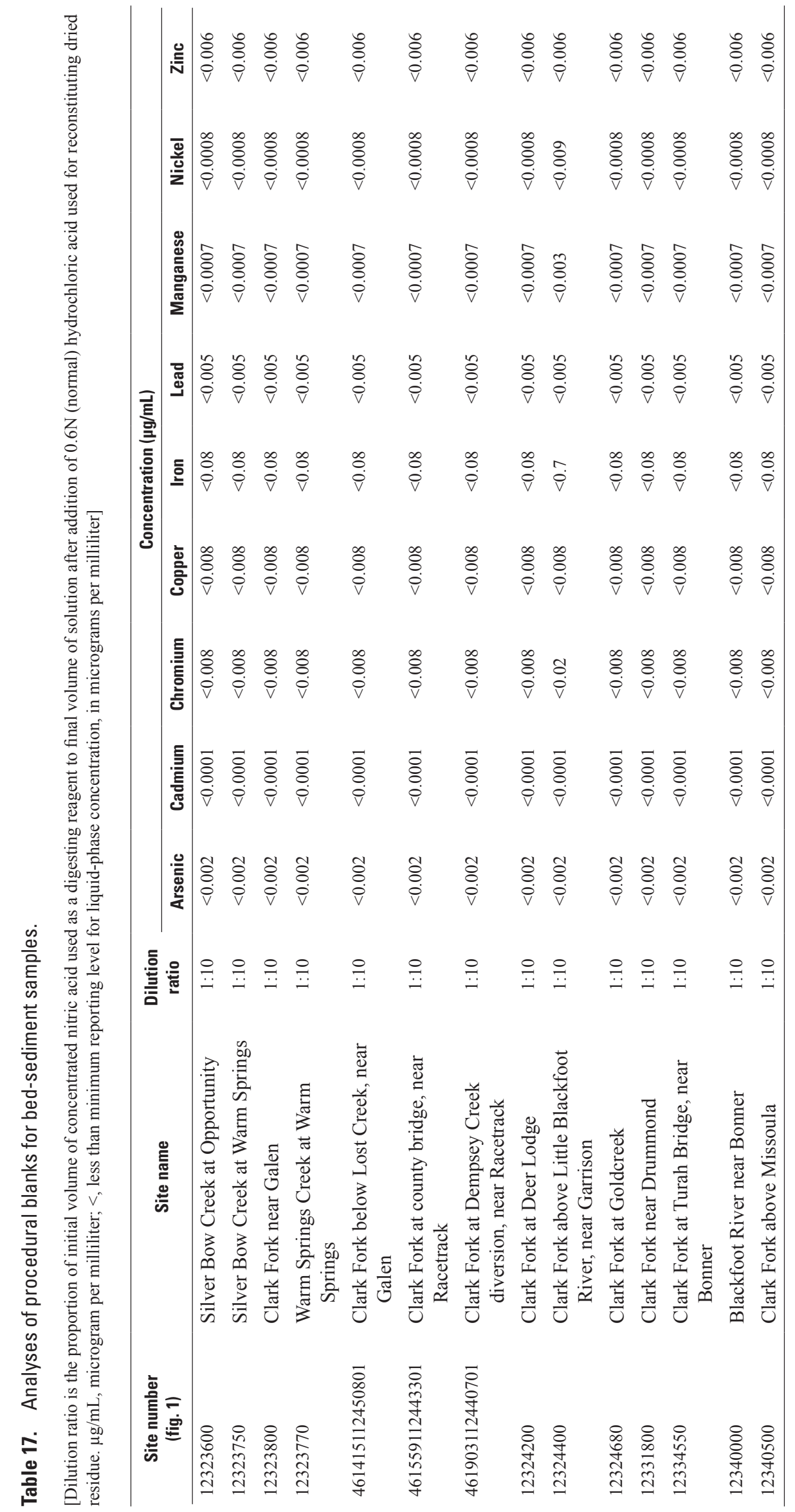


Table 18. Biological data for the Clark Fork Basin, Montana, August 2017.

[Analyses are for the whole-body tissue of aquatic insects. Composite samples were made by combining similar-sized insects of the same species into a sample of sufficient mass for analysis. Concentrations for biota samples composed of two or more composite samples are the means of all analyses. All tissues were analyzed undiluted (dilution ratio $1: 1) . \mu \mathrm{g} / \mathrm{g}$, microgram per gram of dry sample weight]

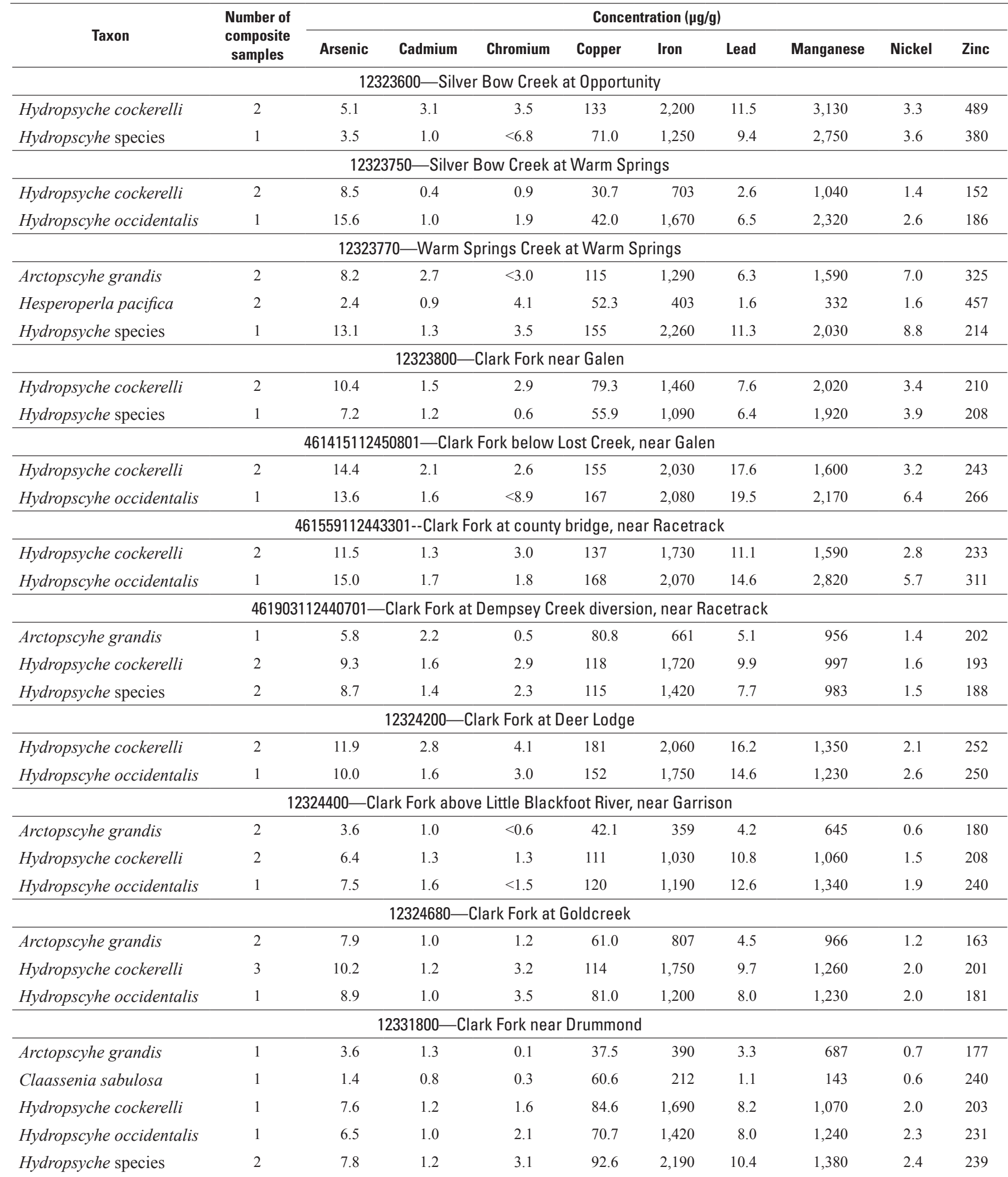


Table 18. Biological data for the Clark Fork Basin, Montana, August 2017.-Continued

[Analyses are for the whole-body tissue of aquatic insects. Composite samples were made by combining similar-sized insects of the same species into a sample of sufficient mass for analysis. Concentrations for biota samples composed of two or more composite samples are the means of all analyses. All tissues were analyzed undiluted (dilution ratio $1: 1) . \mu \mathrm{g} / \mathrm{g}$, microgram per gram of dry sample weight]

\begin{tabular}{|c|c|c|c|c|c|c|c|c|c|c|}
\hline \multirow{2}{*}{ Taxon } & \multirow{2}{*}{$\begin{array}{c}\text { Number of } \\
\text { composite } \\
\text { samples }\end{array}$} & \multicolumn{9}{|c|}{ Concentration $(\mu \mathrm{g} / \mathrm{g})$} \\
\hline & & Arsenic & Cadmium & Chromium & Copper & Iron & Lead & Manganese & Nickel & Zinc \\
\hline \multicolumn{11}{|c|}{ 12334550 — Clark Fork at Turah Bridge, near Bonner } \\
\hline Claassenia sabulosa & 1 & 0.8 & 1.3 & $<0.6$ & 42.3 & 106 & 0.5 & 96.7 & 0.4 & 228 \\
\hline Hydropsyche cockerelli & 2 & 5.6 & 1.5 & 3.5 & 64.9 & 1,840 & 7.5 & 715 & 2.1 & 219 \\
\hline \multicolumn{11}{|c|}{12340000 -Blackfoot River near Bonner } \\
\hline Arctopscyhe grandis & 1 & 3.3 & 0.3 & 2.0 & 16.9 & 1,240 & 1.4 & 522 & 2.2 & 153 \\
\hline Hydropsyche cockerelli & 1 & 3.8 & 0.2 & 5.4 & 16.2 & 2,400 & 2.6 & 572 & 2.6 & 148 \\
\hline Hydropsyche species & 1 & 3.1 & 0.2 & 4.4 & 19.9 & 2,100 & 2.0 & 623 & 2.4 & 160 \\
\hline \multicolumn{11}{|c|}{ 12340500_Clark Fork above Missoula } \\
\hline Hydropsyche cockerelli & 2 & 4.5 & 1.1 & 3.7 & 42.9 & 1,770 & 5.5 & 1,010 & 2.3 & 216 \\
\hline Hydropsyche species & 1 & 3.3 & 1.0 & $<3.4$ & 45.4 & 1,140 & 4.6 & 1,180 & 2.8 & 223 \\
\hline
\end{tabular}

Table 19. Recovery efficiency for analyses of certified reference material for biota samples.

[ $\mu \mathrm{g} / \mathrm{g}$, microgram per gram of dry sample weight; CRM, certified reference material (lobster hepatopancreas)]

\begin{tabular}{lcccc}
\hline Constituent & $\begin{array}{c}\text { Number of } \\
\text { analyses }\end{array}$ & $\begin{array}{c}\text { Certified } \\
\text { concentration } \\
(\boldsymbol{\mu g} / \mathbf{g})\end{array}$ & $\begin{array}{c}\text { Mean CRM } \\
\text { recovery } \\
\text { (percent) }\end{array}$ & $\begin{array}{c}\text { 95-percent confidence } \\
\text { interval for CRM recovery } \\
\text { (percent) }\end{array}$ \\
\hline Arsenic & 12 & \multicolumn{2}{c}{ CRM sample TORT-3 } & \\
Cadmium & 12 & 59.5 & 108 & $107-108$ \\
Chromium & 12 & 42.3 & 86.4 & $89.2-84.0$ \\
Copper & 12 & 1.95 & 86.6 & $84.0-89.2$ \\
Iron & 12 & 497 & 91.9 & $91.4-92.4$ \\
Lead & 12 & 0.225 & 92.4 & $92.1-92.8$ \\
Manganese & 12 & 15.6 & 185 & $182-187$ \\
Nickel & 12 & 5.3 & 92.2 & $91.4-93.0$ \\
Zinc & 12 & 136 & 80.4 & $79.9-80.9$ \\
\hline
\end{tabular}




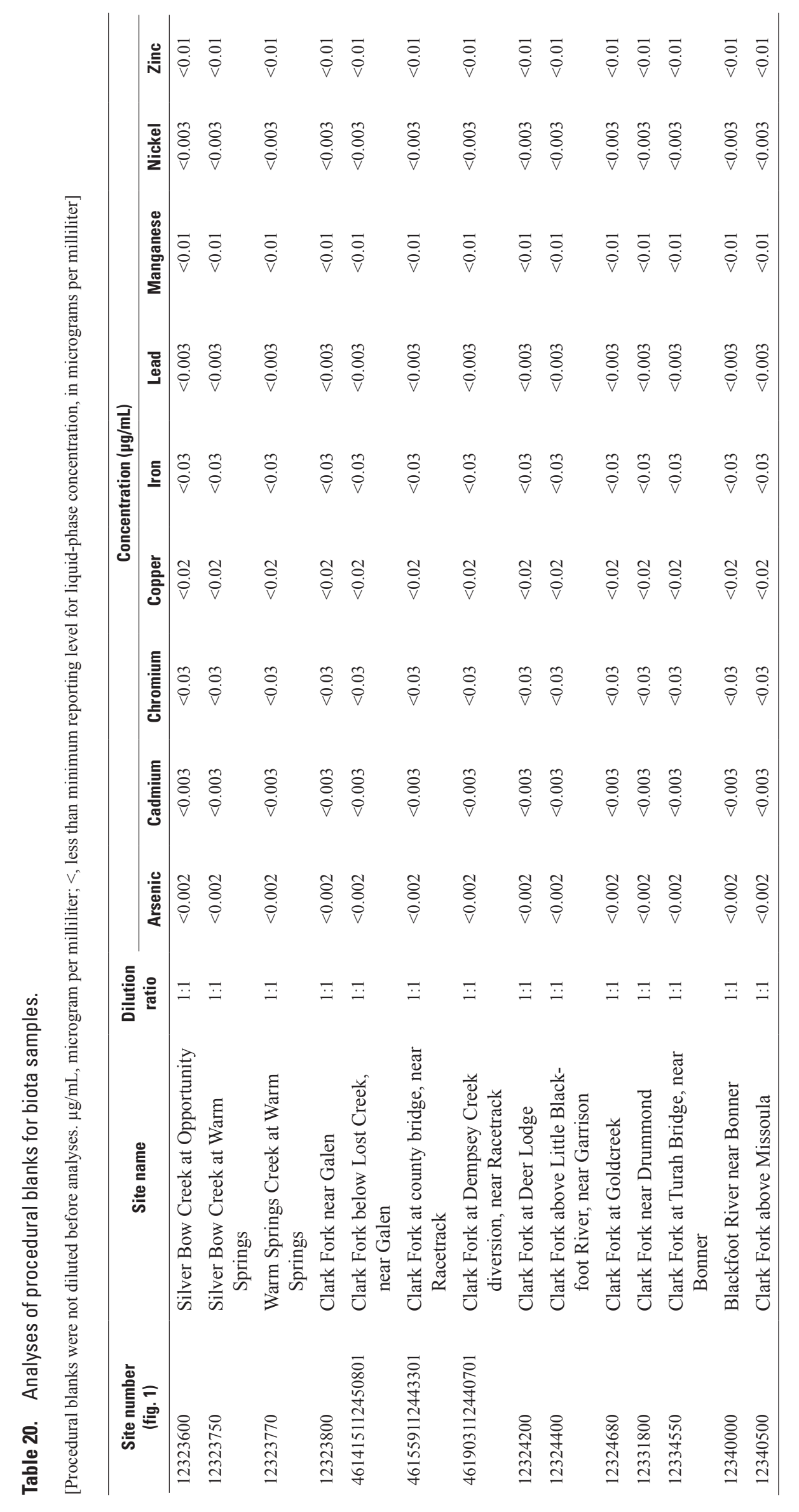


Table 21. Statistical summary of long-term water-quality data for the Clark Fork Basin, Montana, March 1985 through September 2017.

$\left[\mathrm{ft}^{3} / \mathrm{s}\right.$, cubic foot per second; $\mu \mathrm{S} / \mathrm{cm}$, microsiemens per centimeter at 25 degrees Celsius; ${ }^{\circ} \mathrm{C}$, degrees Celsius; lab, laboratory; NTRU, nephelometric turbidity ratio unit; $<$, less than laboratory reporting level ${ }^{1} ; \mathrm{mg} / \mathrm{L}$, milligram per liter; $\mathrm{CaCO}_{3}$, calcium carbonate; $\mu \mathrm{g} / \mathrm{L}$, microgram per liter; $\mathrm{mm}$, millimeter; ton/d, ton per day; --, no data]

\begin{tabular}{|c|c|c|c|c|c|}
\hline Property or constituent and reporting unit & Number of samples & Maximum & Minimum & Mean & Median \\
\hline \multicolumn{6}{|c|}{ 12323230—Blacktail Creek at Harrison Avenue, at Butte } \\
\hline \multicolumn{6}{|c|}{ Period of record for water-quality data: March 1993-August 1995, December 1996-August 2003, December 2004-September 2017} \\
\hline Streamflow, instantaneous $\left(\mathrm{ft}^{3} / \mathrm{s}\right)$ & 187 & 156 & 1.9 & 16 & 9.7 \\
\hline pH, onsite (standard units) & 187 & 8.4 & 7.3 & 7.7 & 7.7 \\
\hline Specific conductance, onsite $(\mu \mathrm{S} / \mathrm{cm})$ & 187 & 412 & 116 & 261 & 261 \\
\hline Temperature, water $\left({ }^{\circ} \mathrm{C}\right)$ & 187 & 18 & 1.0 & 7.9 & 8.0 \\
\hline Turbidity, unfiltered, lab (NTRU) & 31 & 25 & $<2.0$ & ${ }^{14} 4.5$ & 3.5 \\
\hline Hardness, filtered $\left(\mathrm{mg} / \mathrm{L}\right.$ as $\left.\mathrm{CaCO}_{3}\right)$ & 187 & 153 & 37.7 & 104 & 104 \\
\hline Calcium, filtered (mg/L) & 187 & 42.9 & 10.6 & 29.6 & 29.7 \\
\hline Magnesium, filtered (mg/L) & 187 & 11.1 & 2.71 & 7.21 & 7.16 \\
\hline Potassium, filtered (mg/L) & 49 & 6.4 & 2 & 2.75 & 2.57 \\
\hline Sodium, filtered $(\mathrm{mg} / \mathrm{L})$ & 49 & 18 & 6.4 & 10.6 & 10.2 \\
\hline Alkalinity, filtered, lab (mg/L) & 21 & 124 & 54.5 & 85.5 & 78.4 \\
\hline Chloride, filtered (mg/L) & 49 & 18 & 2.8 & 8.5 & 8 \\
\hline Fluoride, filtered (mg/L) & 49 & 0.6 & 0.18 & 0.28 & 0.3 \\
\hline Silica, filtered (mg/L) & 49 & 32 & 14 & 24.3 & 24.4 \\
\hline Sulfate, filtered (mg/L) & 49 & 40.2 & 14.7 & 26.2 & 26 \\
\hline Nitrate plus nitrite, filtered $(\mathrm{mg} / \mathrm{L})$ & 31 & 1.24 & 0.15 & 0.6 & 0.5 \\
\hline Cadmium, filtered $(\mu \mathrm{g} / \mathrm{L})$ & 185 & 0.5 & $<0.03$ & ${ }^{1} 0.04$ & 0.02 \\
\hline Cadmium, unfiltered recoverable $(\mu \mathrm{g} / \mathrm{L})$ & 187 & 0.12 & $<0.02$ & ${ }^{1} 0.04$ & $<1.00$ \\
\hline Copper, filtered $(\mu \mathrm{g} / \mathrm{L})$ & 186 & 10 & 0.8 & 3.5 & 3 \\
\hline Copper, unfiltered recoverable $(\mu \mathrm{g} / \mathrm{L})$ & 187 & 52 & 0.91 & 6.22 & 4.9 \\
\hline Iron, filtered $(\mu \mathrm{g} / \mathrm{L})$ & 187 & 739 & 15.2 & 198 & 180 \\
\hline Iron, unfiltered recoverable $(\mu \mathrm{g} / \mathrm{L})$ & 187 & 4,220 & 123 & 660 & 592 \\
\hline Lead, filtered $(\mu \mathrm{g} / \mathrm{L})$ & 187 & 2.8 & $<0.03$ & ${ }^{1} 0.18$ & 0.08 \\
\hline Lead, unfiltered recoverable $(\mu \mathrm{g} / \mathrm{L})$ & 187 & 47 & $<1.00$ & ${ }^{1} 1.51$ & 0.64 \\
\hline Manganese, filtered $(\mu \mathrm{g} / \mathrm{L})$ & 187 & 144 & 14.2 & 43.6 & 38.6 \\
\hline Manganese, unfiltered recoverable $(\mu \mathrm{g} / \mathrm{L})$ & 187 & 240 & 23.5 & 60.4 & 52.7 \\
\hline Zinc, filtered $(\mu \mathrm{g} / \mathrm{L})$ & 185 & 11 & $<1.00$ & ${ }^{1} 3.14$ & 2.4 \\
\hline Zinc, unfiltered recoverable $(\mu \mathrm{g} / \mathrm{L})$ & 187 & 130 & $<3.00$ & 17.42 & 4 \\
\hline Arsenic, filtered $(\mu \mathrm{g} / \mathrm{L})$ & 186 & 13 & 1 & 4 & 3 \\
\hline Arsenic, unfiltered recoverable $(\mu \mathrm{g} / \mathrm{L})$ & 187 & 18 & 1 & 5 & 5 \\
\hline Organic carbon, filtered (mg/L) & 21 & 9.52 & 1.4 & 4.7 & 4.3 \\
\hline Sediment, suspended (percent finer than $0.062 \mathrm{~mm}$ ) & 187 & 97 & 50 & 83 & 85 \\
\hline Sediment, suspended concentration $(\mathrm{mg} / \mathrm{L})$ & 187 & 139 & 1 & 11 & 7 \\
\hline Sediment, suspended discharge (ton/d) & 187 & 59 & 0.01 & 0.88 & 0.17 \\
\hline
\end{tabular}


Table 21. Statistical summary of long-term water-quality data for the Clark Fork Basin, Montana, March 1985 through September 2017.-Continued

$\left[\mathrm{ft}^{3} / \mathrm{s}\right.$, cubic foot per second; $\mu \mathrm{S} / \mathrm{cm}$, microsiemens per centimeter at 25 degrees Celsius; ${ }^{\circ} \mathrm{C}$, degrees Celsius; lab, laboratory; NTRU, nephelometric turbidity ratio unit; <, less than laboratory reporting level ${ }^{1} ; \mathrm{mg} / \mathrm{L}$, milligram per liter; $\mathrm{CaCO}_{3}$, calcium carbonate; $\mu \mathrm{g} / \mathrm{L}$, microgram per liter; $\mathrm{mm}$, millimeter; ton/d, ton per day; --, no data]

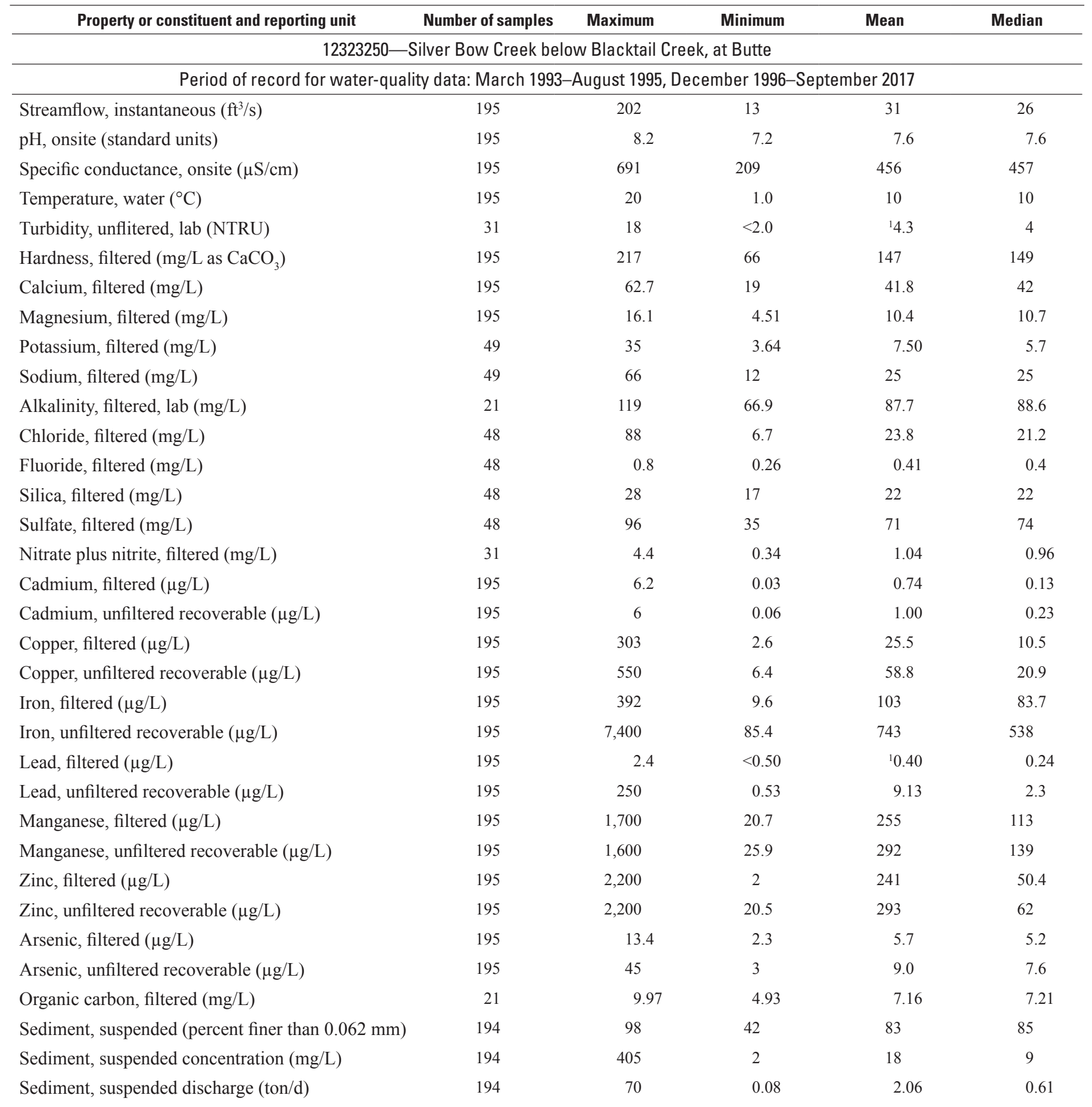


Table 21. Statistical summary of long-term water-quality data for the Clark Fork Basin, Montana, March 1985 through September 2017.-Continued

$\left[\mathrm{ft} / \mathrm{s}\right.$, cubic foot per second; $\mu \mathrm{S} / \mathrm{cm}$, microsiemens per centimeter at 25 degrees Celsius; ${ }^{\circ} \mathrm{C}$, degrees Celsius; lab, laboratory; NTRU, nephelometric turbidity ratio unit; <, less than laboratory reporting level ${ }^{1} ; \mathrm{mg} / \mathrm{L}$, milligram per liter; $\mathrm{CaCO}_{3}$, calcium carbonate; $\mu \mathrm{g} / \mathrm{L}$, microgram per liter; $\mathrm{mm}$, millimeter; ton/d, ton per day; --, no data]

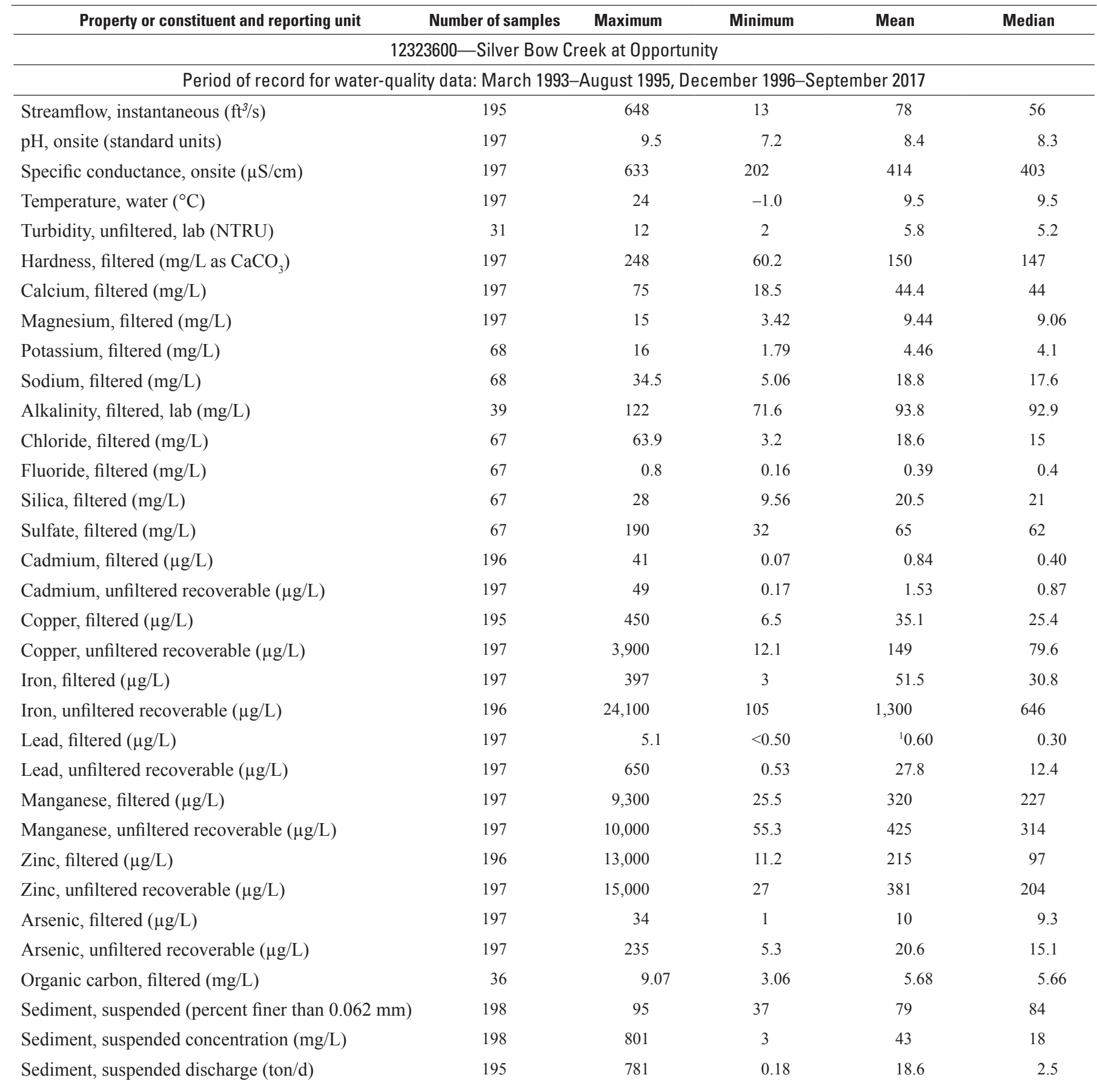


Table 21. Statistical summary of long-term water-quality data for the Clark Fork Basin, Montana, March 1985 through September 2017.-Continued

$\left[\mathrm{ft}^{3} / \mathrm{s}\right.$, cubic foot per second; $\mu \mathrm{S} / \mathrm{cm}$, microsiemens per centimeter at 25 degrees Celsius; ${ }^{\circ} \mathrm{C}$, degrees Celsius; lab, laboratory; NTRU, nephelometric turbidity ratio unit; <, less than laboratory reporting level ${ }^{1} ; \mathrm{mg} / \mathrm{L}$, milligram per liter; $\mathrm{CaCO}_{3}$, calcium carbonate; $\mu \mathrm{g} / \mathrm{L}$, microgram per liter; $\mathrm{mm}$, millimeter; ton/d, ton per day; --, no data]

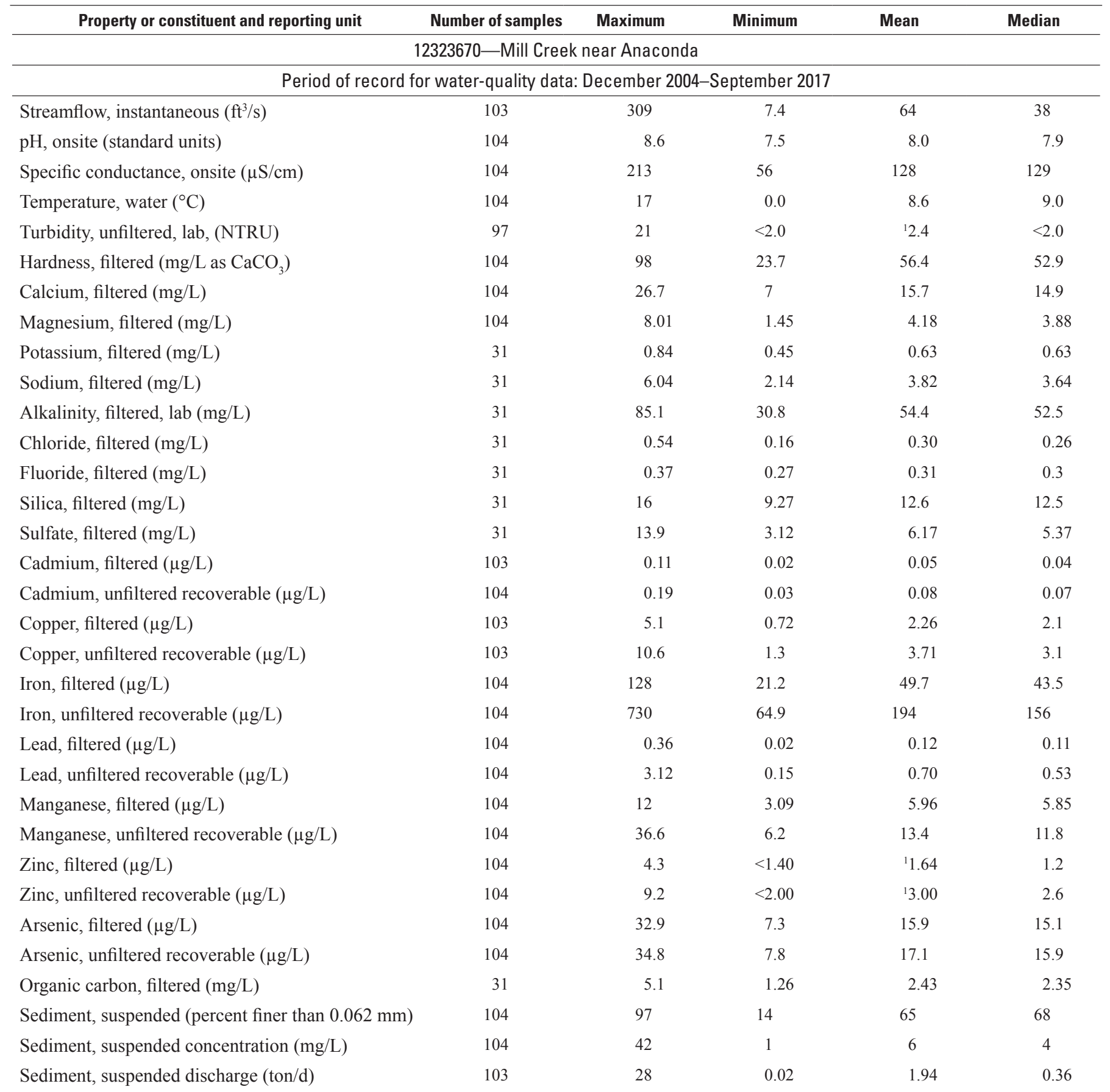


Table 21. Statistical summary of long-term water-quality data for the Clark Fork Basin, Montana, March 1985 through September 2017.-Continued

$\left[\mathrm{ft} / \mathrm{s}\right.$, cubic foot per second; $\mu \mathrm{S} / \mathrm{cm}$, microsiemens per centimeter at 25 degrees Celsius; ${ }^{\circ} \mathrm{C}$, degrees Celsius; lab, laboratory; NTRU, nephelometric turbidity ratio unit; <, less than laboratory reporting level ${ }^{1} ; \mathrm{mg} / \mathrm{L}$, milligram per liter; $\mathrm{CaCO}_{3}$, calcium carbonate; $\mu \mathrm{g} / \mathrm{L}$, microgram per liter; $\mathrm{mm}$, millimeter; ton/d, ton per day; --, no data]

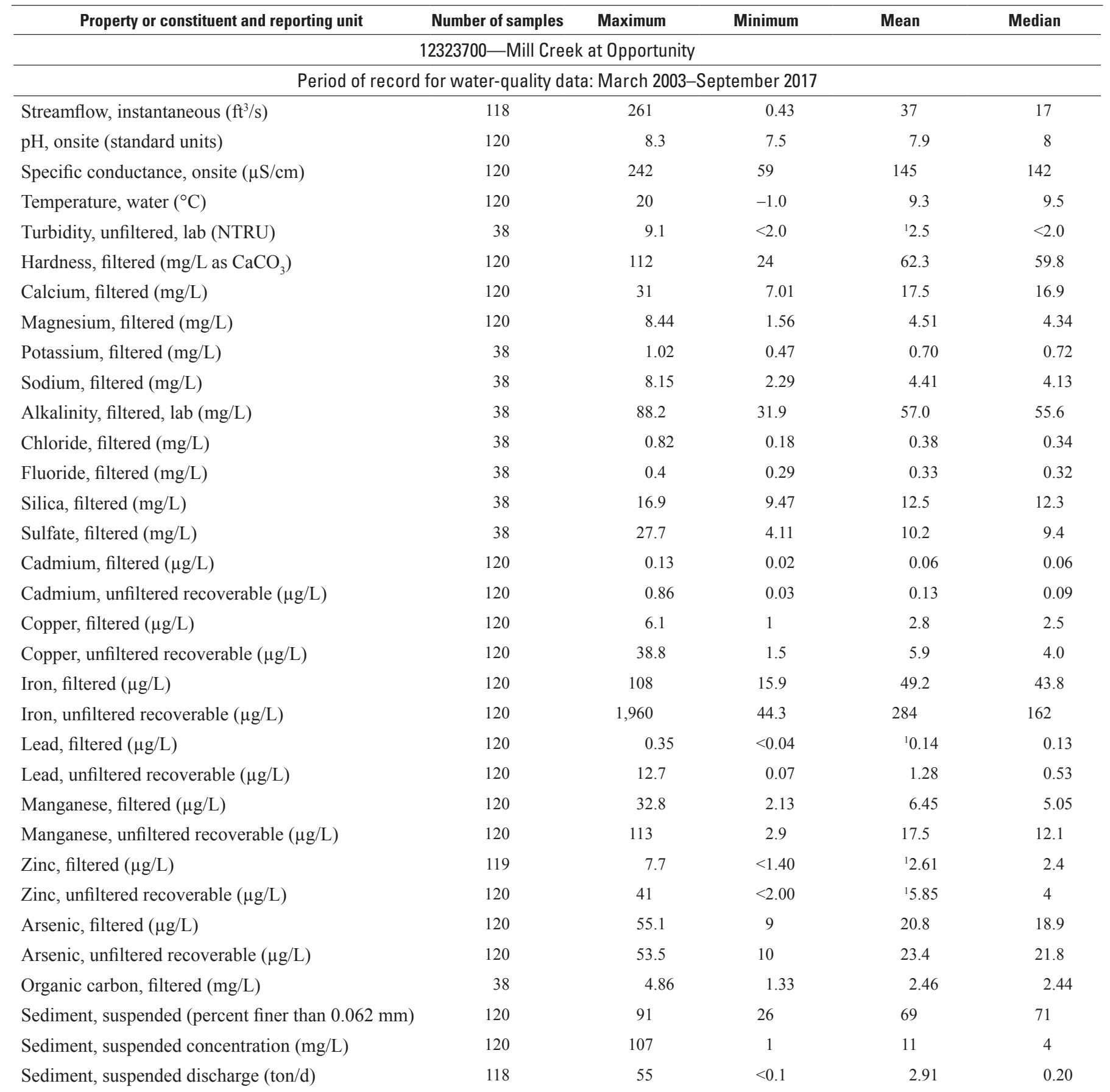


Table 21. Statistical summary of long-term water-quality data for the Clark Fork Basin, Montana, March 1985 through September 2017.-Continued

$\left[\mathrm{ft}^{3} / \mathrm{s}\right.$, cubic foot per second; $\mu \mathrm{S} / \mathrm{cm}$, microsiemens per centimeter at 25 degrees Celsius; ${ }^{\circ} \mathrm{C}$, degrees Celsius; lab, laboratory; NTRU, nephelometric turbidity ratio unit; <, less than laboratory reporting level ${ }^{1} ; \mathrm{mg} / \mathrm{L}$, milligram per liter; $\mathrm{CaCO}_{3}$, calcium carbonate; $\mu \mathrm{g} / \mathrm{L}$, microgram per liter; $\mathrm{mm}$, millimeter; ton/d, ton per day; --, no data]

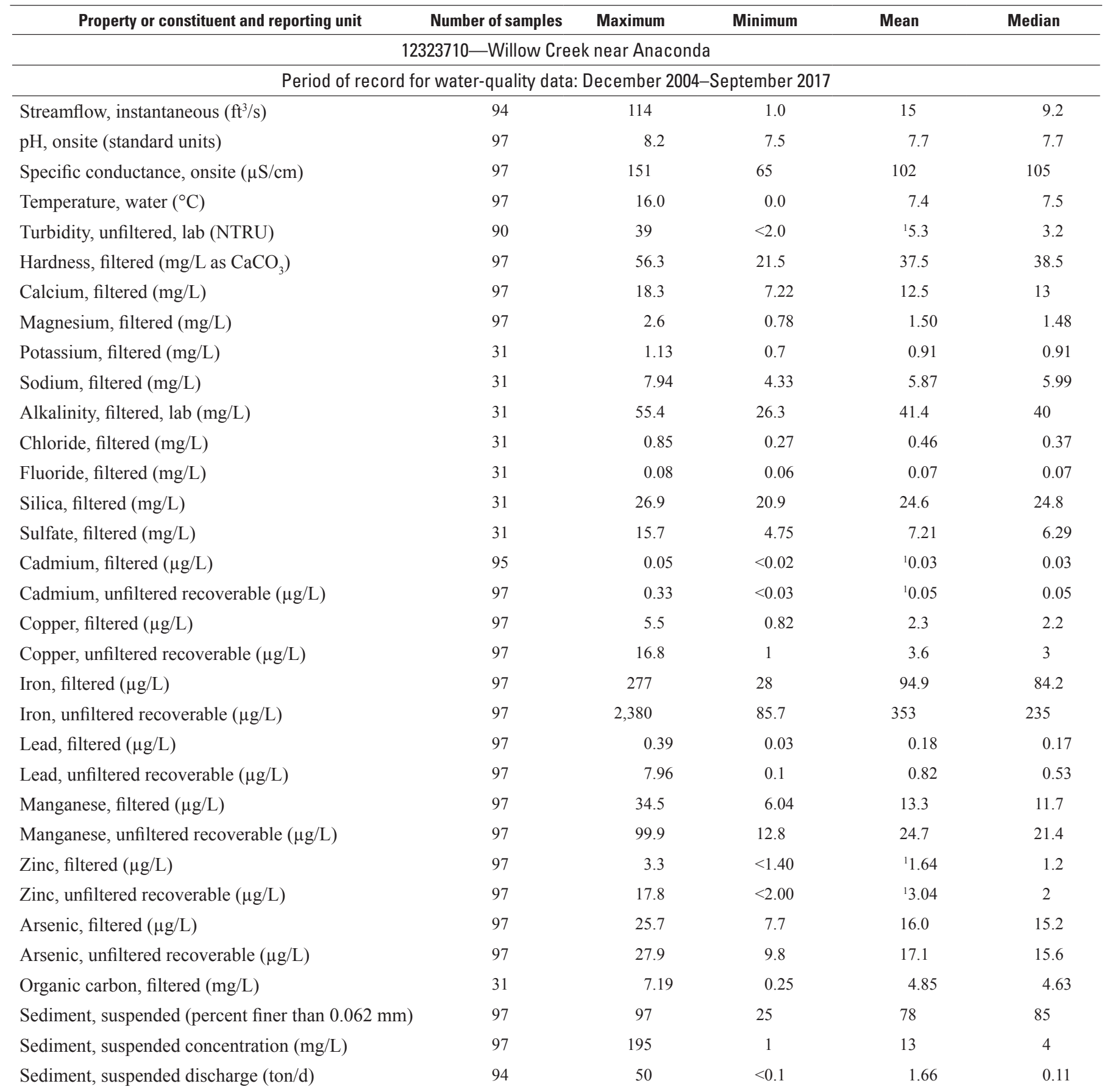


Table 21. Statistical summary of long-term water-quality data for the Clark Fork Basin, Montana, March 1985 through September 2017.-Continued

$\left[\mathrm{ft} / \mathrm{s}\right.$, cubic foot per second; $\mu \mathrm{S} / \mathrm{cm}$, microsiemens per centimeter at 25 degrees Celsius; ${ }^{\circ} \mathrm{C}$, degrees Celsius; lab, laboratory; NTRU, nephelometric turbidity ratio unit; $<$, less than laboratory reporting level ${ }^{1} ; \mathrm{mg} / \mathrm{L}$, milligram per liter; $\mathrm{CaCO}_{3}$, calcium carbonate; $\mu \mathrm{g} / \mathrm{L}$, microgram per liter; $\mathrm{mm}$, millimeter; ton/d, ton per day; --, no data]

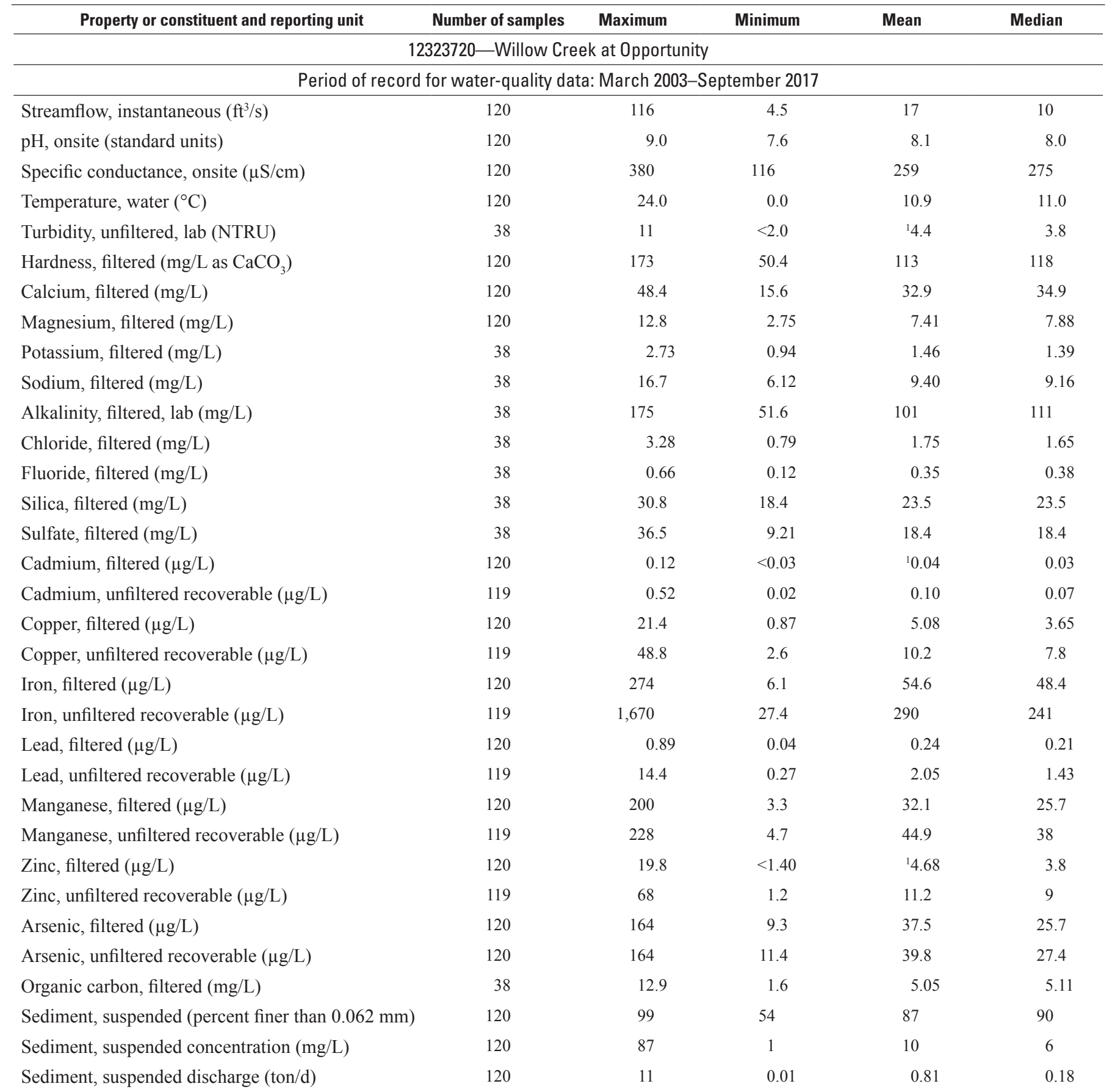


Table 21. Statistical summary of long-term water-quality data for the Clark Fork Basin, Montana, March 1985 through September 2017.-Continued

$\left[\mathrm{ft}^{3} / \mathrm{s}\right.$, cubic foot per second; $\mu \mathrm{S} / \mathrm{cm}$, microsiemens per centimeter at 25 degrees Celsius; ${ }^{\circ} \mathrm{C}$, degrees Celsius; lab, laboratory; NTRU, nephelometric turbidity ratio unit; $<$, less than laboratory reporting level ${ }^{1} ; \mathrm{mg} / \mathrm{L}$, milligram per liter; $\mathrm{CaCO}_{3}$, calcium carbonate; $\mu \mathrm{g} / \mathrm{L}$, microgram per liter; $\mathrm{mm}$, millimeter; ton/d, ton per day; --, no data]

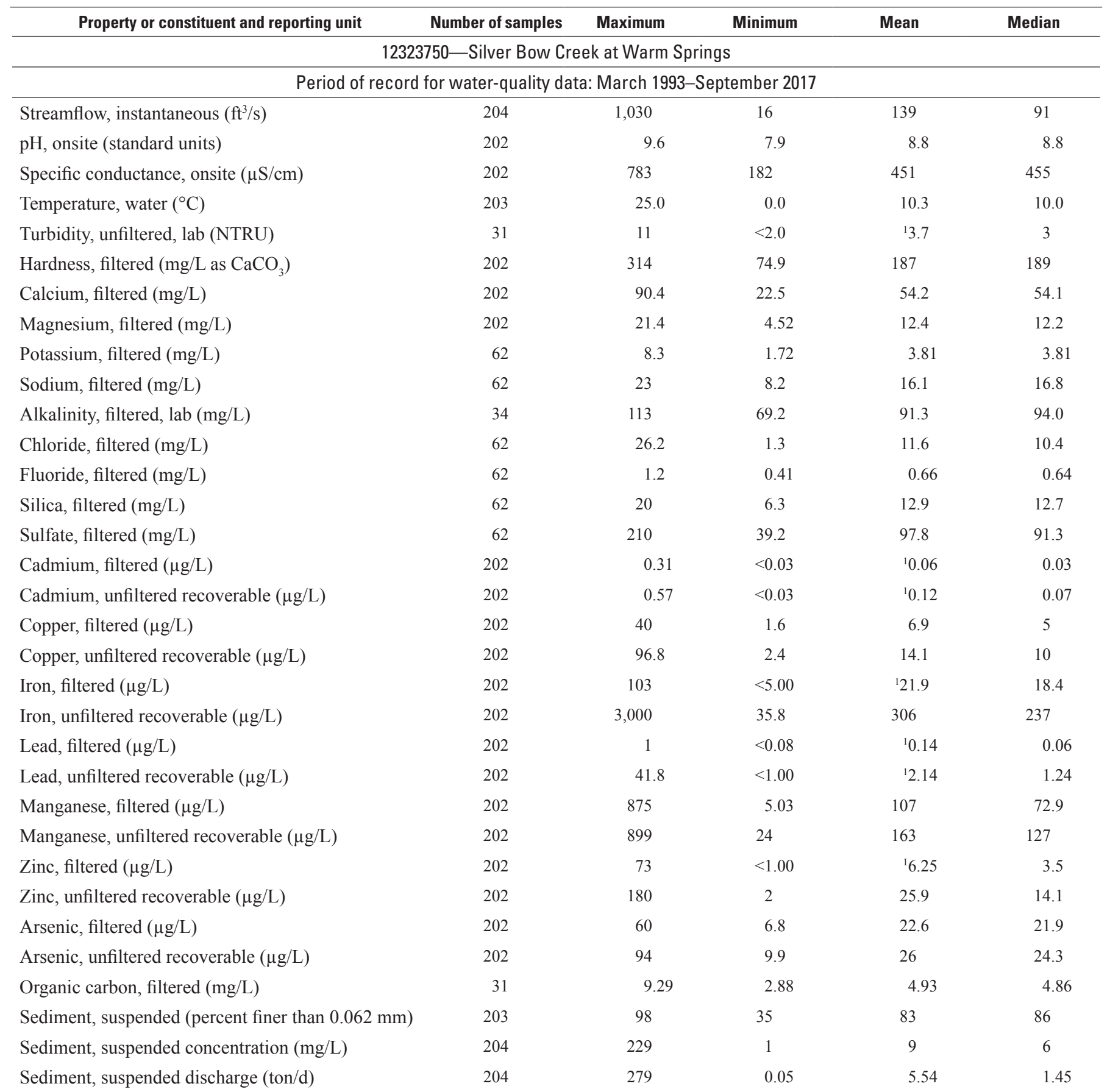


Table 21. Statistical summary of long-term water-quality data for the Clark Fork Basin, Montana, March 1985 through September 2017.-Continued

$\left[\mathrm{ft} / \mathrm{s}\right.$, cubic foot per second; $\mu \mathrm{S} / \mathrm{cm}$, microsiemens per centimeter at 25 degrees Celsius; ${ }^{\circ} \mathrm{C}$, degrees Celsius; lab, laboratory; NTRU, nephelometric turbidity ratio unit; <, less than laboratory reporting level ${ }^{1} ; \mathrm{mg} / \mathrm{L}$, milligram per liter; $\mathrm{CaCO}_{3}$, calcium carbonate; $\mu \mathrm{g} / \mathrm{L}$, microgram per liter; $\mathrm{mm}$, millimeter; ton/d, ton per day; --, no data]

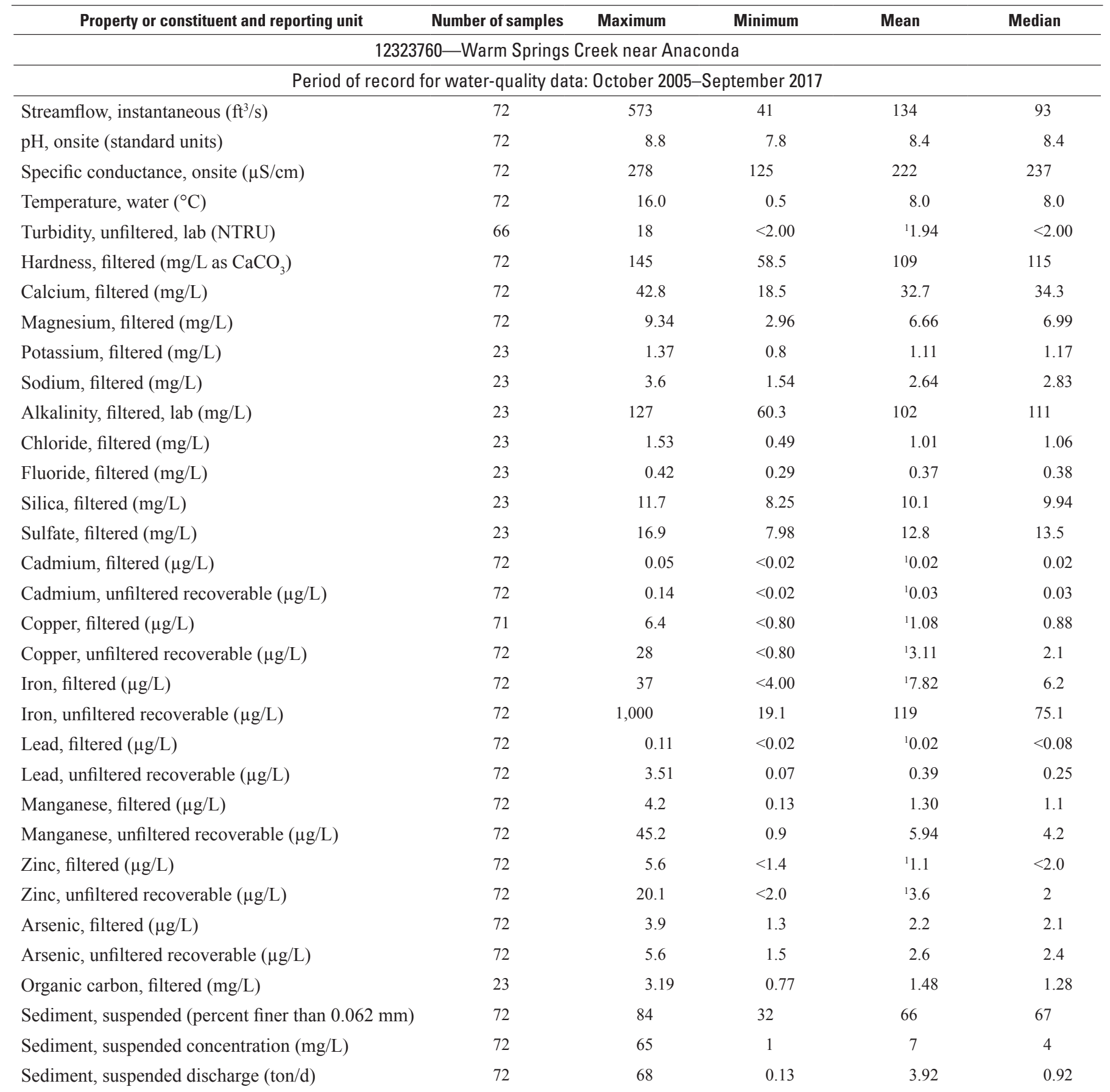


Table 21. Statistical summary of long-term water-quality data for the Clark Fork Basin, Montana, March 1985 through September 2017.-Continued

$\left[\mathrm{ft}^{3} / \mathrm{s}\right.$, cubic foot per second; $\mu \mathrm{S} / \mathrm{cm}$, microsiemens per centimeter at 25 degrees Celsius; ${ }^{\circ} \mathrm{C}$, degrees Celsius; lab, laboratory; NTRU, nephelometric turbidity ratio unit; $<$, less than laboratory reporting level ${ }^{1} ; \mathrm{mg} / \mathrm{L}$, milligram per liter; $\mathrm{CaCO}_{3}$, calcium carbonate; $\mu \mathrm{g} / \mathrm{L}$, microgram per liter; $\mathrm{mm}$, millimeter; ton/d, ton per day; --, no data]

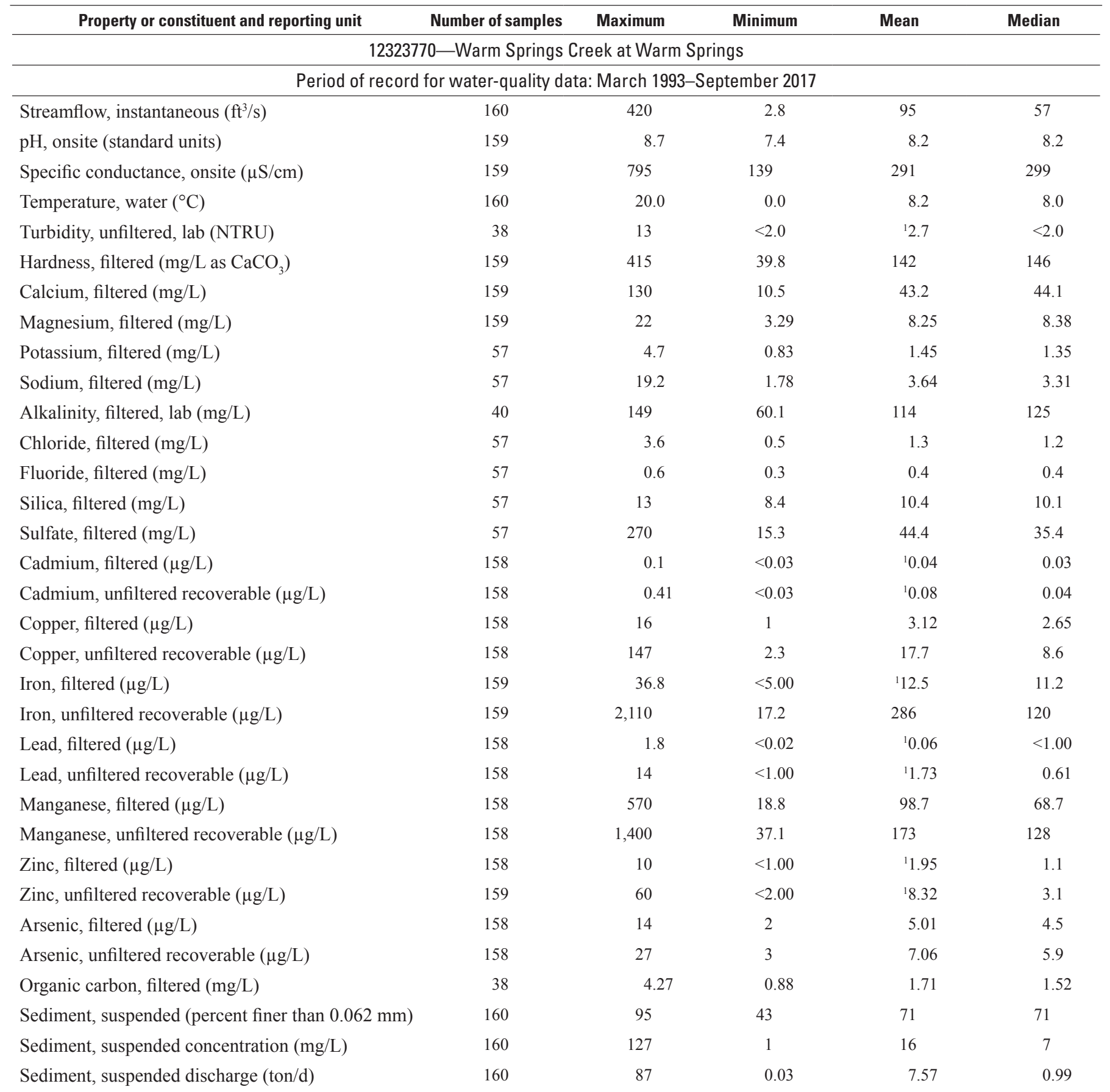




\section{Water-Quality, Bed-Sediment, and Biological Data and Statistical Summaries of Data, Clark Fork Basin, Montana}

Table 21. Statistical summary of long-term water-quality data for the Clark Fork Basin, Montana, March 1985 through September 2017.-Continued

$\left[\mathrm{ft} / \mathrm{s}\right.$, cubic foot per second; $\mu \mathrm{S} / \mathrm{cm}$, microsiemens per centimeter at 25 degrees Celsius; ${ }^{\circ} \mathrm{C}$, degrees Celsius; lab, laboratory; NTRU, nephelometric turbidity ratio unit; <, less than laboratory reporting level ${ }^{1} ; \mathrm{mg} / \mathrm{L}$, milligram per liter; $\mathrm{CaCO}_{3}$, calcium carbonate; $\mu \mathrm{g} / \mathrm{L}$, microgram per liter; mm, millimeter; ton/d, ton per day; --, no data]

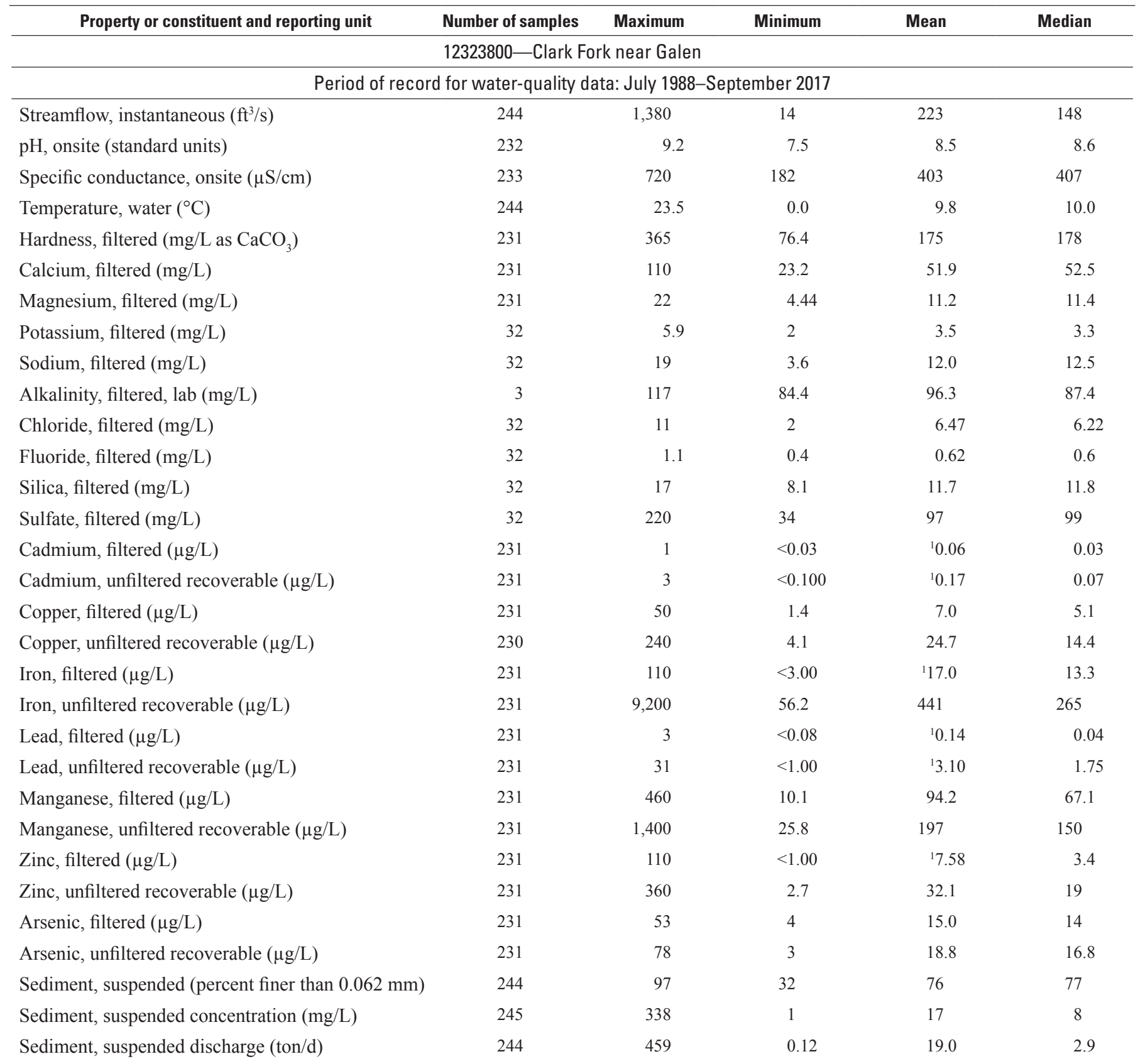


Table 21. Statistical summary of long-term water-quality data for the Clark Fork Basin, Montana, March 1985 through September 2017.-Continued

$\left[\mathrm{ft}^{3} / \mathrm{s}\right.$, cubic foot per second; $\mu \mathrm{S} / \mathrm{cm}$, microsiemens per centimeter at 25 degrees Celsius; ${ }^{\circ} \mathrm{C}$, degrees Celsius; lab, laboratory; NTRU, nephelometric turbidity ratio unit; <, less than laboratory reporting level ${ }^{1} ; \mathrm{mg} / \mathrm{L}$, milligram per liter; $\mathrm{CaCO}_{3}$, calcium carbonate; $\mu \mathrm{g} / \mathrm{L}$, microgram per liter; $\mathrm{mm}$, millimeter; ton/d, ton per day; --, no data]

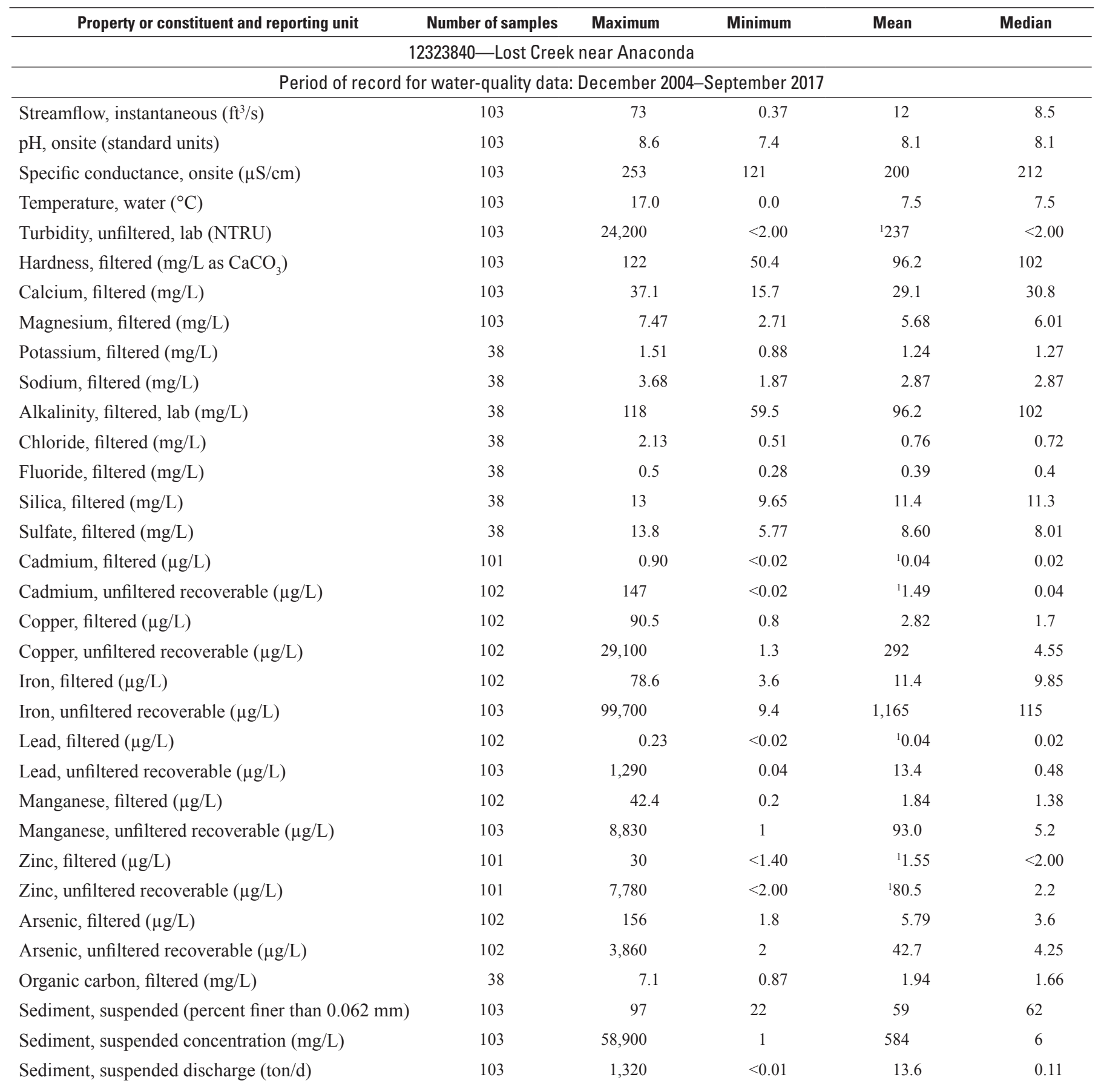


Table 21. Statistical summary of long-term water-quality data for the Clark Fork Basin, Montana, March 1985 through September 2017.-Continued

$\left[\mathrm{ft} / \mathrm{s}\right.$, cubic foot per second; $\mu \mathrm{S} / \mathrm{cm}$, microsiemens per centimeter at 25 degrees Celsius; ${ }^{\circ} \mathrm{C}$, degrees Celsius; lab, laboratory; NTRU, nephelometric turbidity ratio unit; <, less than laboratory reporting level ${ }^{1} ; \mathrm{mg} / \mathrm{L}$, milligram per liter; $\mathrm{CaCO}_{3}$, calcium carbonate; $\mu \mathrm{g} / \mathrm{L}$, microgram per liter; mm, millimeter; ton/d, ton per day; --, no data]

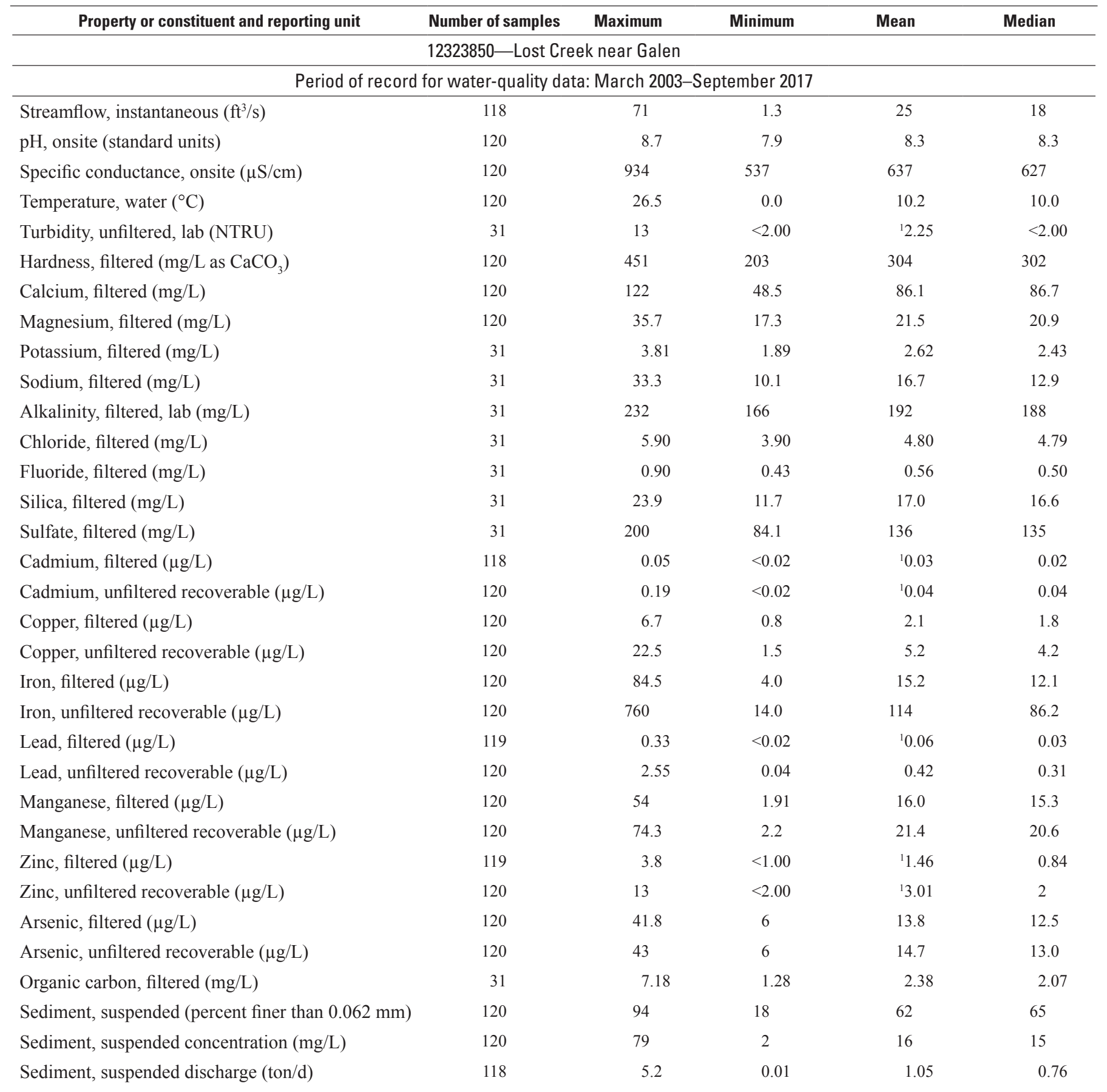


Table 21. Statistical summary of long-term water-quality data for the Clark Fork Basin, Montana, March 1985 through September 2017.-Continued

$\left[\mathrm{ft}^{3} / \mathrm{s}\right.$, cubic foot per second; $\mu \mathrm{S} / \mathrm{cm}$, microsiemens per centimeter at 25 degrees Celsius; ${ }^{\circ} \mathrm{C}$, degrees Celsius; lab, laboratory; NTRU, nephelometric turbidity ratio unit; $<$, less than laboratory reporting level ${ }^{1} ; \mathrm{mg} / \mathrm{L}$, milligram per liter; $\mathrm{CaCO}_{3}$, calcium carbonate; $\mu \mathrm{g} / \mathrm{L}$, microgram per liter; $\mathrm{mm}$, millimeter; ton/d, ton per day; --, no data]

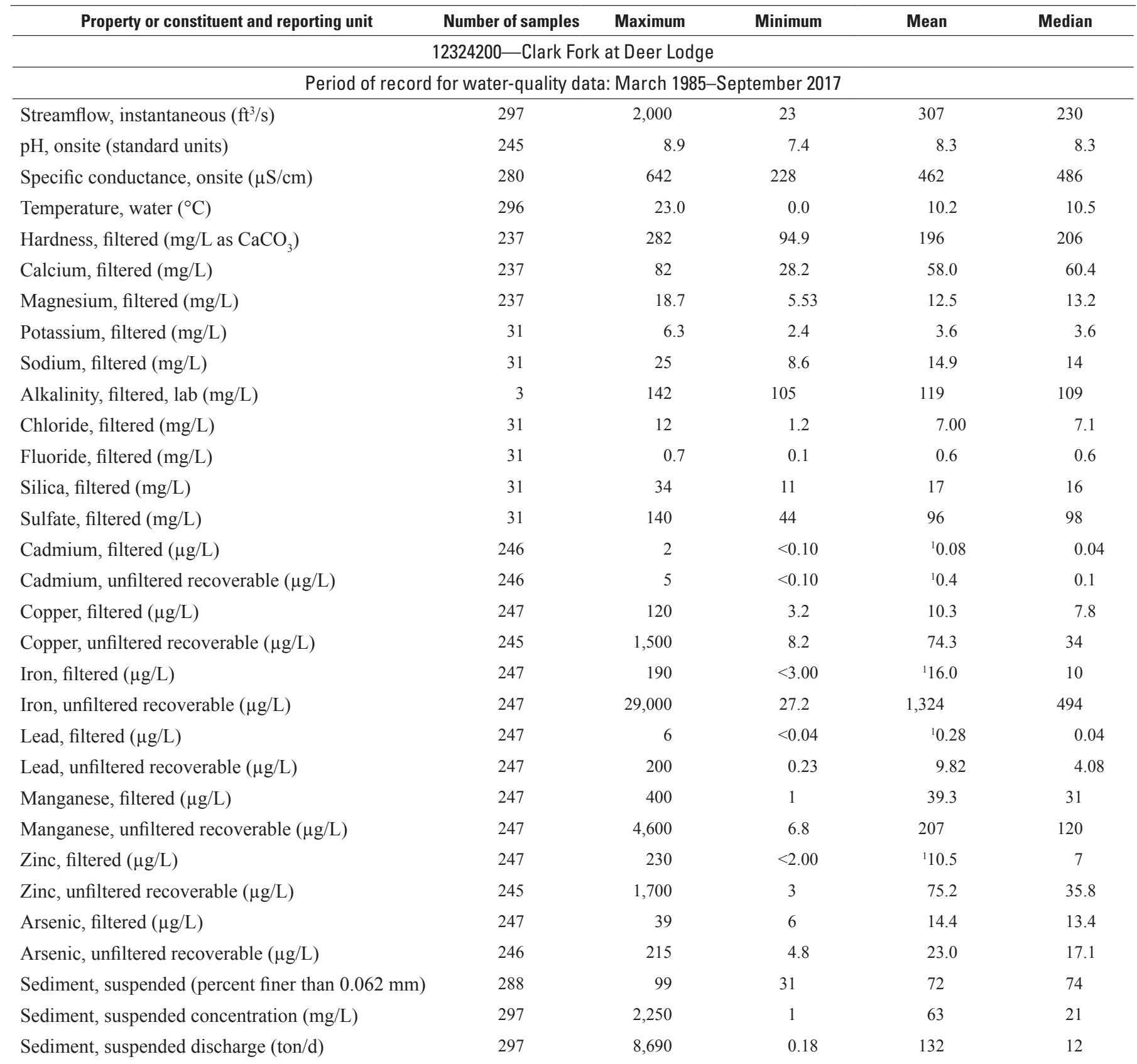


Table 21. Statistical summary of long-term water-quality data for the Clark Fork Basin, Montana, March 1985 through September 2017.-Continued

$\left[\mathrm{ft} / \mathrm{s}\right.$, cubic foot per second; $\mu \mathrm{S} / \mathrm{cm}$, microsiemens per centimeter at 25 degrees Celsius; ${ }^{\circ} \mathrm{C}$, degrees Celsius; lab, laboratory; NTRU, nephelometric turbidity ratio unit; <, less than laboratory reporting level ${ }^{1} ; \mathrm{mg} / \mathrm{L}$, milligram per liter; $\mathrm{CaCO}_{3}$, calcium carbonate; $\mu \mathrm{g} / \mathrm{L}$, microgram per liter; mm, millimeter; ton/d, ton per day; --, no data]

\begin{tabular}{|c|c|c|c|c|c|}
\hline Property or constituent and reporting unit & Number of samples & Maximum & Minimum & Mean & Median \\
\hline \multicolumn{6}{|c|}{12324400 - Clark Fork above Little Blackfoot River, near Garrison } \\
\hline \multicolumn{6}{|c|}{ Period of record for water-quality data: March 2009-September 2017} \\
\hline $\mathrm{pH}$, onsite (standard units) & 70 & 8.9 & 7.9 & 8.4 & 8.4 \\
\hline Specific conductance, onsite $(\mu \mathrm{S} / \mathrm{cm})$ & 70 & 530 & 249 & 417 & 443 \\
\hline Hardness, filtered $\left(\mathrm{mg} / \mathrm{L}\right.$ as $\left.\mathrm{CaCO}_{3}\right)$ & 70 & 236 & 104 & 184 & 196 \\
\hline Calcium, filtered (mg/L) & 70 & 69.4 & 31.8 & 53.6 & 56.8 \\
\hline Magnesium, filtered (mg/L) & 70 & 15.8 & 5.93 & 12.1 & 13.2 \\
\hline Cadmium, filtered $(\mu \mathrm{g} / \mathrm{L})$ & 70 & 0.23 & 0.02 & 0.07 & 0.07 \\
\hline Cadmium, unfiltered recoverable $(\mu \mathrm{g} / \mathrm{L})$ & 70 & 3.25 & 0.03 & 0.28 & 0.18 \\
\hline Iron, unfiltered recoverable $(\mu \mathrm{g} / \mathrm{L})$ & 70 & 17,300 & 21.5 & 1,043 & 541 \\
\hline Lead, filtered $(\mu \mathrm{g} / \mathrm{L})$ & 70 & 0.96 & 0.04 & 0.17 & 0.13 \\
\hline Lead, unfiltered recoverable $(\mu \mathrm{g} / \mathrm{L})$ & 70 & 132 & 0.15 & 8.71 & 4.08 \\
\hline Manganese, filtered $(\mu \mathrm{g} / \mathrm{L})$ & 70 & 164 & 2.68 & 29.2 & 24.1 \\
\hline Manganese, unfiltered recoverable $(\mu \mathrm{g} / \mathrm{L})$ & 70 & 1,060 & 6.4 & 127 & 101 \\
\hline Zinc, filtered $(\mu \mathrm{g} / \mathrm{L})$ & 70 & 37.1 & $<2.00$ & ${ }^{1} 5.70$ & 4.9 \\
\hline Zinc, unfiltered recoverable $(\mu \mathrm{g} / \mathrm{L})$ & 70 & 800 & 2 & 54.7 & 28.9 \\
\hline Arsenic, filtered $(\mu \mathrm{g} / \mathrm{L})$ & 70 & 36.7 & 7.8 & 15.3 & 15.3 \\
\hline Arsenic, unfiltered recoverable $(\mu \mathrm{g} / \mathrm{L})$ & 70 & 138 & 10.5 & 22.5 & 18.2 \\
\hline
\end{tabular}


Table 21. Statistical summary of long-term water-quality data for the Clark Fork Basin, Montana, March 1985 through September 2017.-Continued

$\left[\mathrm{ft}^{3} / \mathrm{s}\right.$, cubic foot per second; $\mu \mathrm{S} / \mathrm{cm}$, microsiemens per centimeter at 25 degrees Celsius; ${ }^{\circ} \mathrm{C}$, degrees Celsius; lab, laboratory; NTRU, nephelometric turbidity ratio unit; <, less than laboratory reporting level ${ }^{1} ; \mathrm{mg} / \mathrm{L}$, milligram per liter; $\mathrm{CaCO}_{3}$, calcium carbonate; $\mu \mathrm{g} / \mathrm{L}$, microgram per liter; $\mathrm{mm}$, millimeter; ton/d, ton per day; --, no data]

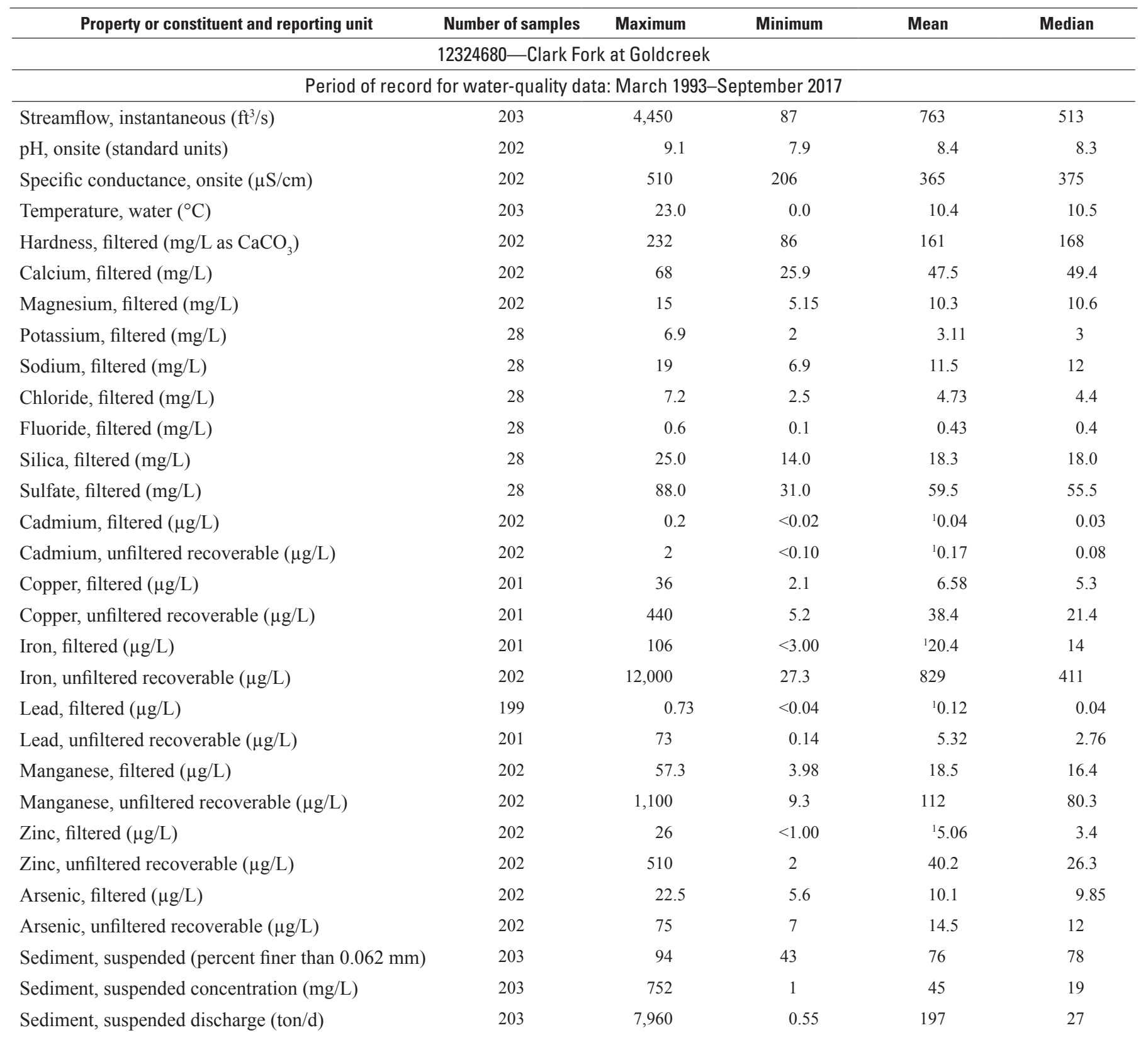


Table 21. Statistical summary of long-term water-quality data for the Clark Fork Basin, Montana, March 1985 through September 2017.-Continued

$\left[\mathrm{ft} / \mathrm{s}\right.$, cubic foot per second; $\mu \mathrm{S} / \mathrm{cm}$, microsiemens per centimeter at 25 degrees Celsius; ${ }^{\circ} \mathrm{C}$, degrees Celsius; lab, laboratory; NTRU, nephelometric turbidity ratio unit; <, less than laboratory reporting level ${ }^{1} ; \mathrm{mg} / \mathrm{L}$, milligram per liter; $\mathrm{CaCO}_{3}$, calcium carbonate; $\mu \mathrm{g} / \mathrm{L}$, microgram per liter; mm, millimeter; ton/d, ton per day; --, no data]

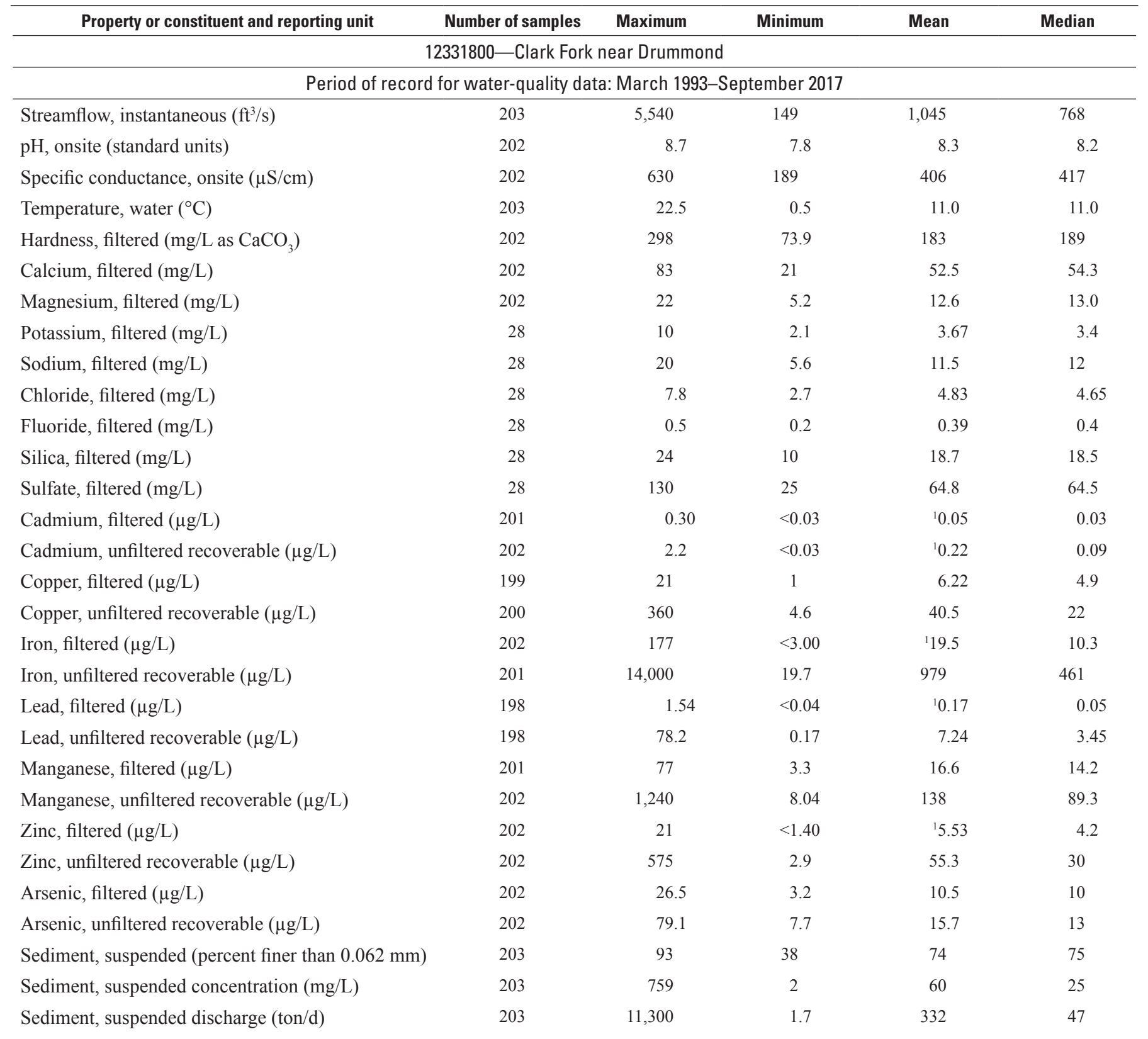


Table 21. Statistical summary of long-term water-quality data for the Clark Fork Basin, Montana, March 1985 through September 2017.-Continued

$\left[\mathrm{ft}^{3} / \mathrm{s}\right.$, cubic foot per second; $\mu \mathrm{S} / \mathrm{cm}$, microsiemens per centimeter at 25 degrees Celsius; ${ }^{\circ} \mathrm{C}$, degrees Celsius; lab, laboratory; NTRU, nephelometric turbidity ratio unit; $<$, less than laboratory reporting level ${ }^{1} ; \mathrm{mg} / \mathrm{L}$, milligram per liter; $\mathrm{CaCO}_{3}$, calcium carbonate; $\mu \mathrm{g} / \mathrm{L}$, microgram per liter; $\mathrm{mm}$, millimeter; ton/d, ton per day; --, no data]

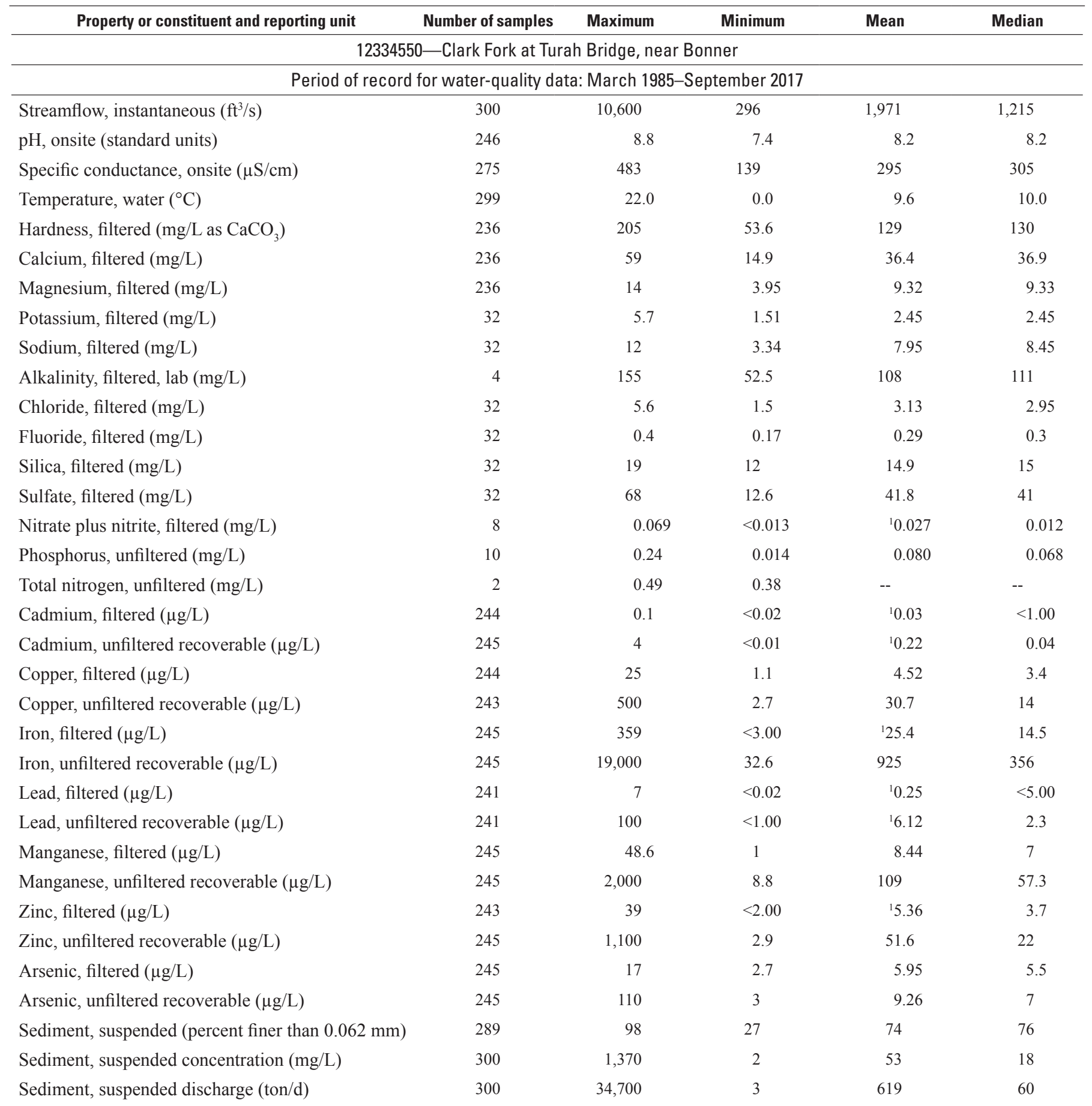


Table 21. Statistical summary of long-term water-quality data for the Clark Fork Basin, Montana, March 1985 through September 2017.-Continued

$\left[\mathrm{ft}^{3} / \mathrm{s}\right.$, cubic foot per second; $\mu \mathrm{S} / \mathrm{cm}$, microsiemens per centimeter at 25 degrees Celsius; ${ }^{\circ} \mathrm{C}$, degrees Celsius; lab, laboratory; NTRU, nephelometric turbidity ratio unit; <, less than laboratory reporting level ${ }^{1} ; \mathrm{mg} / \mathrm{L}$, milligram per liter; $\mathrm{CaCO}_{3}$, calcium carbonate; $\mu \mathrm{g} / \mathrm{L}$, microgram per liter; mm, millimeter; ton/d, ton per day; --, no data]

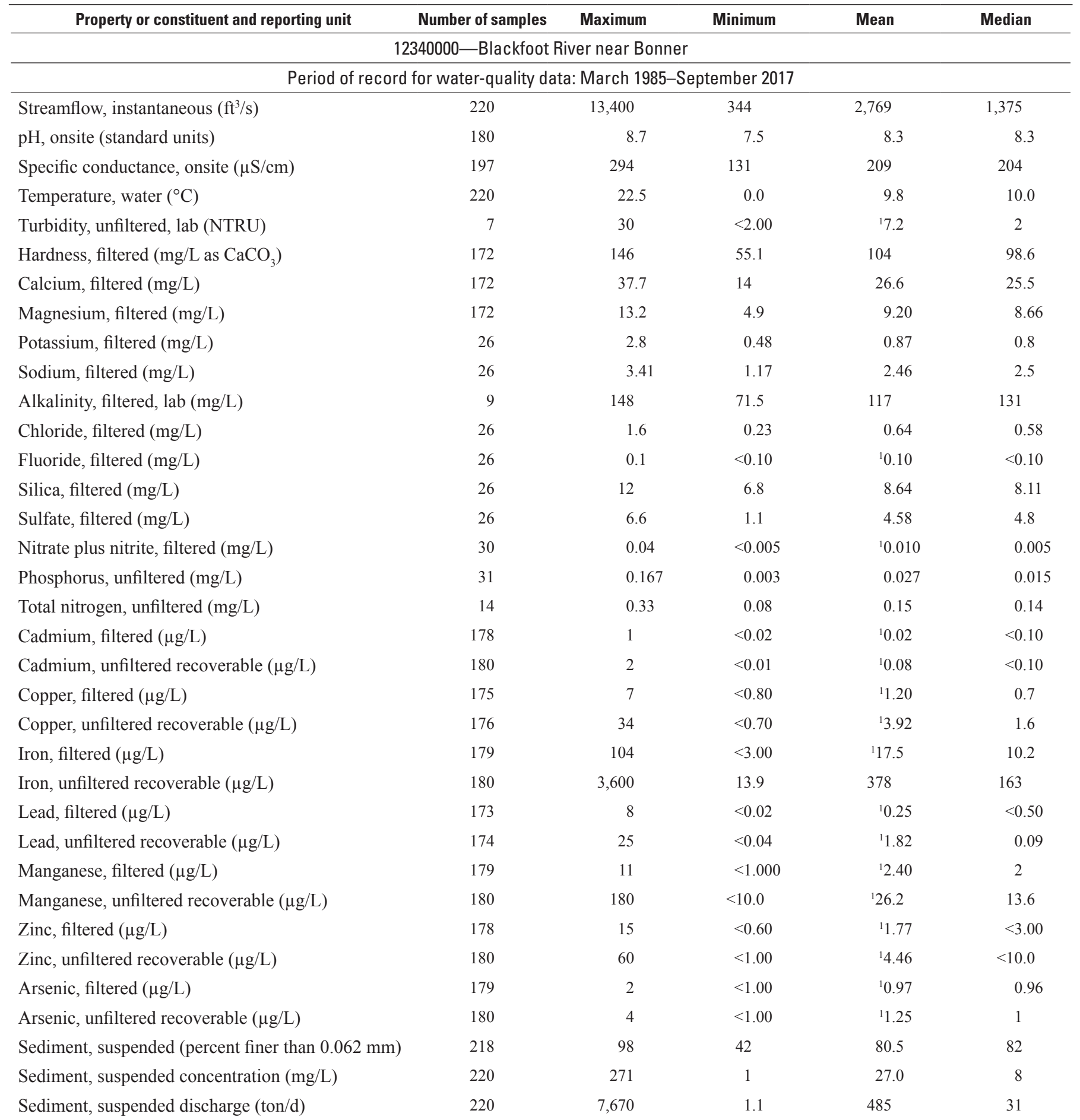


Table 21. Statistical summary of long-term water-quality data for the Clark Fork Basin, Montana, March 1985 through September 2017.-Continued

$\left[\mathrm{ft}^{3} / \mathrm{s}\right.$, cubic foot per second; $\mu \mathrm{S} / \mathrm{cm}$, microsiemens per centimeter at 25 degrees Celsius; ${ }^{\circ} \mathrm{C}$, degrees Celsius; lab, laboratory; NTRU, nephelometric turbidity ratio unit; <, less than laboratory reporting level ${ }^{1} ; \mathrm{mg} / \mathrm{L}$, milligram per liter; $\mathrm{CaCO}_{3}$, calcium carbonate; $\mu \mathrm{g} / \mathrm{L}$, microgram per liter; $\mathrm{mm}$, millimeter; ton/d, ton per day; --, no data]

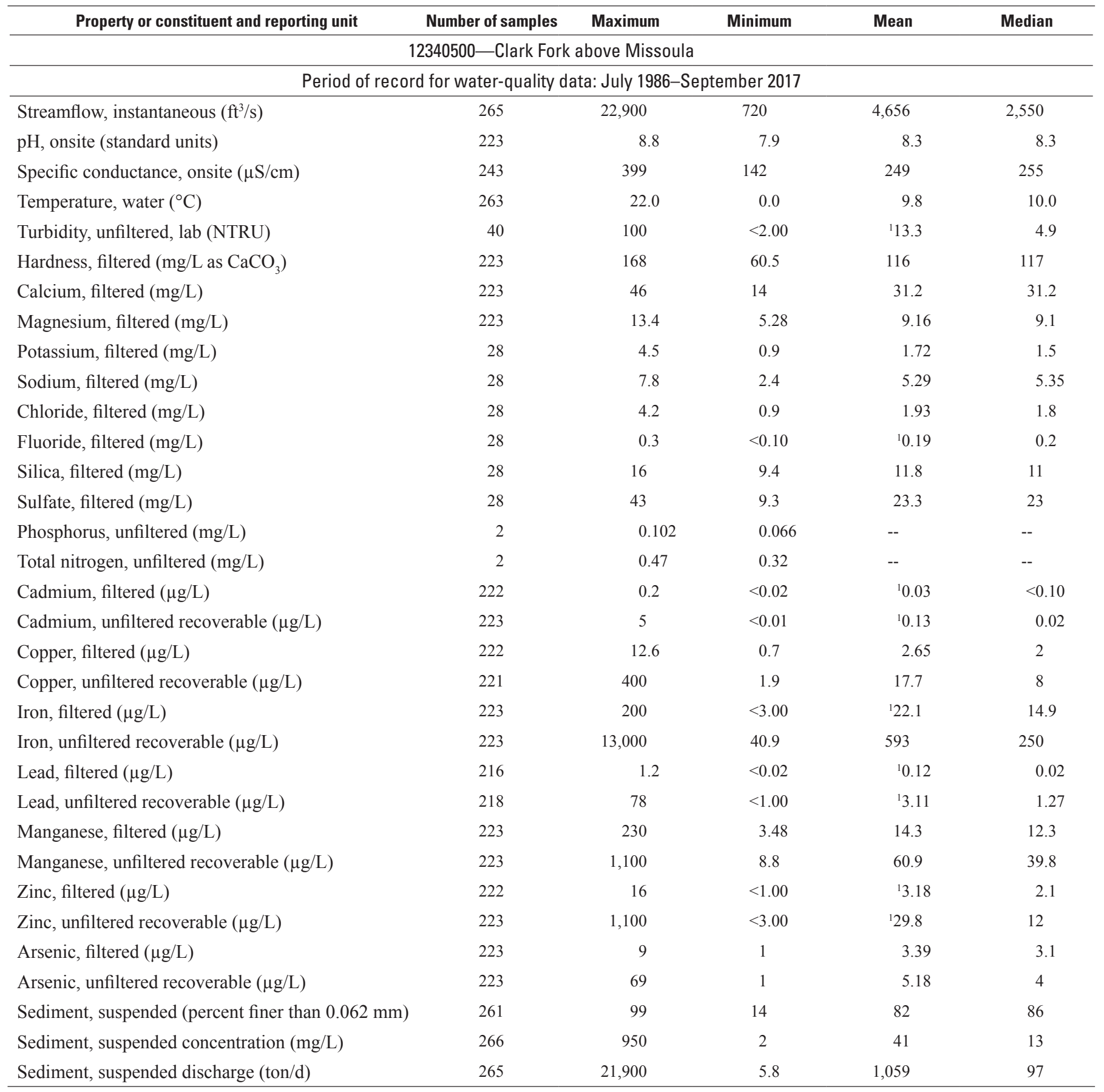

${ }^{1}$ Value for the mean is estimated using a log-probability regression to predict the values of data less than the laboratory reporting level (Helsel and Cohn, 1988). 
Table 22. Statistical summary of long-term bed-sediment data for the Clark Fork Basin, Montana, August 1986 through August 2017.

[Reported concentrations are in micrograms per gram dry weight. Number of samples represents the number of years that the constituent was analyzed, with each year represented by a single mean concentration of composite samples. Arsenic was not analyzed until 2003; therefore, the number of samples is smaller than that for the other trace elements. Analysis of samples for silver was discontinued in 2004; therefore, the number of samples is smaller than that for other trace elements. <, less than the minimum reporting level; --, indicates insufficient data (less than three samples) to compute statistic]

\begin{tabular}{|c|c|c|c|c|c|}
\hline Constituent & Number of samples & Maximum & Minimum & Mean & Median \\
\hline \multicolumn{6}{|c|}{$\begin{array}{l}12323600 \text {-Silver Bow Creek at Opportunity } \\
\text { Period of record for bed-sediment data: 1992-2017 }\end{array}$} \\
\hline Cadmium & 26 & 43.9 & 5.9 & 24.2 & 25.8 \\
\hline Chromium & 24 & 50.7 & 16.8 & 29.0 & 25.9 \\
\hline Lead & 26 & 1,030 & 93.0 & 501 & 492 \\
\hline Manganese & 26 & 9,220 & 1,160 & 3,270 & 2,840 \\
\hline Nickel & 25 & 21.4 & 12.0 & 14.9 & 14.8 \\
\hline Silver & 12 & 20.0 & 8.3 & 15.5 & 15.8 \\
\hline
\end{tabular}

12323750 - Silver Bow Creek at Warm Springs

Period of record for bed-sediment data: 1992-2017

\begin{tabular}{|c|c|c|c|c|c|}
\hline Arsenic & 15 & 177 & 66.5 & 109 & 98 \\
\hline Cadmium & 26 & 12.2 & 4.2 & 6.8 & 6.2 \\
\hline Chromium & 24 & 46.8 & $<15.7$ & ${ }^{1} 23.5$ & ${ }^{1} 22.4$ \\
\hline Copper & 26 & 769 & 169 & 332 & 290 \\
\hline Iron & 26 & 32,500 & 15,400 & 23,800 & 23,400 \\
\hline Lead & 26 & 121 & 49.5 & 73.5 & 73.1 \\
\hline Manganese & 26 & 17,700 & 1,470 & 7,220 & 7,210 \\
\hline Nickel & 25 & 20.0 & 9.2 & 14.9 & 14.7 \\
\hline Silver & 12 & 4.4 & 0.3 & ${ }^{1} 1.9$ & ${ }^{1} 1.8$ \\
\hline Zinc & 26 & 2,220 & 554 & 863 & 681 \\
\hline
\end{tabular}

12323770 - Warm Springs Creek at Warm Springs

Period of record for bed-sediment data: 1995, 1997, 1999, 2002, 2005, 2008, 2011, 2014, 2017

\begin{tabular}{|c|c|c|c|c|c|}
\hline Arsenic & 5 & 66.1 & 34.0 & 55.3 & 59.6 \\
\hline Cadmium & 9 & 5.8 & 1.2 & 3.1 & 2.8 \\
\hline Chromium & 9 & 39.3 & 24.1 & 31.1 & 31.4 \\
\hline Copper & 9 & 1,060 & 496 & 831 & 848 \\
\hline Iron & 9 & 26,600 & 16,800 & 21,600 & 22,000 \\
\hline Lead & 9 & 85.6 & 42.3 & 75.6 & 79.3 \\
\hline Manganese & 9 & 12,100 & 555 & 6,190 & 6,030 \\
\hline Nickel & 9 & 34.3 & 14.5 & 21.2 & 19.6 \\
\hline Silver & 4 & 5.1 & 3.1 & 3.8 & 3.5 \\
\hline Zinc & 9 & 453 & 237 & 386 & 396 \\
\hline
\end{tabular}


Table 22. Statistical summary of long-term bed-sediment data for the Clark Fork Basin, Montana, August 1986 through August 2017.Continued

[Reported concentrations are in micrograms per gram dry weight. Number of samples represents the number of years that the constituent was analyzed, with each year represented by a single mean concentration of composite samples. Arsenic was not analyzed until 2003; therefore, the number of samples is smaller than that for the other trace elements. Analysis of samples for silver was discontinued in 2004; therefore, the number of samples is smaller than that for other trace elements. <, less than the minimum reporting level; --, indicates insufficient data (less than three samples) to compute statistic]

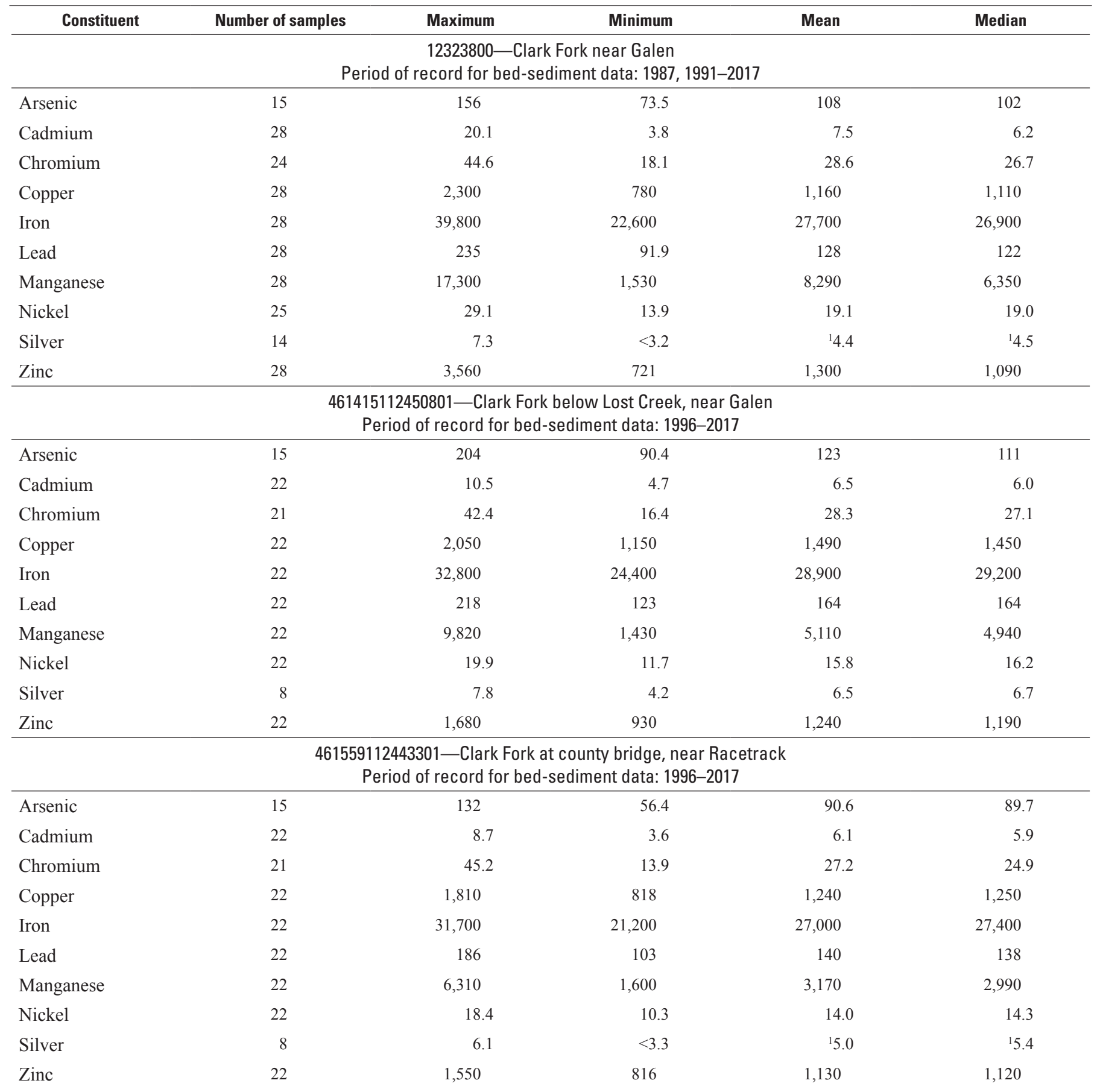


Table 22. Statistical summary of long-term bed-sediment data for the Clark Fork Basin, Montana, August 1986 through August 2017.Continued

[Reported concentrations are in micrograms per gram dry weight. Number of samples represents the number of years that the constituent was analyzed, with each year represented by a single mean concentration of composite samples. Arsenic was not analyzed until 2003; therefore, the number of samples is smaller than that for the other trace elements. Analysis of samples for silver was discontinued in 2004; therefore, the number of samples is smaller than that for other trace elements. <, less than the minimum reporting level; --, indicates insufficient data (less than three samples) to compute statistic]

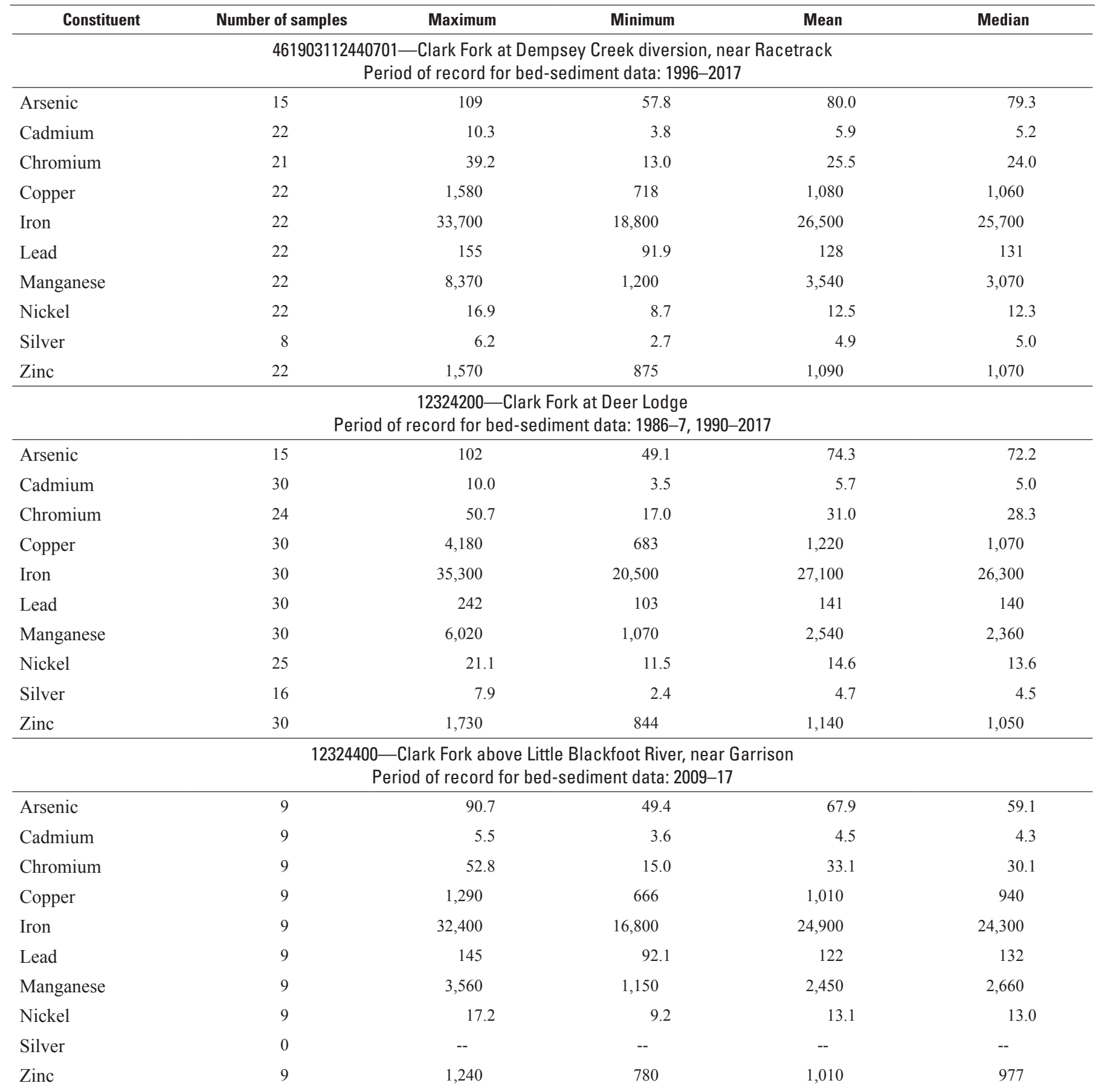


Table 22. Statistical summary of long-term bed-sediment data for the Clark Fork Basin, Montana, August 1986 through August 2017.Continued

[Reported concentrations are in micrograms per gram dry weight. Number of samples represents the number of years that the constituent was analyzed, with each year represented by a single mean concentration of composite samples. Arsenic was not analyzed until 2003; therefore, the number of samples is smaller than that for the other trace elements. Analysis of samples for silver was discontinued in 2004; therefore, the number of samples is smaller than that for other trace elements. <, less than the minimum reporting level; --, indicates insufficient data (less than three samples) to compute statistic]

\begin{tabular}{|c|c|c|c|c|c|}
\hline Constituent & Number of samples & Maximum & Minimum & Mean & Median \\
\hline \multicolumn{6}{|c|}{$\begin{array}{l}12324680 \text { - Clark Fork at Goldcreek } \\
\text { Period of record for bed-sediment data: } 1992-2017\end{array}$} \\
\hline Cadmium & 26 & 8.1 & 2.0 & 4.2 & 3.8 \\
\hline Chromium & 24 & 55.3 & 9.9 & 31.0 & 28.8 \\
\hline Lead & 26 & 152 & 45.4 & 90.6 & 92.2 \\
\hline Manganese & 26 & 2,730 & 977 & 1,820 & 1,810 \\
\hline Nickel & 25 & 18.6 & 7.6 & 13.3 & 13.3 \\
\hline Silver & 12 & 4.8 & 2.3 & 3.2 & 3.2 \\
\hline
\end{tabular}

12331800 - Clark Fork near Drummond

Period of record for bed-sediment data: 1986-7, 1991-2017

\begin{tabular}{|c|c|c|c|c|c|}
\hline Arsenic & 15 & 66.2 & 17.2 & 37.1 & 32.8 \\
\hline Cadmium & 29 & 7.7 & 1.7 & 4.1 & 4.1 \\
\hline Chromium & 24 & 41.9 & 9.2 & 26.5 & 26.1 \\
\hline Copper & 29 & 747 & 183 & 459 & 443 \\
\hline Iron & 29 & 44,000 & 14,800 & 24,200 & 20,400 \\
\hline Lead & 29 & 135 & 26.8 & 83.0 & 82.0 \\
\hline Manganese & 29 & 4,820 & 832 & 1,990 & 1,810 \\
\hline Nickel & 25 & 16.8 & 4.8 & 12.6 & 13.0 \\
\hline Silver & 15 & 4.7 & $<3.2$ & 13.0 & 12.9 \\
\hline Zinc & 29 & 1,230 & 380 & 900 & 947 \\
\hline \multicolumn{6}{|c|}{$\begin{array}{l}\text { 12334550 - Clark Fork at Turah Bridge, near Bonner } \\
\text { Period of record for bed-sediment data: 1986, 1991-2017 }\end{array}$} \\
\hline Arsenic & 15 & 43.1 & 17.3 & 26.0 & 24.8 \\
\hline Cadmium & 28 & 7.3 & 1.2 & 3.1 & 3.1 \\
\hline Chromium & 24 & 42.5 & 13.6 & 25.8 & 25.4 \\
\hline Copper & 28 & 635 & 211 & 334 & 320 \\
\hline Iron & 28 & 25,900 & 12,600 & 19,000 & 17,300 \\
\hline Lead & 28 & 115 & 37.4 & 63.9 & 60.4 \\
\hline Manganese & 28 & 2,340 & 383 & 1,200 & 1,180 \\
\hline Nickel & 25 & 19.1 & 6.9 & 12.2 & 11.5 \\
\hline Silver & 14 & 3.9 & $<1.9$ & 12.1 & ${ }^{1} 1.9$ \\
\hline Zinc & 28 & 1,160 & 448 & 747 & 742 \\
\hline
\end{tabular}


Table 22. Statistical summary of long-term bed-sediment data for the Clark Fork Basin, Montana, August 1986 through August 2017.Continued

[Reported concentrations are in micrograms per gram dry weight. Number of samples represents the number of years that the constituent was analyzed, with each year represented by a single mean concentration of composite samples. Arsenic was not analyzed until 2003; therefore, the number of samples is smaller than that for the other trace elements. Analysis of samples for silver was discontinued in 2004; therefore, the number of samples is smaller than that for other trace elements. <, less than the minimum reporting level; --, indicates insufficient data (less than three samples) to compute statistic]

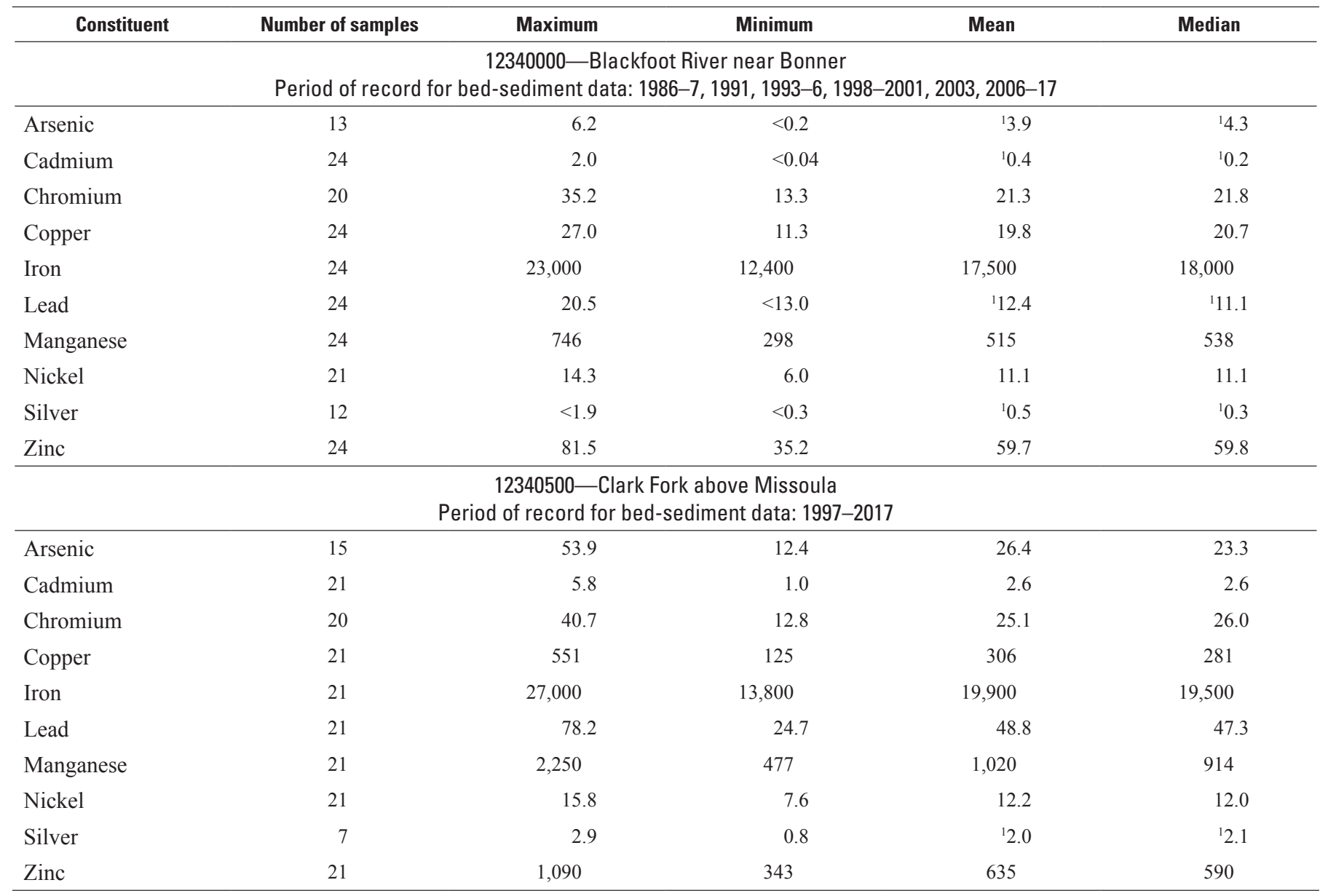

${ }^{1}$ Value determined by substituting one-half of the minimum reporting level for censored $(<)$ values when both uncensored and censored values were used to determine the mean and median. 
Table 23. Statistical summary of long-term biological data for the Clark Fork Basin, Montana, August 1986 through August 2017.

[Reported concentrations are in micrograms per gram dry weight. Number of composite samples represents the total of all individual composite samples collected for every year that the constituent was analyzed. Values for a single sample are arbitrarily listed in the "Mean" column. Because Hydropsyche insects were not sorted to the species level during 1986-9, Hydropsyche species statistics for stations sampled during those years are based on the results of all Hydropsyche species combined. At some sites, statistics of the Hydropsyche morosa group are based on the combined results of two or more species. Insects collected during 1986-98 were depurated before analysis; depuration was discontinued in 1999. Arsenic was not analyzed until 2003; therefore, the number of samples may be small or zero for some taxa. spp., one or more similar species; --, indicates either too few samples (less than three) or insufficient data to compute statistic, or element not analyzed; <, less than minimum reporting level]

\begin{tabular}{|c|c|c|c|c|c|}
\hline Constituent & $\begin{array}{c}\text { Number of composite } \\
\text { samples }\end{array}$ & Maximum & Minimum & Mean & Median \\
\hline \multicolumn{6}{|c|}{$\begin{array}{c}12323600 \text {-Silver Bow Creek at Opportunity } \\
\text { Period of record for biological data: 1992, 1994-5, 1997-2017 }\end{array}$} \\
\hline \multicolumn{6}{|c|}{ Brachycentrus spp. } \\
\hline Arsenic & 0 & -- & -- & -- & -- \\
\hline Cadmium & 5 & 12.5 & 5.8 & 10.1 & 11.6 \\
\hline Copper & 5 & 846 & 235 & 587 & 592 \\
\hline Iron & 5 & 1,190 & 335 & 617 & 469 \\
\hline Lead & 5 & 21.5 & 7.4 & 13.7 & 13.8 \\
\hline Manganese & 5 & 817 & 231 & 515 & 503 \\
\hline Arsenic & 30 & 33.3 & 4.3 & 10.4 & 7.3 \\
\hline Cadmium & 36 & 9.7 & 2.4 & 4.8 & 4.5 \\
\hline Chromium & 36 & 25.5 & 1.0 & 4.1 & 3.9 \\
\hline Copper & 36 & 1,090 & 78.6 & 290 & 271 \\
\hline Iron & 36 & 6,160 & 689 & 2,680 & 2,440 \\
\hline Lead & 36 & 74.3 & 11.2 & 29.3 & 20.9 \\
\hline Manganese & 36 & 4,000 & 180 & 1,400 & 1,190 \\
\hline Nickel & 36 & 4.3 & 0.7 & 2.8 & 3.1 \\
\hline Zinc & 36 & 1,590 & 432 & 756 & 739 \\
\hline Lead & 20 & 237 & 9.4 & 43.7 & 36.0 \\
\hline Manganese & 20 & 2,750 & 612 & 1,130 & 1,050 \\
\hline Nickel & 20 & 4.1 & 0.7 & 2.2 & 2.4 \\
\hline Zinc & 20 & 1,290 & 380 & 850 & 855 \\
\hline
\end{tabular}


Table 23. Statistical summary of long-term biological data for the Clark Fork Basin, Montana, August 1986 through August 2017.Continued

[Reported concentrations are in micrograms per gram dry weight. Number of composite samples represents the total of all individual composite samples collected for every year that the constituent was analyzed. Values for a single sample are arbitrarily listed in the "Mean" column. Because Hydropsyche insects were not sorted to the species level during 1986-9, Hydropsyche species statistics for stations sampled during those years are based on the results of all Hydropsyche species combined. At some sites, statistics of the Hydropsyche morosa group are based on the combined results of two or more species. Insects collected during 1986-98 were depurated before analysis; depuration was discontinued in 1999. Arsenic was not analyzed until 2003; therefore, the number of samples may be small or zero for some taxa. spp., one or more similar species; --, indicates either too few samples (less than three) or insufficient data to compute statistic, or element not analyzed; <, less than minimum reporting level]

\begin{tabular}{|c|c|c|c|c|c|}
\hline Constituent & $\begin{array}{l}\text { Number of composite } \\
\text { samples }\end{array}$ & Maximum & Minimum & Mean & Median \\
\hline \multicolumn{6}{|c|}{$\begin{array}{l}12323600 \text { - Silver Bow Creek at Opportunity-Continued } \\
\text { Period of record for biological data: 1992, 1994-5, 1997-2017 }\end{array}$} \\
\hline \multicolumn{6}{|c|}{ Hydropsyche tana } \\
\hline Arsenic & 0 & -- & -- & -- & -- \\
\hline Cadmium & 6 & 9.2 & 4.8 & 6.8 & 6.9 \\
\hline Copper & 6 & 456 & 10.5 & 236 & 298 \\
\hline Iron & 6 & 1,520 & 875 & 1,100 & 1,050 \\
\hline Lead & 6 & 21.0 & 15.6 & 18.6 & 18.3 \\
\hline Manganese & 6 & 969 & 307 & 634 & 675 \\
\hline
\end{tabular}

12323750 - Silver Bow Creek at Warm Springs

Period of record for biological data: 1992-2017

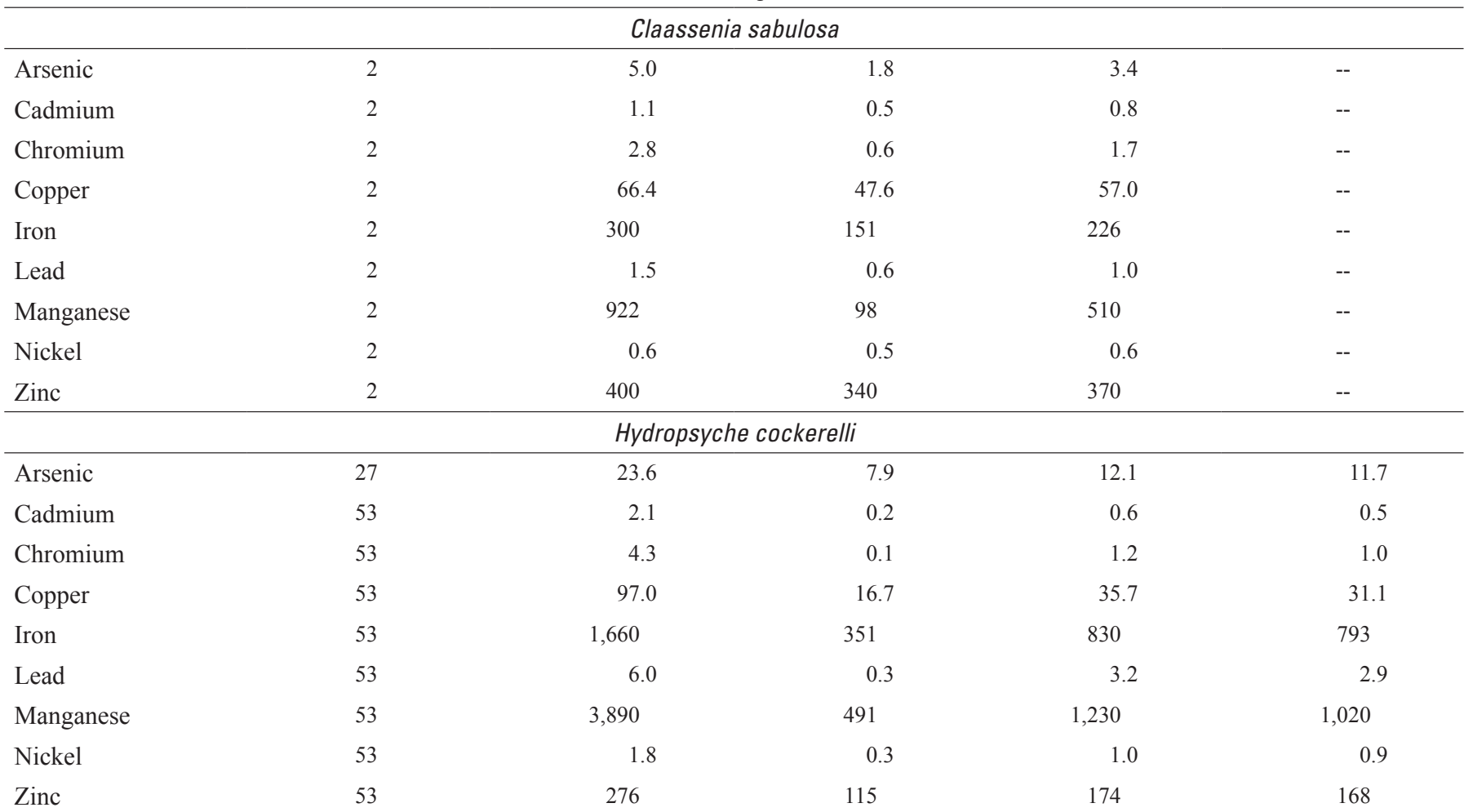


Table 23. Statistical summary of long-term biological data for the Clark Fork Basin, Montana, August 1986 through August 2017.Continued

[Reported concentrations are in micrograms per gram dry weight. Number of composite samples represents the total of all individual composite samples collected for every year that the constituent was analyzed. Values for a single sample are arbitrarily listed in the "Mean" column. Because Hydropsyche insects were not sorted to the species level during 1986-9, Hydropsyche species statistics for stations sampled during those years are based on the results of all Hydropsyche species combined. At some sites, statistics of the Hydropsyche morosa group are based on the combined results of two or more species. Insects collected during 1986-98 were depurated before analysis; depuration was discontinued in 1999. Arsenic was not analyzed until 2003; therefore, the number of samples may be small or zero for some taxa. spp., one or more similar species; --, indicates either too few samples (less than three) or insufficient data to compute statistic, or element not analyzed; <, less than minimum reporting level]

\begin{tabular}{|c|c|c|c|c|c|}
\hline Constituent & $\begin{array}{l}\text { Number of composite } \\
\text { samples }\end{array}$ & Maximum & Minimum & Mean & Median \\
\hline \multicolumn{6}{|c|}{$\begin{array}{l}\text { 12323750_Silver Bow Creek at Warm Springs_-Continued } \\
\text { Period of record for biological data: 1992-2017 }\end{array}$} \\
\hline \multicolumn{6}{|c|}{ Hydropsyche occidentalis } \\
\hline Arsenic & 11 & 31.0 & 10.5 & 18.6 & 15.6 \\
\hline Copper & 26 & 48.9 & 11.0 & 34.0 & 33.0 \\
\hline Iron & 26 & 2,960 & 372 & 1,280 & 1,020 \\
\hline Lead & 26 & 8.2 & $<1.7$ & ${ }^{1} 4.1$ & ${ }^{1} 3.8$ \\
\hline Manganese & 26 & 6,940 & 996 & 2,400 & 2,040 \\
\hline Arsenic & 1 & -- & -- & 14.0 & -- \\
\hline Cadmium & 5 & 2.3 & 0.4 & 1.0 & 0.6 \\
\hline Chromium & 5 & 2.5 & 0.5 & 1.4 & 1.3 \\
\hline Copper & 5 & 47.6 & 34.9 & 39.9 & 40.4 \\
\hline Iron & 5 & 1,100 & 561 & 763 & 767 \\
\hline Lead & 5 & 5.1 & 1.9 & 4.0 & 4.5 \\
\hline Manganese & 5 & 1,190 & 443 & 817 & 804 \\
\hline Nickel & 5 & 1.9 & $<0.4$ & ${ }^{1} 1.0$ & ${ }^{1} 0.8$ \\
\hline Zinc & 5 & 284 & 141 & 188 & 162 \\
\hline
\end{tabular}

12323770 - Warm Springs Creek at Warm Springs

Period of record for biological data: 1995, 1997, 1999, 2002, 2005, 2008, 2011, 2014, 2017

\begin{tabular}{|c|c|c|c|c|c|}
\hline \multicolumn{6}{|c|}{ Arctopsyche grandis } \\
\hline Arsenic & 7 & 9.8 & 7.6 & 8.7 & 8.4 \\
\hline Cadmium & 11 & 3.6 & 0.4 & 2.5 & 2.6 \\
\hline Copper & 11 & 133 & 53.2 & 104 & 102 \\
\hline Iron & 11 & 1,490 & 684 & 1,080 & 1,050 \\
\hline Manganese & 11 & 3,560 & 738 & 2,120 & 1,800 \\
\hline Nickel & 11 & 7.5 & 1.1 & ${ }^{1} 3.7$ & ${ }^{12} 2.8$ \\
\hline Zinc & 11 & 331 & 181 & 228 & 200 \\
\hline
\end{tabular}


Table 23. Statistical summary of long-term biological data for the Clark Fork Basin, Montana, August 1986 through August 2017.Continued

[Reported concentrations are in micrograms per gram dry weight. Number of composite samples represents the total of all individual composite samples collected for every year that the constituent was analyzed. Values for a single sample are arbitrarily listed in the "Mean" column. Because Hydropsyche insects were not sorted to the species level during 1986-9, Hydropsyche species statistics for stations sampled during those years are based on the results of all Hydropsyche species combined. At some sites, statistics of the Hydropsyche morosa group are based on the combined results of two or more species. Insects collected during 1986-98 were depurated before analysis; depuration was discontinued in 1999. Arsenic was not analyzed until 2003; therefore, the number of samples may be small or zero for some taxa. spp., one or more similar species; --, indicates either too few samples (less than three) or insufficient data to compute statistic, or element not analyzed; <, less than minimum reporting level]

\begin{tabular}{|c|c|c|c|c|c|}
\hline Constituent & $\begin{array}{l}\text { Number of composite } \\
\text { samples }\end{array}$ & Maximum & Minimum & Mean & Median \\
\hline \multicolumn{6}{|c|}{$\begin{array}{l}\text { 12323770-Warm Springs Creek at Warm Springs-Continued } \\
\text { Period of record for biological data: 1995, 1997, 1999, 2002, 2005, 2008, 2011, 2014, } 2017\end{array}$} \\
\hline \multicolumn{6}{|c|}{ Hesperoperla spp. } \\
\hline Arsenic & 4 & 2.9 & 1.2 & 2.2 & 2.4 \\
\hline Cadmium & 4 & 2.6 & 0.5 & 1.3 & 1.1 \\
\hline Copper & 4 & 64.9 & 44.2 & 56.4 & 58.2 \\
\hline Iron & 4 & 456 & 375 & 409 & 403 \\
\hline Lead & 4 & 1.9 & 1.4 & 1.6 & 1.6 \\
\hline Manganese & 4 & 356 & 202 & 284 & 289 \\
\hline \multicolumn{6}{|c|}{ Hydropsyche occidentalis } \\
\hline Arsenic & 4 & 13.6 & 9.8 & 12.4 & 13.0 \\
\hline Cadmium & 6 & 1.4 & 0.7 & 1.1 & 1.2 \\
\hline Chromium & 6 & 8.6 & 0.3 & 3.7 & 3.2 \\
\hline Copper & 6 & 183 & 116 & 151 & 150 \\
\hline Iron & 6 & 2,360 & 1,520 & 1,870 & 1,840 \\
\hline Lead & 6 & 12.6 & 6.7 & 8.2 & 7.4 \\
\hline Manganese & 6 & 3,190 & 1,440 & 2,580 & 2,680 \\
\hline Nickel & 6 & 4.5 & 2.0 & 3.1 & 3.2 \\
\hline Zinc & 6 & 204 & 148 & 169 & 168 \\
\hline \multicolumn{6}{|c|}{ Hydropsyche spp. } \\
\hline Arsenic & 1 & -- & -- & 13.1 & -- \\
\hline Cadmium & 3 & 1.3 & 0.6 & 1.0 & 1.1 \\
\hline Chromium & 3 & 3.5 & 1.4 & 2.2 & 1.6 \\
\hline Copper & 3 & 155 & 94.8 & 115 & 95.9 \\
\hline Iron & 3 & 2,260 & 1,150 & 1,540 & 1,220 \\
\hline Lead & 3 & 11.3 & 5.2 & 7.5 & 5.9 \\
\hline Manganese & 3 & 3,390 & 956 & 2,120 & 2,030 \\
\hline Nickel & 3 & 8.8 & 1.8 & 4.2 & 2.0 \\
\hline Zinc & 3 & 214 & 125 & 156 & 129 \\
\hline
\end{tabular}


Table 23. Statistical summary of long-term biological data for the Clark Fork Basin, Montana, August 1986 through August 2017.Continued

[Reported concentrations are in micrograms per gram dry weight. Number of composite samples represents the total of all individual composite samples collected for every year that the constituent was analyzed. Values for a single sample are arbitrarily listed in the "Mean" column. Because Hydropsyche insects were not sorted to the species level during 1986-9, Hydropsyche species statistics for stations sampled during those years are based on the results of all Hydropsyche species combined. At some sites, statistics of the Hydropsyche morosa group are based on the combined results of two or more species. Insects collected during 1986-98 were depurated before analysis; depuration was discontinued in 1999. Arsenic was not analyzed until 2003; therefore, the number of samples may be small or zero for some taxa. spp., one or more similar species; --, indicates either too few samples (less than three) or insufficient data to compute statistic, or element not analyzed; <, less than minimum reporting level]

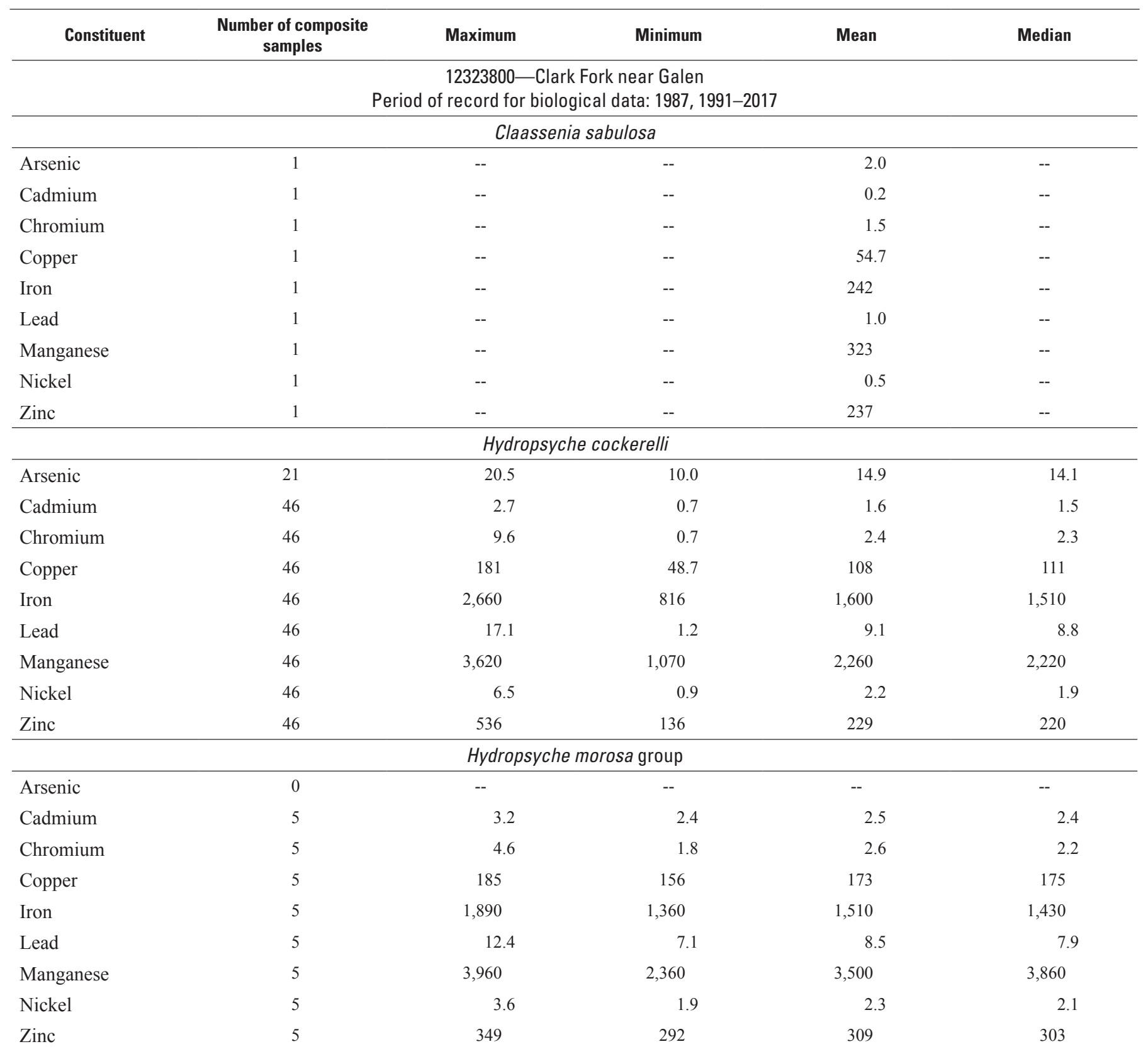


Table 23. Statistical summary of long-term biological data for the Clark Fork Basin, Montana, August 1986 through August 2017.Continued

[Reported concentrations are in micrograms per gram dry weight. Number of composite samples represents the total of all individual composite samples collected for every year that the constituent was analyzed. Values for a single sample are arbitrarily listed in the "Mean" column. Because Hydropsyche insects were not sorted to the species level during 1986-9, Hydropsyche species statistics for stations sampled during those years are based on the results of all Hydropsyche species combined. At some sites, statistics of the Hydropsyche morosa group are based on the combined results of two or more species. Insects collected during 1986-98 were depurated before analysis; depuration was discontinued in 1999. Arsenic was not analyzed until 2003; therefore, the number of samples may be small or zero for some taxa. spp., one or more similar species; --, indicates either too few samples (less than three) or insufficient data to compute statistic, or element not analyzed; <, less than minimum reporting level]

\begin{tabular}{|c|c|c|c|c|c|}
\hline Constituent & $\begin{array}{c}\text { Number of composite } \\
\text { samples }\end{array}$ & Maximum & Minimum & Mean & Median \\
\hline \multicolumn{6}{|c|}{$\begin{array}{c}12323800 \text {-Clark Fork near Galen-Continued } \\
\text { Period of record for biological data: 1987, 1991-2017 }\end{array}$} \\
\hline \multicolumn{6}{|c|}{ Hydropsyche occidentalis } \\
\hline Arsenic & 23 & 17.7 & 9.1 & 14.3 & 14.6 \\
\hline Cadmium & 55 & 1.6 & 0.6 & 1.1 & 1.2 \\
\hline Copper & 55 & 151 & 49.2 & 95.1 & 93.1 \\
\hline Iron & 55 & 2,590 & 642 & 1,520 & 1,450 \\
\hline Lead & 55 & 13.5 & 1.6 & 8.3 & 8.4 \\
\hline Manganese & 55 & 6,170 & 653 & 2,490 & 2,230 \\
\hline Arsenic & 0 & -- & -- & -- & -- \\
\hline Cadmium & 1 & -- & -- & 1.5 & -- \\
\hline Chromium & 1 & -- & -- & 1.4 & -- \\
\hline Copper & 1 & -- & -- & 92.9 & -- \\
\hline Iron & 1 & -- & -- & 1,340 & -- \\
\hline Lead & 1 & -- & -- & 9.0 & -- \\
\hline Manganese & 1 & -- & -- & 2,160 & -- \\
\hline Nickel & 1 & -- & -- & 2.1 & -- \\
\hline Zinc & 1 & -- & -- & 206 & -- \\
\hline \multicolumn{6}{|c|}{ Hydropsyche spp. } \\
\hline Arsenic & 6 & 15.7 & 5.5 & 10.5 & 10.7 \\
\hline Cadmium & 10 & 3.5 & 0.7 & 1.8 & 1.3 \\
\hline Chromium & 6 & 2.4 & 0.6 & 1.6 & 1.6 \\
\hline Copper & 10 & 154 & 55.3 & 105 & 105 \\
\hline Iron & 10 & 2,110 & 914 & 1,320 & 1,260 \\
\hline Lead & 10 & 13.5 & 3.8 & 8.7 & 9.2 \\
\hline Manganese & 6 & 4,760 & 668 & 2,330 & 1,720 \\
\hline Nickel & 6 & 3.9 & 0.9 & 2.0 & 1.6 \\
\hline Zinc & 10 & 329 & 132 & 236 & 223 \\
\hline
\end{tabular}


Table 23. Statistical summary of long-term biological data for the Clark Fork Basin, Montana, August 1986 through August 2017.Continued

[Reported concentrations are in micrograms per gram dry weight. Number of composite samples represents the total of all individual composite samples collected for every year that the constituent was analyzed. Values for a single sample are arbitrarily listed in the "Mean" column. Because Hydropsyche insects were not sorted to the species level during 1986-9, Hydropsyche species statistics for stations sampled during those years are based on the results of all Hydropsyche species combined. At some sites, statistics of the Hydropsyche morosa group are based on the combined results of two or more species. Insects collected during 1986-98 were depurated before analysis; depuration was discontinued in 1999. Arsenic was not analyzed until 2003; therefore, the number of samples may be small or zero for some taxa. spp., one or more similar species; --, indicates either too few samples (less than three) or insufficient data to compute statistic, or element not analyzed; <, less than minimum reporting level]

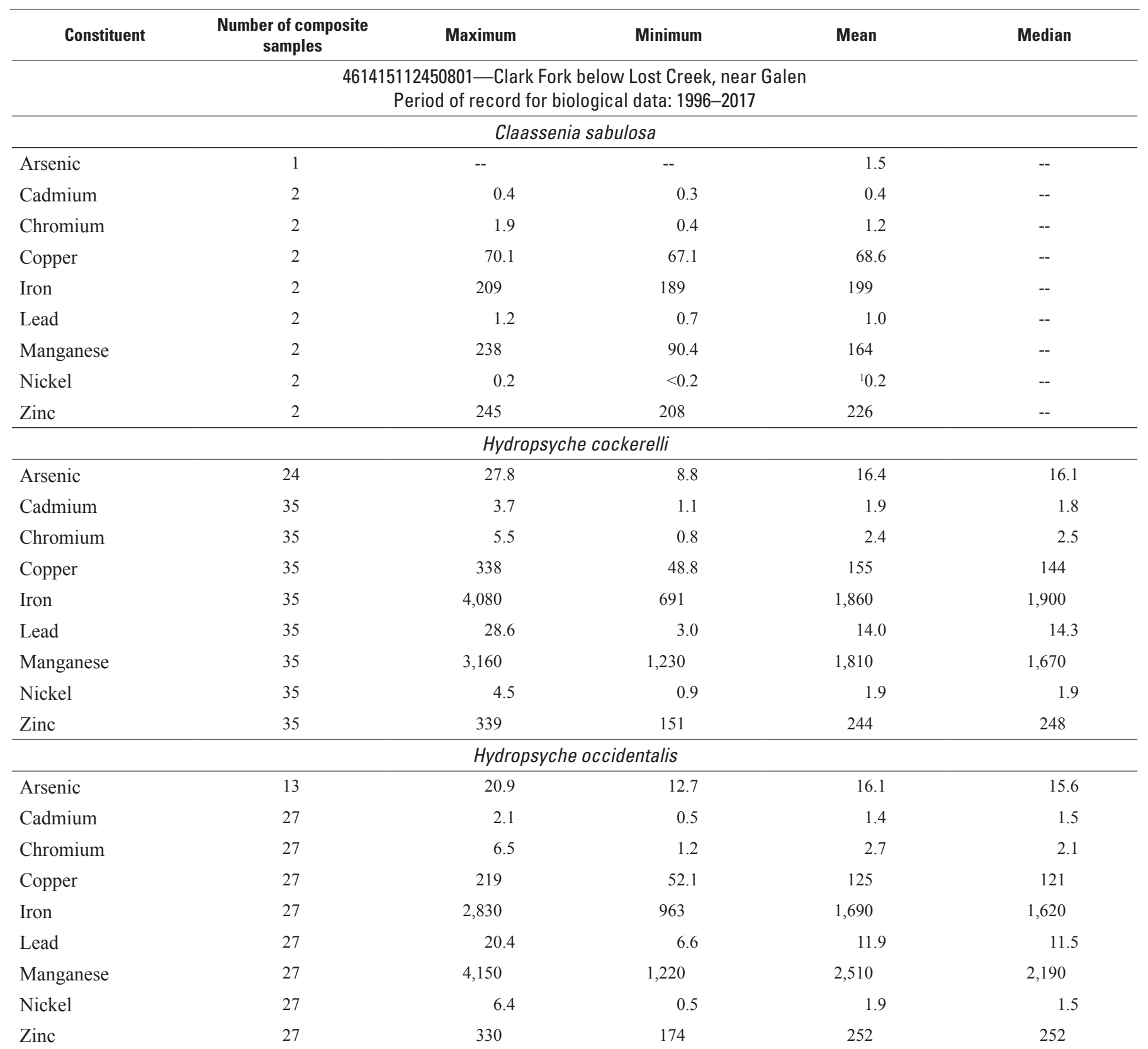


Table 23. Statistical summary of long-term biological data for the Clark Fork Basin, Montana, August 1986 through August 2017.Continued

[Reported concentrations are in micrograms per gram dry weight. Number of composite samples represents the total of all individual composite samples collected for every year that the constituent was analyzed. Values for a single sample are arbitrarily listed in the "Mean" column. Because Hydropsyche insects were not sorted to the species level during 1986-9, Hydropsyche species statistics for stations sampled during those years are based on the results of all Hydropsyche species combined. At some sites, statistics of the Hydropsyche morosa group are based on the combined results of two or more species. Insects collected during 1986-98 were depurated before analysis; depuration was discontinued in 1999. Arsenic was not analyzed until 2003; therefore, the number of samples may be small or zero for some taxa. spp., one or more similar species; --, indicates either too few samples (less than three) or insufficient data to compute statistic, or element not analyzed; <, less than minimum reporting level]

\begin{tabular}{|c|c|c|c|c|c|}
\hline Constituent & $\begin{array}{c}\text { Number of composite } \\
\text { samples }\end{array}$ & Maximum & Minimum & Mean & Median \\
\hline \multicolumn{6}{|c|}{$\begin{array}{l}\text { 461415112450801 - Clark Fork below Lost Creek, near Galen-Continued } \\
\text { Period of record for biological data: 1996-2017 }\end{array}$} \\
\hline \multicolumn{6}{|c|}{ Hydropsyche spp. } \\
\hline Arsenic & 5 & 14.5 & 7.0 & 11.1 & 12.0 \\
\hline Cadmium & 9 & 1.8 & 1.0 & 1.4 & 1.3 \\
\hline Copper & 9 & 153 & 45.1 & 101 & 103 \\
\hline Iron & 9 & 2,040 & 533 & 1,260 & 1,200 \\
\hline Lead & 9 & 20.5 & 4.1 & 10.2 & 8.7 \\
\hline Manganese & 9 & 2,800 & 775 & 1,440 & 1,230 \\
\hline Arsenic & 2 & 5.2 & 3.5 & 4.4 & -- \\
\hline Cadmium & 2 & 4.3 & 3.9 & 4.1 & -- \\
\hline Chromium & 2 & 1.1 & 1.0 & 1.0 & -- \\
\hline Copper & 2 & 93.1 & 73.7 & 83.4 & -- \\
\hline Iron & 2 & 346 & 324 & 335 & -- \\
\hline Lead & 2 & 5.9 & 4.8 & 5.4 & -- \\
\hline Manganese & 2 & 320 & 192 & 256 & -- \\
\hline Nickel & 2 & 0.3 & 0.3 & 0.3 & -- \\
\hline Zinc & 2 & 411 & 301 & 356 & -- \\
\hline \multicolumn{6}{|c|}{$\begin{array}{l}461559112443301 \text { - Clark Fork at county bridge, near Racetrack } \\
\text { Period of record for biological data: } 1996-2017\end{array}$} \\
\hline Copper & 3 & 101 & 81.0 & 90.9 & 90.9 \\
\hline Iron & 3 & 1,410 & 803 & 1,030 & 889 \\
\hline Lead & 3 & 13.2 & 9.1 & 10.5 & 9.1 \\
\hline Manganese & 3 & 3,140 & 1,430 & 2,350 & 2,480 \\
\hline Nickel & 3 & 6.4 & 1.4 & 3.2 & 1.9 \\
\hline Zinc & 3 & 572 & 243 & 358 & 260 \\
\hline
\end{tabular}


Table 23. Statistical summary of long-term biological data for the Clark Fork Basin, Montana, August 1986 through August 2017.Continued

[Reported concentrations are in micrograms per gram dry weight. Number of composite samples represents the total of all individual composite samples collected for every year that the constituent was analyzed. Values for a single sample are arbitrarily listed in the "Mean" column. Because Hydropsyche insects were not sorted to the species level during 1986-9, Hydropsyche species statistics for stations sampled during those years are based on the results of all Hydropsyche species combined. At some sites, statistics of the Hydropsyche morosa group are based on the combined results of two or more species. Insects collected during 1986-98 were depurated before analysis; depuration was discontinued in 1999. Arsenic was not analyzed until 2003; therefore, the number of samples may be small or zero for some taxa. spp., one or more similar species; --, indicates either too few samples (less than three) or insufficient data to compute statistic, or element not analyzed; <, less than minimum reporting level]

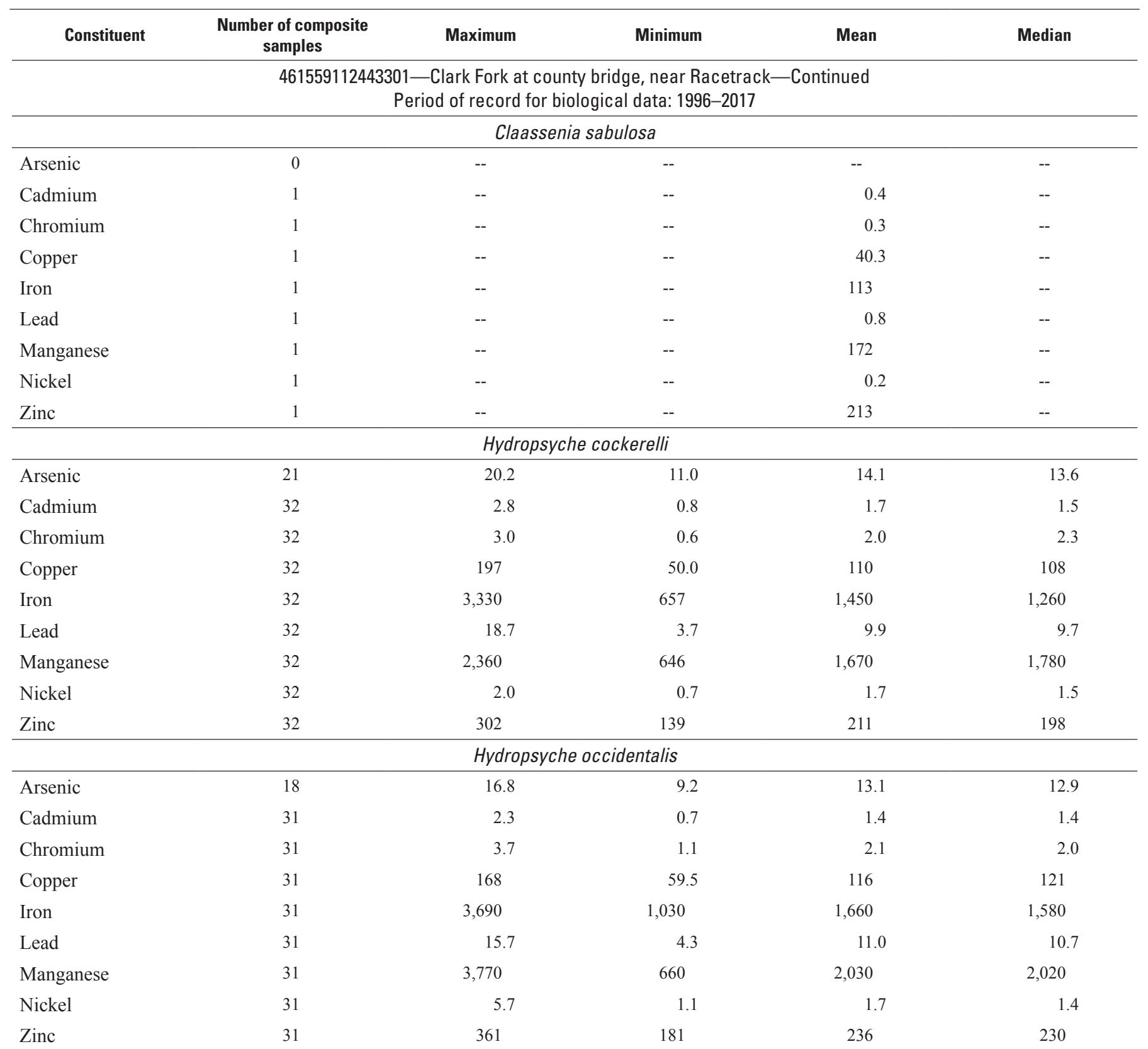


Table 23. Statistical summary of long-term biological data for the Clark Fork Basin, Montana, August 1986 through August 2017.Continued

[Reported concentrations are in micrograms per gram dry weight. Number of composite samples represents the total of all individual composite samples collected for every year that the constituent was analyzed. Values for a single sample are arbitrarily listed in the "Mean" column. Because Hydropsyche insects were not sorted to the species level during 1986-9, Hydropsyche species statistics for stations sampled during those years are based on the results of all Hydropsyche species combined. At some sites, statistics of the Hydropsyche morosa group are based on the combined results of two or more species. Insects collected during 1986-98 were depurated before analysis; depuration was discontinued in 1999. Arsenic was not analyzed until 2003; therefore, the number of samples may be small or zero for some taxa. spp., one or more similar species; --, indicates either too few samples (less than three) or insufficient data to compute statistic, or element not analyzed; <, less than minimum reporting level]

\begin{tabular}{|c|c|c|c|c|c|}
\hline Constituent & $\begin{array}{c}\text { Number of composite } \\
\text { samples }\end{array}$ & Maximum & Minimum & Mean & Median \\
\hline \multicolumn{6}{|c|}{$\begin{array}{l}461559112443301 \text {-Clark Fork at county bridge, near Racetrack-Continued } \\
\text { Period of record for biological data: 1996-2017 }\end{array}$} \\
\hline \multicolumn{6}{|c|}{ Hydropsyche spp. } \\
\hline Arsenic & 6 & 12.8 & 5.7 & 9.6 & 9.8 \\
\hline Cadmium & 8 & 2.4 & 1.0 & 1.6 & 1.5 \\
\hline Copper & 8 & 144 & 68.1 & 97 & 84.0 \\
\hline Iron & 8 & 1,880 & 787 & 1,220 & 1,170 \\
\hline Lead & 8 & 15.0 & 5.7 & 8.8 & 7.1 \\
\hline Manganese & 8 & 2,370 & 886 & 1,320 & 1,150 \\
\hline
\end{tabular}

461903112440701 - Clark Fork at Dempsey Creek diversion, near Racetrack Period of record for biological data: 1996-2017

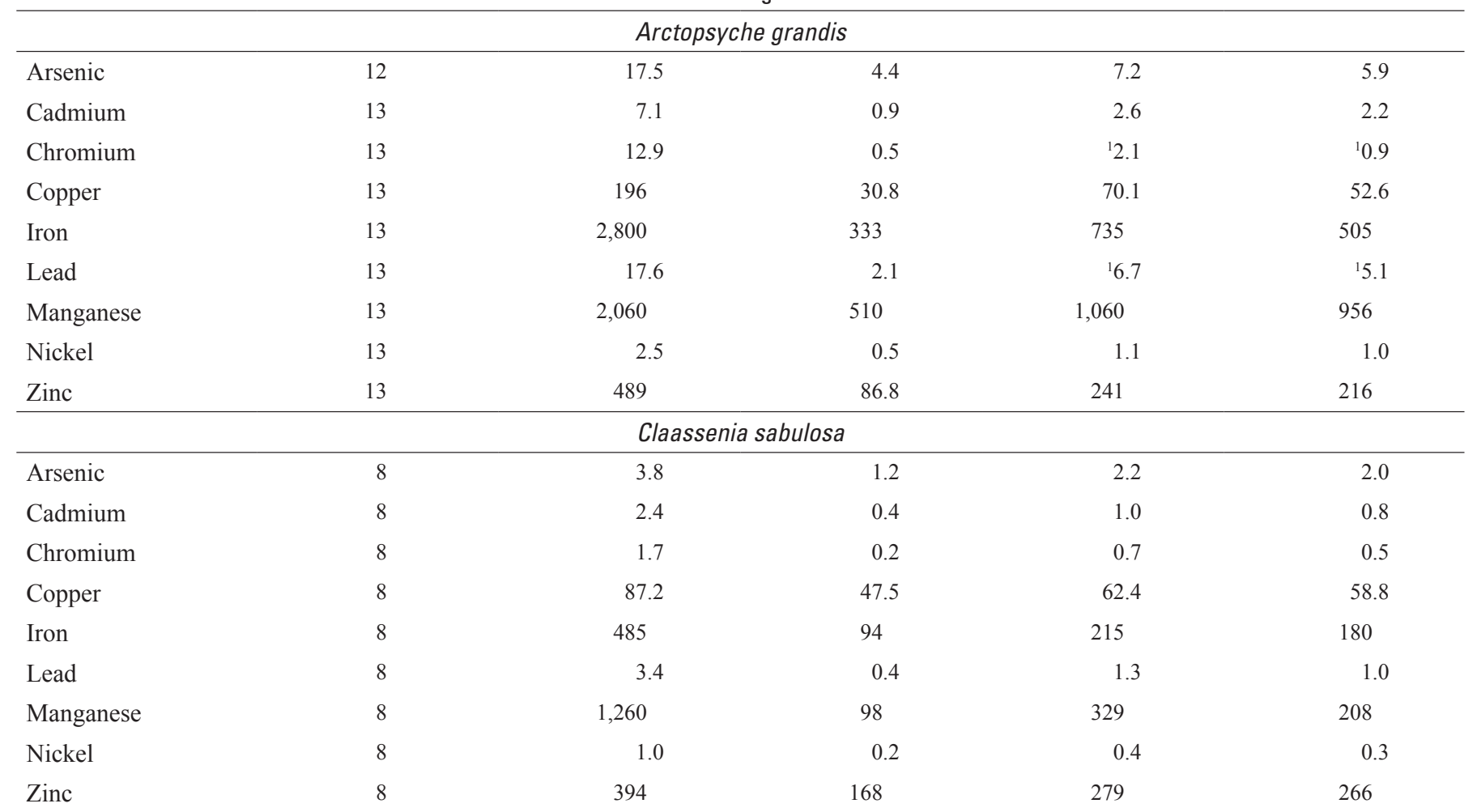


Table 23. Statistical summary of long-term biological data for the Clark Fork Basin, Montana, August 1986 through August 2017.Continued

[Reported concentrations are in micrograms per gram dry weight. Number of composite samples represents the total of all individual composite samples collected for every year that the constituent was analyzed. Values for a single sample are arbitrarily listed in the "Mean" column. Because Hydropsyche insects were not sorted to the species level during 1986-9, Hydropsyche species statistics for stations sampled during those years are based on the results of all Hydropsyche species combined. At some sites, statistics of the Hydropsyche morosa group are based on the combined results of two or more species. Insects collected during 1986-98 were depurated before analysis; depuration was discontinued in 1999. Arsenic was not analyzed until 2003; therefore, the number of samples may be small or zero for some taxa. spp., one or more similar species; --, indicates either too few samples (less than three) or insufficient data to compute statistic, or element not analyzed; <, less than minimum reporting level]

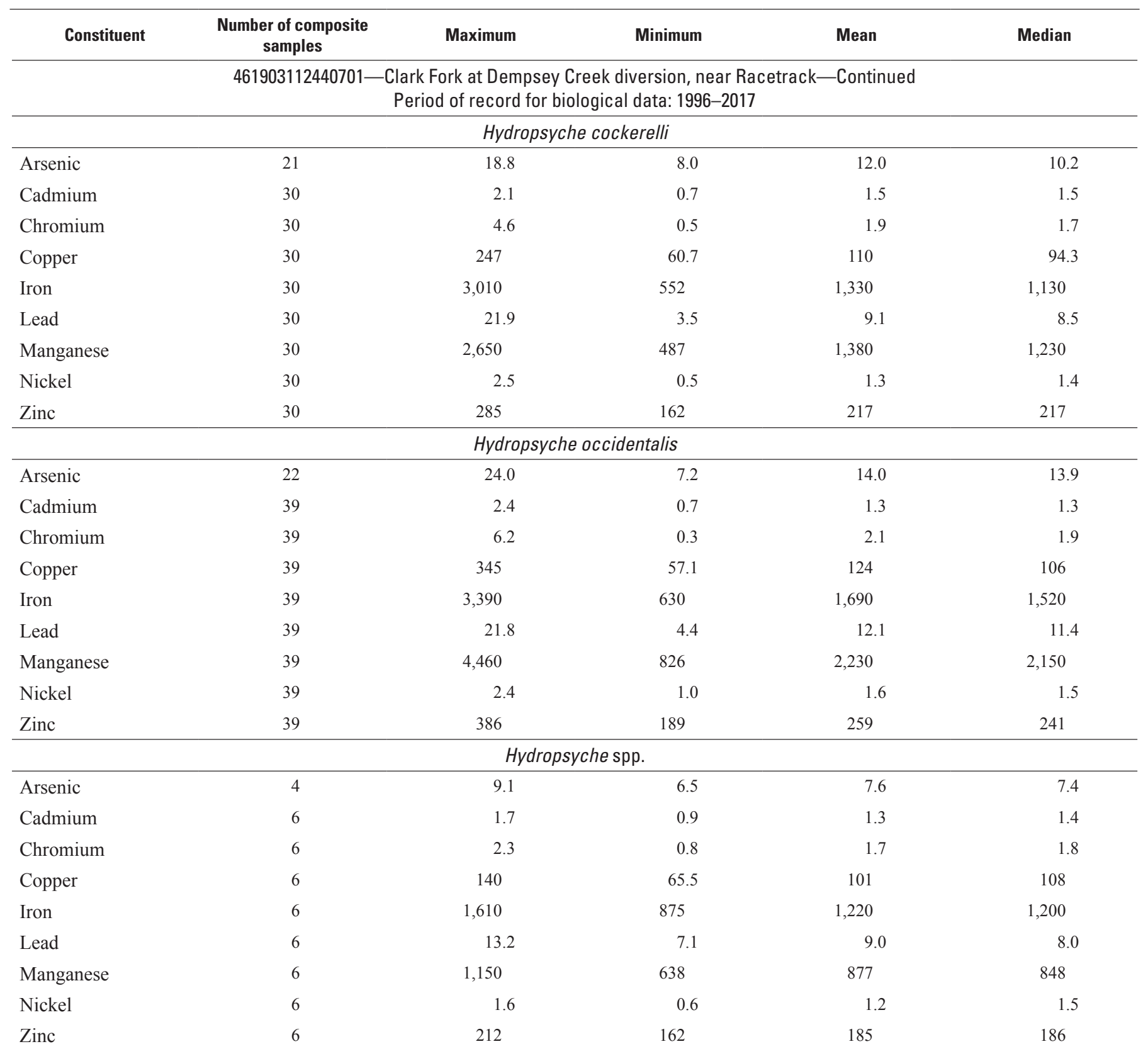


Table 23. Statistical summary of long-term biological data for the Clark Fork Basin, Montana, August 1986 through August 2017.Continued

[Reported concentrations are in micrograms per gram dry weight. Number of composite samples represents the total of all individual composite samples collected for every year that the constituent was analyzed. Values for a single sample are arbitrarily listed in the "Mean" column. Because Hydropsyche insects were not sorted to the species level during 1986-9, Hydropsyche species statistics for stations sampled during those years are based on the results of all Hydropsyche species combined. At some sites, statistics of the Hydropsyche morosa group are based on the combined results of two or more species. Insects collected during 1986-98 were depurated before analysis; depuration was discontinued in 1999. Arsenic was not analyzed until 2003; therefore, the number of samples may be small or zero for some taxa. spp., one or more similar species; --, indicates either too few samples (less than three) or insufficient data to compute statistic, or element not analyzed; <, less than minimum reporting level]

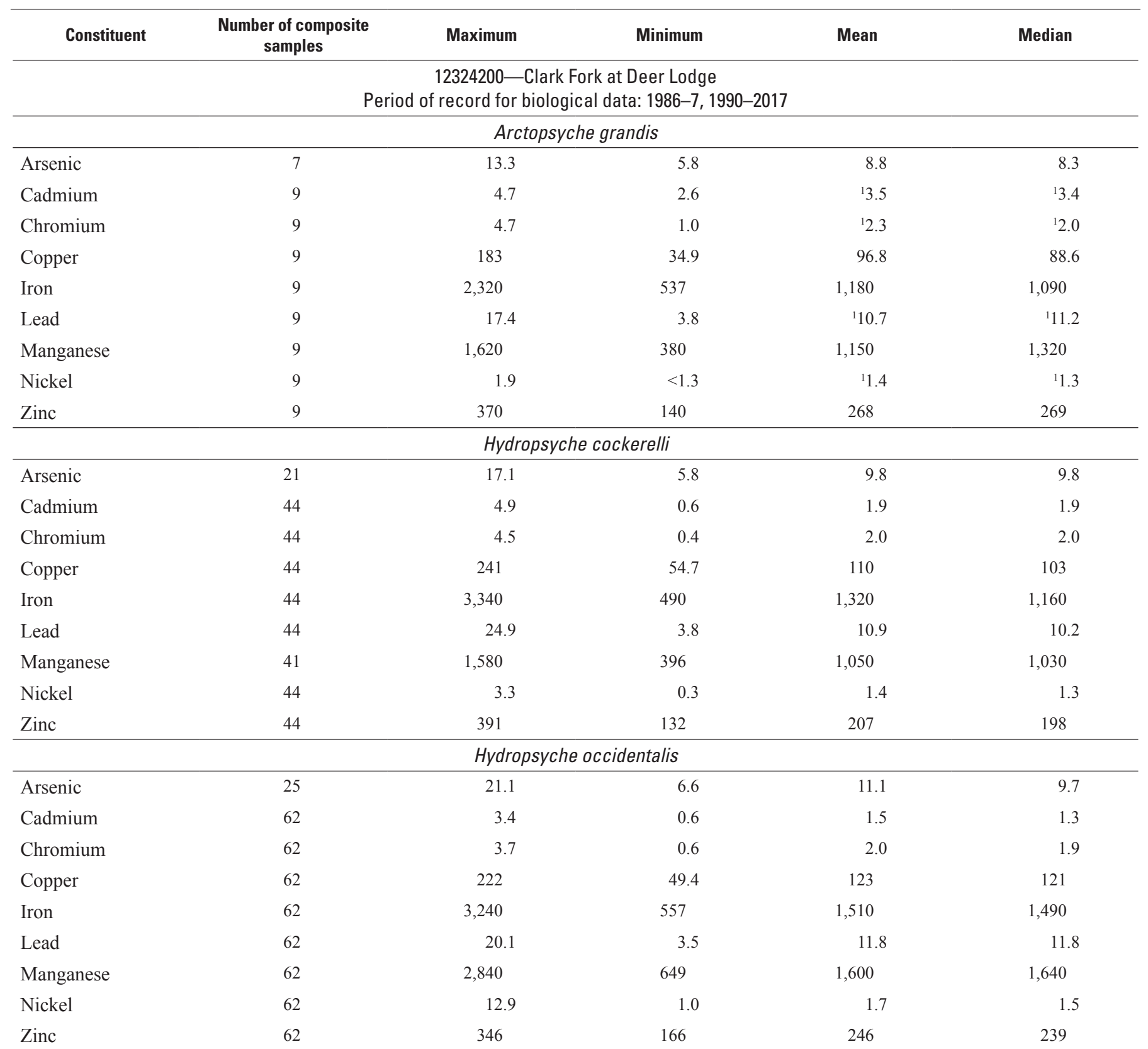


Table 23. Statistical summary of long-term biological data for the Clark Fork Basin, Montana, August 1986 through August 2017.Continued

[Reported concentrations are in micrograms per gram dry weight. Number of composite samples represents the total of all individual composite samples collected for every year that the constituent was analyzed. Values for a single sample are arbitrarily listed in the "Mean" column. Because Hydropsyche insects were not sorted to the species level during 1986-9, Hydropsyche species statistics for stations sampled during those years are based on the results of all Hydropsyche species combined. At some sites, statistics of the Hydropsyche morosa group are based on the combined results of two or more species. Insects collected during 1986-98 were depurated before analysis; depuration was discontinued in 1999. Arsenic was not analyzed until 2003; therefore, the number of samples may be small or zero for some taxa. spp., one or more similar species; --, indicates either too few samples (less than three) or insufficient data to compute statistic, or element not analyzed; <, less than minimum reporting level]

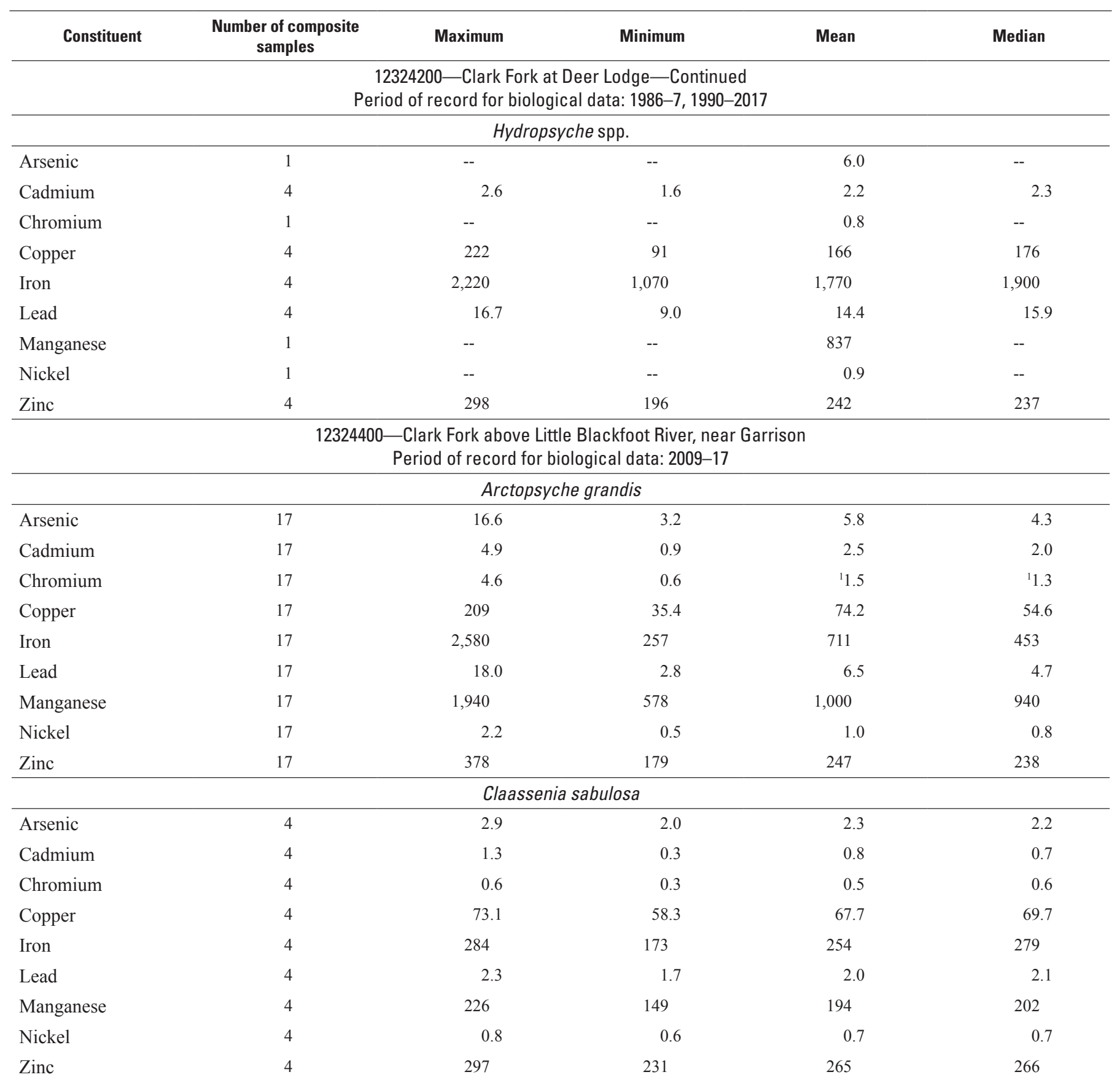


Table 23. Statistical summary of long-term biological data for the Clark Fork Basin, Montana, August 1986 through August 2017.Continued

[Reported concentrations are in micrograms per gram dry weight. Number of composite samples represents the total of all individual composite samples collected for every year that the constituent was analyzed. Values for a single sample are arbitrarily listed in the "Mean" column. Because Hydropsyche insects were not sorted to the species level during 1986-9, Hydropsyche species statistics for stations sampled during those years are based on the results of all Hydropsyche species combined. At some sites, statistics of the Hydropsyche morosa group are based on the combined results of two or more species. Insects collected during 1986-98 were depurated before analysis; depuration was discontinued in 1999. Arsenic was not analyzed until 2003; therefore, the number of samples may be small or zero for some taxa. spp., one or more similar species; --, indicates either too few samples (less than three) or insufficient data to compute statistic, or element not analyzed; <, less than minimum reporting level]

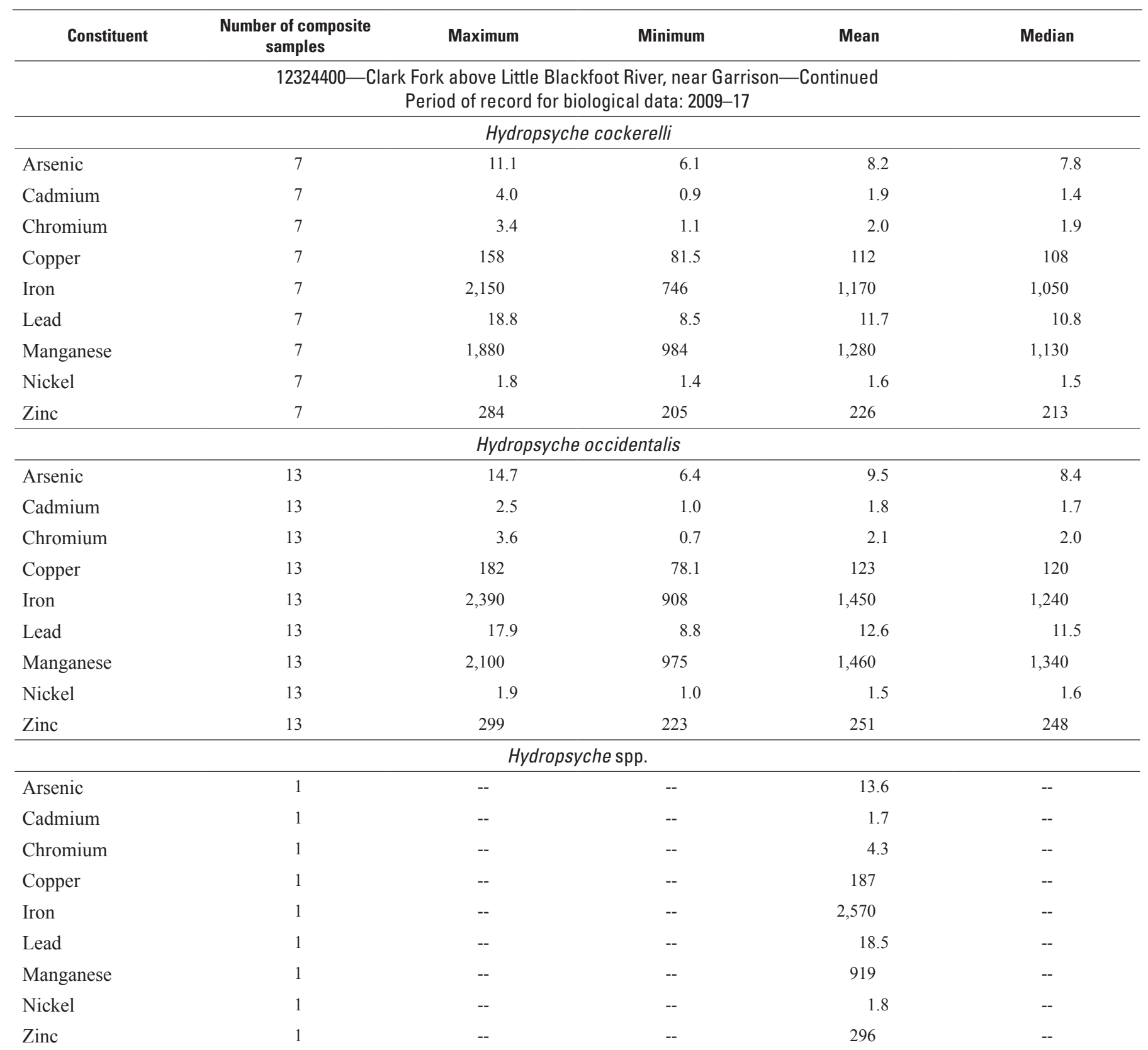


Table 23. Statistical summary of long-term biological data for the Clark Fork Basin, Montana, August 1986 through August 2017.Continued

[Reported concentrations are in micrograms per gram dry weight. Number of composite samples represents the total of all individual composite samples collected for every year that the constituent was analyzed. Values for a single sample are arbitrarily listed in the "Mean" column. Because Hydropsyche insects were not sorted to the species level during 1986-9, Hydropsyche species statistics for stations sampled during those years are based on the results of all Hydropsyche species combined. At some sites, statistics of the Hydropsyche morosa group are based on the combined results of two or more species. Insects collected during 1986-98 were depurated before analysis; depuration was discontinued in 1999. Arsenic was not analyzed until 2003; therefore, the number of samples may be small or zero for some taxa. spp., one or more similar species; --, indicates either too few samples (less than three) or insufficient data to compute statistic, or element not analyzed; <, less than minimum reporting level]

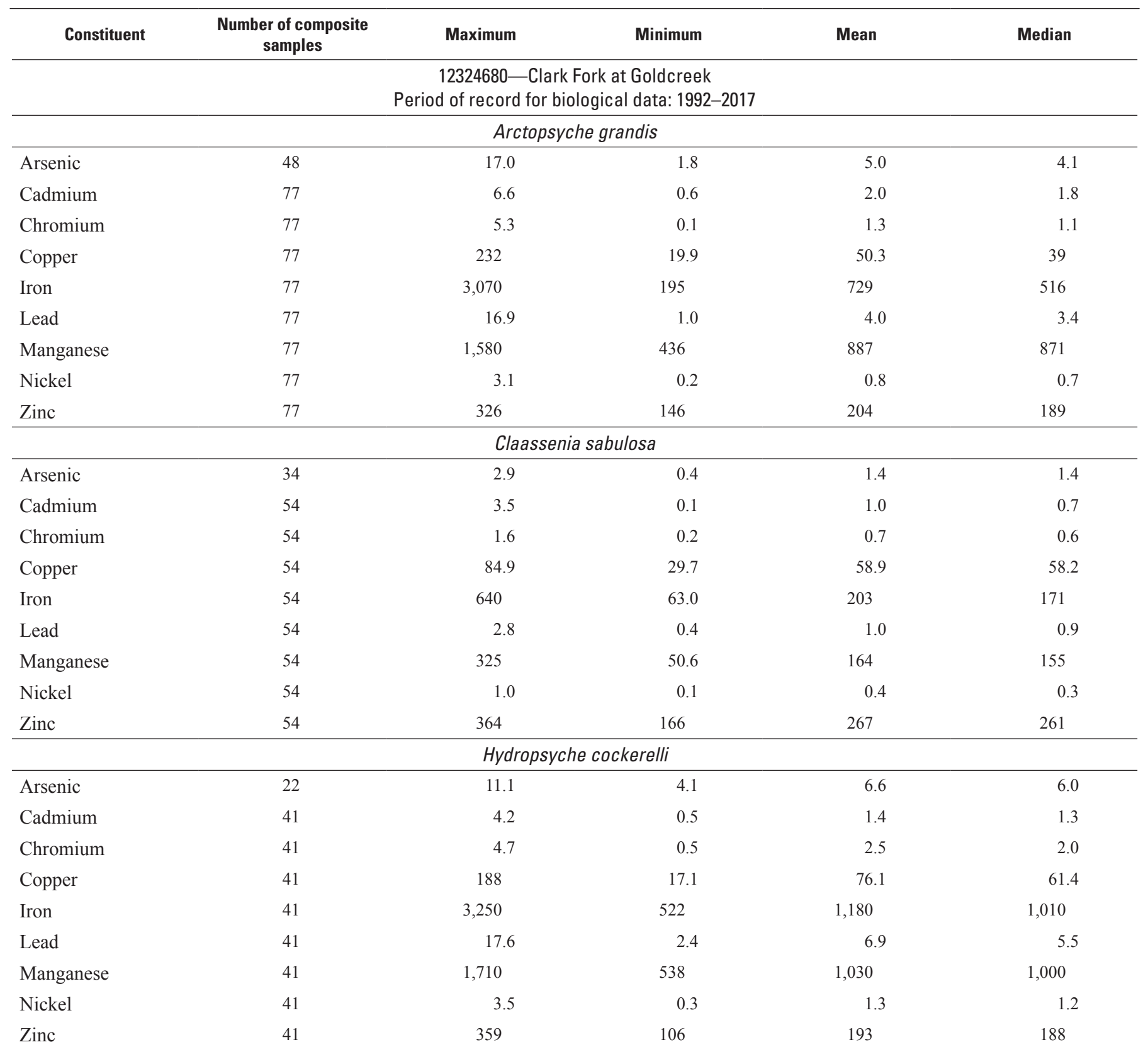


Table 23. Statistical summary of long-term biological data for the Clark Fork Basin, Montana, August 1986 through August 2017.Continued

[Reported concentrations are in micrograms per gram dry weight. Number of composite samples represents the total of all individual composite samples collected for every year that the constituent was analyzed. Values for a single sample are arbitrarily listed in the "Mean" column. Because Hydropsyche insects were not sorted to the species level during 1986-9, Hydropsyche species statistics for stations sampled during those years are based on the results of all Hydropsyche species combined. At some sites, statistics of the Hydropsyche morosa group are based on the combined results of two or more species. Insects collected during 1986-98 were depurated before analysis; depuration was discontinued in 1999. Arsenic was not analyzed until 2003; therefore, the number of samples may be small or zero for some taxa. spp., one or more similar species; --, indicates either too few samples (less than three) or insufficient data to compute statistic, or element not analyzed; <, less than minimum reporting level]

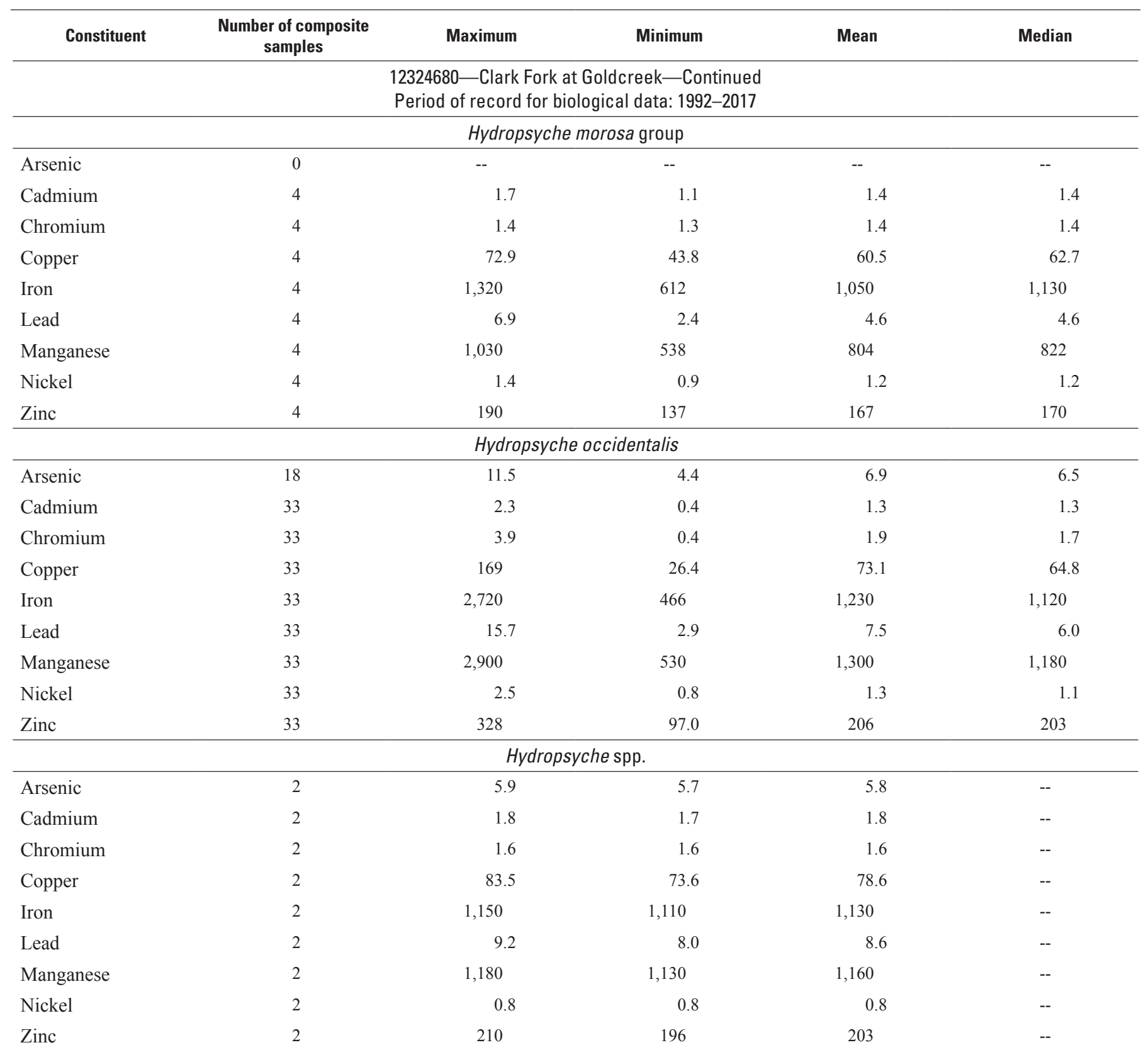


Table 23. Statistical summary of long-term biological data for the Clark Fork Basin, Montana, August 1986 through August 2017.Continued

[Reported concentrations are in micrograms per gram dry weight. Number of composite samples represents the total of all individual composite samples collected for every year that the constituent was analyzed. Values for a single sample are arbitrarily listed in the "Mean" column. Because Hydropsyche insects were not sorted to the species level during 1986-9, Hydropsyche species statistics for stations sampled during those years are based on the results of all Hydropsyche species combined. At some sites, statistics of the Hydropsyche morosa group are based on the combined results of two or more species. Insects collected during 1986-98 were depurated before analysis; depuration was discontinued in 1999. Arsenic was not analyzed until 2003; therefore, the number of samples may be small or zero for some taxa. spp., one or more similar species; --, indicates either too few samples (less than three) or insufficient data to compute statistic, or element not analyzed; <, less than minimum reporting level]

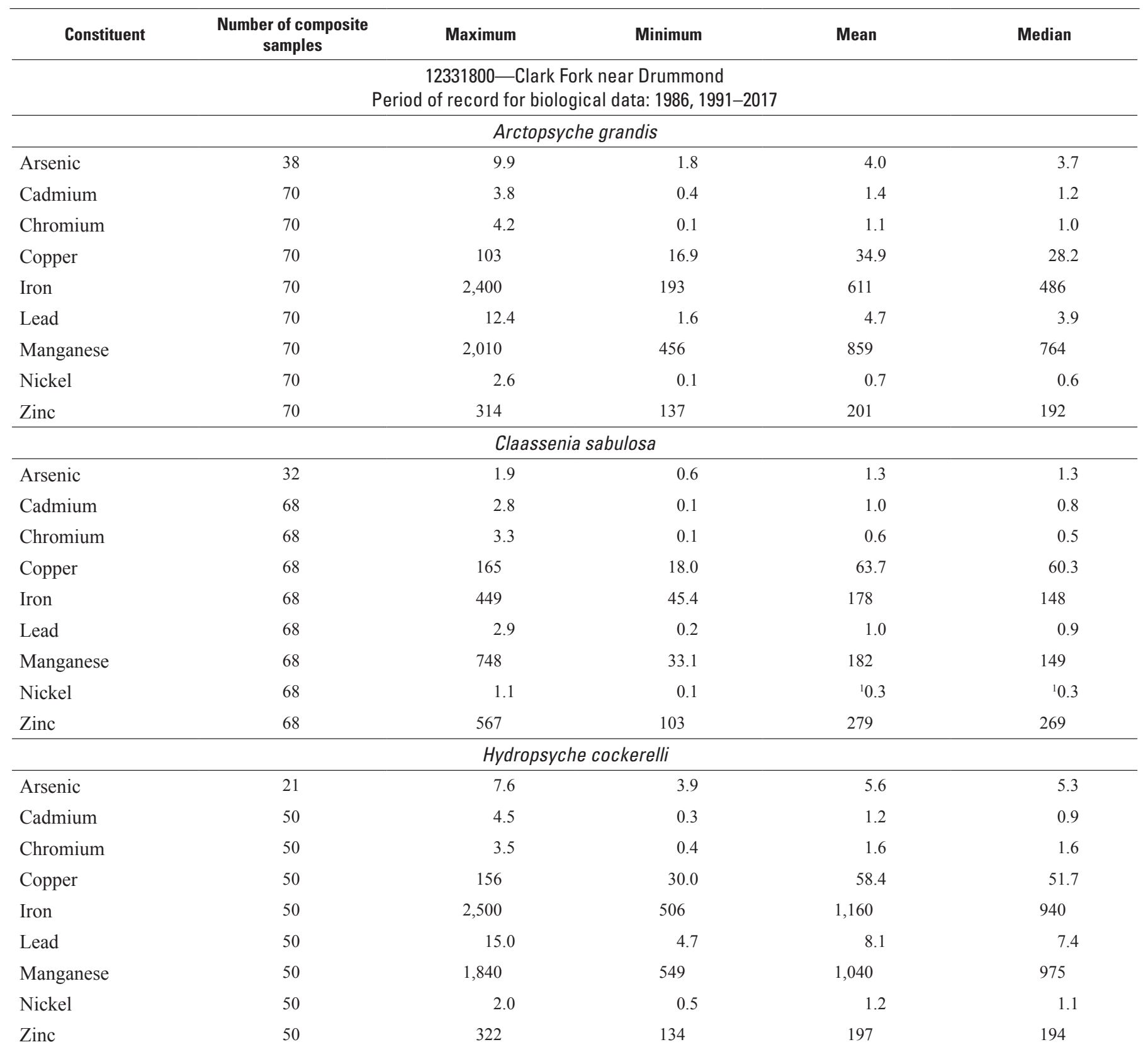


Table 23. Statistical summary of long-term biological data for the Clark Fork Basin, Montana, August 1986 through August 2017.Continued

[Reported concentrations are in micrograms per gram dry weight. Number of composite samples represents the total of all individual composite samples collected for every year that the constituent was analyzed. Values for a single sample are arbitrarily listed in the "Mean" column. Because Hydropsyche insects were not sorted to the species level during 1986-9, Hydropsyche species statistics for stations sampled during those years are based on the results of all Hydropsyche species combined. At some sites, statistics of the Hydropsyche morosa group are based on the combined results of two or more species. Insects collected during 1986-98 were depurated before analysis; depuration was discontinued in 1999. Arsenic was not analyzed until 2003; therefore, the number of samples may be small or zero for some taxa. spp., one or more similar species; --, indicates either too few samples (less than three) or insufficient data to compute statistic, or element not analyzed; <, less than minimum reporting level]

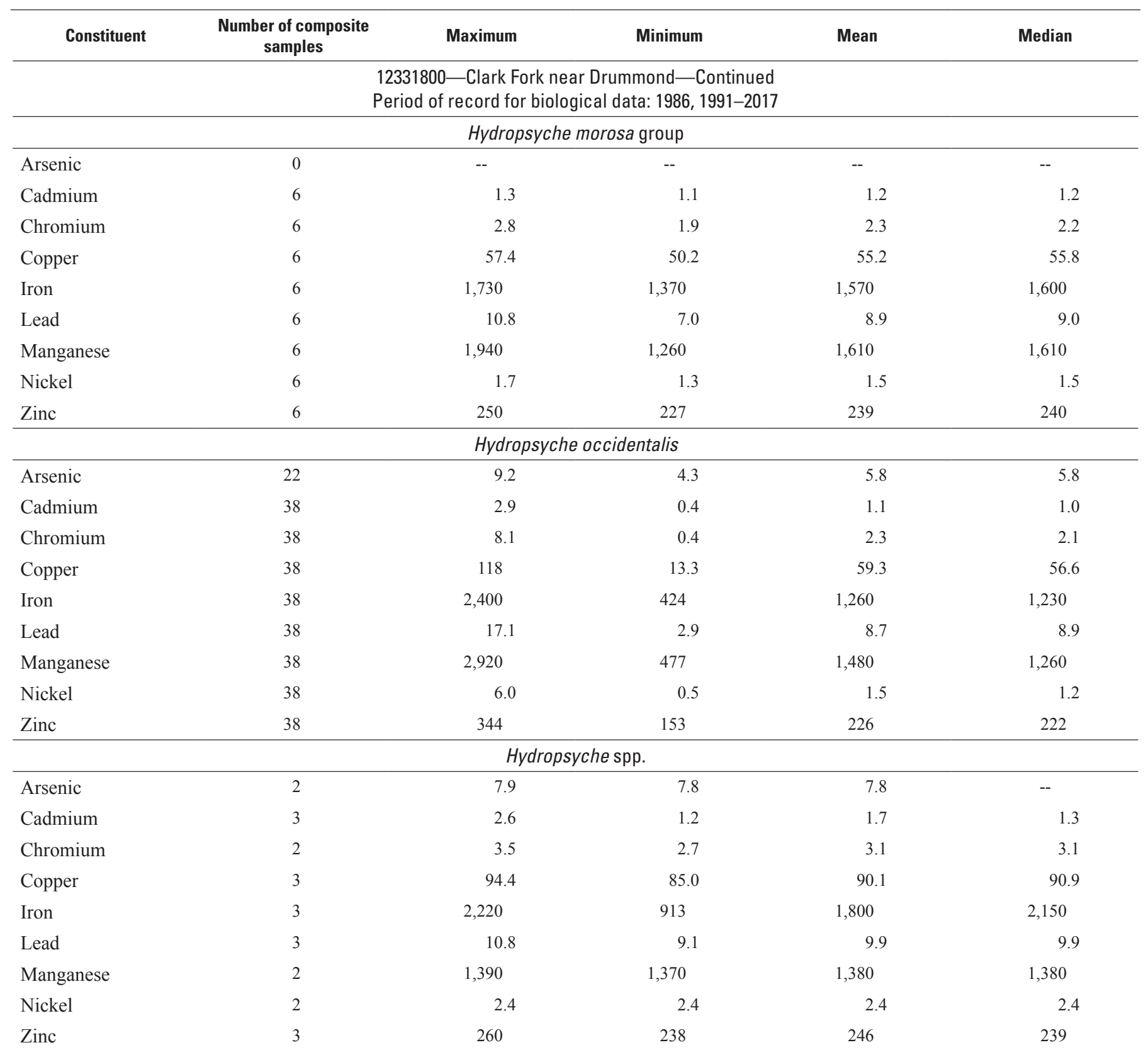


Table 23. Statistical summary of long-term biological data for the Clark Fork Basin, Montana, August 1986 through August 2017.Continued

[Reported concentrations are in micrograms per gram dry weight. Number of composite samples represents the total of all individual composite samples collected for every year that the constituent was analyzed. Values for a single sample are arbitrarily listed in the "Mean" column. Because Hydropsyche insects were not sorted to the species level during 1986-9, Hydropsyche species statistics for stations sampled during those years are based on the results of all Hydropsyche species combined. At some sites, statistics of the Hydropsyche morosa group are based on the combined results of two or more species. Insects collected during 1986-98 were depurated before analysis; depuration was discontinued in 1999. Arsenic was not analyzed until 2003; therefore, the number of samples may be small or zero for some taxa. spp., one or more similar species; --, indicates either too few samples (less than three) or insufficient data to compute statistic, or element not analyzed; <, less than minimum reporting level]

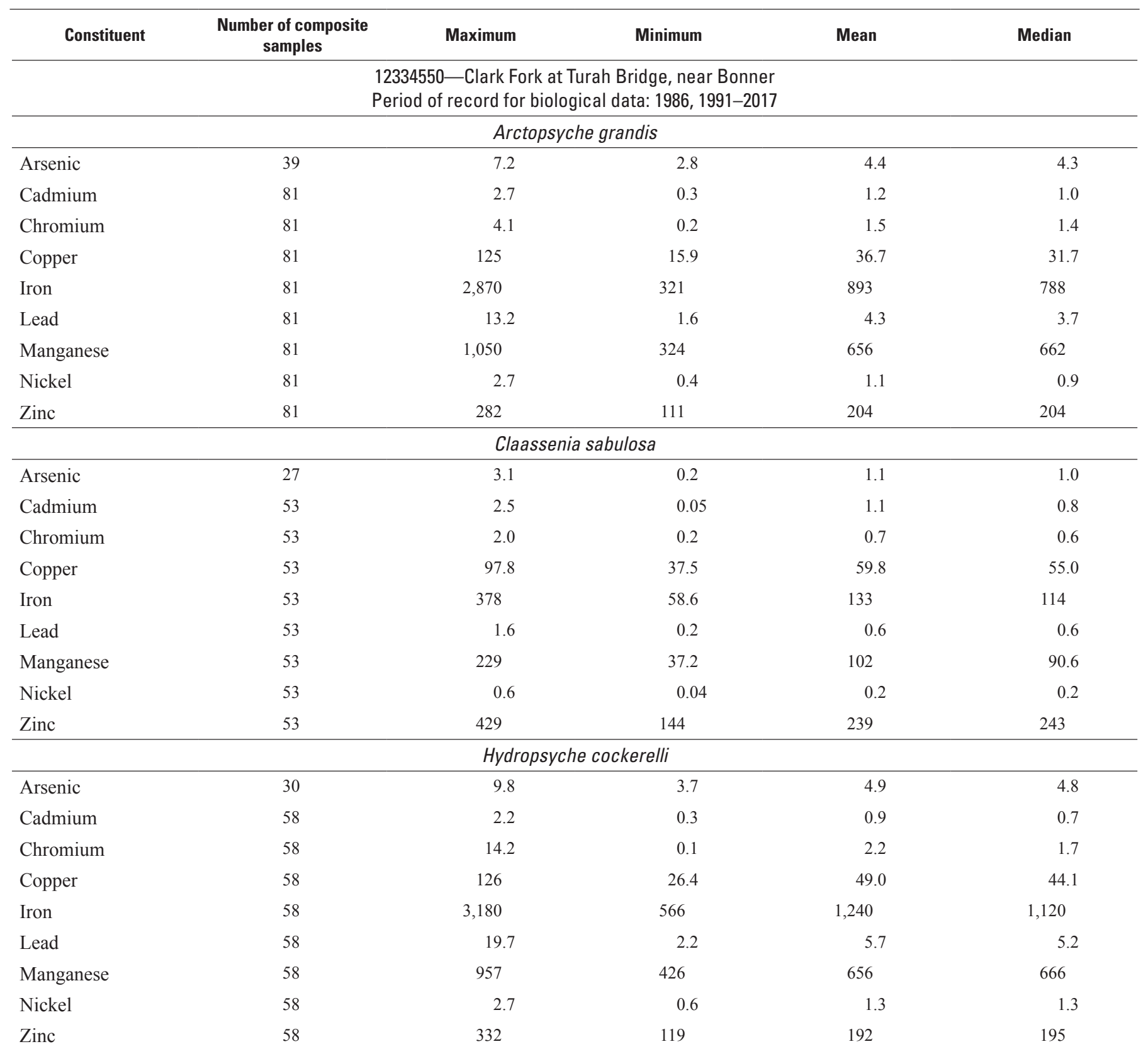


Table 23. Statistical summary of long-term biological data for the Clark Fork Basin, Montana, August 1986 through August 2017.Continued

[Reported concentrations are in micrograms per gram dry weight. Number of composite samples represents the total of all individual composite samples collected for every year that the constituent was analyzed. Values for a single sample are arbitrarily listed in the "Mean" column. Because Hydropsyche insects were not sorted to the species level during 1986-9, Hydropsyche species statistics for stations sampled during those years are based on the results of all Hydropsyche species combined. At some sites, statistics of the Hydropsyche morosa group are based on the combined results of two or more species. Insects collected during 1986-98 were depurated before analysis; depuration was discontinued in 1999. Arsenic was not analyzed until 2003; therefore, the number of samples may be small or zero for some taxa. spp., one or more similar species; --, indicates either too few samples (less than three) or insufficient data to compute statistic, or element not analyzed; <, less than minimum reporting level]

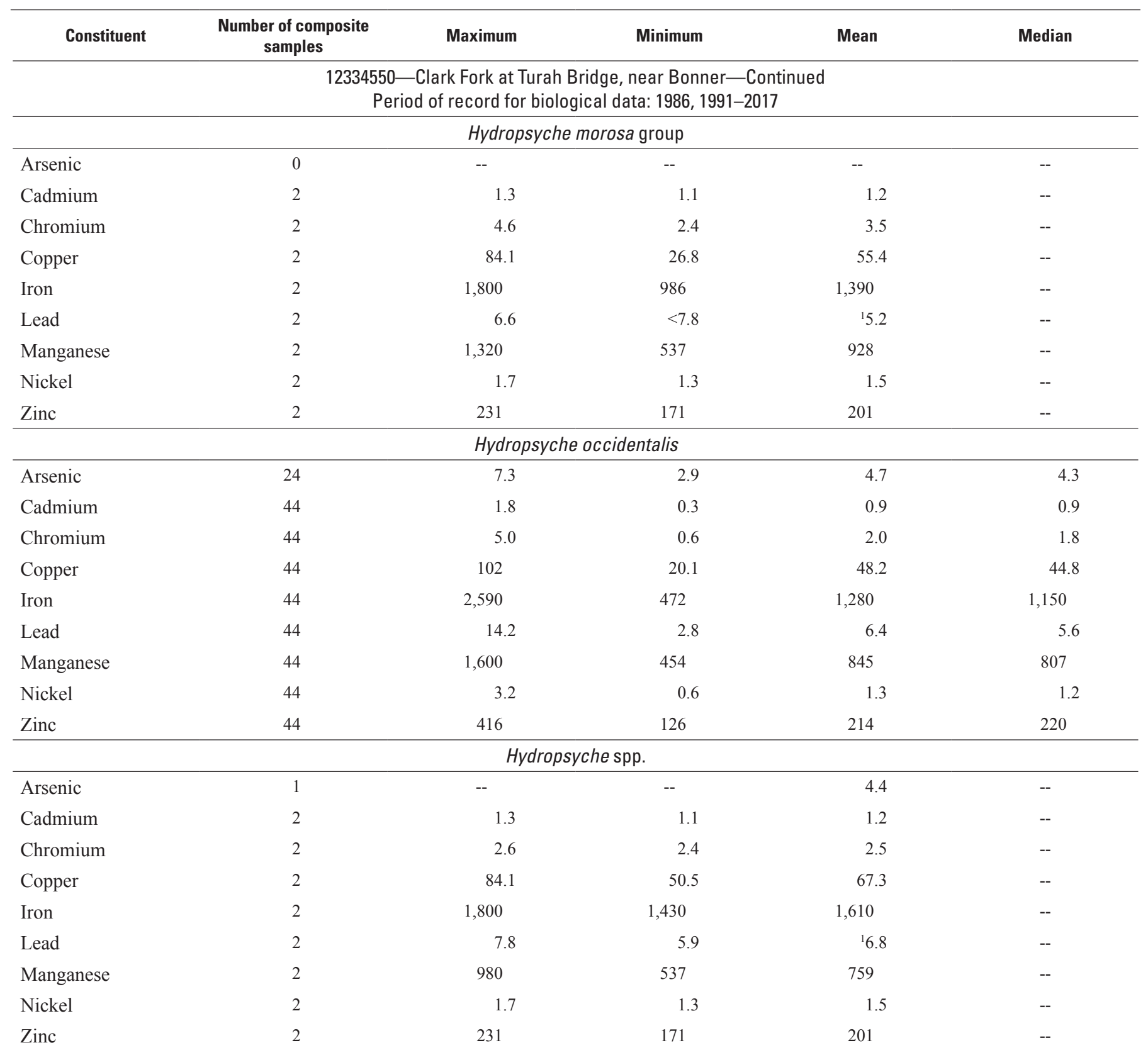


Table 23. Statistical summary of long-term biological data for the Clark Fork Basin, Montana, August 1986 through August 2017.Continued

[Reported concentrations are in micrograms per gram dry weight. Number of composite samples represents the total of all individual composite samples collected for every year that the constituent was analyzed. Values for a single sample are arbitrarily listed in the "Mean" column. Because Hydropsyche insects were not sorted to the species level during 1986-9, Hydropsyche species statistics for stations sampled during those years are based on the results of all Hydropsyche species combined. At some sites, statistics of the Hydropsyche morosa group are based on the combined results of two or more species. Insects collected during 1986-98 were depurated before analysis; depuration was discontinued in 1999. Arsenic was not analyzed until 2003; therefore, the number of samples may be small or zero for some taxa. spp., one or more similar species; --, indicates either too few samples (less than three) or insufficient data to compute statistic, or element not analyzed; <, less than minimum reporting level]

\begin{tabular}{|c|c|c|c|c|c|}
\hline Constituent & $\begin{array}{l}\text { Number of composite } \\
\text { samples }\end{array}$ & Maximum & Minimum & Mean & Median \\
\hline \multicolumn{6}{|c|}{$\begin{array}{l}\qquad 12340000 \text {-Blackfoot River near Bonner } \\
\text { Period of record for biological data: 1986-7, 1991, 1993, 1996, 1998, 2000, 2003, 2006-17 }\end{array}$} \\
\hline \multicolumn{6}{|c|}{ Arctopsyche grandis } \\
\hline Arsenic & 17 & 4.6 & 1.6 & 2.7 & 2.6 \\
\hline Cadmium & 27 & 0.5 & 0.1 & 0.3 & 0.2 \\
\hline Copper & 27 & 19.3 & 9.9 & 13.7 & 12.8 \\
\hline Iron & 27 & 1,880 & 108 & 763 & 765 \\
\hline Lead & 27 & 2.3 & 0.5 & 1.1 & 0.9 \\
\hline Manganese & 22 & 633 & 286 & 446 & 422 \\
\hline \multicolumn{6}{|c|}{ Claassenia sabulosa } \\
\hline Arsenic & 13 & 3.0 & 0.1 & 1.0 & 0.7 \\
\hline Cadmium & 24 & 0.2 & 0.1 & 0.1 & 0.2 \\
\hline Chromium & 19 & 5.2 & 0.3 & 1.0 & 0.7 \\
\hline Copper & 24 & 88.5 & 19.0 & 43.3 & 44.0 \\
\hline Iron & 24 & 317 & 46.2 & 144 & 137 \\
\hline Lead & 24 & 0.8 & 0.1 & 0.3 & 0.2 \\
\hline Manganese & 19 & 133 & 26.3 & 79.3 & 73.4 \\
\hline Nickel & 19 & 1.1 & 0.1 & 0.3 & 0.3 \\
\hline Zinc & 24 & 399 & 117 & 229 & 207 \\
\hline Lead & 12 & 2.6 & 1.5 & 2.0 & 1.9 \\
\hline Manganese & 12 & 814 & 409 & 556 & 542 \\
\hline Nickel & 12 & 4.5 & 1.4 & 2.0 & 1.8 \\
\hline Zinc & 12 & 165 & 132 & 148 & 148 \\
\hline
\end{tabular}


Table 23. Statistical summary of long-term biological data for the Clark Fork Basin, Montana, August 1986 through August 2017.Continued

[Reported concentrations are in micrograms per gram dry weight. Number of composite samples represents the total of all individual composite samples collected for every year that the constituent was analyzed. Values for a single sample are arbitrarily listed in the "Mean" column. Because Hydropsyche insects were not sorted to the species level during 1986-9, Hydropsyche species statistics for stations sampled during those years are based on the results of all Hydropsyche species combined. At some sites, statistics of the Hydropsyche morosa group are based on the combined results of two or more species. Insects collected during 1986-98 were depurated before analysis; depuration was discontinued in 1999. Arsenic was not analyzed until 2003; therefore, the number of samples may be small or zero for some taxa. spp., one or more similar species; --, indicates either too few samples (less than three) or insufficient data to compute statistic, or element not analyzed; <, less than minimum reporting level]

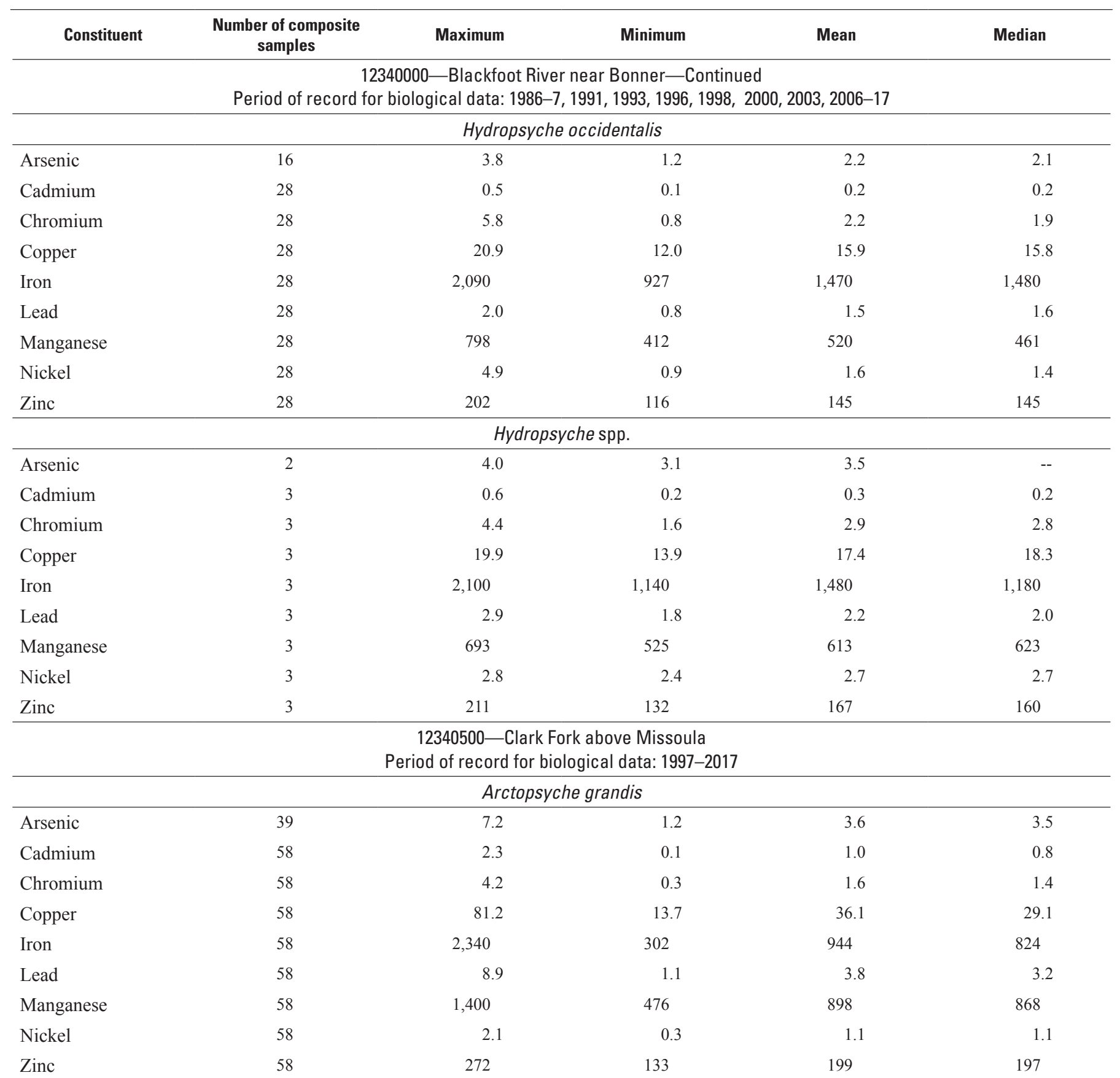


Table 23. Statistical summary of long-term biological data for the Clark Fork Basin, Montana, August 1986 through August 2017.Continued

[Reported concentrations are in micrograms per gram dry weight. Number of composite samples represents the total of all individual composite samples collected for every year that the constituent was analyzed. Values for a single sample are arbitrarily listed in the "Mean" column. Because Hydropsyche insects were not sorted to the species level during 1986-9, Hydropsyche species statistics for stations sampled during those years are based on the results of all Hydropsyche species combined. At some sites, statistics of the Hydropsyche morosa group are based on the combined results of two or more species. Insects collected during 1986-98 were depurated before analysis; depuration was discontinued in 1999. Arsenic was not analyzed until 2003; therefore, the number of samples may be small or zero for some taxa. spp., one or more similar species; --, indicates either too few samples (less than three) or insufficient data to compute statistic, or element not analyzed; <, less than minimum reporting level]

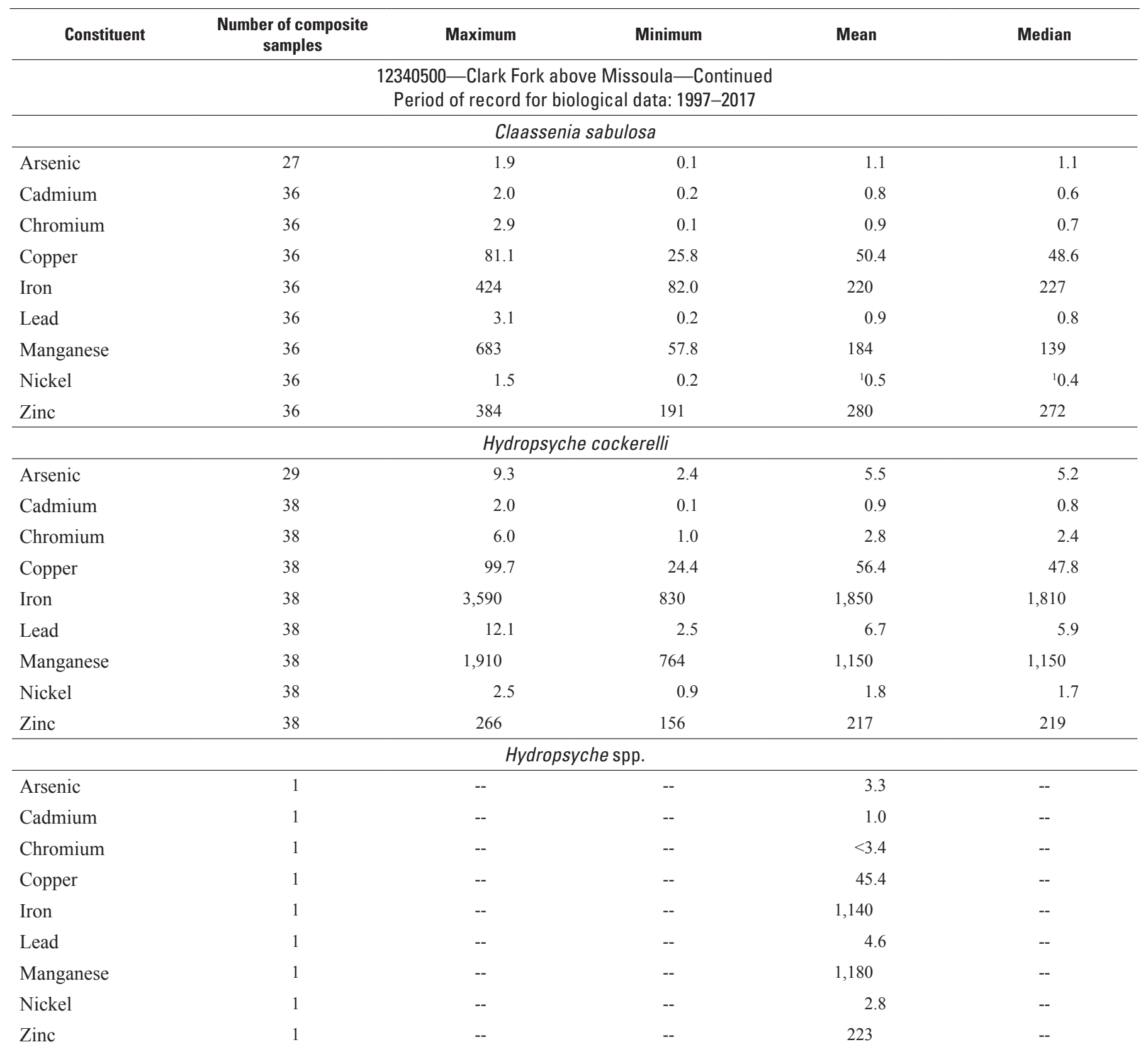


Table 23. Statistical summary of long-term biological data for the Clark Fork Basin, Montana, August 1986 through August 2017.Continued

[Reported concentrations are in micrograms per gram dry weight. Number of composite samples represents the total of all individual composite samples collected for every year that the constituent was analyzed. Values for a single sample are arbitrarily listed in the "Mean" column. Because Hydropsyche insects were not sorted to the species level during 1986-9, Hydropsyche species statistics for stations sampled during those years are based on the results of all Hydropsyche species combined. At some sites, statistics of the Hydropsyche morosa group are based on the combined results of two or more species. Insects collected during 1986-98 were depurated before analysis; depuration was discontinued in 1999. Arsenic was not analyzed until 2003; therefore, the number of samples may be small or zero for some taxa. spp., one or more similar species; --, indicates either too few samples (less than three) or insufficient data to compute statistic, or element not analyzed; <, less than minimum reporting level]

\begin{tabular}{|c|c|c|c|c|c|}
\hline Constituent & $\begin{array}{c}\text { Number of composite } \\
\text { samples }\end{array}$ & Maximum & Minimum & Mean & Median \\
\hline \multicolumn{6}{|c|}{$\begin{array}{l}12340500 \text { - Clark Fork above Missoula-Continued } \\
\text { Period of record for biological data: 1997-2017 }\end{array}$} \\
\hline \multicolumn{6}{|c|}{ Hydropsyche occidentalis } \\
\hline Arsenic & 14 & 7.4 & 2.2 & 5.0 & 5.1 \\
\hline Cadmium & 20 & 1.5 & 0.4 & 0.8 & 0.7 \\
\hline Copper & 20 & 80.7 & 25.3 & 51.6 & 57.3 \\
\hline Iron & 20 & 2,540 & 690 & 1,820 & 1,990 \\
\hline Lead & 20 & 11.4 & 2.1 & 6.5 & 6.3 \\
\hline Manganese & 20 & 2,470 & 717 & 1,510 & 1,560 \\
\hline
\end{tabular}

\footnotetext{
${ }^{1}$ Values determined by substituting one-half of the minimum reporting level for censored $(<)$ values when both uncensored and censored values were used in
} determining the mean and median. 
For more information about this publication, contact:

Director, USGS Wyoming-Montana Water Science Center 3162 Bozeman Avenue

Helena, MT 59601

406-457-5900

For additional information, visit: https://www.usgs.gov/centers/wy-mt-water/

Publishing support provided by the

Rolla Publishing Service Center 


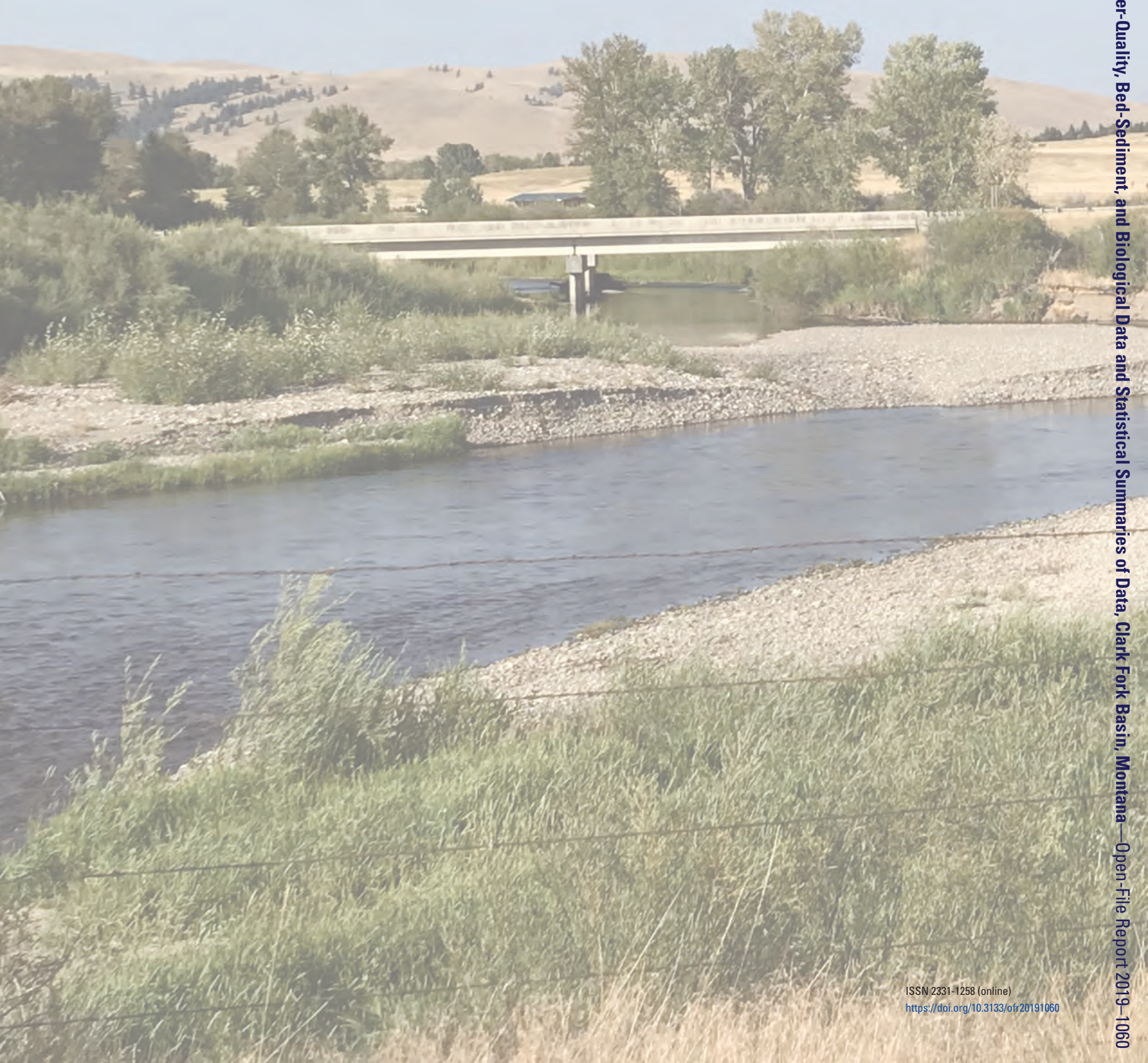

